UNIVERSIDADE DE SÃO PAULO

FACULDADE DE MEDICINA DE RIBEIRÃO PRETO

PROGRAMA DE PÓS-GRADUAÇÃO EM FARMACOLOGIA

Flávia Viana Santa-Cecília

\title{
Papel dos receptores intracelulares NOD1 e NOD2 na gênese da dor neuropática
}




\section{Flávia Viana Santa-Cecília}

\section{Papel dos receptores intracelulares NOD1 e NOD2 na gênese da dor neuropática}

Tese apresentada ao programa de Pósgraduação do Departamento de Farmacologia da Faculdade de Medicina de Ribeirão Preto da Universidade de São Paulo para a obtenção do título de Doutor em Ciências.

Área de Concentração: Farmacologia

Orientador: Prof. Dr. Thiago Mattar Cunha

Versão corrigida. A versão original encontra-se disponível tanto na Biblioteca da Unidade que aloja o Programa, quanto na Biblioteca Digital de Teses e Dissertações da USP (BDTD)

RIBEIRÃO PRETO 
Autorizo a reprodução e divulgação total ou parcial deste trabalho, por quaisquer meios convencionais ou eletrônicos, para fins de estudo e pesquisa, desde que citada a fonte.

Ficha Catalográfica

Santa-Cecília, Flávia Viana

Papel dos receptores intracelulares NOD1 e NOD2 na gênese da dor neuropática. Ribeirão Preto, 2015.

204 p.

Tese de doutorado, apresentada à Faculdade de Medicina de Ribeirão Preto/USP. Área de concentração: Farmacologia.

Orientador: Thiago Mattar Cunha

Palavras chave: Receptores do tipo NOD, RIPK2, Dor neuropática, Células Gliais, hipersensibilidade nociceptiva. 


\section{FOLHA DE APROVAÇÃO}

Flávia Viana Santa-Cecília

\section{Papel dos receptores intracelulares NOD1 e NOD2 na gênese da dor neuropática}

Tese apresentada ao programa de Pósgraduação do Departamento de Farmacologia da Faculdade de Medicina de Ribeirão Preto da Universidade de São Paulo para a obtenção do título de Doutor em Ciências.

Área de Concentração: Farmacologia

Aprovado em: 29 de julho de 2015.

\section{Banca Examinadora:}

Prof. Dr. Thiago Mattar Cunha Instituição: FMRP-USP Assinatura:

Profa. Dra. Fabíola Dach Eckeli

Instituição: HCFMRP-USP Assinatura:

Prof. Dr. Dario Simões Zamboni

Instituição: FMRP-USP Assinatura:

Profa. Dra. Vanessa Olzon Zambelli Instituição: IBU-SP Assinatura:

Profa. Dra. Djane Braz Duarte Instituição: FCS-UnB Assinatura: 
Trabalho realizado no Laboratório de Dor e Inflamação do Departamento de Farmacologia da Faculdade de Medicina de Ribeirão Preto - Universidade de São Paulo com auxílio da Fundação de Amparo à Pesquisa do Estado de São Paulo (FAPESP) e da Coordenação de Aperfeiçoamento de Pessoal de Nível Superior (CAPES). 
Dedicatória 
À Deus e aos meus pais, Lenira e José Humberto, que são infinitamente meu porto seguro, minhas inspirações diárias em busca de meus objetivos. 
Agradecimentos 
Agradeço,

À Deus, dono de todo conhecimento e sabedoria, por me conceder mais essa conquista, por estender suas mãos nos momentos de desânimo e ter me dado condições para alcançar todos os meus objetivos. Confiar Nele me fez acreditar que tudo é possível.

Aos meus pais e irmãos por compartilhar momentos de dificuldades e alegrias e, principalmente, por todo o incentivo, amor e paciência dedicados durante toda minha vida. Obrigada por sempre acreditarem em minha capacidade.

Ao Prof. Dr. Thiago Mattar Cunha, pela orientação na realização deste trabalho, pelo constante incentivo, apoio, confiança e pelo exemplo de dedicação.

Aos Prof. Dr. Sérgio Henrique Ferreira e Dr. Fernando de Queiroz Cunha pela disponibilização de seu laboratório, pela rica convivência e contribuição para minha formação.

Aos professores componentes desta banca examinadora, pela disponibilidade e atenção.

À Prof. Dra. Rita Raisman pela oportunidade de ter realizado meu doutorado sanduíche no Institut du cerveau et de la moelle épinière da Universidade Pierre et Marie Curie em Paris, França, no ano de 2013, que, além de ter me proporcionado um grande experiência de vida, com certeza, contribuiu muito para minha formação como pesquisadora.

Aos meus queridos e especiais amigos do coração Miriam Fonseca e David Ferreira, pela grande parceria na realização deste trabalho, prestatividade, confidências, amizade mais que especial, momentos alegres, carinho, dedicação e atenção.

Aos pra sempre amigos Rafael Poloni, Cristina Setim, Vanessa Borges, Nathalia Borges, Thalita Freitas, Larisse Freitas e Larrisa Garcia por terem me dado o prazer 
da convivência diária e amizade, pelo carinho e por todos os momentos inesquecíveis que vivemos juntos.

Ao Caio Abner, em quem sempre encontrei incentivo, companheirismo e muito amor. Você a cada dia se torna mais especial para mim.

À Andressa Duarte, Rafaela Pravato, Silvana Marchetti e Débora Ramos, "minhas irmãs de Ribeirão”, pela companhia diária, indispensável ajuda, carinho imensurável e, principalmente, pela grande amizade.

À Sara Hott e Gabriel Tavares pela amizade construída na fé e união firmada em Deus.

Aos demais amigos e colegas do Laboratório de Inflamação e Dor (LID) que de uma forma ou de outra me ajudaram, com conselhos, ensinamentos técnicos, amizade e companheirismo durante todos esses anos de convivência. Em especial ao André Saraiva, Cássia Silva, Rangel Leal, Alexandre Lopes, Flávio Protássio, Rafael Ferreira, Fernanda Castanheira, Jhimmy Talbot, Alexandre Kanashiro, Andreza Urba, Maria Claúdia Silva, Paula Viacava, Kalil Alves, Ricardo Kuzuda, Marcela Davoli e Paulo Henrique Melo.

Ao Guilherme Rabelo, pela ajuda em todas as etapas do desenvolvimento deste trabalho. Pela paciência, amizade e atenção.

Aos meus estimáveis técnicos do laboratório, Sérgio Rosa, Kátia dos Santos, Diva Amábile, Giuliana Bertozi e Eleni Gomes pelo empenho, prestatividade, amizade, dedicação, ensinamentos, colaboração e apoio constante para realização deste trabalho.

À especialista de laboratório, Ieda Regina, pela amizade verdadeira, confiança, profissionalismo, disponibilidade, participação, ensinamento das técnicas comportamentais e excelente cuidado dado a mim e aos animais de experimentação utilizados neste trabalho. 
À equipe do DOL (Dor On Line), pelas reuniões semanais que enriqueceram meu conhecimento e pelas produtivas discussões sobre dor. Sinto-me gratificado por ter feito parte deste grupo.

Aos docentes e funcionários do Departamento de Farmacologia da FMRP-USP, pela convivência e oportunidade de bons aprendizados.

Aos funcionários da secretaria do Departamento de Farmacologia da FMRP-USP Sônia Maria, Fátima e José Waldik Ramon, pela eficiência, dedicação, amizade e competência.

Aos bioteristas, Júlio, Dener, Orlando, Inês, Eliana e Marquinhos, pelo cuidado com os animais de experimentação, tão importantes para este trabalho, conversas extrovertidas e alegria.

À FAPESP e ao CNPq, pelo auxílio financeiro indispensável para a realização deste trabalho.

Enfim, a todos que fizeram parte desta caminhada de crescimento profissional e pessoal, o meu muito obrigada ! 
“A tarefa não é tanto ver aquilo que ninguém viu, mas pensar o que ninguém ainda pensou sobre aquilo que todo mundo vê." Arthur Schopenhauer

“É preciso força pra sonhar e perceber que a estrada vai além do que se vê."

Los Hermanos 


\section{Resumo}




\section{SANTA-CECÍLIA, F. V. Papel dos receptores intracelulares NOD1 e NOD2 na}

gênese da dor neuropática. Tese de Doutorado - Departamento de Farmacologia da Faculdade de Medicina de Ribeirão Preto - Universidade de São Paulo, Ribeirão Preto, SP, 2015.

Nos últimos anos, inúmeros avanços têm sido alcançados no que diz respeito aos mecanismos moleculares que participam na indução e manutenção da dor crônica, incluindo ativação glial. Já foi demonstrado que alguns receptores de reconhecimento padrão (PRRs), como os receptores do tipo Toll (TLRs) participam desse processo e, que em modelos de inflamação/infecção do Sistema Nervoso Central, os TLRs e os receptores do tipo NOD (NLRs) cooperam na ativação das células da glia, o que nos levou a hipotetizar que os receptores NOD1 e NOD2 também possam desempenhar um papel importante no processo de dor crônica. O NOD2 é responsável pela detecção intracelular do muramil dipeptídeo (MDP) enquanto que NOD1 reconhece o ácido diaminopimélico (iE-DAP), ambos padrões moleculares associados a patógenos (PAMPs) encontrados no peptideoglicano de bactérias. Após o reconhecimento, NLRs recrutam diretamente RIPK2 (proteína 2 de interação com o receptor RICK), uma serina-treonina quinase importante na ativação do fator nuclear kB (NF-kB). Assim, o objetivo do presente estudo foi avaliar a participação de NOD1 e NOD2, via RIPK2, no desenvolvimento da hipersensibilidade mecânica neuropática focando principalmente nos mecanismos espinais envolvidos. Dessa maneira, foi observado que os animais $\mathrm{NOD}^{-/-}$, NOD2 $2^{-/-}$e RIPK2 $2^{-/}$apresentaram redução significativa da hipersensibilidade nociceptiva mecânica quando comparado aos animais selvagens após indução de neuropatia periférica pelo modelo experimental de lesão limitada do nervo isquiático (SNI, Spared Nerve Injury). Ao contrário, a hipersensibilidade inflamatória induzida pelo adjuvante completo de Freud (CFA) não foi reduzida nesses animais. A redução da dor neuropática em $\mathrm{NOD}^{-{ }^{-}}$, NOD2 $2^{-/-}$e RIPK2 $2^{-/-}$foi associada a uma diminuição da expressão de IBA-1, GFAP, IL-1 $\beta$, TNF- $\alpha$ e P2X4 na medula espinal quando comparado ao grupo WT. In vitro, foi observado que culturas primárias de micróglia não induziram liberação de IL-1 $\beta$, TNF- $\alpha$, IL-6 em resposta ao MDP $(10 \mu \mathrm{g} / \mathrm{mL})$ e iE-DAP (100ng/mL). No entanto, quando o MDP foi administrado juntamente com uma baixa concentração de lipopolissacarídeo (LPS) (0,1ng/mL), apresentou uma forte produção destas citocinas. Além disso, também foi demonstrado que células periféricas que infiltram na medula espinal podem expressar NOD1 e 
NOD2 e portanto serem capazes de induzir hipersensibilidade mecânica e ativação microglial após a indução de neuropatia. Dessa maneira, os resultados sugerem que NOD1 e NOD2, via RIPK2, contribuem para a gênese da dor neuropática, possivelmente mediando a liberação de citocinas pró-nociceptivas e a ativação de células gliais. Além disso, os resultados apontam ação potencial de NOD2 com TLR4 no intuito de estimular a ativação glial. Estes mecanismos representam uma nova abordagem para elucidar os mecanismos envolvidos na fisiopatologia da dor crônica e um possível alvo para o desenvolvimento de drogas para o tratamento da dor neuropática.

Palavras-chave: receptores do tipo NOD, RIPK2, dor neuropática, hipersensibilidade nociceptiva, células gliais, citocinas pró-inflamatórias. 
Abstract 


\section{SANTA-CECÍLIA, F. V. Role of NOD1 and NOD2 intracelular receptors in the}

genesis of neuropathic pain. Thesis $(\mathrm{PhD})$ - Department of Pharmacology of the Ribeirão Preto Medical School - University of São Paulo, Ribeirão Preto, SP, 2015.

In the last years, many advances have been made related to the molecular mechanisms involved in the induction and maintenance of chronic pain, including glial activation. It has been shown that some pattern recognition receptors (PRRs) such as Toll-like receptors (TLRs) are involved in this process, and that in inflammation/infection models of the CNS, the TLRs and Nod-like receptors (NLRs) cooperate in activation of glial cells, which led us to hypothesize that NOD1 and NOD2 receptors may also play an important role in chronic pain process. NOD2 are responsible by intracellular detection of muramyl dipeptide (MDP) and NOD1 detects meso-diaminopimelic acid (iE-DAP), pathogen-associated molecular patterns (PAMPs) found in the peptidoglycan from bacteria. Upon recognition, NLRs recruit directly RIPK2, an adaptor protein, important in NLRs-mediated NFאB activation. In the present study, we aimed to evaluate the participation of NOD1 and NOD2, via RIPK2, in the development of neuropathic mechanical hypersensitivity focusing mainly on spinal mechanisms involved. The results demonstrate that $\mathrm{NOD}^{-{ }^{--}}$, NOD2 $2^{-{ }^{-}}$, RIPK2 ${ }^{-{ }^{-}}$ showed a significant reduction in mechanical hypersensitivity when compared to WT mice, after submitted to an experimental model of neuropathic pain Spared Nerve Injury (SNI). Interestingly, CFA-induced chronic inflammatory hypersensitivity was not decreased in these mice. The reduction in neuropathic pain in $\mathrm{NOD}^{-/-}$, NOD2 $2^{-/-}$ and RIPK $2^{-/-}$mice was associated with a decrease in the expression of IBA-1, GFAP, IL-1 $\beta$, TNF- $\alpha$ and P2X4 in spinal cord when compared with WT. In vitro, it was observed that primary cultures of microglia did not produce IL- $1 \beta$, TNF- $\alpha$, IL-6 in response to MDP $(3 \mu \mathrm{g} / \mathrm{mL})$ or iE-DAP (100ng/mL). However, MDP, together with an ineffective concentration of LPS $(0.1 \mathrm{ng} / \mathrm{mL})$, produced a robust production of these cytokines. Moreover, it was also demonstrated that peripheral cells infiltrating the spinal cord could express NOD1 and NOD2 and thus, be able to induce mechanical hypersensitivity and microglial activation after induction of peripheral neuropathy. The results suggest that NOD1 and NOD2, via RIPK2, contribute to the genesis of neuropathic pain, possibly by mediating the release of pronociceptive cytokines and increased glial cells activation. Moreover, the results indicate potential action of NOD2 with TLR4 in attempt to stimulate glial cells activation. These mechanisms 
represent a novel approach for elucidating the pathophysiology of chronic pain, and a target for the development of drugs for the treatment of neuropathic pain.

Keywords: NOD-like receptors, RIPK2, neuropathic pain, nociceptive hypersensitivity, glial cells, proinflammatory cytokines. 


\section{Lista de ilustrações}




\section{LISTA DE ILUSTRAÇÕES}

Ilustração 1 - Via de sinalização de NOD1 e NOD2 ..................................... 48

Ilustração 2 - Esquema do modelo experimental de dor neuropática SNI...... 57

Ilustração 3 - Modelo esquemático do possível mecanismo pelo qual NOD1 e NOD2 contribuem para a gênese da dor neuropática ............. 141 


\section{Lista de figuras}




\section{LISTA DE FIGURAS}

Figura 1 - Expressão de NOD1 e NOD2 na medula espinal.......................... 72

Figura 2 - Expressão de NOD1 medula espinal........................................... 73

Figura 3 - Expressão de NOD1 nos neurônios da medula espinal após lesão

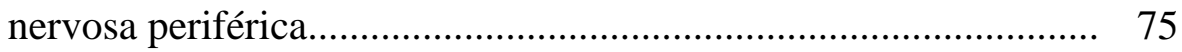

Figura 4 - Expressão de NOD1 nos neurônios da medula espinal após lesão nervosa periférica..................................................................... 76

Figura 5- Avaliação da nocicepção mecânica em animais $\mathrm{NOD}^{-/}$e

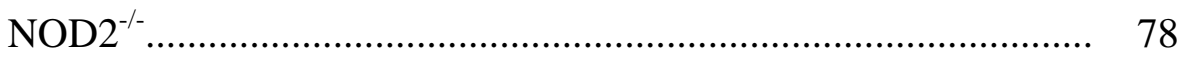

Figura 6 - Avaliação da nocicepção térmica em animais NOD1 ${ }^{-/-}$e NOD2 $2^{-/-} .78$

Figura 7 - Avaliação da nocicepção química em animais $\mathrm{NOD}^{-/-}$e NOD2 ${ }^{-/-} \quad 79$

Figura 8 - Avaliação da nocicepção mecânica em camundongos machos submetidos à neuropatia periférica........................................... 82

Figura 9 - Avaliação da nocicepção mecânica em camundongos fêmeas submetidos à neuropatia periférica.

Figura 10 - Avaliação da nocicepção mecânica em camundongos submetidos à inflamação periférica

Figura 11 - Perfil de ativação de micróglia em camundongos após indução de neuropatia periférica.

Figura 12 - Avaliação da ativação de micróglia em camundongos NOD1 $^{-/}$e $\mathrm{NOD} 2^{-/-}$

Figura 13 - NOD1 e NOD2 são requeridos para ativação microglial na medula espinal após lesão nervosa periférica.

Figura 14 - NOD1 e NOD2 são requeridos para ativação microglial na medula espinal após lesão nervosa periférica.

Figura 15 - Avaliação da ativação de astrócitos em camundongos NOD1 ${ }^{-1-} \mathrm{e}$ $\mathrm{NOD} 2^{-1-}$

Figura 16 - NOD2 é requerido para ativação astrocitária na medula espinal após lesão nervosa periférica.

Figura 17 - NOD2 é requerido para ativação astrocitária na medula espinal após lesão nervosa periférica.

Figura 18 - Avaliação da liberação de citocinas pró-inflamatórias em animais 
$\mathrm{NOD}^{-/-}$e NOD $2^{-/-}$

Figura 19 - Perfil de expressão de citocinas pró-inflamatórias em culturas de células microgliais estimuladas por LPS.

Figura 20 - Perfil de expressão de citocinas pró-inflamatórias em culturas de células microgliais estimuladas por iE-DAP.

Figura 21 - Perfil de expressão de citocinas pró-inflamatórias em culturas de células microgliais estimuladas por MDP.

Figura 22 - Perfil de expressão de citocinas pró-inflamatórias em culturas de células microgliais estimuladas iE-DAP+LPS.

Figura 23 - Perfil de expressão de citocinas pró-inflamatórias em culturas de células microgliais estimuladas MDP+LPS.

Figura 24 - Perfil de expressão de citocinas pró-inflamatórias em culturas de células microgliais estimuladas MDP+LPS.

Figura 25 - Avaliação da nocicepção mecânica em animais RIPK2 $2^{-/}$.

Figura 26 - Avaliação da nocicepção térmica em animais RIPK2 $2^{-1-}$.....

Figura 27 - Avaliação da nocicepção química em animais RIPK2 ${ }^{-/}$.

Figura 28 - Avaliação da nocicepção mecânica em animais RIPK2 ${ }^{-/}$ submetidos à neuropatia periférica.

Figura 29 - Avaliação da nocicepção mecânica em camundongos RIPK2 $2^{-/-}$ submetidos à inflamação periférica.

Figura 30 - Avaliação da ativação de micróglia em camundongos RIPK $2^{-/} \ldots$.

Figura 31 - RIPK2 é requerido para ativação microglial na medula espinal após lesão nervosa periférica.

Figura 32 - RIPK2 é requerido para ativação microglial na medula espinal após lesão nervosa periférica.....

Figura 33 - Avaliação da ativação de astrócitos em camundongos RIPK2 $2^{-{ }^{-}} \ldots$...

Figura 34 - Avaliação da liberação de citocinas pró-inflamatórias em animais RIPK $2^{-/-}$

Figura 35 - Perfil de expressão de P2X4 em camundongos após indução de neuropatia periférica.

Figura 36 - Avaliação da expressão de P2X4 em camundongos $\mathrm{NOD}^{-1-}$, NOD2 $2^{-/-}$e RIPK2 $2^{-1-}$

Figura 37 - Padronização da construção de animais quimeras, selvagens e 
deficientes para NOD1 e NOD2.

Figura 38 - Infiltrado de células derivadas da medula óssea $\left(\mathrm{GFP}^{+}\right)$na medula espinal em animais quimeras de medula óssea, após indução de neuropatia periférica.

Figura 39 - Infiltrado de células derivadas da medula óssea $\left(\mathrm{GFP}^{+}\right)$na medula espinal em animais quimeras de medula óssea, após indução de neuropatia periférica

Figura 40 - Ativação microglial (IBA-1) na medula espinal de animais quimeras de medula óssea, após indução de neuropatia periférica.

Figura 41 - Ativação microglial (IBA-1) na medula espinal de animais quimeras de medula óssea, após indução de neuropatia periférica.

Figura 42 - Papel do infiltrado de células periféricas derivada da medula óssea na hipersensibilidade nociceptiva mecânica mediada por NOD1 e NOD2, após indução de neuropatia periférica. 


\section{Lista de abreviaturas}




\section{LISTA DE ABREVIATURAS}

$\alpha:$ alfa

及: beta

${ }^{\mathbf{0}} \mathbf{C}$ : graus Celsius

${ }^{-/}$: deficientes

AUC: área sob a curva

BDNF: fator neurotrófico derivado do cérebro

BSA: albumina bovina sérica

CARD: domínio de recrutamento de caspase

CCI: constrição crônica do nervo ciático

CCL21: quimiocina de tecido linfoide secundário

CDc: lado contralateral do corno dorsal da medula espinal

CDi: lado ipsilateral do corno dorsal da medula espinal

CFA: adjuvante completo de Freund

CR3 ou CD11b: receptores de complemento do tipo 3

CVc: lado contralateral do corno ventral da medula espinal

CVi: lado ipsilateral do corno ventral da medula espinal

DAMPs: padrões moleculares associados à lesão (DAMPs)

DNA: ácido desoxirribonucleico

DNAc: ácido desoxirribonucleico complementar

E.P.M.: erro padrão da média

ELISA: ensaio imunoenzimático

FTC: fluorescência total corrigida

g: gramas 
GFAP: proteína glial fibrilar ácida

GFP: proteína fluorescente verde

GRD: gânglio da raiz dorsal

h/ hs: hora/ horas

HMGs: proteínas de alta mobilidade

HSPs: proteínas de choque térmico

IBA-1: proteína adaptadora ligante de cálcio ionizado

iE-DAP: $\gamma$-D-meso-glutamil-ácido diaminopimélico

IL: interleucina

KC: quimiocina derivada de queratinócito

kDa: quilo Dalton

L4, L5 ou L6: $4^{\text {a }}, 5^{\text {a }}$ ou $6^{\text {a }}$ vértebra lombar

LRR: repetições ricas em leucina

MAPKs: proteínas quinases ativadas por mitógenos

MCP-1 ou CCL2 : proteína quimiotática de monócitos 1

MDP: muramil dipeptídeo

mg: miligrama

min: minutos

mL: mililitro

MMP: metaloproteinases de matriz

NF-кB: fator nuclear- $\kappa \mathrm{B}$

ng: nanogramas

NLRs: receptores do tipo NOD

nm: nanômetro

NOD: domínio de oligomerização de nucleotídeos 
p: pico

P2X4: receptor purinérgico de ATP

PAMPs: padrões moleculares associados a patógenos

PBS-T: tampão fosfato-salino contendo tween 20

PBS: tampão fosfato-salino

PFA: paraformaldeído

PGN: peptideoglicano

PNI: ligação parcial do nervo ciático

PRRs: receptores de reconhecimento padrão

RIPK2: proteína 2 de interação com o receptor RICK, CARDIAK e CCK

RNA: ácido ribonucleico

RNAm: RNA mensageiro

rpm: rotações por minuto

RT-qPCR: Reação em Cadeia da Polimerase após Transcrição Reversa em Tempo

Real

S ou seg: segundos

SDS-PAGE: eletroforese em gel de policrilamida de dodecil sulfato de sódio

SDS: dodecil sulfato de sódio

SNC: sistema nervoso central

SNI: lesão limitada do nervo (Spared Nerve Injury)

SNP: sistema nervoso periférico

SNSD: sobrenadante de neurônios sensoriais danificados

TLRs: receptores do tipo Toll

TNF- $\alpha$ : fator de necrose tumoral alfa

WT: tipo selvagem 
$\mu g:$ micrograma

$\boldsymbol{\mu L}:$ microlitros 
Sumário 


\section{SUMÁRIO}

1. Introdução ......................................................................................................................34

1.1. Dor crônica neuropática.......................................................................................34

1.2. Envolvimento de células gliais da medula espinal na dor neuropática.......37

1.3. Mecanismos de ativação glial durante o processo neuropático ....................40

1.4. Papel de receptores de reconhecimento padrão na dor neuropática ..........42

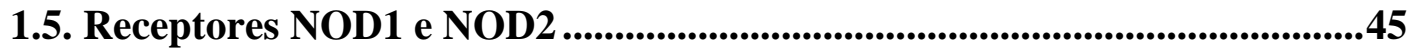

2. Objetivos ........................................................................................................................52

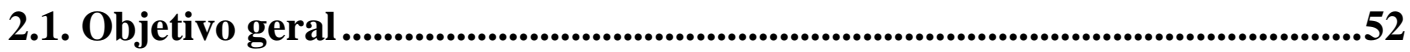

2.2. Objetivos específicos ......................................................................................52

2.2.1. Determinar a expressão e localização dos receptores NOD1 e NOD2 na medula espinal;

2.2.2. Verificar a nocicepção térmica e química em animais selvagens e deficientes para os receptores NOD1 e NOD2;

2.2.3. Avaliar a hipersensibilidade nociceptiva mecânica após a indução de lesão de nervos periféricos e inflamação periférica em animais selvagens e deficientes para os receptores NOD1e NOD2;

2.2.4. Determinar o perfil de indução de citocinas pró-inflamatórias e ativação de células gliais na medula espinal, em animais selvagens e deficientes para NOD1 e NOD2, após indução de neuropatia periférica;

2.2.5. Avaliar o perfil de liberação de citocinas pró-inflamatórias em culturas primárias de micróglia estimuladas por agonistas de NOD1 (iE-DAP), NOD2 (MDP) e TLR4 (LPS);

2.2.6. Determinar a contribuição da via de sinalização dependente de RIPK2 na hipersensibilidade mecânica, indução de citocinas pró-inflamatórias e ativação das células gliais na medula espinal, em animais selvagens e deficientes para RIPK2, após indução de neuropatia periférica;

2.2.7. Determinar o perfil de expressão de P2X4 na medula espinal, em animais selvagens e deficientes para NOD1, NOD2 e RIPK2, após indução de neuropatia periférica;

2.2.8. Determinar a contribuição do infiltrado de células periféricas derivadas da medula óssea na ativação microglial mediada por NOD1 e NOD2, após indução de neuropatia periférica; 
2.2.9. Avaliar o papel do infiltrado de células periféricas derivada da medula óssea na hipersensibilidade nociceptiva mediada por NOD1 e NOD2, após indução de neuropatia periférica.

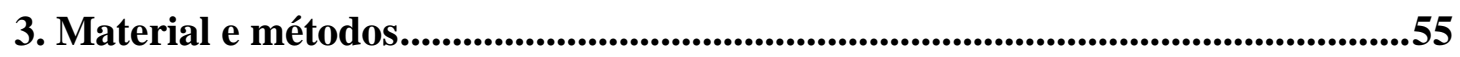

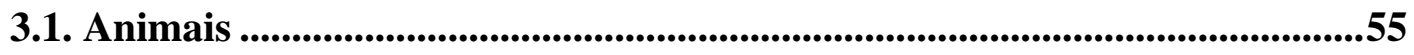

3.2. Drogas ............................................................................................................................55

3.3. Modelo experimental de dor neuropática...............................................56

3.4. Modelo experimental de dor inflamatória......................................................57

3.5. Avaliação nociceptiva ...........................................................................57

3.5.1. Teste de nocicepção mecânica: filamentos de von Frey .......................58

3.5.2. Teste de nocicepção química: formalina............................................58

3.5.3. Teste de nocicepção térmica: placa quente............................................59

3.6. Western Blotting .........................................................................................................59

3.6.1. Preparação das amostras de medula espinal: extração das proteínas 59

3.6.2. Eletroforese e ImunoBlotting 60

3.7. Avaliação da expressão gênica 62

3.7.1. Processamento das amostras e extração de RNA mensageiro (RNAm)

3.7.2 Síntese de DNA complementar (cDNA) e Reação em Cadeia da

Polimerase-Transcriptase Reversa em Tempo Real (RT-qPCR). 63

3.8. Imunofluorescência- Free Floating .................................................................64

3.9. Cultura primária de micróglia ...............................................................66

3.10. Estimulação microglial ...............................................................................66

3.11. Quantificação de citocinas pelo método de ELISA .................................67

3.12. Geração de animais quimeras de medula óssea ..............................................68

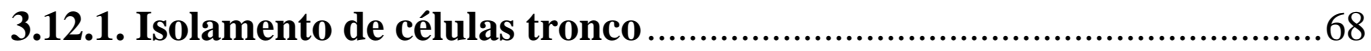

3.12.2. Construção dos camundongos quimeras ..........................................69

3.14. Análise estatística ......................................................................................................70

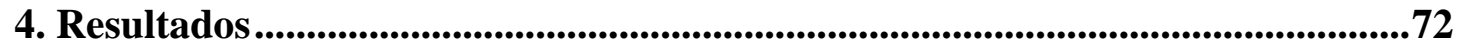

4.1. Expressão de NOD1 e NOD2 na medula espinal ........................................72

4.2. NOD1 é expresso nos neurônios da medula espinal após indução de neuropatia periférica 
4.3. Animais deficientes para NOD1 e NOD2 respondem normalmente a diferentes estímulos nocivos ..........................................................................................77

4.4. NOD1 e NOD2 contribuem para gênese da dor neuropática ......................80

4.5. NOD1 e NOD2 não estão envolvidos na indução da dor inflamatória........83

4.6. NOD1 e NOD2 contribuem para a ativação microglial após indução de neuropatia periférica

4.7. NOD1 e NOD2 contribuem para a ativação astrocitária após indução de neuropatia periférica

4.8. NOD1 e NOD2 induzem a liberação de citocinas pró-inflamatórias após indução de neuropatia periférica

4.9. O efeito potencial da ativação de TLR4 e NOD2 reforça a liberação microglial de citocinas pró-inflamatórias

4.10. A via de sinalização dependente de RIPK2 induz hipersensibilidade nociceptiva, ativação glial e liberação de citocinas pró-inflamatórias após indução de neuropatia periférica.

4.11. NOD1 e NOD2, via RIPK2, contribuem para a expressão de P2X4 após indução de neuropatia periférica.

4.13. Papel do infiltrado de células periféricas derivada da medula óssea na hipersensibilidade nociceptiva mediada por NOD1 e NOD2 após indução de

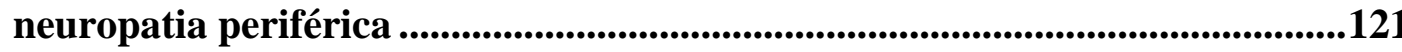

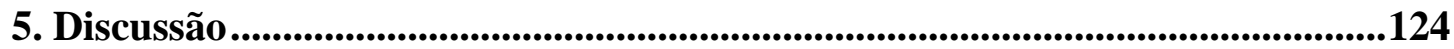

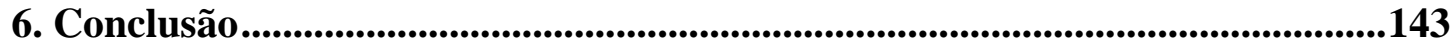

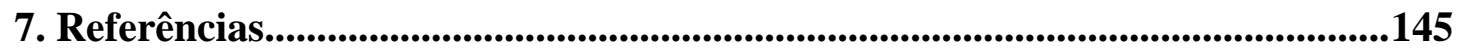

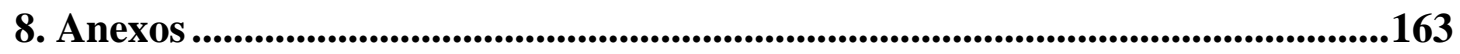

8.1. Comitê de ética ......................................................................................................163

8.2. Manuscrito para publicação (em elaboração) .........................................164 


\section{Introdução}




\section{Introdução}

\subsection{Dor crônica neuropática}

A dor é definida pela Associação Internacional para o Estudo da Dor (IASP) como sendo "uma experiência emocional e sensorial desagradável associada com uma lesão tecidual real ou potencial". De maneira simplificada a dor seria a "percepção desagradável de uma sensação nociceptiva" (noci: nocivo; cepção: recepção). Como uma experiência, a dor inclui não só a percepção consciente de um evento sensorial, mas também a análise cognitiva e resposta emocional associada com essa experiência (Julius \& Basbaum, 2001;Wieseler-Frank et al., 2004; Sandkuhler, 2009).

Apesar dos animais não apresentarem a capacidade de comunicar verbalmente a ocorrência de dor, quando são submetidos a um estímulo reconhecidamente nociceptivo, eles exibem respostas comportamentais, motoras e fisiológicas semelhantes às observadas em seres humanos. A partir da avaliação desses parâmetros podemos inferir que um animal está experimentando uma resposta álgica. Portanto, o termo nocicepção engloba respostas comportamentais e neurofisiológicas da dor, dissociando do caráter cognitivo-afetivo da resposta (Wieseler-Frank et al., 2004). Especificamente, a nocicepção refere-se à detecção de um estímulo nociceptivo (químico, térmico ou mecânico) por uma subpopulação de fibras nervosas periféricas, os receptores da dor (nociceptores), que codificam sinais para fornecer informações ao sistema nervoso central (SNC) da existência de um estímulo potencialmente lesivo (Julius \& Basbaum, 2001; Basbaum et al., 2009).

A dor crônica representa um crescente problema de saúde pública de nossa sociedade, uma vez que é frequentemente debilitante, intensa, constante e muitas 
vezes resistente a todas as terapias disponíveis atualmente no mercado (Cohen \& Mao, 2014). Estima-se que ela afete $30 \%$ dos adultos em todo o mundo, de forma que, cada vez mais, existe a necessidade de entendê-la visando o desenvolvimento de novos tratamentos (Johannes et al., 2010, Ji et al., 2014). A dor crônica compreende vários tipos diferentes de dor, incluindo dor inflamatória, dor do câncer e dor neuropática (Dworkin et al., 2010; Kalso et al., 2004).

As dores crônicas de origem inflamatória são determinadas por injúria tecidual periférica e ativação persistente de nociceptores, resultando em plasticidade funcional do sistema nervoso (alterações na sensibilidade nociceptiva e expressão de receptores, canais iônicos, neurotransmissores e enzimas) contribuindo para a persistência do quadro doloroso, independentemente da resolução do processo inflamatório (Kandel et al., 2000; Coutaux et al., 2005). Outro tipo de dor crônica que apresenta uma grande importância clínica é a neuropática.

A dor neuropática é resultante de doenças ou injúrias que acometem diretamente o sistema nervoso somatossensitivo periférico (SNP) ou o SNC, como, por exemplo, após lesões traumáticas, intervenção cirúrgica, doenças como diabetes ou infecções, entre outras (Scholz and Woolf, 2002; Zimmermann, 2001; Gwak and Hulsebosch, 2009; Cohen \& Mao, 2014).

A caracterização da dor neuropática é complexa e heterogênea, pois os sintomas podem oscilar no tipo, na intensidade, no tempo etc. Mas, as principais características da dor neuropática são hiperalgesia (resposta aumentada a um estímulo previamente doloroso), dor espontânea e alodinia (dor resultante de estímulos normalmente não dolorosos) (Woolf \& Mannion, 1999; Austin \& Moalem-Taylor, 2010; Trang et al., 2012). Assim sendo, o dano ao tecido nervoso resulta em amplificação da resposta frente a estímulos tanto nocivos como inócuos, que passam a ser percebidos como 
dolorosos (Walker et al., 1995, Baron \& Binder, 2004). Essa amplificação, tanto periférica como central, ocorre devido à alteração da expressão de receptores, canais iônicos e neurotransmissores, aumento da excitabilidade neuronal e geração ectópica de potenciais de ação, morte das células neuronais, facilitação e desinibição da transmissão sináptica, além de mudanças na conectividade sináptica e reorganização dos circuitos nociceptivos centrais (Austin \& Moalem-Taylor, 2010).

O tratamento farmacológico da dor neuropática é bem limitado, sendo que, atualmente, as opções mais eficazes são as mesmas que anos atrás: analgésicos opióides, anticonvulsivantes, antidepressivos, antagonistas dos receptores N-metil-Daspartato (NMDA) e corticoides (Mika et al., 2013). Entretanto, essas opções terapêuticas não são eficazes para a maioria dos usuários e, naqueles que são responsivos a uma dessas opções, em algum momento, geralmente, a terapia medicamentosa se torna falha ou perde sua eficácia, além de causar diversos efeitos colaterais e adversos.

Portanto, estudos são necessários para uma melhor compreensão da fisiopatologia da dor neuropática no intuito de desenvolvimento novos fármacos. Dessa maneira, na última década houve uma explosão de estudos que apontam que a patogênese da dor neuropática não é unicamente caracterizada por alterações na atividade do sistema neuronal, como se acreditava anteriormente. Ao contrário, envolve também uma interação neuroimune entre neurônios e células da glia, visto que as células gliais da medula espinal desempenham papel importante na manutenção da sensibilização central e consequentemente, na perpetuação da dor (Tsuda et al., 2005; DeLeo \& Yezierski, 2001; Lee et al., 2004; Watkins et al., 2003; Woolf \& Mannion, 1999 Scholz \& Woolf, 2007). 


\subsection{Envolvimento de células gliais da medula espinal na dor neuropática}

As células da glia, que superam os neurônios em número, constituem cerca de $70 \%$ da população de células do SNC e são classificadas em astrócitos, oligodendrócitos e micróglia. Apesar de não serem células transmissoras de impulsos nervosos como os neurônios, participam na síntese, liberação e recaptação de diferentes neurotransmissores do sistema nervoso (Mika et al., 2013; Gosselin et al., 2010). Elas também preservam a integridade da barreira hematoencefálica e da bainha de mielina, nutrem os neurônios e participam de mecanismos de defesa (Watkins et al., 2005; Watkins et al., 2007). A importância das células gliais no SNC e o papel da comunicação entre elas e os neurônios têm sido descritos em diversos estudos.

A micróglia é um tipo celular não neuronal presente na medula espinal e cérebro e que responde a condições adversas fisiológicas como trauma, isquemia, inflamação e infecção (Tsuda et al., 2005; Beggs \& Salter, 2007; Milligan \& Watkins, 2009; Trang et al., 2006). Constituem apenas 5-10\% de glia do SNC total. Basicamente, é classificada em dois subtipos: micróglia residente, derivada de precursores que migram do saco vitelínico para o SNC, onde residem por toda a vida e micróglia derivada da medula óssea, que são macrófagos perivasculares hematopoiéticos que infiltram no SNC durante processos patológicos como lesão cerebral, esclerose lateral amiotrófica, esclerose múltipla, encefalomielite autoimune experimental ou doença de Alzheimer (Zhang et al., 2007; Prinz \& Priller, 2014; Sawada et al., 2014).

Uma vez ativada, a micróglia rapidamente se converte para um estado reativo através de uma série de progressivas mudanças celulares e moleculares, incluindo alterações morfológicas de uma micróglia de pequeno corpo celular, com finas e 
longas ramificações para uma micróglia hipertrófica, com formato ameboide (Eriksson et al., 1993). Além disso, é observada a expressão de diversos marcadores: receptores de complemento do tipo 3 (CR3) ou CD11b; proteína adaptadora ligante de cálcio ionizado (Iba-1); cluster de diferenciação CD14; receptores Toll-like 4 (TLR4), bem como a ativação da p38-proteína ativada por mitógeno (MAPK) (McMahon et al., 2005; Terayama et al., 2008).

Essa ativação microglial, observada após a indução de inflamação ou neuropatia periférica, já foi amplamente descrita em diversos modelos, como por exemplo inflamação induzida CFA (Raghavendra et al., 2004), constrição crônica do nervo ciático (CCI) (Colburn et al., 1997), ligação parcial do nervo ciático (PNI) (Coyle, 1998), Spared Nerve Injury (SNI) (Beggs \& Salter, 2007) e ligação do nervo espinal (Coyle, 1998). No contexto de dor neuropática, a micróglia é um dos primeiros tipos celulares a ser ativado, dentro de 4 horas após lesão periférica (Tanga et al., 2004), permanecendo ativa por diversos meses (Clark et al., 2007; Coyle, 1998).

Os astrócitos representam a maior população de células do SNC e através da expressão de numerosas proteínas transportadoras, são capazes de manter a homeostase pela regulação de íons extracelulares, prótons e neurotransmissores (Hatton, 1999; Haydon, 2001; Hansson \& Ronnback, 2003; Sofroniew \& Vinters, 2010). Eles tornam-se ativados em resposta aos mesmos estímulos que induzem ativação de micróglia ou pelos produtos liberados por ela quando ativada (Dong \& Benveniste, 2001). A ativação de astrócitos é morfologicamente caracterizada por hipertrofia e um aumento na produção da proteína glial fibrilar ácida (GFAP), componente dos filamentos de tamanho intermediário do citoesqueleto celular, presente nestas células (Watkins \& Maier, 2003). 
Experimentalmente, esse comportamento de ativação, observada pela marcação com GFAP, é claramente visível no corno dorsal da medula espinal após uma variedade de diferentes tipos de lesões, incluindo constrição crônica do nervo ciático, ligação do nervo espinal, hemissecção da medula espinhal, modelo experimental de câncer ósseo, radiculopatia lombar, inflamação induzida por adjuvante completo de Freund (CFA), nocicepção induzida por formalina e nocicepção induzida por veneno de cobra (Ren, 2010).

Após indução de neuropatia periférica, foi demonstrado que ativação de astrócitos ocorre tardiamente ao ser comparado com a ativação de micróglia, ou seja, a partir do quarto dia, sugerindo importante papel na manutenção da dor neuropática (Colburn et al., 1999; Romero-Sandoval et al., 2008; Tanga et al., 2004). Animais deficientes para GFAP respondem a lesão nervosa periférica com um desenvolvimento normal de hipersensibilidade a dor, entretanto com menor duração (Kim et al., 2009). Da mesma maneira, o tratamento com GFAP antisense em ratos neuropáticos é capaz de reverter a dor já estabilizada por seis semanas após a lesão (Kim et al., 2009). Além disso, esse tipo celular permanece ativado na medula espinal até três meses após indução de neuropatia (Coyle, 1998; Ledeboer et al., 2005).

Um estudo comparativo entre a expressão espinal de Iba-1 e GFAP em modelos animais de dor neuropática mostrou que após a transecção do nervo espinal L5, ocorre primeiramente um aumento na expressão de Iba-1 em todo corno dorsal no primeiro dia após realização da cirurgia, sendo que esse comportamento persiste por 7 dias. Com relação ao GFAP, não houve expressão significativa no primeiro dia após indução, sendo observado um aumento no quarto e sétimo dia após realização da neuropatia (Romero-Sandoval et al., 2008). Em contraste, um trabalho descreveu um importante papel da micróglia na manutenção a longo prazo de hiperalgesia, 
mostrando que esse comportamento pode ser atenuado com a administração de um inibidor glial 4-6 semanas pós-lesão (Tawfik et al., 2007), confirmando o envolvimento da micróglia tanto no desenvolvimento como na manutenção da hipersensibilidade a dor (Clark et al., 2007; Ledeboer et al, 2005;. Marchand et al., 2009).

Portanto, a resposta do SNC à lesão nervosa periférica se caracteriza pela participação das células gliais e consequente facilitação da condução nervosa da dor. Estudos que envolvem o bloqueio farmacológico glial demonstram que a utilização de inibidores, como por exemplo, flurocitrato, minociclina e propentofilina são capazes de atenuar os sinais da dor neuropática (Watkins et al., 2001; Raghavendra et al., 2003).

\subsection{Mecanismos de ativação glial durante o processo neuropático}

Vários mecanismos têm sido propostos para explicar quais os eventos moleculares que desencadeiam a ativação das células gliais na medula espinal após uma lesão periférica de nervos e como os sinais resultantes dessa ativação contribuem para a gênese da dor crônica. $\mathrm{O}$ que se acredita fundamentalmente é que durante processos de lesão nervosa periférica (neuropatia), a constante estimulação das vias nociceptivas leva a uma liberação intensa de neurotransmissores excitatórios (glutamato, substância P, ATP) na medula espinal, os quais seriam responsáveis pela ativação das células da glia (Milligan \& Watkins, 2009). Além disso, outras moléculas candidatas, como quimiocinas, em especial a fractalkina (CX3CL1/CXCR1), proteína quimiotática de monócitos 1 (MCP-1) ou (CCL2/CCR2), quimiocina de tecido linfoide secundário (CCL21/CXCR3) e 
metaloproteinases de matriz como a MMP9 e MMP2, estão sendo apontadas como mediadores da interação neurônios-glia (Clark et al., 2009; Milligan et al., 2004; Kawasaki et al., 2008; Old \& Malcangio, 2012 ).

Como resultado da sua ativação, as células da glia promovem a liberação de proteínas imunes clássicas em resposta a sinais neuronais incluindo citocinas próinflamatórias como a IL-1 $\beta$, IL-6 e TNF- $\alpha$ (DeLeo \&Yezierski, 2001; Watkins \& Maier, 2003; Watkins et al., 2003). Embora os mecanismos pelos quais essas citocinas aumentem a excitabilidade neuronal e contribuem para o processo neuropático estarem em constante investigação, sugere-se que elas medeiam à comunicação neurônio-glia e que podem, independentemente ou em combinação, induzir a sensibilização central e consequentemente, a perpetuação do processo doloroso (Wieseler-Frank et al., 2005; Ozaktay et al., 2006; Kawasaki et al., 2008).

Uma molécula chave que modula a atividade microglial é o ATP, um ligante endógeno da família de receptores purinérgicos $\mathrm{P} 2$, que consiste em receptores ionotrópicos P2X e metabotrópicos P2Y (Burnstock, 2006, 2007; Inoue, 2002; Inoue \& Tsuda, 2006). Após a lesão de um nervo periférico, a micróglia ativada induz um aumento na expressão do receptor P2X4, o qual também participa na gênese da dor crônica (Tsuda et al., 2003). O receptor P2X4 consiste em um canal iônico presente na superfície celular, que medeia efeitos fisiológicos produzidos pelo ATP, por meio de um aumento intracelular de cálcio e ativação das MAPKs (Guo et al., 2006). Tsuda et al. (2003) demonstraram que a alodinia tátil induzida por lesão periférica de nervos é mediada por receptores P2X4 na medula espinal. Além disso, descobertas posteriores sugeriram que a ativação desses receptores, expressos na micróglia, induzem a liberação do fator neurotrófico derivado do cérebro (BDNF), responsável por causar uma desinibição dos neurônios do corno dorsal da medula e 
consequentemente hiperexcitabilidade neuronal, fundamental para o desenvolvimento da dor neuropática (Coull et al., 2005). Portanto, os mediadores liberados por células gliais contribuem para o desenvolvimento de um ambiente pró-inflamatório na região da sinapse ocorrida no corno dorsal da medula, que persiste a distância da lesão nervosa inicial e que progride para regiões superiores gerando hipersensibilização e persistência da dor (Mika et al., 2013).

Além dos mecanismos citados acima, recentes trabalhos têm indicado que os receptores de reconhecimento padrão (PRRs) também desempenham papel crucial na ativação das células gliais da medula espinal, contribuindo para indução e manutenção da dor neuropática (Tanga et al., 2005; Nicotra et al., 2012).

\subsection{Papel de receptores de reconhecimento padrão na dor neuropática}

O sistema imune é capaz de reconhecer uma ampla variedade de microrganismos e suas moléculas através de diferentes receptores expressos por células imunes, sendo esse reconhecimento fundamental para geração de uma resposta imune adquirida apropriada (Moreira \& Zamboni, 2012). Assim, esse processo ocorre por meio da interação de estruturas microbianas conservadas, comumente referidos como padrões moleculares associados a patógenos (PAMPs), com PRRs específicos. Dentre esses PRRs, os receptores do tipo Toll (TLRs: Toll-like receptors), receptores do tipo NOD: domínio de oligomerização de nucleotídeos (NLRs: NOD-like receptors), receptores do tipo RIG-1: ácido retinóico indutível do gene 1 (RLRs: RIG1-like receptors) e receptores do tipo AIM2: ausente na melanoma 2 (ALRs: AIM2like receptors) têm sido amplamente estudados e desempenham um importante papel sendo a primeira linha de defesa contra agentes infecciosos (Chenet al., 2009; 
Takeuchi \& Akira, 2010; Kumar et al., 2011).

Além disso, durante processos de lesão tecidual, um grupo específico de substâncias endógenas é liberado tanto no local da lesão, participando na indução da resposta inflamatória local, bem como podendo atingir a circulação, mediando processos fisiopatológicos que acontecem em órgãos distantes ao órgão lesionado. Este grupo de substâncias, também reconhecido pelos PRRs, é denominado padrões moleculares associados à lesão (DAMPs) e são liberados por células necróticas, estressadas ou ativadas e por moléculas da matriz extracelular após um dano tecidual ou injúria (Bianchi, 2007; Piccinini \& Midwood, 2010; Land, 2015).

Os PRRs compreendem um conjunto de sensores presentes na superfície da célula, no compartimento citosólico ou endossomal. Sua ativação por estímulos microbianos ou endógenos resulta na ativação de várias vias de sinalização intracelulares, incluindo o fator nuclear- $\mathrm{B}(\mathrm{NF}-\kappa \mathrm{B})$, as MAPKs e o interferon tipo I (IFN), levando a indução de respostas pró-inflamatórias e antimicrobianas (Akira et al., 2006). A maioria do conhecimento sobre PRRs deriva de estudos sobre os TLRs, que se localizam tanto na superfície celular quanto em endossomas (Takeda \& Akira, 2005; Uematsu \& Akira, 2007), e os receptores NLRs, que são sensores citosólicos intracelulares (Chisholm et al., 2006).

A proteína Toll foi originalmente descoberta na década de 1990, a partir da mosca da fruta Drosophila melanogaster, sendo essencial para a proteção do inseto contra infeções fúngicas (Hashimoto et al., 1988; Belvin \& Anderson, 1996; Lemaitre et al., 1996). Em 1997 foi identificado e caracterizado um homólogo da proteína Toll em humanos sendo denominado TLR (Medzhitov et al., 1997). Atualmente, existem 13 TLRs descritos, sendo 10 TLRs em humanos (TLR1-10) e 12 TLRs em camundongos (TLR1-9; 11-13) (Kawai \& Akira, 2010; Takeuchi \& Akira, 2010). 
Esses receptores são caracterizados por repetições ricas em leucina (LRRs), uma região transmembrana seguida por um domínio citoplasmático homólogo Toll/IL-1R (TIR). Já os NLRs foram identificados primeiramente em plantas, onde desempenham função crítica de resistência a doenças promovidas por micróbios patogênicos e parasitas (Chisholm et al., 2006).

Recentes trabalhos têm indicado que os PRRs desempenham um papel crucial na ativação das células da glia na medula espinal através da indução e manutenção da dor crônica neuropática (Nicotra et al., 2012). Já foi descrito que a expressão aumentada de TLR4 na medula se correlaciona temporariamente com o desenvolvimento da hipersensibilidade mecânica e térmica após lesão de nervos periféricos. Além disso, a expressão espinal de CD11b e GFAP é diminuída em animais neuropáticos deficientes para TLR4, indicando redução da ativação glial nesses animais (Tanga et al., 2005; Cao et al., 2009; Kuang et al., 2012). Também, animais deficientes para TLR2 apresentam uma redução na dor crônica neuropática, fato associado a uma redução da gliose e nas concentrações de citocinas próinflamatórias liberados por essas células (Kim et al., 2007).

Sabe-se que neurônios sensitivos de primeira ordem lesados podem liberar moléculas da matriz extracelular e DAMPs, como o grupo de proteínas de alta mobilidade B1 (HMGB1), fibronectina e as proteínas de choque térmico HSP60 e HSP90, os quais induzem a ativação de TLRs e estão implicados na modulação da dor (Grace et al., 2014). Exemplificando, a expressão neuronal de HMGB1 é aumentada na medula espinal após a indução de lesão nervosa periférica, e correlaciona-se com o desenvolvimento de alodinia tanto no câncer ósseo como na neuropatia diabética. Porém, essa hiperalgesia pode ser atenuada pela administração de um inibidor de HMGB1(Kuang et al., 2012; Ren et al. 2012; Tong et al., 2010). Já a fibronectina tem 
sido associada a um aumento na expressão do receptor P2X4 nas células microgliais espinais (Inoue \& Tsuda, 2012). Além disso, após a indução de neuropatia periférica, tem sido demonstrado que HSP60 é altamente expressa na medula espinal e que a inibição de HSP90 é capaz de reverter o processo neuropático instalado (Hutchinson et al., 2009; Zou et al., 2012). Portanto, ativação desses receptores, via DAMPs, tem sido fortemente hipotetizado como sendo a fonte de ativação desses receptores em condições de dor neuropática onde nenhum componente infecioso foi descrito (Nicotra et al., 2012; Grace et al., 2014).

Além dos receptores TLRs, as células da glia também expressam receptores do tipo NLRs. Guo et al. (2006) demonstraram que a co-estimulação dos receptores TLRs e NLRs induzem ativação da micróglia levando a um aumento da expressão de P2X4 e, consequentemente, liberação de substâncias pró-inflamatórias.

\subsection{Receptores NOD1 e NOD2}

Os primeiros sensores intracelulares de PAMPs da família NLRs a serem descobertos foram NOD1 (CARD4) e NOD2 (CARD15) (Inohara et al., 1999; Ogura et al., 2001). Esses receptores caracterizam-se por três domínios distintos: domínio do tipo repetições ricas em leucina (LRR) na região C-terminal, envolvido no reconhecimento do ligante; um domínio central NOD (também conhecido como NACHT ou NBD), que facilita a auto-oligomerização e possui atividade ATPase; e, na região N-terminal, um domínio efetor de recrutamento de caspase (CARD) para NOD1 e dois domínios CARD para NOD2 (Meylan et al., 2006; Strober et al., 2006).

Os NLRs foram identificados em células imunes e não-imunes. NOD1 é amplamente expresso em muitos tipos de células e órgãos, já a expressão do NOD2 
parece ser mais restrita, tendo sido descrita em macrófagos (Ogura et al., 2001), células dendríticas (Inoharaet al., 2005), células de Paneth (Ogura et al., 2001), queratinócitos (Voss et al., 2006), células epiteliais do intestino (Hisamatsu et al., 2003), pulmão (Uehara et al., 2007), cavidade oral (Uehara et al., 2005) e osteoblastos (Marriott et al., 2005).

Além disso, existem evidências na literatura que correlacionam a presença desses receptores também em células da glia. Zheng e colaboradores (2012) sugeriram a possibilidade da micróglia expressar NOD1, uma vez que foi demonstrado que LPS é capaz de induzir culturas de micróglia a liberarem citocinas pró-inflamatórias através da via NOD1-NF-kB. Já Sterka e colaboradores (2006), demonstraram que culturas de astrócitos expressam níveis constitutivos de NOD2 e que após exposição a bactérias patogênicas do SNC, a expressão de NOD2, assim como de sua proteína adaptadora RIPK2, são aumentadas. Além disso, outros recentes trabalhos demonstraram e ratificaram que, micróglia e astrócitos expressam NOD2, após infecção por diferentes bactérias patogênicas (Chauhan et al., 2009; Liu et al., 2010a, b).

Os receptores NOD1 e NOD2 são capazes de detectar moléculas bacterianas produzidas durante a síntese, degradação e remodelação do peptideoglicano (PGN), o principal componente da parede celular bacteriana (McDonald et al., 2005). O NOD2 detecta muramil dipeptídeo (MDP), encontrado no PGN de bactérias gram-positivas e gram-negativas (Girardin et al., 2003b; Inohara et al., 2003), enquanto o NOD1 reconhece o $\gamma$-D-meso-glutamil-ácido diaminopimélico (iE-DAP), contido nos fragmentos de PGN de bactérias gram-negativas e de certas bactérias gram-positivas (Chamaillard et al., 2003; Girardin et al., 2003a; Hasegawa et al., 2006).

Após a detecção microbiana, NOD1 e NOD2 recrutam diretamente a serina- 
treonina quinase RIPK2 (também conhecida como proteína 2 de interação com o receptor RIP2, RICK, CARDIAK e CCK) através de interações CARD-CARD (Inohara et al., 1999; Ogura et al., 2001). A ativação de RIPK2 leva a

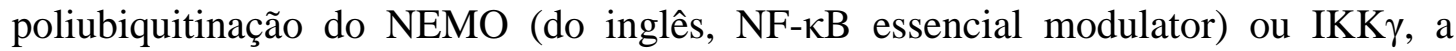
subunidade regulatória do complexo de protéina quinase IKK, e consequente ativação das subunidades catalíticas de IKK (IKK $\alpha$ e IKK $\beta)$. Esta por sua vez, fosforila o IкB (proteína inibitória da família kappa $\mathrm{B}$ ), levando a degradação proteossomal e liberação de fator nuclear $\kappa \mathrm{B}(\mathrm{NF}-\kappa \mathrm{B})$ para translocação em direção ao núcleo. Além da ativação de $\mathrm{NF}-\kappa \mathrm{B}$, a sinalização desses receptores também dá origem à ativação de MAPKs. A ativação de ambas as vias leva a transcrição de numerosos genes, contribuindo para a defesa do hospedeiro via produção de citocinas pró-inflamatórias e moléculas antimicrobianas (Caruso et al., 2014; Inohara et al., 2000; Abbott et al., 2004; Strober et al., 2006).

Confirmando a importância da sinalização destes receptores via RIPK2, células provenientes de animais deficientes para a molécula RIPK2 não são capazes de ativar NF-кB após estímulo com os ligantes de NOD1 ou NOD2 (Kobayashi et al., 2002). A ilustração abaixo demonstra a via de sinalização de NOD1 e NOD2 e os eventos subjacentes à ativação por seus respectivos ligantes, iE-DAP e MDP. 


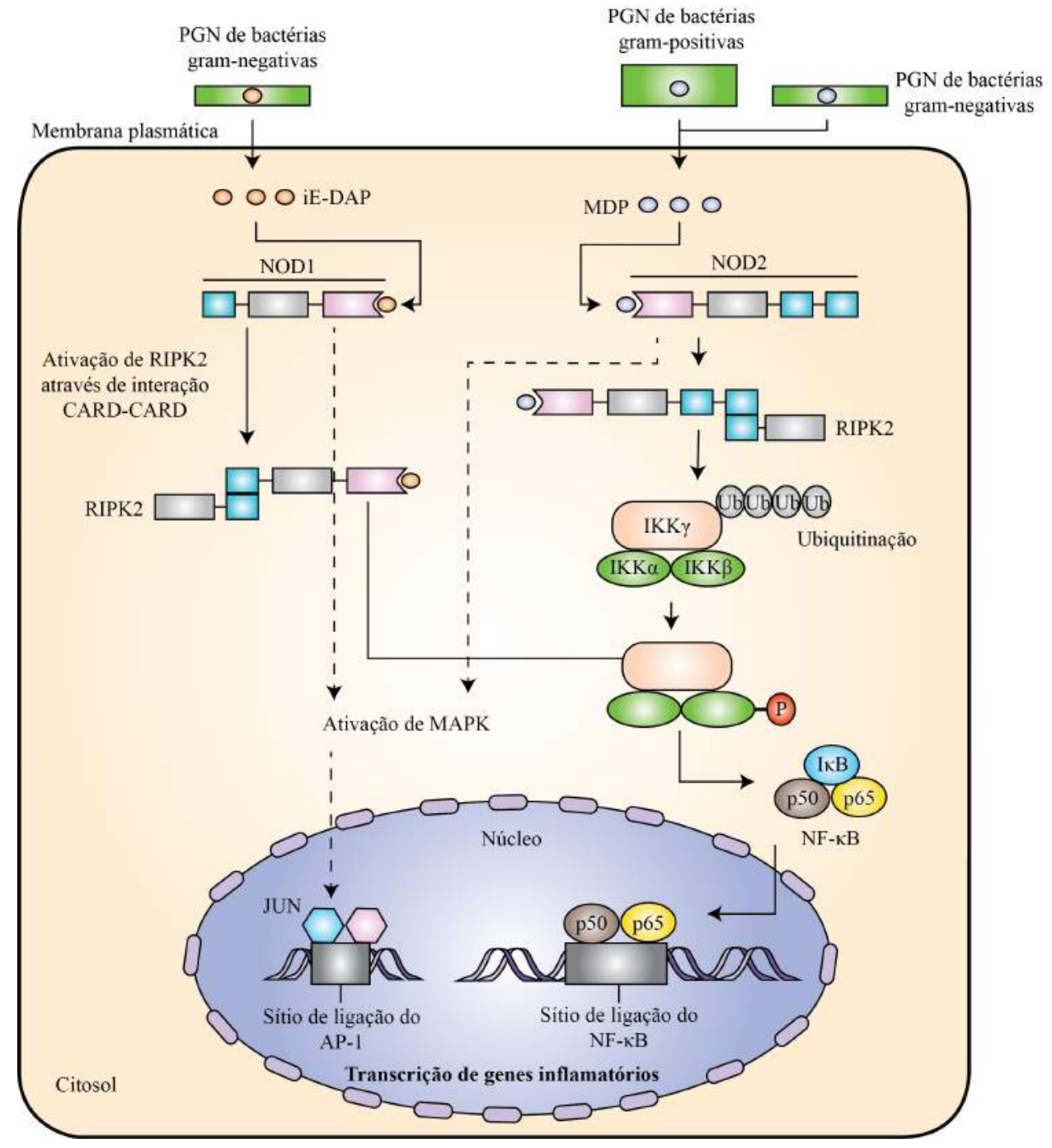

Ilustração 1. Via de sinalização de NOD1 e NOD2. O reconhecimento dos ligantes iE-DAP e MDP, através dos domínios LRRs, ativa NOD1 e NOD2 respectivamente, que então recruta RIPK2, através de interações CARD-CARD. A ativação de RIPK2 leva a poliubiquitinação do NEMO e consequente ativação das subunidades catalíticas IKK $\alpha$ e IKK $\beta$. Isso é seguido pela fosforilação de IKK $\beta$, bem

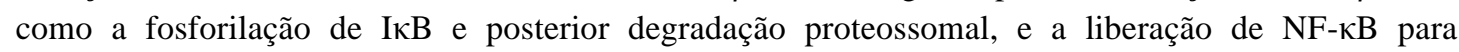
translocação em direção ao núcleo onde atuará na transcrição de genes específicos. Além da ativação de NF- $\kappa$ B, a sinalização de NOD1 e NOD2 também dá origem à ativação de MAPKs, tais como JNK, ERK e p38 MAPK (indicado por setas tracejadas). Modificado de Strober et al., 2006.

A desregulação da função dos receptores NOD1 e NOD2 já foi descrita numa variedade de desordens, incluindo inflamações crônicas, auto-imunidade e predisposição ao câncer (Carneiro et al., 2008; Davis et al., 2011). Porém, pouco ainda se sabe sobre os possíveis mecanismo de regulação nas diferentes doenças. Dessa maneira, os recentes interesses no estudo desses receptores foram gerados pela associação de mutações nesses receptores com variadas doenças em humanos. 
Com relação ao NOD2, podemos citar desordens inflamatórias crônicas, como doença de Crohn, uma doença inflamatória comum do trato intestinal, que apresenta mutação na região LRR (Ogura et al., 2001b; Hugot et al., 2001), e a síndrome de Blau, um traço autossômico dominante que é caracterizado por artrite, uveíte e erupções cutâneas, e que apresenta mutação na região NBD (Miceli-Richard et al., 2001; Wang et al., 2002). Além disso, polimorfismos em NOD2 também têm sido associados a outras doenças como eczema e dermatite atópica (Macaluso et al., 2007), sarcoidose de início precoce (Kanazawa et al., 2005), artrite (Joosten et al., 2008; Vieira et al., 2012), asma (Duan et al, 2010) e câncer de próstata, endometrial e coloretal (Ashton et al., 2010; Kang et al., 2012; Couturier-Maillard et al., 2013). Quanto ao NOD1, estudos indicam que pacientes com variação genética nesse gene apresentam uma maior susceptibilidade a sarcoidose (Tanabe et al., 2006), risco elevado de desenvolver asma e dermatite atópica (Hysi et al., 2005) e também associações a diferentes modelos de câncer (Chen et al., 2008; Kang et al., 2012).

Nos últimos anos, inúmeros avanços têm sido alcançados no que diz respeito aos mecanismos moleculares que participam na indução e manutenção da dor crônica, incluindo ativação glial. Já foi demonstrado que alguns TLRs participam desse processo e, em modelos de inflamação/infecção do SNC, os receptores TLRs e NLRs cooperam na ativação das células da glia. Essas evidências nos levaram a hipotetizar que os receptores NOD1 e NOD2 possam ser importantes para a ativação de células gliais e, consequentemente, contribuir para a hipersensibilidade observada em modelos de dor crônica. Neste sentido, resultados prévios de nosso grupo de pesquisa demonstraram que camundongos selvagens tratados com uma injeção intratecal de MDP, mas não com iE-DAP, apresentaram hipersensibilidade mecânica comparado com o grupo controle acompanhado de um aumento na expressão do RNAm de IL-1 $\beta$, 
IL-6 e TNF- $\alpha$ na medula espinal. Além disso, esse efeito não foi observado em animais deficientes para NOD2 e RIPK2 e nos animais tratados com inibidores gliais (Ferreira et al., dados não publicados). Portanto, diante de todas as evidências, o envolvimento dos receptores NOD1 e NOD2, via RIPK2, na gênese da dor crônica foi investigado. 
Objetivos 


\section{Objetivos}

\subsection{Objetivo geral}

Investigar o papel dos receptores NOD1 e NOD2 na gênese da dor crônica neuropática, focando na sua via de sinalização (RIPK2), liberação de citocinas prónociceptivas e ativação de células gliais.

\subsection{Objetivos específicos}

2.2.1. Determinar a expressão e localização dos receptores NOD1 e NOD2 na medula espinal;

2.2.2. Verificar a nocicepção térmica e química em animais selvagens e deficientes para os receptores NOD1 e NOD2;

2.2.3. Avaliar a hipersensibilidade nociceptiva mecânica após a indução de lesão de nervos periféricos e inflamação periférica em animais selvagens e deficientes para os receptores NOD1e NOD2;

2.2.4. Determinar o perfil de indução de citocinas pró-inflamatórias e ativação de células gliais na medula espinal, em animais selvagens e deficientes para NOD1 e NOD2, após indução de neuropatia periférica; 
2.2.5. Avaliar o perfil de liberação de citocinas pró-inflamatórias em culturas primárias de micróglia estimuladas por agonistas de NOD1 (iE-DAP), NOD2 (MDP) e TLR4 (LPS);

2.2.6. Determinar a contribuição da via de sinalização dependente de RIPK2 na hipersensibilidade mecânica, indução de citocinas pró-inflamatórias e ativação das células gliais na medula espinal, em animais selvagens e deficientes para RIPK2, após indução de neuropatia periférica;

2.2.7. Determinar o perfil de expressão de P2X4 na medula espinal, em animais selvagens e deficientes para NOD1, NOD2 e RIPK2, após indução de neuropatia periférica;

2.2.8. Determinar a contribuição do infiltrado de células periféricas derivada da medula óssea na ativação microglial mediada por NOD1 e NOD2, após indução de neuropatia periférica;

2.2.9. Avaliar o papel do infiltrado de células periféricas derivada da medula óssea na hipersensibilidade nociceptiva mediada por NOD1 e NOD2, após indução de neuropatia periférica. 
Material e métodos 


\section{Material e métodos}

\subsection{Animais}

Foram utilizados camundongos machos e fêmeas C57BL/6 selvagens (WT) ou deficientes $\left(^{-/}\right)$para NOD1, NOD2 e RIPK2, bem como camundongos transgênicos que expressam a proteína fluorescente verde (GFP-total), provenientes do Biotério Central da Universidade de São Paulo, Campus de Ribeirão Preto (USP-RP) e do Centro de Criação de Camundongos Especiais da Faculdade de Medicina de Ribeirão Preto (FMRP-USP). Os camundongos possuíam entre cinco e sete semanas de idade, pesavam aproximadamente 20-25 g, e foram mantidos no biotério de manutenção do Departamento de Farmacologia da FMRP-USP, sob condições de temperatura (23$25^{\circ} \mathrm{C}$ ) e ciclo claro/escuro (12 horas) controlados, com livre acesso à ração e água até o dia do experimento. Todos os protocolos experimentais realizados neste trabalho foram conduzidos de acordo com as normas de ética estabelecidas para experimentação com animais, recomendadas pela IASP (Associação Internacional para o Estudo da Dor) (Zimmermann, 1983), e avaliados pela Comissão de Ética em Experimentação Animal (CETEA) da FMRP-USP (protocolo n 106/2011).

\subsection{Drogas}

As drogas foram adquiridas das seguintes fontes: MDP (Sigma-Aldrich, EUA), iE-DAP (InvivoGen , USA), LPS de Escherichia coli 0111:B4 (Sigma-Aldrich „EUA), formaldeído (Merck, Germany) e CFA (Sigma-Aldrich, EUA). Todas as drogas foram dissolvidas em água estéril sendo que as doses selecionadas foram 
baseadas em prévias padronizações.

\subsection{Modelo experimental de dor neuropática}

O modelo experimental de dor neuropática utilizado neste estudo foi inicialmente descrito em ratos (Decosterd \& Woolf, 2000) e em seguida em camundongos (Shields et al., 2003). Após anestesia inalatória (isoflurano a 2\%), a pele da superfície lateral da coxa traseira dos animais passou por antissepsia e em seguida foi incisionada, e o músculo femoral divulsionado, expondo as três ramificações do nervo isquiático (peroneal comum, tibial e sural, Ilustração 2).

A execução da técnica consiste na amarração (fio de sutura 5-0) e imediata transecção das ramificações peroneal comum e tibial do nervo isquiático, sendo removida uma porção de aproximadamente $1,5 \mathrm{~mm}$. A ramificação sural do nervo isquiático permanece intacta, preservada, por isso esse modelo é denominado Spared Nerve Injury (SNI). Em seguida, o músculo e a pele foram suturados com fio de sutura adequado.

O grupo experimental controle foi composto por animais falsamente operados (Sham), ou seja, foi realizada incisão na pele, divulsionamento do músculo femoral e exposição do nervo isquiático de modo similar ao grupo SNI, porém sem qualquer manipulação desse nervo. A seguir, o músculo e a pele foram suturados. 


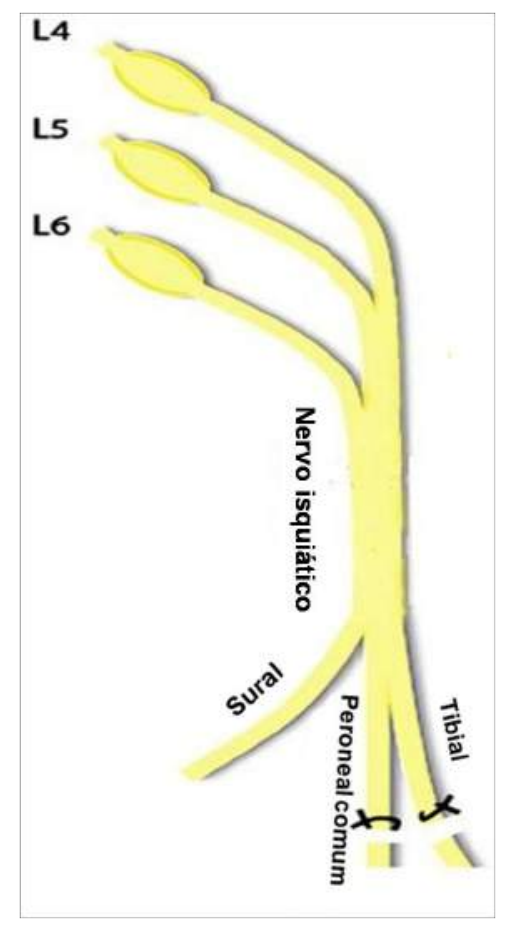

Ilustração 2. Esquema do modelo experimental de dor neuropática SNI. A figura demonstra as ramificações eferentes na medula espinal dos segmentos lombares L4, L5 e L6 formando o nervo isquiático, o qual se ramifica, inicialmente, nos nervos tibial, peroneal comum e sural. Os dois primeiros são amarrados e cortados e o último, preservado. Adaptado de Calvo e Bennett, 2012.

\subsection{Modelo experimental de dor inflamatória}

Para induzir a resposta inflamatória persistente, os animais receberam injeção intraplantar de $10 \mu \mathrm{L}$ de adjuvante completo de Freund (CFA: $1 \mathrm{mg} / \mathrm{mL}$ de bacilo de Mycobacterium tuberculosis inativado por calor; cada mililitro $(\mathrm{mL})$ de veículo contém $0,85 \mathrm{~mL}$ de óleo de parafina $+0,15 \mathrm{~mL}$ monooleato de manida) na superfície plantar da pata direita traseira (Cao et al., 1998; Quintão et al., 2005).

\subsection{Avaliação nociceptiva}

Os testes nociceptivos foram realizados entre 8:00 e 17:00 h. 


\subsubsection{Teste de nocicepção mecânica: filamentos de von Frey}

A avaliação da hipersensibilidade nociceptiva mecânica em camundongos foi realizada como previamente descrito por Cunha et al. (2004), utilizando filamentos de von Frey (North Coast Medical, Inc. Morgan Hill, CA). Os animais foram acondicionados em caixas de acrílico, cujo assoalho é constituído por uma rede de malha de arame não maleável, 15-30 minutos antes do experimento, para ambientação.

Essa técnica utiliza uma série de monofilamentos de náilon para medir limiares de força dentro de um conjunto de 20 monofilamentos com aumento da rigidez $(0,008 \mathrm{~g}$ a $300 \mathrm{~g}$ de força). Para avaliação em camundongos foram utilizados filamentos de 0,008 à $2 \mathrm{~g}$, os quais foram aplicados perpendicularmente, sobre a região lateral da parte plantar da pata traseira dos animais, por um período aproximado de 3 segundos ou até que o animal demonstre comportamento nociceptivo, caracterizado por flexão seguida de retirada da pata, "flinch". Essa região é inervada pelo ramo sural do nervo isquiático, o qual não sofre qualquer tipo de manipulação neste modelo experimental. Portanto, consiste em uma região crítica no desenvolvimento da neuropatia, e, por esse motivo, é a região avaliada pelos filamentos (Richner et al., 2011). Assim sendo, o filamento de menor força capaz de induzir resposta foi determinado como sendo o limiar mecânico de retirada (log mg ).

\subsubsection{Teste de nocicepção química: formalina}

Os camundongos receberam administração subplantar de $10 \mu \mathrm{l}$ de uma solução de formalina $1 \%$ na pata direita traseira. Em seguida, foi cronometrado o 
tempo que o animal lambe, sacode (comportamento conhecido como "flinch") ou morde a pata traseira a cada 5 minutos durante um período total de 50 minutos. Esse teste é dividido em duas fases, sendo a primeira de 0 a 10 minutos e a segunda de 10 a 50 minutos após aplicação da formalina (Hunskaar \& Hole, 1987). Os resultados foram expressos como tempo de resposta em segundos em relação a $1^{\text {a }}$ fase $(0-10$ $\min )$ e $2^{\mathrm{a}}$ fase $(10-50 \mathrm{~min})$

\subsubsection{Teste de nocicepção térmica: placa quente}

Os animais foram colocados individualmente no equipamento que consiste de uma placa quente aquecida a diferentes temperaturas $\left(52^{\circ} \mathrm{C}\right.$ e $\left.56^{\circ} \mathrm{C}\right)$ e as respostas ao estímulo térmico (retirada e lambida das patas traseiras) cronometradas. Os resultados foram expressos como a latência para o aparecimento desta resposta em segundos (Kuraishi et al., 1983).

\subsection{Western Blotting}

\subsubsection{Preparação das amostras de medula espinal: extração das proteínas}

Nos tempos determinados em cada protocolo experimental, os animais foram anestesiados (isoflurano 2\%), sacrificados e amostras da medula espinal (região L4, L5 e L6, lado ipsilateral) foram coletadas e estocadas a $-70{ }^{\circ} \mathrm{C}$ em $300 \mu \mathrm{L}$ de tampão RIPA $^{\circledR}($ Sigma-Aldrich) com inibidores de proteases (Protease Inhibitor Cocktail, Pierce, Rockford, IL, USA). Todas as amostras foram homogeneizadas com o auxílio de um homogeneizador (IKAT 10 basic ultra-turrax). O homogenato foi centrifugado 
a $13000 \mathrm{~g}$ durante 15 minutos a $4{ }^{\circ} \mathrm{C}$. Uma alíquota do sobrenadante foi separada para dosagem de proteínas pelo método colorimétrico Coomassie (Bradford) Protein Assay Kit (Pierce, Rockford, IL, USA).

\subsubsection{Eletroforese e ImunoBlotting}

Amostras do homogenato foram desnaturadas a $100{ }^{\circ} \mathrm{C}$ durante 4 minutos. Em seguida, as amostras foram aplicadas (40 $\mu$ g por grupo para NOD1 e NOD2) em gel de poliacrilamida (1,5 $\mathrm{mm}$ de espessura) na presença de SDS (SDS-PAGE) para separação por eletroforese, utilizando-se o sistema Mini-Protean II Eletrophoresis Cell (Bio-Rad Laboratories, Hercules CA, USA). O gel de entrada foi de acrilamida/ bisacrilamida 30\%, Tris-HCl 0,5 M, pH 8,8 e SDS 10\%. O gel de separação foi de acrilamida/ bisacrilamida 30\%, Tris- $\mathrm{HCl} 1,5 \mathrm{M}, \mathrm{pH}$ 6,8 e SDS 10\%. A porcentagem do gel de separação foi determinada a partir do peso molecular de cada uma das proteínas analisadas e foi a seguinte: NOD1 (95 kDa) 8\% e NOD2 (115 kDa) 8\%.

A corrida foi feita sob voltagem constante $100 \mathrm{~V}$, utilizando-se o tampão de corrida Tris- $\mathrm{HCl} 25 \mathrm{mM}$, glicina $250 \mathrm{mM}$ pH 8,3, e SDS 10\%. As proteínas separadas por SDS-PAGE foram transferidas para membranas de nitrocelulose $0,2 \mu \mathrm{m}$ (Amersham Pharmacia Biotech, Little Chalfont, UK) utilizando-se o sistema de transferência Trans-Blot Turbo (Bio-Rad Laboratories, Hercules CA, USA). Após o fracionamento das proteínas, o gel e a membrana de nitrocelulose foram incubados no tampão de transferência (Tris-HCl 25 mM, pH 8,3, glicina 192 mM, 20\% de metanol) por 10 minutos. A transferência foi realizada sob voltagem constante de $25 \mathrm{~V}$, amperagem de 2,5 A durante 30 minutos.

Após a transferência, as membranas foram coradas com Ponceau 0,5\% para 
certificação de que houve transferência das proteínas. Em seguida, as membranas foram lavadas em solução tampão salina Tris (TBS) contendo 0,1\% tween 20 (TBST) e o bloqueio dos sítios antigênicos inespecíficos pela incubação das membranas “overnight" (NOD1, NOD2 e $\beta$-actina) a $4^{\circ} \mathrm{C}$ em solução TBS-T contendo: a) $2 \%$ de BSA $+7 \%$ de leite desnatado (NOD2 e $\beta$-actina); b) $5 \%$ de BSA (NOD1), sob agitação contínua.

Após o bloqueio, as membranas foram lavadas 3 vezes com TBS contendo 0,1\% de Tween 20 por 5 minutos, e em seguida incubadas "overnight" na mesma solução em que o bloqueio foi realizado, e adicionado o anticorpo primário: a) antiNOD1 1:500 (Cell Signaling), anti-NOD2 1:200 (Santa Cruz) e anti- $\beta$ actina 1:5000 (Millipore). Após a incubação com o anticorpo primário, as membranas foram lavadas 3 vezes por 5 minutos com TBS contendo 0,1\% Tween 20 e, logo após, incubadas com os anticorpos secundários: anti-rabbit conjugado à peroxidase 1:3000 (KPL) e anti-mouse conjugado à peroxidase 1:5000 (KPL) por 1 hora, a temperatura ambiente. Após esta incubação, as membranas foram novamente lavadas 3 vezes com TBS contendo $0,1 \%$ Tween 20 por 5 minutos.

Para a revelação as membranas foram incubadas com uma mistura de reagentes do kit de quimioluminescência (Amersham ECL Prime Western Blotting Detection Reagent) como descrito no manual de instruções. As membranas foram reveladas através do Molecular Imager Chemi Doc TM XRS+ Bio Rad conforme instrução do fabricante. Os resultados foram demonstrados como expressão da proteína em questão relativa à expressão da $\beta$-actina, controle endógeno. 


\subsection{Avaliação da expressão gênica}

\subsubsection{Processamento das amostras e extração de RNA mensageiro (RNAm)}

As amostras de medula espinal (entre as região L3, L4 e L5, lado ipsilateral) foram coletadas em $750 \mu \mathrm{L}$ de Trizol (Sigma-Aldrich) e homogeneizadas com o auxílio de um homogeneizador (IKAT 10 basic ultra-turrax). A extração do RNA total foi realizada como se segue: para cada $750 \mu \mathrm{L}$ de suspensão (tecido + Trizol), foram adicionados 0,2 $\mathrm{mL}$ de clorofórmio (Merck). As amostras foram centrifugadas a $14000 \mathrm{rpm}$ por 15 minutos a $4^{\circ} \mathrm{C}$ e a fase aquosa, contendo RNA, foi transferida para outro tubo, e adicionado $500 \mu \mathrm{L}$ de isopropanol (Merck) gelado. Os tubos contendo as amostras foram agitados no vórtex e incubados por 15 minutos a $-20^{\circ} \mathrm{C}$.

Posteriormente, as amostras foram novamente centrifugadas a $14000 \mathrm{rpm}, 15$ minutos a $4^{\circ} \mathrm{C}$. Após este procedimento, o líquido sobrenadante foi descartado cuidadosamente, ficando aderido aos tubos o precipitado de RNA. Nele foi adicionado $1000 \mu \mathrm{L}$ de álcool a 75\% (preparado com água livre de DNAse e RNAse e álcool absoluto), e agitados no vórtex. As amostras foram posteriormente centrifugadas a $7000 \mathrm{rpm}$ por 10 minutos a $4{ }^{\circ} \mathrm{C}$. O sobrenadante foi descartado e o precipitado de RNA ressuspendido em $10 \mu \mathrm{L}$ de água (Sigma-Aldrich). A concentração de RNA foi determinada através da densidade ótica no comprimento de onda de 260nm, por meio do aparelho NanoVue Plus ${ }^{\circledR}$ GE. 


\subsubsection{Síntese de DNA complementar (cDNA) e Reação em Cadeia da Polimerase- Transcriptase Reversa em Tempo Real (RT-qPCR)}

O RNAm foi transcrito para cDNA, através da seguinte reação: $2 \mu \mathrm{g}$ de amostra de RNAm $+1 \mu \mathrm{L}$ de Oligo DT (Sigma-Aldrich) e água (Sigma-Aldrich) q.s.p $7 \mu \mathrm{L}$. A solução foi levada ao termociclador (Eppendorf Mastercycle Gradiente) a $70^{\circ} \mathrm{C}$ por 5 minutos e $5^{\circ} \mathrm{C}$ durante 1 minuto. Em seguida, foi adicionado um mix de reagentes contendo: $1 \mu \mathrm{L}$ de DNTP $(10 \mathrm{mM}), 4 \mu \mathrm{L}$ de Buffer $5 \mathrm{X}, 2,4 \mu \mathrm{L}$ de $\mathrm{MgCl} 2$ (25mM), $1 \mu \mathrm{L}$ transcriptase reversa Pre-Improm II (Promega) e água (Sigma-Aldrich) q.s.p para $13 \mu \mathrm{L}$. Deu-se continuidade a reação em $25^{\circ} \mathrm{C}$ por 5 minutos, $42^{\circ} \mathrm{C}$ por 60 minutos e $70{ }^{\circ} \mathrm{C}$ durante 15 minutos.

A qPCR foi executado com volume final de $6,25 \mu \mathrm{L}$ para cada tubo, contendo $3,125 \mu \mathrm{L}$ SYBR-Green ${ }^{\circledR}$ (Invitrogen) $+0,25 \mu \mathrm{L}$ de primer (sequência sense) $+0,25$ $\mu \mathrm{L}$ primer (sequência anti-sense) $+0,0125 \mu \mathrm{L}$ de $\operatorname{Rox}^{\circledR}$ (Invitrogen) $+1,6125 \mu \mathrm{L}$ de água (Sigma-Aldrich) $+1 \mu \mathrm{L}$ de amostra de cDNA. A placa, onde esses reagentes e amostras foram pipetadas, foi acondicionada em aparelho adequado (ViiATM 7 RealTime PCR System - Life Technologies) e mantida a $95^{\circ} \mathrm{C}$ (10 minutos), e mais 40 ciclos de $94^{\circ} \mathrm{C}$ ( 1 minuto), $56^{\circ} \mathrm{C}$ ( 1 minuto $)$ e $72^{\circ} \mathrm{C}$ ( 2 minutos $)$.

A curva de dissociação foi analisada a $65-95^{\circ} \mathrm{C}$, para verificar se apenas um produto foi amplificado. As amostras que tiveram mais de um pico foram excluídas. Os resultados foram analisados através do método comparativo de "Cycle Threshold" (CT). Os níveis de expressão relativa dos genes alvos foram normalizados com base na expressão de GAPDH como controle endógeno. As sequências dos pares de primers (camundongo) utilizados estão demonstradas na tabela abaixo: 
Tabela 1: Sequência dos pares de primers

\begin{tabular}{ccc}
\hline Primers & Sequência sense & Sequência antisense \\
\hline GADPH & CATCTTCTTGTGCAGTGCCA & CGGCCAAATCCGTTCAC \\
P2X4 & GCGTCTGTGAAGACCTGTGA & GATTTGGCCAAGACGGAATA \\
IBA-1 & TGAGGAGCCATGAGCCAAAG & GCTTCAAGTTTGGACGGCAG \\
NOD1 & CATGATCCAGCAAAGCAATA & CCATACCCTTCTTCTCATCCAACT \\
NOD2 & AACTGTCCAACAATGGCATCAC & TTCCCTCGAAGCCAAACCT \\
GFAP & AGGGCGAAGAAAACCGCATCACC & TCTAAGGGAGAGCTGGCAGGGCT \\
\hline
\end{tabular}

\subsection{Imunofluorescência- Free Floating}

Após anestesia (isoflurano 2\%), os animais foram perfundidos com solução salina $0,9 \%$ seguido de paraformaldeído $4 \%$ (PFA) em pH 7,3-7,4. Em seguida a medula espinal foi extraída a nível de L4, L5 e L6 (bilateral). Os tecidos foram pósfixados em solução de PFA 4\% por 2 horas e overnight em sacarose $30 \%$. No dia seguinte, as medulas foram incluídas em meio para congelamento Tissue-Tek® O.C.T. ${ }^{\text {TM }}$ (Sakura Finetek), rapidamente congeladas em gelo seco e estocadas a $70^{\circ} \mathrm{C}$. Os cortes (secções) foram realizados em criostato (Leica CM1850, Alemanha) com espessura de $60 \mu \mathrm{m}$ e estocados em $2 \mathrm{~mL}$ de PBS.

Para execução da técnica, primeiramente, as secções foram lavadas 3 vezes em PBS por 5 minutos cada lavagem e incubados em solução de glicina $0,1 \mathrm{M}$ por 30 minutos, para retirada completa de grupos aldeídos. Novamente, os cortes foram lavados em PBS (3 vezes de 5 minutos) e em seguida realizou-se o bloqueio de ligações inespecíficas, pela incubação com solução de BSA $1 \%$ e Triton X $0,1 \%$ 
diluídos em PBS, por 1 hora. Após o bloqueio, os cortes foram incubados com os seguintes anticorpos primários: anti-IBA-1 produzido em coelho 1:1000 (Wako), antiNOD1 produzido em cabra 1:50 (Santa Cruz), anti-NeuN conjugado com Alexa 488 produzido em coelho 1:500 (Millipore), anti-GFP produzido em coelho 1:1000 (Life Technologies). Todos os anticorpos foram diluídos na solução de bloqueio e mantidos overnight a $4^{\circ} \mathrm{C}$, sob constante agitação.

Após esta etapa, os cortes foram novamente lavados em PBS (3 vezes de 5 minutos), seguindo-se da incubação dos anticorpos secundários fluorescentes apropriados: anti-coelho marcado com Alexa 488 (1:1000, Life Technologies), anticoelho marcado com Alexa 594 (1:1000, Invitrogen), anti-cabra marcado com Alexa 594 (1:100, Invitrogen) por 1 hora, em temperatura ambiente e sob constante agitação. Posteriormente as secções foram lavadas (3 vezes de 5 minutos) e estendidas sobre lâminas gelatinizadas montadas em Fluormount ${ }^{\mathrm{TM}}$ (Southern Biotech). As imagens foram obtidas em microscopia confocal (SP5, Leica, Wetzlar, Alemanha).

Para a quantificação da intensidade de fluorescência, utilizou-se o programa ImageJ $1.47 \mathrm{v}$ (National Institutes of Health, EUA). Para isso, foram escolhidas áreas delimitadas em quatro regiões específicas de interesse: lado ipsilateral da lesão no corno dorsal (CDi) e ventral da medula espinal (CVi) além do lado contralateral da lesão no corno dorsal $(\mathrm{CDc})$ e ventral da medula espinal $(\mathrm{CVc})$. A intensidade da fluorescência total corrigida (FTC) de 3 secções por camundongo, 4 animais por grupo, foi calculado pela seguinte fórmula: FTC $=$ Densidade integrada - (área delimitada $\mathrm{X}$ fluorescência média do background) 


\subsection{Cultura primária de micróglia}

Cérebros de camundongos C57BL/6 neonatos com 1 dia foram utilizados para preparar culturas de células microgliais primárias (Ribes et al., 2012). Após a remoção das meninges, os cérebros foram cuidadosamente coletados e suspensos em meio de Eagle modificado por Dulbecco (DMEM) (Gibco) suplementado com 10\% de soro fetal bovino inativado (Biowest) e 1\% penicilina-estreptomicina (Gibco). Em seguida, foram triturados através de múltiplas pipetagens com pipeta de Pasteur e centrifugados $1000 \mathrm{rpm}$ por 5 minutos a $4^{\circ} \mathrm{C}$. As células foram adicionadas a uma densidade de 2 cérebros por garrafa de cultura média e mantidas a $37^{\circ} \mathrm{C}$ e $5 \%$ de $\mathrm{CO}_{2}$. O meio de cultura foi trocado em 48 horas e depois, somente no $14^{\circ}$ dia foi adicionado mais meio de cultura. Após 16 a 18 dias do início da cultura, as células microgliais foram tripsinizadas (0.05\% tripsina-EDTA) (Gibco), centrifugadas a 1000 rpm por 5 min e plaqueadas numa densidade de $10^{5}$ células/poço (placa de 48 poços).

\subsection{Estimulação microglial}

As culturas primárias de micróglia foram estimuladas com diferentes concentrações de LPS (0,1-1000 ng/mL), MDP (1-10 $\mu \mathrm{g} / \mathrm{mL})$ e iE-DAP (10-1000 $\mathrm{ng} / \mathrm{mL})$ e co-estimuladas por MDP $(3 \mu \mathrm{g} / \mathrm{mL})+$ LPS $(0,1 \mathrm{ng} / \mathrm{mL})$ e iE-DAP (100 $\mathrm{ng} / \mathrm{mL})+$ LPS $(0,1 \mathrm{ng} / \mathrm{mL})$. Após 48 horas de estimulação, os sobrenadantes foram coletados e submetidos à análise do perfil de liberação de citocinas pró-inflamatórias por ELISA. 


\subsection{Quantificação de citocinas pelo método de ELISA}

As concentrações de interleucina (IL)-1 $\beta$ e IL-6, fator de necrose tumoral alfa (TNF- $\alpha$ ), e quimiocina derivada de queratinócito $(\mathrm{KC})$ foram determinadas pelo ensaio imunoenzimático ELISA (enzime-linked immunosorbent assay) utilizando o sobrenadante de culturas de células primárias de micróglia ou amostras da medula espinal (região L4, L5 e L6). O ensaio foi realizado baseado em protocolo previamente descrito (Taktak et al., 1991).

As amostras de medula espinal foram homogeneizadas com o auxílio de um homogeneizador (IKAT 10 basic ultra-turrax). O homogenato foi centrifugado a 13000 g durante 15 minutos a $4{ }^{\circ} \mathrm{C}$ e o sobrenadante utilizado para avaliar os níveis das citocinas. Placas de 96 poços foram recobertas com $50 \mu \mathrm{l} /$ poço dos anticorpos anti-TNF- $\alpha$, anti-IL-1 $\beta$, anti-KC ou anti-IL-6, os quais foram diluídos em PBS e incubados overnight a $4^{\circ} \mathrm{C}$.

Após esse período, a placa foi lavada de 3 a 5 vezes com PBS contendo $0,05 \%$ Tween 20 (PBS-T). As ligações não específicas foram bloqueadas com $50 \mu \mathrm{l}$ de solução de bloqueio (1\% BSA em PBS), durante 1 hora à temperatura ambiente. A placa foi lavada, conforme descrito acima, e, em seguida, foram adicionadas às amostras testes. Concentrações decrescentes das citocinas foram diluídas na solução de bloqueio e utilizadas para a confecção de uma curva padrão. A placa foi coberta e mantida por $18-24$ horas a $4^{\circ} \mathrm{C}$.

No terceiro dia, a placa foi lavada por 3 vezes e, posteriormente, adicionados os anticorpos biotinizados específicos anti-TNF- $\alpha$, anti-IL-1 $\beta$, anti-KC ou anti-IL-6. Após 1 hora de incubação à temperatura ambiente, a placa foi lavada e o conjugado avidina-peroxidase, na diluição de 1:5000, adicionado a cada poço por 20 minutos. A 
placa foi lavada e incubada com $50 \mu$ do substrato dihidrocloro 1,2-fenilenodiamina (ortofenileno diamina, OPD, Sigma-Aldrich) por 15 a 20 minutos em temperatura ambiente. A reação foi interrompida com $50 \mu \mathrm{L}$ de $\mathrm{H}_{2} \mathrm{SO}_{4}(2 \mathrm{~N})$ e a densidade óptica medida a $450 \mathrm{~nm}$ em espectrofotômetro (Spectra Max-250, Molecular Devices). Os resultados foram expressos em $\mathrm{pg} / \mathrm{mg}$ de tecido ou $\mathrm{pg} / \mathrm{mL}$ de células em relação à curva padrão obtida.

\subsection{Geração de animais quimeras de medula óssea}

\subsubsection{Isolamento de células tronco}

Células tronco provenientes da medula óssea de animais doadores foram isoladas através da técnica de flushing da medula. Esses doadores consistiram em animais WT, $\mathrm{NOD}^{-/-}$, NOD2 $2^{-/-}$e animais GFP-totais, os quais, são animais transgênicos que expressam a proteína fluorescente verde (GFP-green fluorescense protein) sob o controle do gene promotor da ubiquitina humana $\mathrm{C}$, o que favorece a expressão de tal proteína em todos os tecidos do animal, incluindo tecido hematopoiético. Brevemente, os fêmures e as tíbias dos animais foram limpos do tecido muscular e periósteo, através de raspagem com lâmina de bisturi e, após remoção das epífises, a medula óssea foi ejetada do interior da diáfise através de um flushing com uma seringa de $5 \mathrm{~mL}$ e agulha $26 \mathrm{G}$ contendo meio de cultura DMEM. As células foram então centrifugadas a 1200rpm por 10 minutos, ressuspensas em PBS, contadas em azul de trypan e diluídas a uma concentração de $2,5 \times 10^{7} / \mathrm{mL}$ $\left(4 \times 10^{6} / 200 \mu \mathrm{L}\right)$ para inóculo intravenoso. 


\subsubsection{Construção dos camundongos quimeras}

Camundongos WT, NOD1 $1^{-/-}$e NOD2 $2^{-/-}$, com aproximadamente 8 a 9 semanas, foram considerados receptores e expostos a uma irradiação de 9 Grays (Gy) por aproximadamente 400 segundos, proveniente de uma fonte de raio X (Mark I (model 25) fonte Cs 137). No dia seguinte à irradiação, antes de serem repovoados com $4 \times 10^{6}$ células tronco provenientes da medula óssea dos camundongos doadores, por injeção intravenosa no plexo orbital, os animais foram divididos nos seguintes grupos: 1) animais WT, $\mathrm{NOD}^{-/-}$e NOD2 ${ }^{-/-}$que receberam células da medula óssea de animais WT, 2) animais $\mathrm{NOD}^{-/-}$que receberam células da medula óssea de animais $\mathrm{NOD}^{-{ }^{--}} \mathrm{e}$ 3) animais $\mathrm{NOD}^{-/-}$que receberam células da medula óssea de animais NOD2 $\left.{ }^{-{ }^{-}}, 4\right)$ animais WT, $\mathrm{NOD}^{-/-}$e NOD2 $2^{-/-}$que receberam células da medula óssea de animais $\mathrm{GFP}^{+}$. Além desses, um grupo controle foi criado para comprovar o caráter letal da irradiação, no qual camundongos foram irradiados e não transferidos com medula óssea.

Durante os 15 dias que se seguiram à irradiação os animais receberam tratamento com o antibiótico cloridrato de ciprofloxacino diluído na água a uma concentração de $10 \mathrm{mg} / \mathrm{mL}$. O período estabelecido para a chamada 'pega medular' foi cerca de 2 meses após a irradiação e transferência da nova medula óssea. Após esse período, os animais foram submetidos à cirurgia para indução de neuropatia periférica.

De modo a confirmar a adequada transferência das células hematopoiéticas, o grupo de animais irradiados e que receberam células de animais GFP-totais, foram sacrificados 2 meses após a reconstituição e, seu baço, linfonodos e sangue total, foram avaliados quanto a presença de células $\mathrm{GFP}^{+}$por citometria de fluxo. 
As amostras foram processadas de modo que, nas amostras de sangue e baço, células vermelhas foram eliminadas utilizando tampão de lise adequado (150 mMNH4Cl; 1,25 mM- EDTA; 50 mM NaCO3; pH=7,2). A frequência de células GFP ${ }^{+}$ foram determinadas em citômetro de fluxo (FACS-Verse; BD Bioscience). A porcentagem de células $\mathrm{GFP}^{+}$serviram como indicativo da eficiência da transferência de células hematopoiéticas.

\subsection{Análise estatística}

Os resultados foram expressos como a média \pm erro padrão da média (E.P.M.) por grupo de cinco a oito animais. Conforme indicado, a análise dos resultados foi feita pelo teste de análise de variância (ANOVA) de dois fatores (grupo e tempo) ou de um fator (grupo). As comparações post-hoc foram realizadas com o teste de Tukey. Para se comparar dois grupos de variáveis não-pareadas, utilizou-se o teste t de student. As diferenças foram consideradas significativas para valores de $P<0,05$. Para a realização das análises estatísticas citadas e confecção gráfica foi utilizado um programa estatístico específico computadorizado (GraphPad Prism 5 Software, EUA, 2007). 
Resultados 


\section{Resultados}

\subsection{Expressão de NOD1 e NOD2 na medula espinal}

Primeiramente, foi determinado o perfil de expressão dos receptores NOD1 e NOD2 na medula espinal, ao longo do desenvolvimento da neuropatia periférica. Por análise de RT-qPCR, foi observado um aumento significativo na expressão do RNAm de NOD1 nos dias 7 e 10 após realização da cirurgia, quando comparados aos animais falsamente operados Sham (Fig. 1A). Já a expressão do RNAm de NOD2 demonstrou níveis constitutíveis que não se alteram após desenvolvimento da neuropatia periférica (Fig. 1B). Corroborando o resultado obtido para NOD1, foi observado por Western Blotting que a expressão de NOD1 é induzida após a cirurgia de SNI (Fig. 2). Por essa mesma técnica, não foi observada expressão de NOD2 na medula espinal.
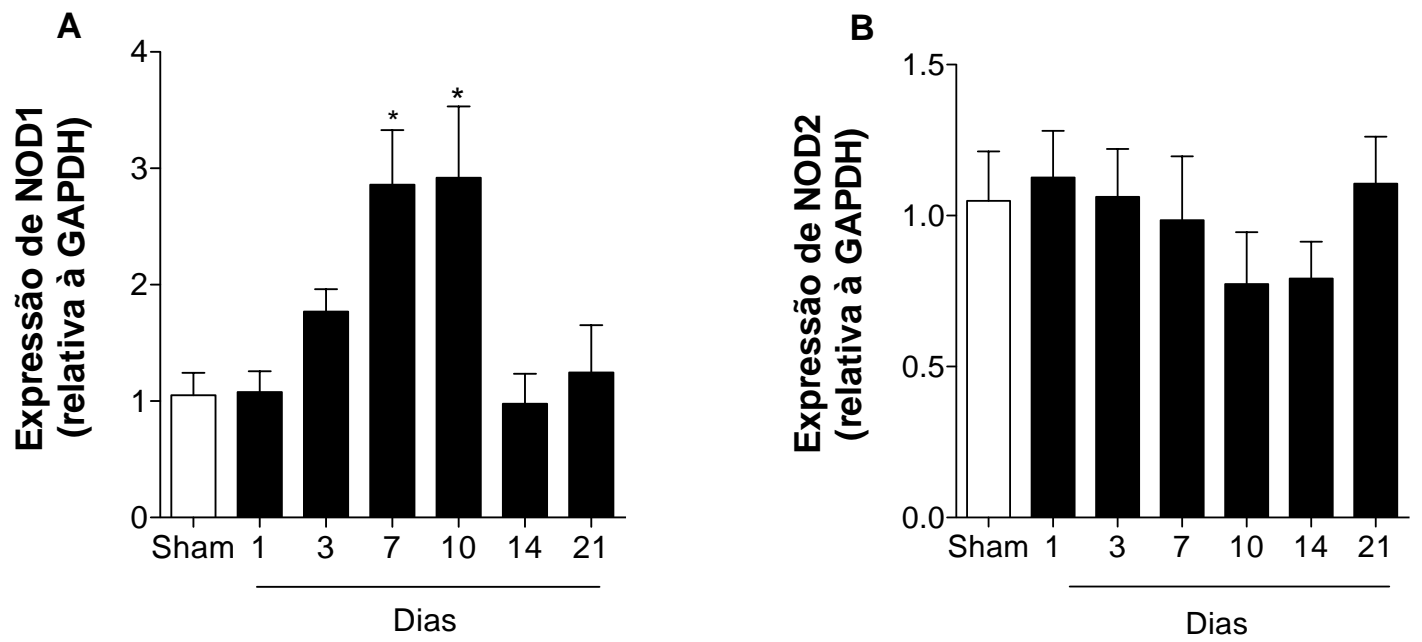

Figura 1. Expressão de NOD1 e NOD2 na medula espinal. Análise por RT-qPCR da expressão de RNAm de NOD1 (A) e NOD2 (B) nas medulas espinais de camundongos WT após a indução de neuropatia periférica (SNI) e de animais falsamente operados (Sham). Nos dias 1, 3, 7, 10, 14 e 21 após a realização da cirurgia, as amostras foram coletadas. A expressão dos genes foi normalizada em relação à expressão da GAPDH. Os dados foram expressos como média \pm E.P.M. de 5-8 animais por grupo ( ${ }^{*}<<0,05$ quando comparada ao grupo controle Sham). 

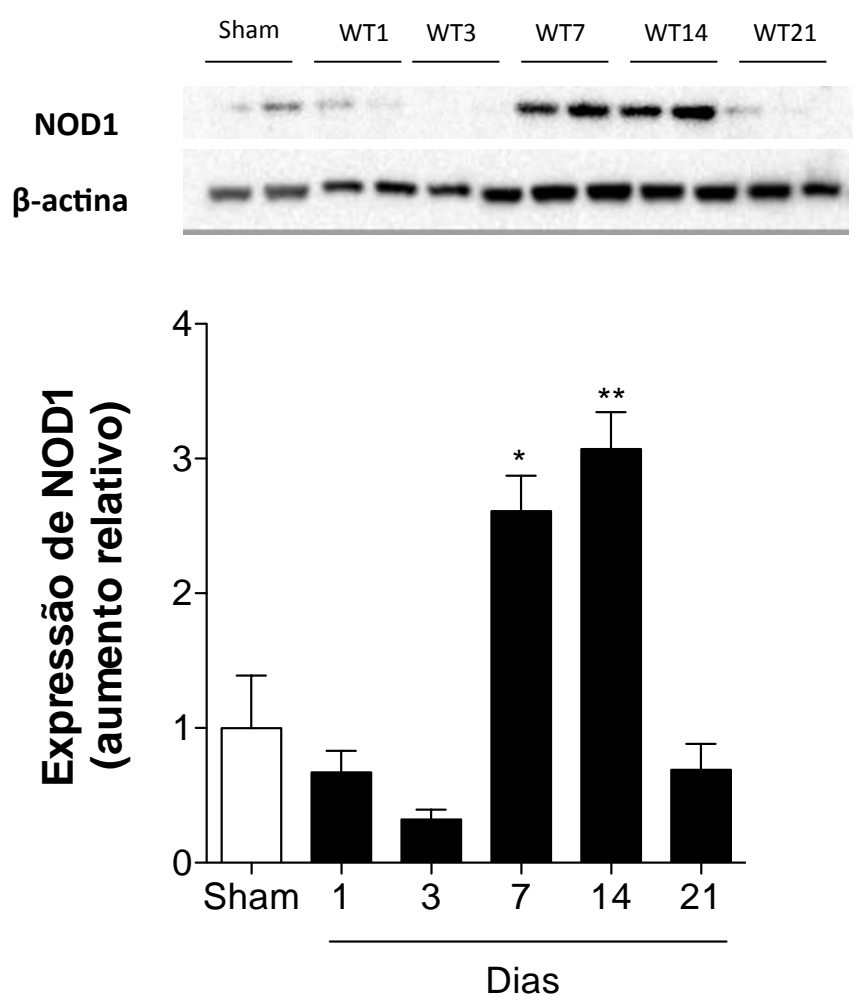

Figura 2. Expressão de NOD1 medula espinal. Análise por Western blotting da expressão dos receptor NOD1 nas medulas espinais de camundongos WT após a indução de neuropatia periférica (SNI) e de animais falsamente operados (Sham). Nos dias 1, 3, 7, 14 e 21 após a realização da cirurgia, as amostras foram coletadas. O peso molecular de NOD1 e da $\beta$-actina são 95 e $42 \mathrm{kDa}$, respectivamente. A análise da intensidade ótica das bandas foi realizada com auxílio do programa Image Lab Software Bio Rad. Os dados foram expressos como média \pm E.P.M. de 4 animais por grupo $\left({ }^{*} \mathrm{p}<0,05 ;{ }^{* *} \mathrm{p}<0,01\right.$ quando comparada ao grupo controle Sham).

\subsection{NOD1 é expresso nos neurônios da medula espinal após indução de neuropatia periférica}

Como demonstrado acima, NOD1 é expresso na medula espinal após a indução de neuropatia periférica. Para identificar o tipo de célula que expressa esse receptor, medulas de animais $\mathrm{WT}$ e $\mathrm{NOD}^{-/-}$foram coletadas no pico de expressão de NOD1, ou seja, no décimo dia, para análise através da técnica de imunofluorêscencia por dupla marcação, utilizando uma marcação específica de NOD1 e outra específica de núcleos neuronais $(\mathrm{NeuN})$. 
A análise por microscopia confocal revelou que após lesão nervosa periférica, uma ativação da NOD1 (marcação vermelha) foi observada no lado ipsilateral dos animais WT (WT-SNI), diferentemente dos animais Sham (WT-Sham), onde apenas uma discreta marcação de NOD1 foi percebida (Fig. 3). Já nos animais NOD1 ${ }^{-1-}$ não foi observada expressão de NOD1, confirmando a especificidade do anticorpo testado (Fig. 3). Com relação ao NeuN (marcação verde), todos os grupos testados apresentaram marcação neuronal. Além disso, podemos verificar que nas células positivas para NOD1 houve marcação neuronal sugerindo que na medula espinal, após indução de neuropatia periférica, os receptores NOD1 estão expressos em neurônios (Fig. 4 ). 


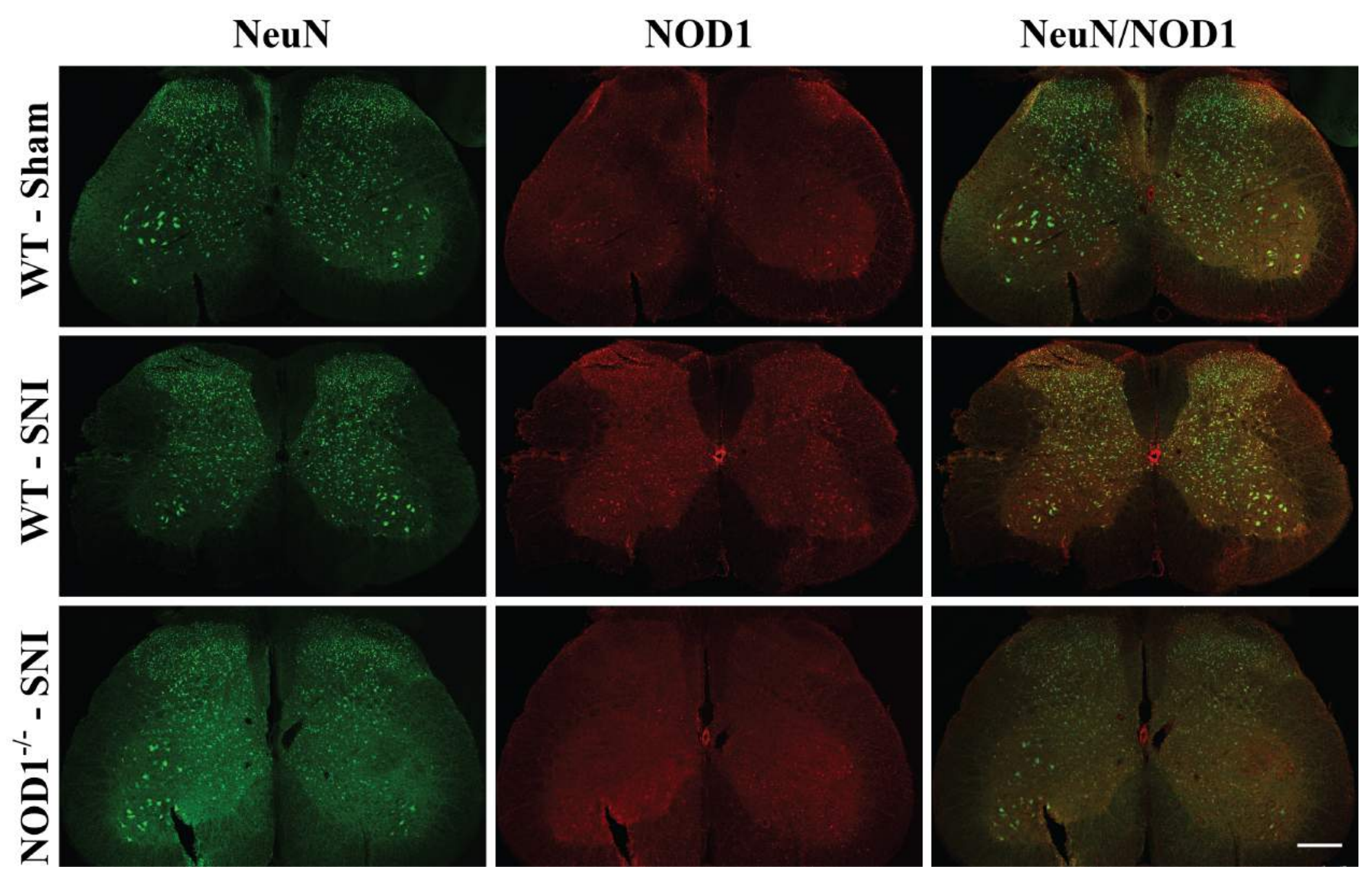

Figura 3. Expressão de NOD1 nos neurônios da medula espinal após lesão nervosa periférica. Camundongos WT e NOD1 ${ }^{-/}$foram submetidos a indução de SNI ou falsamente operados (Sham). No dia 10 pós-cirurgia, as medulas espinais foram coletadas para análise através da técnica de imunofluorêscencia por dupla marcação. As imagens demonstram imunoreatividade para neurônios, através do anticorpo anti-NeuN (verde, coluna da esquerda), para NOD1, através do anticorpo anti-NOD1(vermelho, coluna do meio) e colocalização dessas duas marcações (amarelo, coluna à direita). A análise foi realizada por microscopia confocal. Barra de escala de 250 um. 


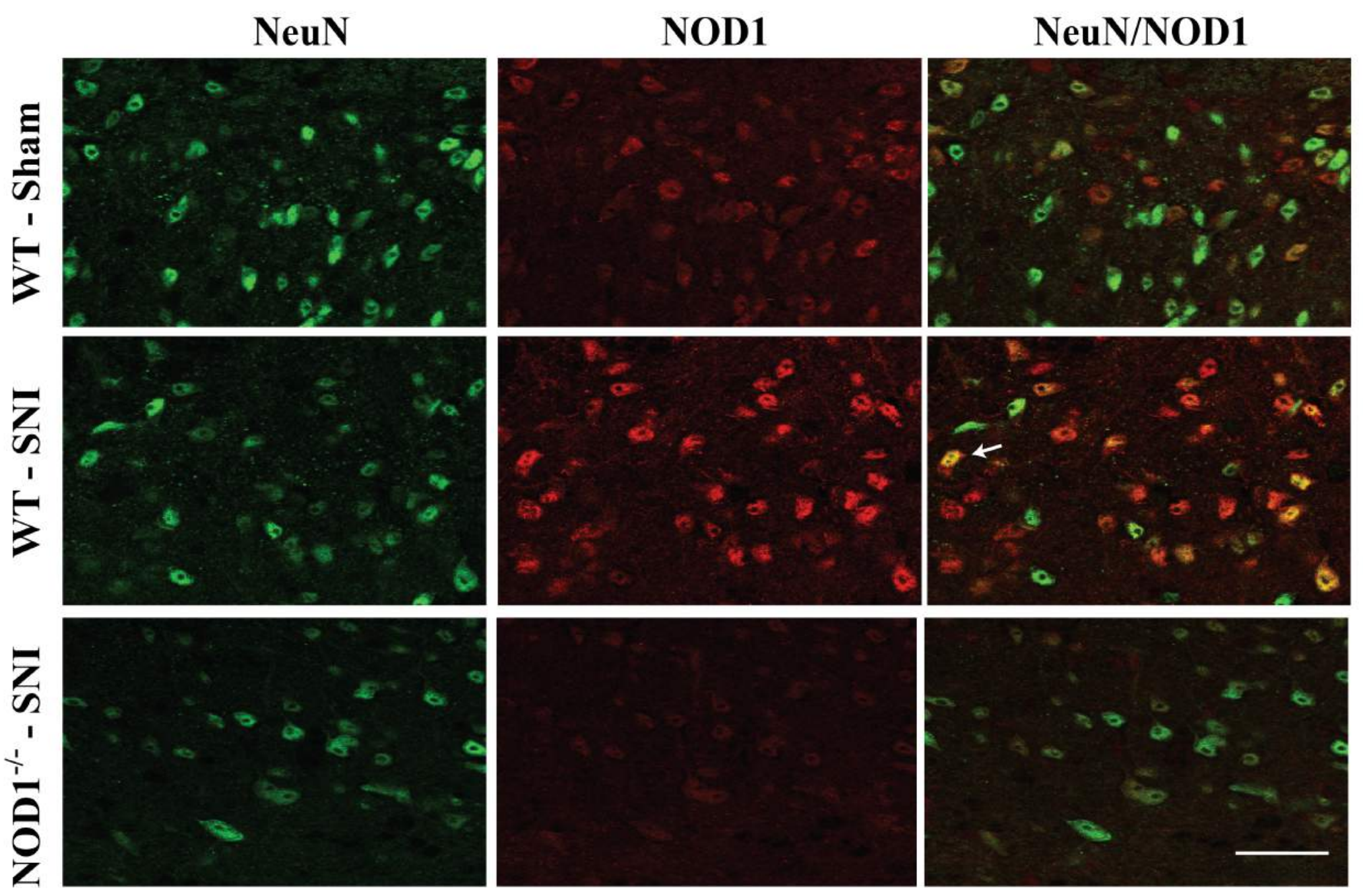

Figura 4. Expressão de NOD1 nos neurônios da medula espinal após lesão nervosa periférica. As imagens demonstram uma ampliação de uma região do corno dorsal da medula espinal, apresentando imunoreatividade para neurônios, através do anticorpo anti-NeuN (verde, coluna da esquerda), para NOD1, através do anticorpo antiNOD1(vermelho, coluna do meio) e colocalização dessas duas marcações (coluna à direita). A seta indica dupla marcação (amarelo). A análise foi realizada por microscopia confocal. Barra de escala de $25 \mu \mathrm{m}$. 


\subsection{Animais deficientes para NOD1 e NOD2 respondem normalmente a diferentes estímulos nocivos}

Antes de se iniciar a investigação do papel dos receptores NOD1 e NOD2 na indução de dor crônica neuropática e inflamatória, foram realizados experimentos para avaliar a resposta de animais $\mathrm{WT}, \mathrm{NOD}^{-/-}$e $\mathrm{NOD}^{-/-}$frente a diferentes estímulos nociceptivos.

Primeiramente, avaliamos o limiar mecânico dos animais frente a diferentes filamentos de von Frey. Dessa maneira, foi observado que tanto os animais WT como também $\mathrm{NOD}^{-/-}$e NOD2 $2^{-/}$apresentaram limiar mecânico de retirada da pata posterior direita semelhantes (Fig.5). Em seguida, investigamos a participação desses receptores na nocicepção térmica pelo teste da Placa Quente. Como resultado, os animais $\mathrm{NOD}^{-/-}$e $\mathrm{NOD}^{-/-}$não apresentaram diferença significativa no tempo de latência quando comparados ao grupo dos animais WT (Fig. 6).

O terceiro modelo testado foi a nocicepção química induzida pela administração subplantar de formalina. De fato, não foi observada diferença significativa no tempo de lambida da pata entre os animais WT, NOD1 ${ }^{-/-}$e NOD2 $2^{-/-}$ (Fig. 7). Assim sendo, os resultados sugerem que os animais $\mathrm{NOD}^{-/-}$e NOD2 $2^{-/-}$ respondem normalmente a diferentes estímulos nociceptivos, da mesma maneira que os animais WT. 


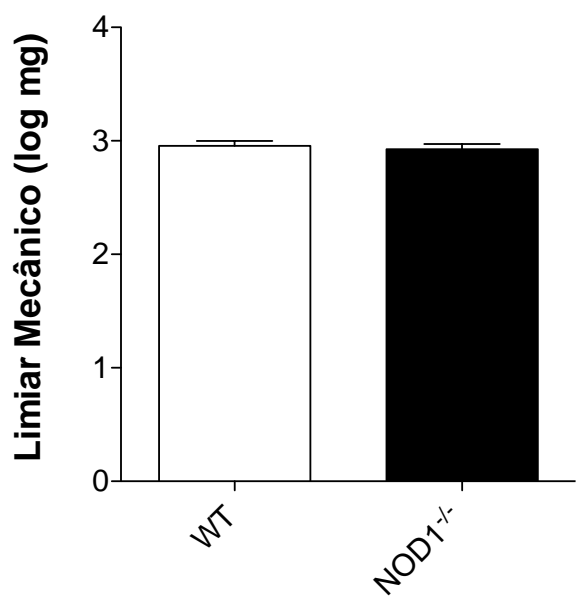

B

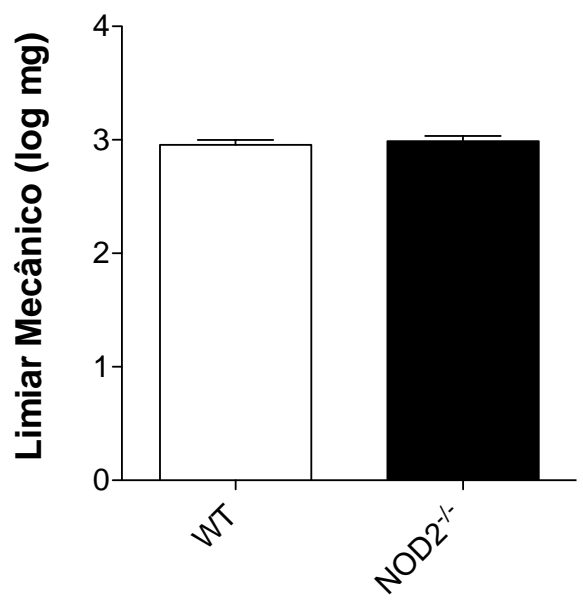

Figura 5. Avaliação da nocicepção mecânica em animais NOD1 ${ }^{-/-}$e NOD2 ${ }^{-/-}$. Camundongos machos WT, $\mathrm{NOD}^{-/-}$(A) e NOD2 ${ }^{-/-}$(B) foram avaliados quanto à estimulação mecânica, através dos filamentos de von Frey. O filamento de menor força capaz de induzir resposta foi determinado como sendo o limiar mecânico de retirada. Os dados foram expressos como média \pm E.P.M. de 6-8 animais por grupo.

A

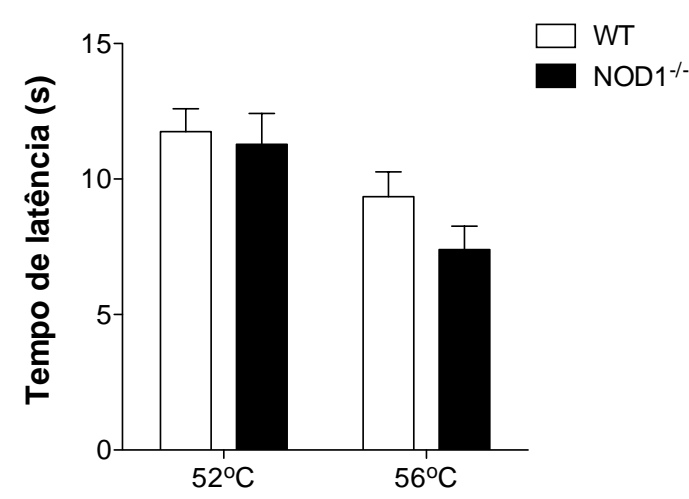

B

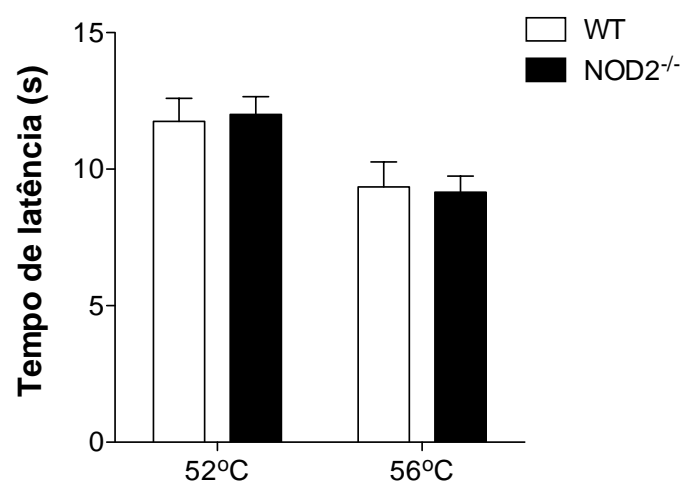

Figura 6. Avaliação da nocicepção térmica em animais NOD1 ${ }^{-/}$e NOD2 ${ }^{-/}$. Camundongos WT, $\mathrm{NOD}^{-/-}$e $\mathrm{NOD}^{-/-}$foram colocados individualmente na placa quente aquecida a diferentes temperaturas $\left(52^{\circ} \mathrm{C}\right.$ e $\left.56^{\circ} \mathrm{C}\right)$ onde uma resposta característica, na qual o animal troca rapidamente o apoio dos pés, levanta ou lambe uma das patas é avaliado. Os resultados foram expressos como a latência para o aparecimento desta resposta em segundos para NOD1 (A) e NOD2 (B). Os dados foram expressos como média \pm E.P.M. de 6-8 animais por grupo. 
A
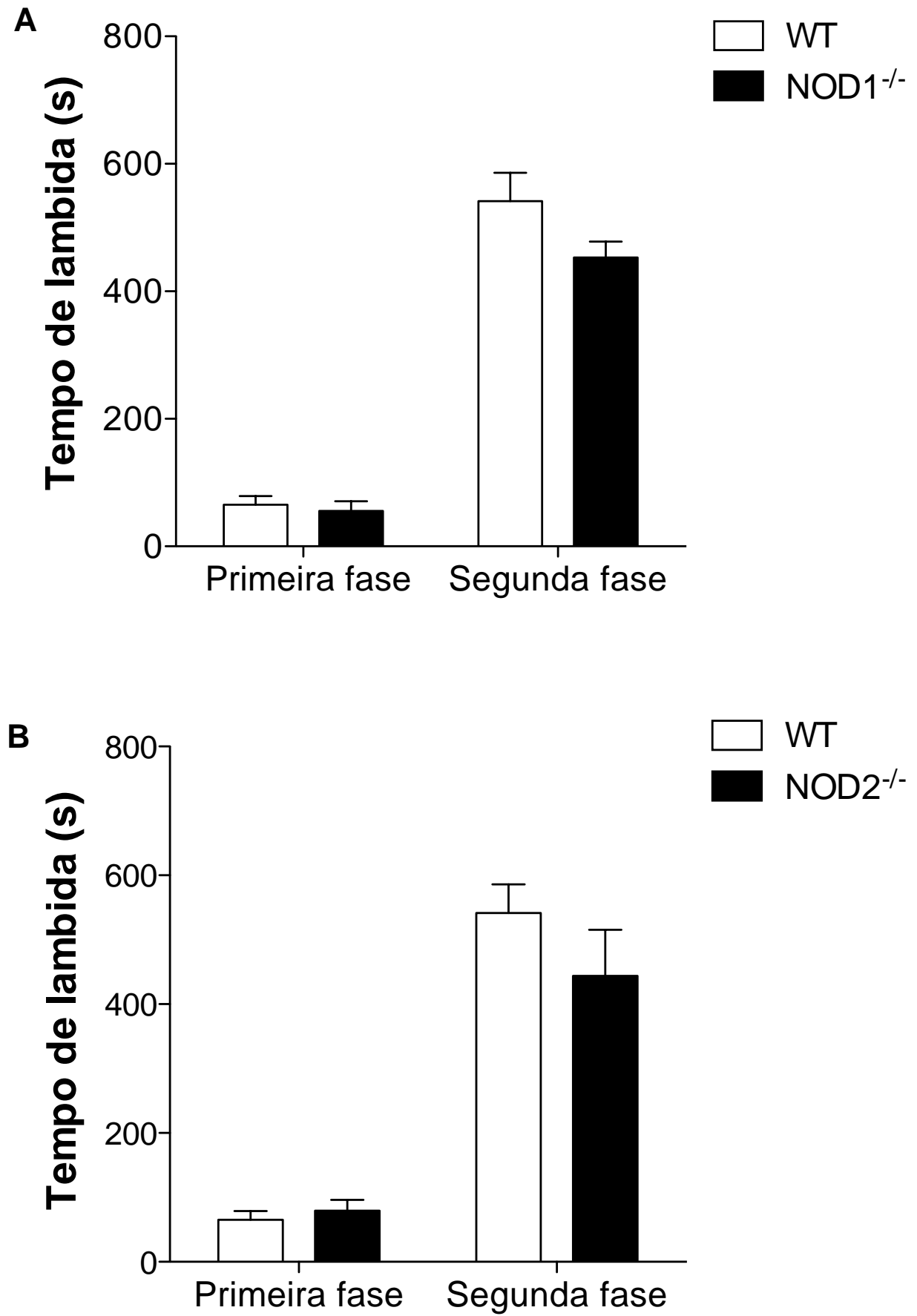

Figura 7. Avaliação da nocicepção química em animais NOD1 ${ }^{-/}$e NOD2 ${ }^{-/}$. Camundongos WT, $\mathrm{NOD}^{-/}$e $\mathrm{NOD}^{-/-}$receberam administração subplantar de uma solução de formalina $1 \%$ na pata traseira direita. O tempo de lambida foi então cronometrado a cada 5 minutos durante um período total de 50 minutos. Os resultados foram expressos como tempo de lambida (s) em relação a $1^{\text {a }}$ fase $(0-10$ min) e $2^{\text {a }}$ fase $(10-50 \mathrm{~min})$, para NOD1 (A) e NOD2 (B). Os dados foram expressos como média \pm E.P.M de 6-8 animais por grupo. 


\subsection{NOD1 e NOD2 contribuem para gênese da dor neuropática}

Em seguida, avaliou-se o desenvolvimento da dor neuropática em animais $\mathrm{NOD}^{-/-}$e NOD $2^{-/-}$machos e fêmeas. Primeiramente, foi realizada a medida basal dos animais, sendo que em seguida, animais selvagens ou deficientes foram submetidos à cirurgia para indução de neuropatia periférica pela lesão dos nervos peroneal e tibial (SNI). Três dias após a realização da cirurgia foram iniciadas as medidas do limiar nociceptivo, avaliadas durante 21 dias, através do teste mecânico de filamentos de von Frey.

Após a indução de neuropatia periférica nos machos, os animais WT, NOD1 $1^{-/-}$ e $\mathrm{NOD}^{-/-}$apresentaram claramente uma hipersensibilidade mecânica quando comparados aos animais falsamente operados WT-Sham, NOD $1^{-/-}$-Sham e NOD2 ${ }^{-/-}$Sham, respectivamente. Foi observado no grupo WT que o limiar de retirada da pata começou a diminuir no terceiro dia após a lesão do nervo, e atingiu o limiar mínimo no décimo quarto dia $(1,69 \pm 0,13 \log \mathrm{mg})$, em comparação com o limiar basal antes da cirurgia $(3,00 \pm 0.00 \log \mathrm{mg})$ (Fig. 8). Já os animais NOD1 $1^{-/}$e NOD2 ${ }^{-/-}$atingiram o limiar mínimo também no décimo quarto dia, no entanto, reduziram apenas para 2,09 $\pm 0,30 \log \mathrm{mg}$ para $\mathrm{NOD}^{-/-}($Fig. $8 \mathrm{~A})$ e para 2,18 $\pm 0,34 \log$ mg para NOD2 $2^{-/}$ (Fig. 8B), em comparação com o seus respectivos limiares basais $(3,00 \pm 0,00 \log \mathrm{mg}$ para $\mathrm{NOD}^{-{ }^{-}}$e $3,02 \pm 0,05 \mathrm{log} \mathrm{mg}$ para NOD2 $2^{-/}$). Portanto, foi observado que os machos $\mathrm{NOD}^{-/-}$e NOD2 ${ }^{-/-}$apresentaram redução significativa da hipersensibilidade mecânica em comparação aos machos WT, do quinto ao vigésimo primeiro dia após a cirurgia SNI.

Com relação às fêmeas, foi observado um comportamento semelhante ao apresentado pelos machos. No grupo WT, o limiar de retirada da pata começou a diminuir no terceiro dia após a lesão do nervo, e atingiu o limiar mínimo no décimo 
dia $(1,58 \pm 0,20 \log \mathrm{mg})$, em comparação com o limiar basal antes da cirurgia $(2,77 \pm$ $0.00 \log \mathrm{mg}$ ) (Fig. 9). Já o limiar de retirada da pata dos animais NOD1 ${ }^{-/}$, no entanto, reduziu apenas para 2,06 $\pm 0,18 \log \mathrm{mg}$ (Fig. 9A), e $\mathrm{NOD}^{-{ }^{--}}$para 2,08 $\pm 0,18 \log \mathrm{mg}$ (Fig. 9B), em comparação com o seus respectivos limiares basais $(2,80 \pm 0,07 \log \mathrm{mg}$ para $\mathrm{NOD}^{-{ }_{-}}$e $2,77 \pm 0,00 \log \mathrm{mg}$ para NOD2 $2^{-{ }_{-}}$).

Assim, foi observado que as fêmeas deficientes apresentaram redução significativa da hipersensibilidade mecânica em comparação às fêmeas selvagens, do quinto ao vigésimo primeiro dia para $\mathrm{NOD}^{-/-}$e NOD2 ${ }^{-/-}$. Este mesmo comportamento não foi observado nos animais falsamente operados WT-Sham, NOD1 ${ }^{-/-}$-Sham e

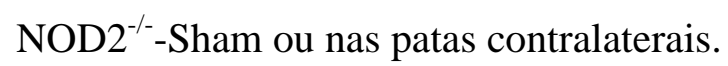

Diante do perfil semelhante apresentado por camundongos machos e fêmeas, uma vez que ambos os sexos dos animais deficientes reduziram a hipersensibilidade pós-neuropatia, quando comparado aos animais selvagens, a partir de agora, será padronizado que todos os experimentos seguintes serão realizados em camundongos machos. Além disso, devido a semelhança de perfil observado nos animais deficientes falsamente operados (NOD1 $1^{-/-}$-Sham e NOD2 $2^{-/-}$-Sham) com os selvagens (WT-Sham), para os experimentos seguintes foi optado por manter somente um grupo de animais falsamente operados, o WT-Sham, que seria representativo dos demais grupos também. 
A
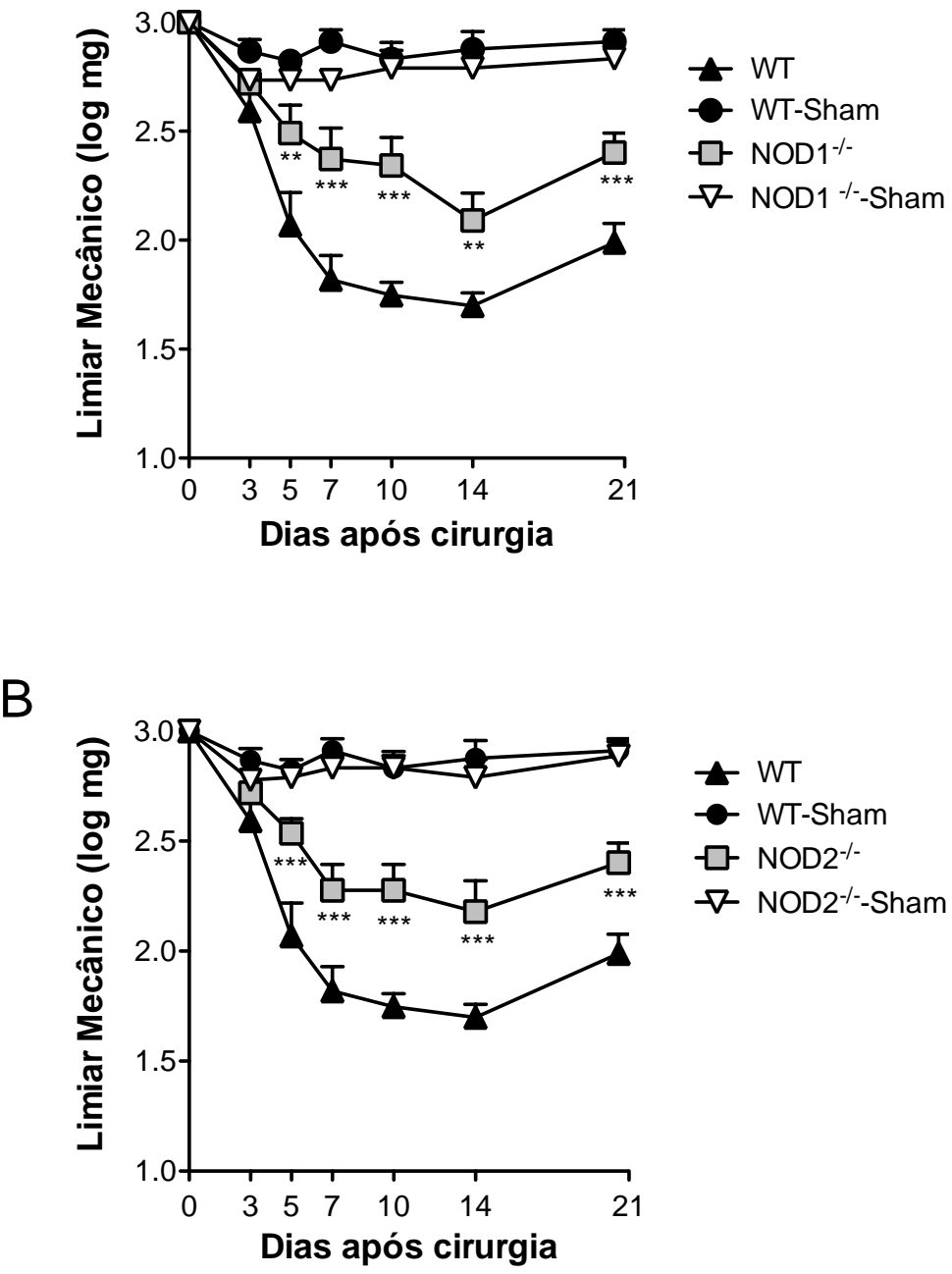

Figura 8. Avaliação da nocicepção mecânica em camundongos machos submetidos à neuropatia periférica. Camundongos machos WT, NOD1 ${ }^{-/-}$(A) e NOD2 ${ }^{-/-}$(B) foram submetidos a indução de SNI ou falsamente operados (Sham) e, após, avaliados quanto à estimulação mecânica, através dos filamentos de von Frey, durante um período de 21 dias. Os dados foram expressos como média \pm E.P.M. de 8 animais por grupo. $\left({ }^{*} \mathrm{p}<0,05 ;{ }^{* *} \mathrm{p}<0,01 ; * * * \mathrm{p}<0,001\right.$ quando comparada ao grupo WT). 
A

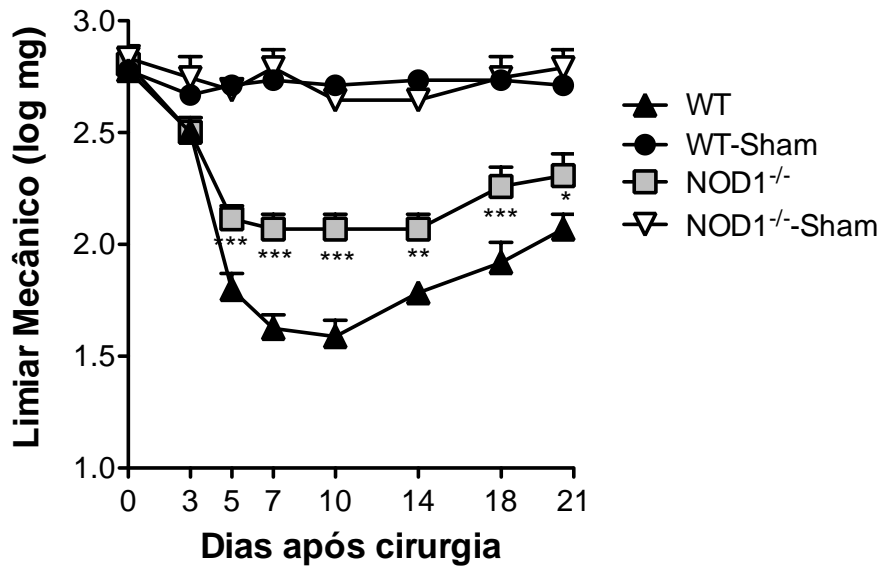

B

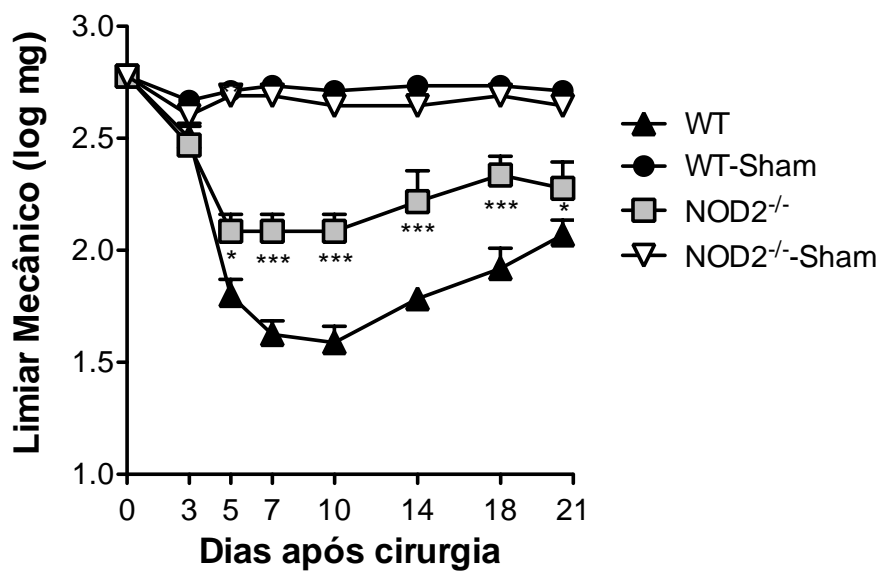

Figura 9. Avaliação da nocicepção mecânica em camundongos fêmeas submetidos à neuropatia periférica. Camundongos fêmeas WT, $\mathrm{NOD}^{-1-}$ (A) e NOD2 ${ }^{-1-}$ (B) foram submetidos a indução de SNI ou falsamente operados (Sham) e, após, avaliados quanto à estimulação mecânica, através dos filamentos de von Frey, durante um período de 21 dias. Os dados foram expressos como média \pm E.P.M. de 8 animais por grupo. $\left({ }^{*} \mathrm{p}<0,05 ;{ }^{* *} \mathrm{p}<0,01 ; * * * \mathrm{p}<0,001\right.$ quando comparada ao grupo WT).

\subsection{NOD1 e NOD2 não estão envolvidos na indução da dor inflamatória}

O próximo passo do trabalho foi avaliar se os receptores NOD1 e NOD2 também participam do processo de indução e manutenção da dor crônica inflamatória. Com esse intuito, primeiramente foi realizada a medida basal dos animais, sendo que em seguida, animais selvagens e deficientes foram submetidos à indução de 
hipersensibilidade inflamatória pela administração intraplantar de CFA na pata posterior direita dos animais. Duas horas após a administração foram iniciadas as medidas de avaliação do limiar nociceptivo mecânico, através do teste de filamentos de von Frey, perdurando por 21 dias o experimento.

Foi observado que os animais selvagens e deficientes, administrados com CFA, apresentaram uma redução no limiar de retirada da pata, ou seja, um aumento da sensibilidade mecânica. No grupo WT-CFA, o limiar de retirada da pata atingiu o limiar mínimo no terceiro dia $(1,49 \pm 0,22 \log \mathrm{mg})$, em comparação com o limiar basal antes da cirurgia $(2,81 \pm 0,09$ log mg). Já o limiar mínimo de retirada da pata dos animais $\mathrm{NOD}^{-/-}$-CFA foi de $1,86 \pm 0,40 \log \mathrm{mg}$ (Fig. 10A) e 1,74 $\pm 0,13 \log \mathrm{mg}$ para NOD2 ${ }^{-/}$-CFA (Fig. 10B), em comparação com o seus respectivos limiares basais

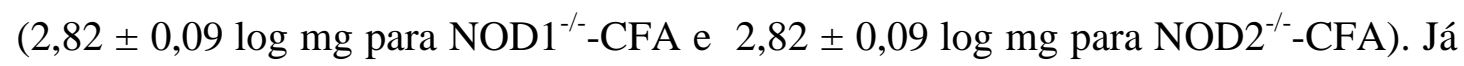
nos animais controles (WT-veículo, $\mathrm{NOD}^{-/-}$-veículo e NOD2${ }^{-/-}$-veículo), onde houve administração de salina, não foi observada redução significativa no limiar de retirada da pata, que se manteve próximo ao limiar basal durante toda a avaliação (Fig. 10). 


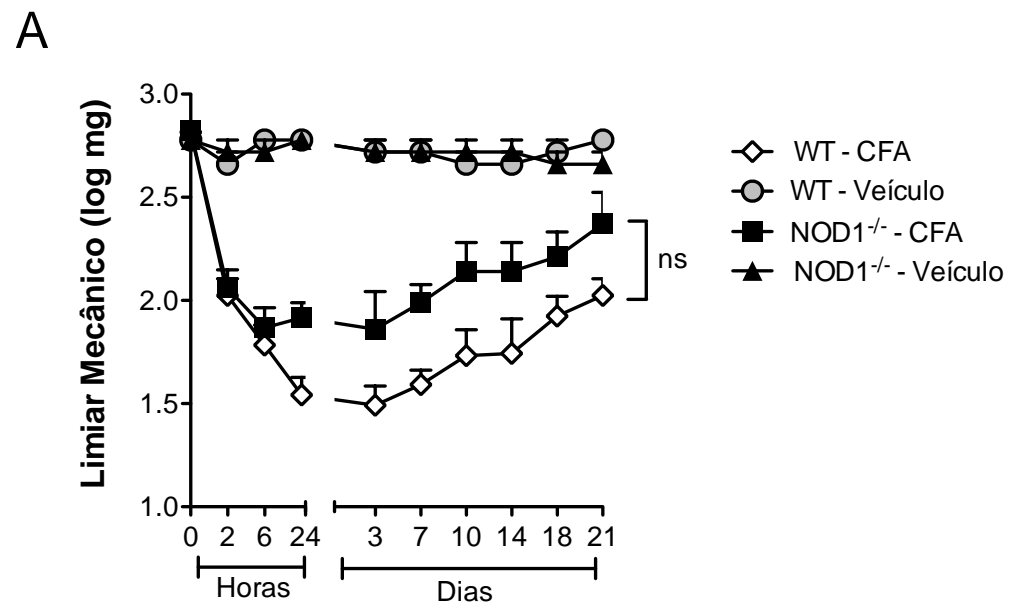

B

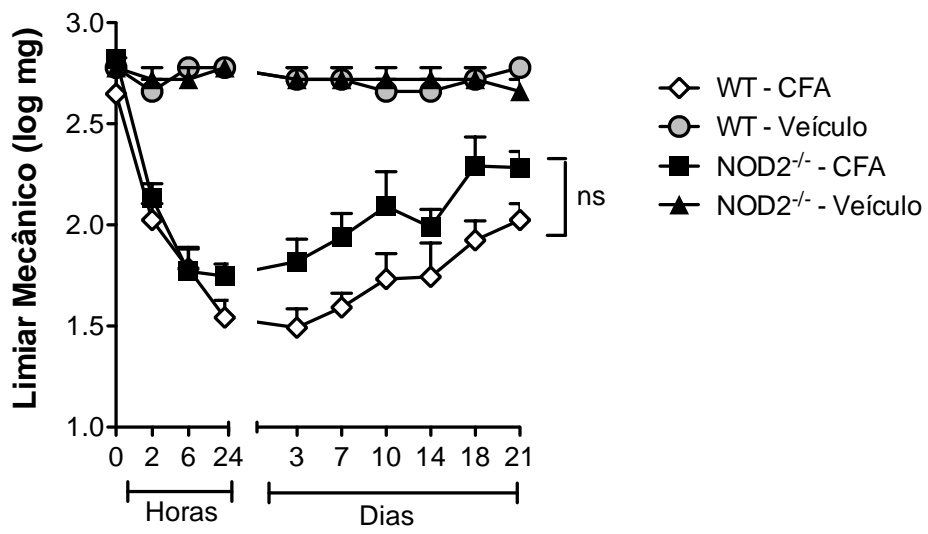

Figura 10. Avaliação da nocicepção mecânica em camundongos submetidos à inflamação periférica. Camundongos WT, NOD1 ${ }^{-/}$(A) e NOD2 $2^{-1-}$ (B) foram submetidos à administração i.pl. de CFA ou salina na pata posterior direita e, após, avaliados quanto à estimulação mecânica, através dos filamentos de von Frey, durante um período de 21 dias. Os dados foram expressos como média \pm E.P.M. de 8 animais por grupo.

\subsection{NOD1 e NOD2 contribuem para a ativação microglial após indução de neuropatia periférica}

Recentes trabalhos têm indicado que alguns PRRs, como TLR4 e TLR2, desempenham um papel crucial na ativação de células gliais na medula espinal através da indução e manutenção da dor neuropática (Kim et al., 2007; Tanga et al., 2005; Nicotra et al., 2012). Uma vez observado que os receptores NOD1 e NOD2 
contribuem para a hipersensibilidade à dor após a indução de neuropatia periférica, nosso próximo objetivo foi avaliar o possível envolvimento desses receptores na ativação de células da glia na medula espinal.

Inicialmente, foi determinado o perfil de ativação de micróglia, utilizando o IBA-1 como marcador, em animais selvagens submetidos à cirurgia de SNI. Assim, foi observado por RT-qPCR, um aumento significativo na expressão de IBA-1 no dias 3, 7 e 10 após realização da cirurgia, quando comparadas com o grupo Sham (Fig.11).

Uma vez que os animais WT, submetidos à cirurgia de indução de neuropatia, induziram um aumento significativo na ativação de micróglia, o próximo passo foi realizar o experimento nos tempos pré-estabelecidos de maior expressão com amostras de animais $\mathrm{NOD}^{-{ }^{--}}$e NOD2 $2^{-{ }^{-}}$. Dessa maneira, foi observada uma redução significativa na expressão de IBA-1 nos animais $\mathrm{NOD}^{-/-}$e $\mathrm{NOD}^{-/-}$no sétimo e décimo dia após neuropatia quando comparada ao grupo WT (Fig. 12), sugerindo que NOD1 e NOD2 contribuem para a ativação microglial no decorrer do processo neuropático.

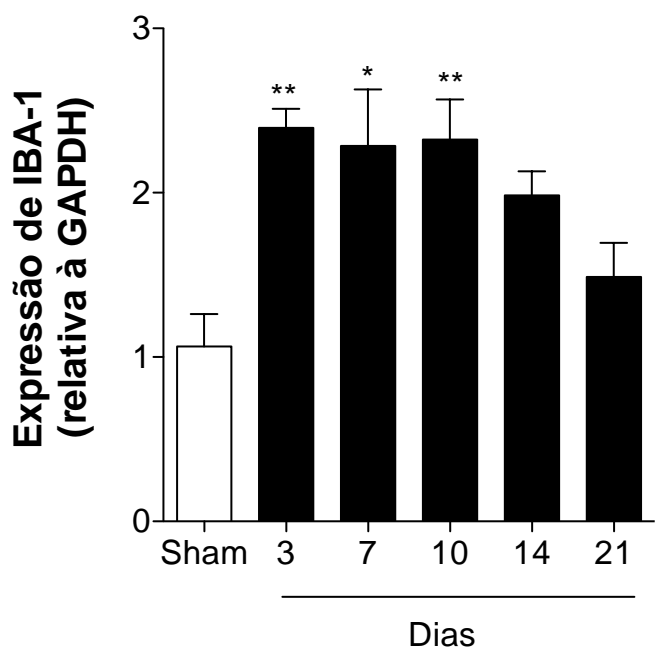

Figura 11. Perfil de ativação de micróglia em camundongos após indução de neuropatia periférica. Animais WT foram submetidos a indução de SNI ou falsamente operados (Sham). Nos dias 3,7,10,14 e 21 pós-cirurgia, as medulas espinais foram coletadas para análise da expressão de IBA-1 por RT-qPCR. Os dados foram normalizados em relação à expressão da GAPDH e expressos como média \pm E.P.M. de 8 animais por grupo ( $\mathrm{p} p<0,05 ;{ }^{*} \mathrm{p}<0,01$ quando comparada ao grupo Sham). 

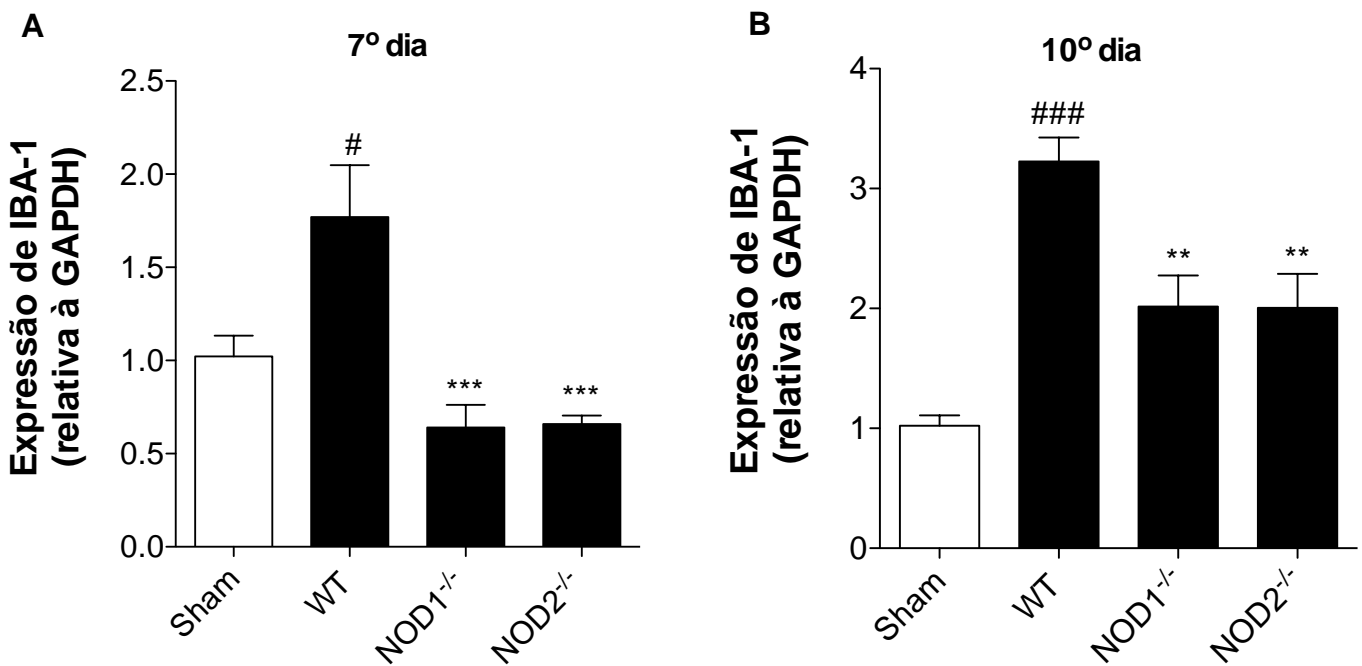

Figura 12. Avaliação da ativação de micróglia em camundongos $\mathrm{NOD}^{-/}$e NOD2 ${ }^{-/}$. Camundongos $\mathrm{WT}, \mathrm{NOD}^{-/-}$e NOD2$^{-/-}$foram submetidos a indução de SNI ou falsamente operados (Sham). Nos dias 7 e 10 pós-cirurgia, as medulas espinais foram coletadas para análise da expressão de IBA-1 por RTqPCR. Os dados foram normalizados em relação à expressão da GAPDH e expressos como média \pm E.P.M. de 8 animais por grupo $\left({ }^{\#} \mathrm{p}<0,05 ;{ }^{\# \# \#} \mathrm{p}<0,001\right.$ quando comparada ao grupo Sham $\mathrm{e}^{*} \mathrm{p}<0,05$; $* * \mathrm{p}<0,01 \mathrm{e} * * * \mathrm{p}<0,001$ quando comparada com grupo WT).

A seguir, com o intuito de confirmar se os receptores NOD1 e NOD2 realmente contribuem para a ativação microglial após indução de neuropatia periférica, determinamos através da técnica de imunofluorescência, a expressão de IBA-1 na medula espinal no décimo dia após a cirurgia, uma vez que este foi o tempo de maior ativação microglial, como demonstrado acima.

Após lesão nervosa periférica, uma forte ativação da micróglia (marcação verde) foi observada nos animais WT. É importante ressaltar que no lado ipsilateral, o número e a densidade de micróglia no corno dorsal medial e no corno ventral lateral, local onde os neurônios de primeira ordem terminam, estão significativamente aumentados (Fig.13).

Além disso, a expressão de IBA-1 revelou uma distribuição uniforme de micróglias no lado contralateral da medula espinal e no grupo Sham, caracterizada por uma morfologia típica quiescente, de pequeno corpo celular, com finas e longas 
ramificações. Entretanto, no lado ipsilateral da lesão, a micróglia do corno dorsal e ventral apresenta uma morfologia hipertrófica, com formato ameboide, indicando fortemente um estado de ativação (Fig.14).

Corroborando os resultados obtidos por RT-qPCR, foi observada uma redução significativa na expressão de IBA-1 no lado ipsilateral do corno dorsal e ventral nos animais $\mathrm{NOD}^{-{ }^{-}}$e NOD2${ }^{-/-}$quando comparada ao grupo WT (Fig. 13), apontando novamente que esses receptores contribuem para a ativação microglial após indução de neuropatia periférica. 

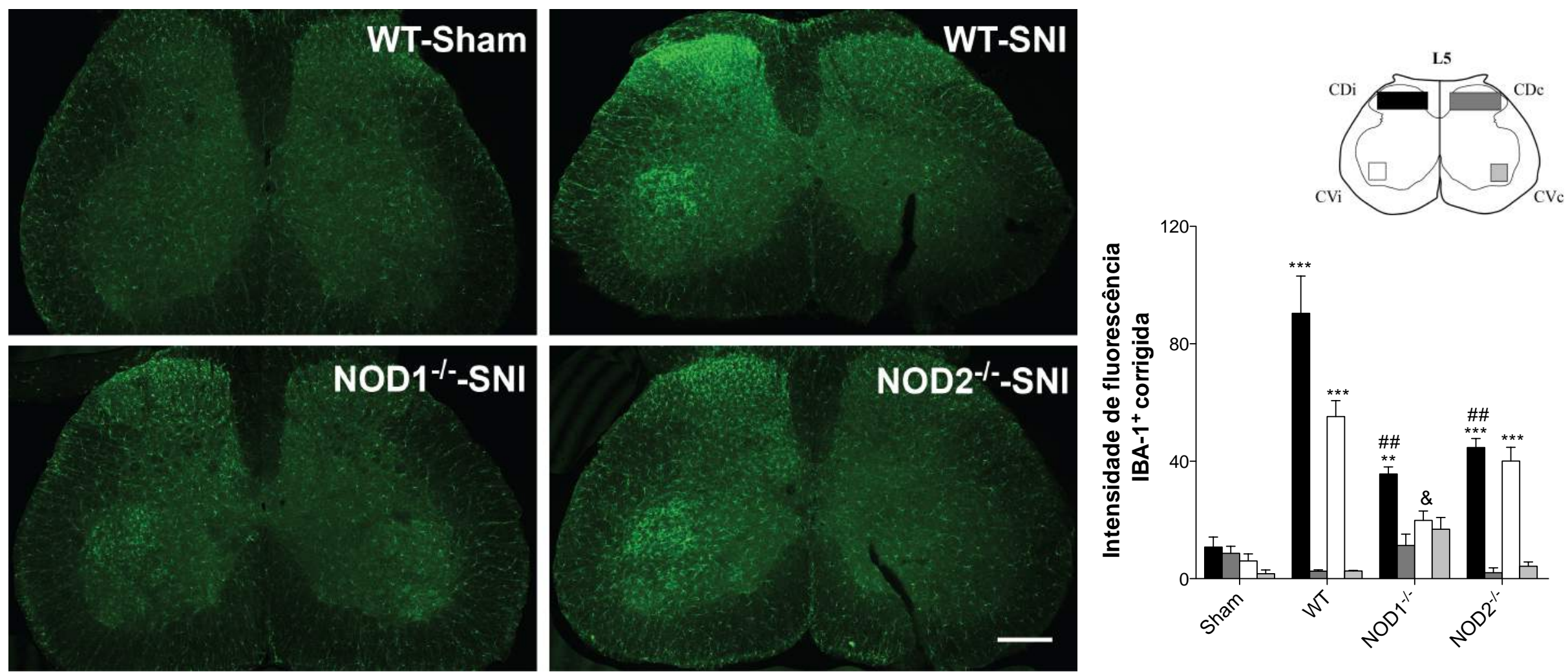

Figura 13. NOD1 e NOD2 são requeridos para ativação microglial na medula espinal após lesão nervosa periférica. Camundongos $\mathrm{WT}$, NOD $1^{-1}$ e $\mathrm{NOD} 2^{-/}$foram submetidos a indução de SNI ou falsamente operados (Sham). No dia 10 pós-cirurgia, as medulas espinais foram coletadas para análise por imunofluorêscencia. As imagens demonstram imunoreatividade para micróglia, através do anticorpo IBA-1(verde). A análise foi realizada por microscopia confocal . Barra de escala de $250 \mu \mathrm{m}$ (esquerda). A intensidade do sinal IBA-1 foi determinado como intensidade média em regiões especificas de interesse em secções da L5 e expressos como média \pm E.P.M. de 4 animais por grupo $\left(* * \mathrm{p}<0,01 \mathrm{e}{ }^{* * *} \mathrm{p}<0,001\right.$, ipsilateral vs. contralateral; ${ }^{\#} \mathrm{p}<0,01, \mathrm{NOD}^{-1-} / \mathrm{NOD} 2^{--} \mathrm{CDi}$ vs. WT CDi; ${ }^{\&} \mathrm{p}<0,05 \mathrm{NOD} 1^{-1-} \mathrm{CV}$ i vs. WT CVi) (direita). 

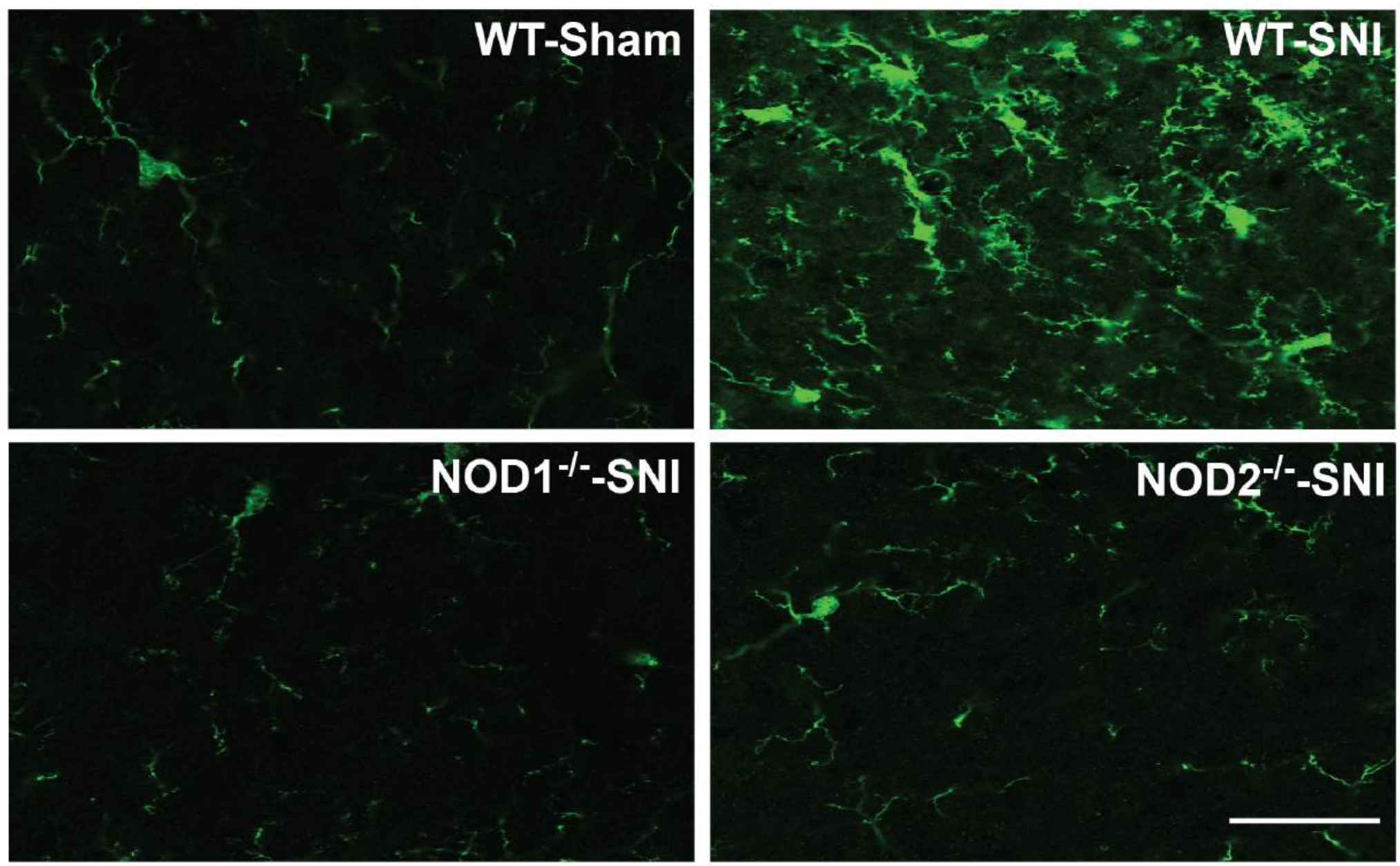

Figura 14. NOD1 e NOD2 são requeridos para ativação microglial na medula espinal após lesão nervosa periférica. As imagens demonstram uma ampliação de uma região do corno dorsal da medula espinal, apresentando imunoreatividade para micróglia, através do anticorpo IBA-1 (verde). A análise foi realizada por microscopia confocal. Barra de escala de $25 \mu \mathrm{m}$. 


\subsection{NOD1 e NOD2 contribuem para a ativação astrocitária após indução de neuropatia periférica}

Uma vez observado que os receptores NOD1 e NOD2 contribuem para a ativação microglial após a indução de neuropatia periférica, nosso próximo objetivo foi avaliar o possível envolvimento desses receptores na ativação astrocitária na medula espinal.

Como resultado, foi observado por RT-qPCR que animais NOD1 ${ }^{-/-}$e NOD2 $2^{-/-}$ apresentaram uma diminuição significativa na expressão de GFAP no sétimo dia pósneuropatia, quando comparado ao grupo WT (Fig. 15). Da mesma maneira, foi observado por imunofluorescência uma redução significativa na expressão e hipertrofia celular de GFAP no lado ipsilateral do corno dorsal dos animais NOD2 ${ }^{-/-}$ no décimo quarto dia, quando comparada ao grupo WT (Fig. 16 e 17), sugerindo assim contribuição desses receptores também no processo de ativação astrocitária após indução de neuropatia periférica.

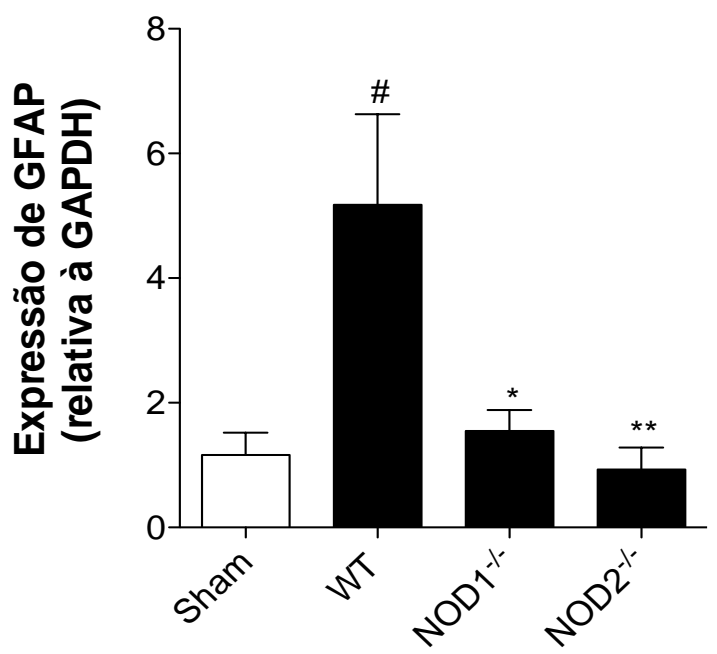

Figura 15. Avaliação da ativação de astrócitos em camundongos $\mathrm{NOD}^{-/-}$e NOD2 ${ }^{-1}$. Camundongos WT, NOD1 ${ }^{-1}$ e NOD2 ${ }^{-1-}$ foram submetidos a indução de SNI ou falsamente operados (Sham). No dia 7 pós-cirurgia, as medulas espinais foram coletadas para análise da expressão de GFAP por RT-qPCR. Os dados foram normalizados em relação à expressão da GAPDH e expressos como média \pm E.P.M. de 8 animais por grupo $\left({ }^{\#} \mathrm{p}<0,05\right.$ quando comparada ao grupo Sham $\mathrm{e}^{*} \mathrm{p}<0,05$ e ${ }^{* *} \mathrm{p}<0,01$ quando comparada com grupo WT). 

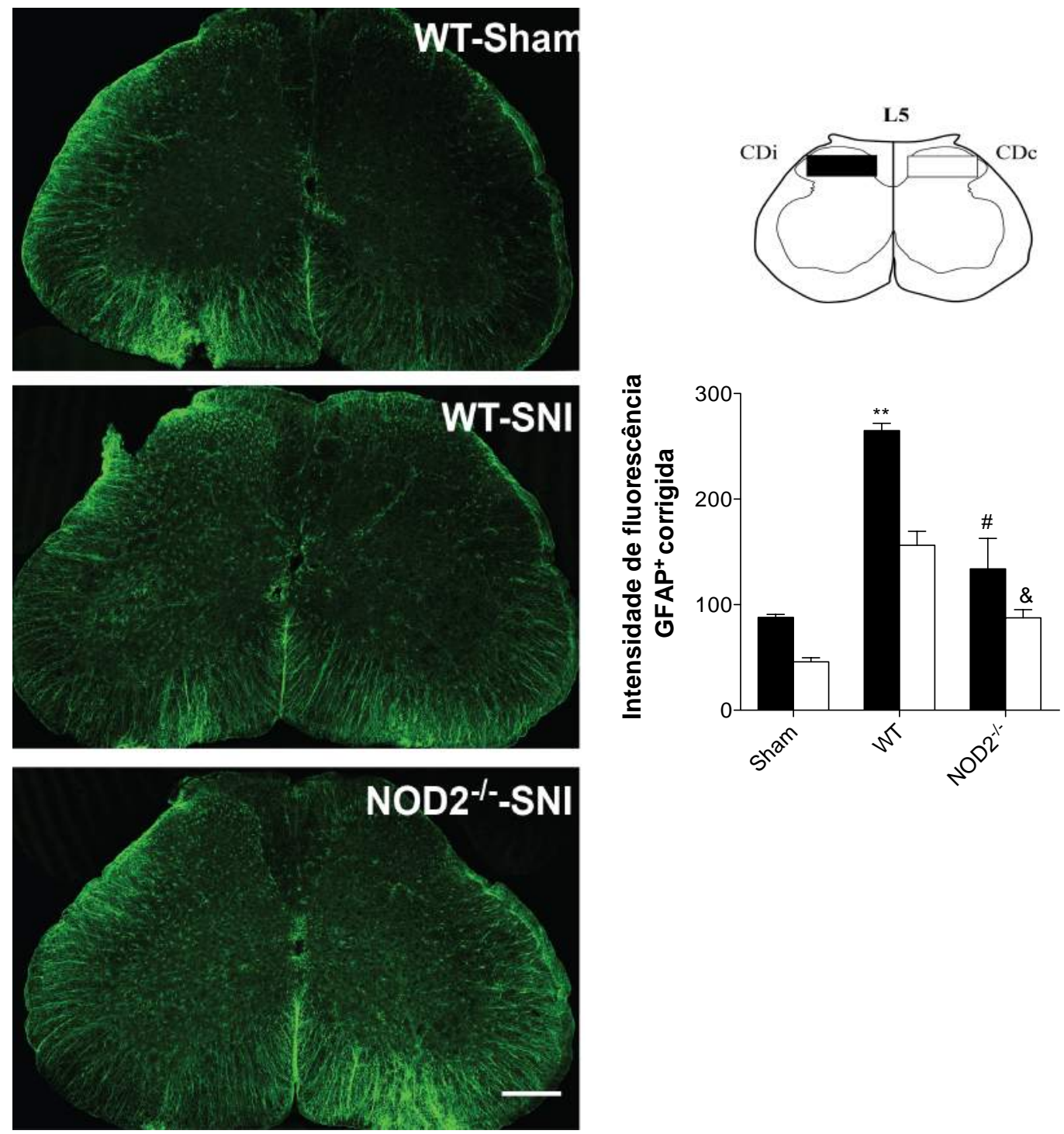

Figura 16. NOD2 é requerido para ativação astrocitária na medula espinal após lesão nervosa periférica. Camundongos WT e NOD2 $2^{-/}$foram submetidos a indução de SNI ou falsamente operados (Sham). No dia 14 pós-cirurgia, as medulas espinais foram coletadas para análise por imunofluorêscencia. (A) As imagens demonstram imunoreatividade para astrócitos, através do anticorpo GFAP (verde). A análise foi realizada por microscopia confocal. Barra de escala de $250 \mu \mathrm{m}$. (B) A intensidade do sinal GFAP foi determinado como intensidade média no corno dorsal da medula em secções da L5 e expressos como média \pm E.P.M. de 4 animais por grupo $(* * p<0,01$, ipsilateral vs. contralateral; ${ }^{\#} \mathrm{p}<0,05, \mathrm{NOD}^{-/-} \mathrm{CDi}$ vs. WT CDi; ${ }^{\&} \mathrm{p}<0,05 \mathrm{NOD}^{-/-} \mathrm{CVi}$ vs. WT CVi). 

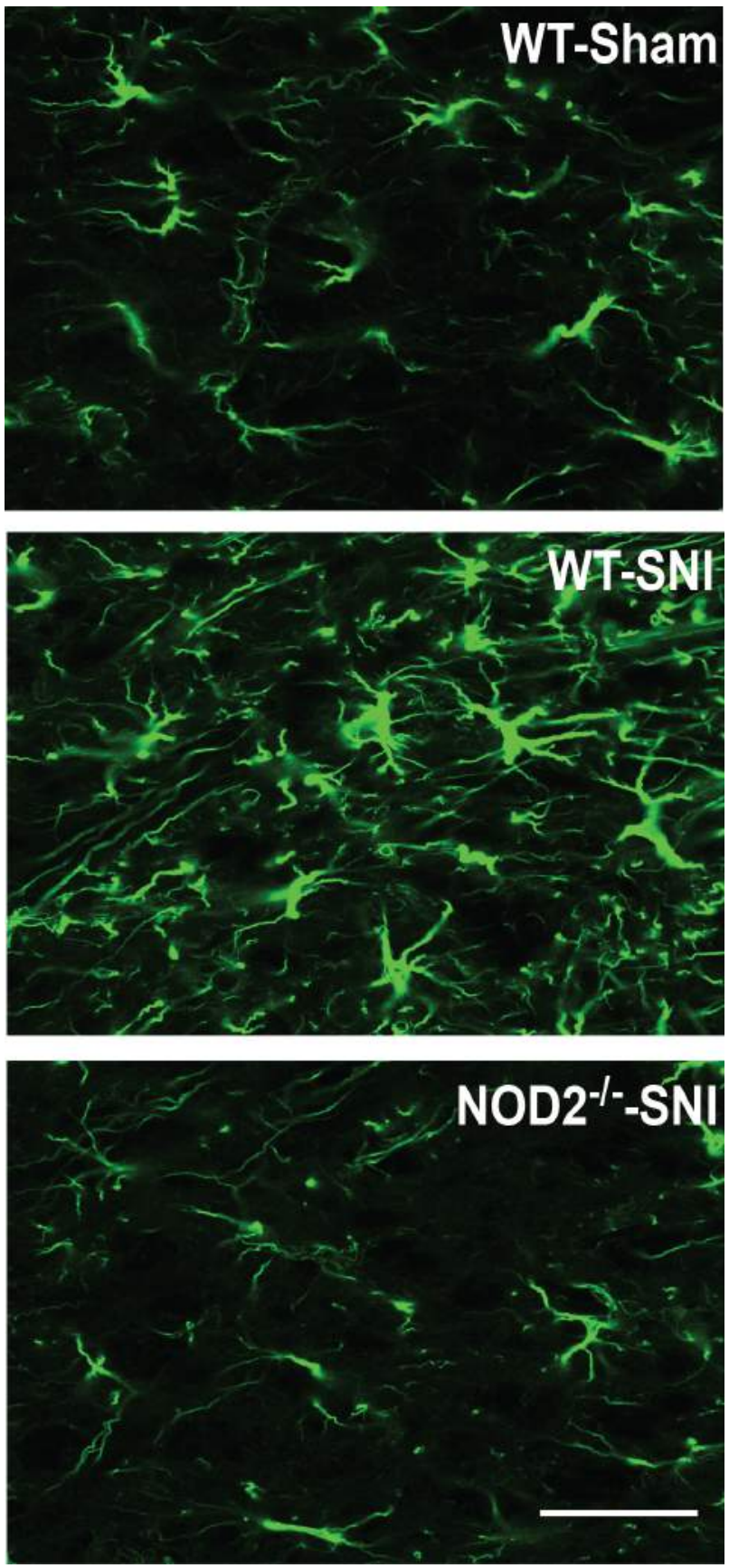

Figura 17. NOD2 é requerido para ativação astrocitária na medula espinal após lesão nervosa periférica. As imagens demonstram uma ampliação de uma região do corno dorsal da medula espinal, apresentando imunoreatividade para astrócitos, através do anticorpo GFAP (verde). A análise foi realizada por microscopia confocal. Barra de escala de $25 \mu \mathrm{m}$. 


\subsection{NOD1 e NOD2 induzem a liberação de citocinas pró-inflamatórias após indução de neuropatia periférica}

Após a indução de neuropatia periférica, a ativação de células da glia na medula espinal promove a liberação de proteínas imunes clássicas em resposta a sinais neuronais, incluindo citocinas pró-inflamatórias como a IL-1 $\beta$, IL-6 e TNF- $\alpha$, implicadas na modulação da sensitividade da dor (Benveniste et al., 1995).

Neste sentido, o próximo passo foi avaliar a participação de NOD1 e NOD2 na indução de citocinas pró-inflamatórias, no sétimo dia pós-neuropatia, visto que neste tempo estabelecido, esses receptores contribuem no processo de ativação glial como demonstrado anteriormente.

Dessa maneira, foi observada pela técnica de ELISA, uma redução significativa na produção de IL-1 $\beta$ e TNF- $\alpha$ na medula espinal de animais NOD1 ${ }^{-/}$e $\mathrm{NOD}^{-/-}$, quando comparadas com o grupo controle positivo WT (Fig. 18), sugerindo envolvimento dos receptores na liberação citocinas pró-inflamatórias pós-neuropatia.
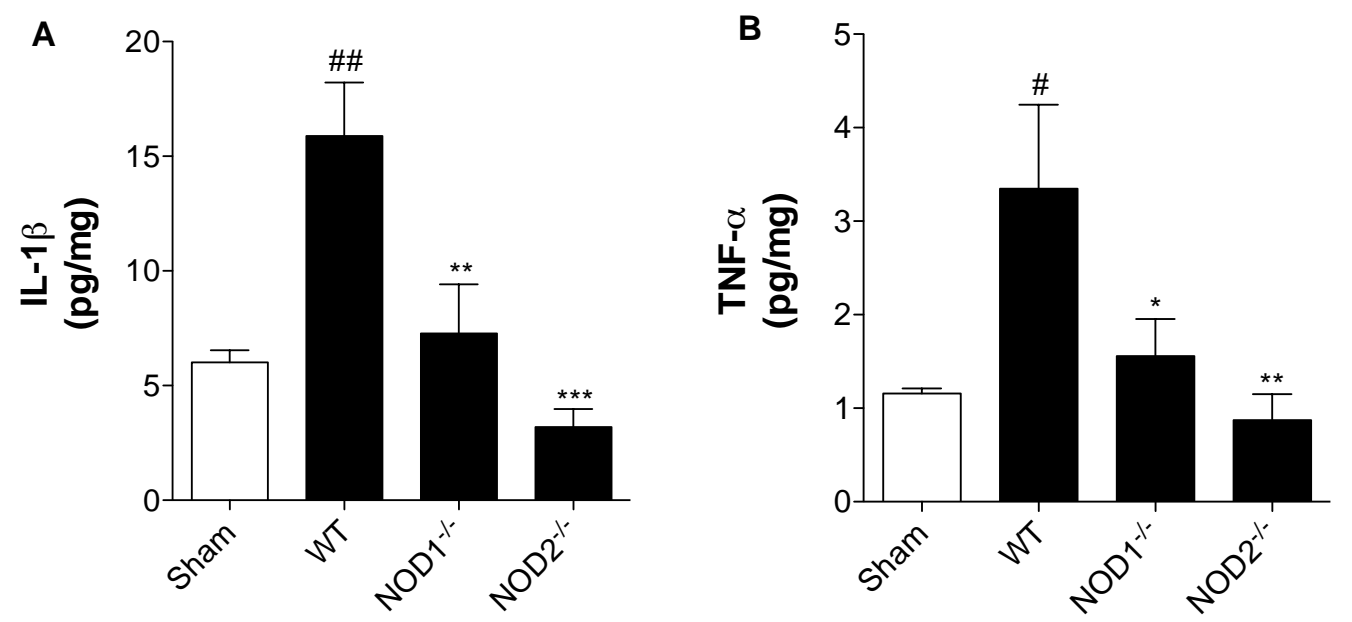

Figura 18. Avaliação da liberação de citocinas pró-inflamatórias em animais NOD1/- e NOD2 ${ }^{-/-}$. Camundongos WT, NOD1 $1^{-/}$e NOD2 $2^{-/-}$foram submetidos a indução de SNI ou falsamente operados (Sham). No sétimo dia após a realização da cirurgia, as medulas espinais foram coletadas para dosagem IL-1 $\beta$ (A) e TNF- $\alpha$ (B) por ELISA. Os dados foram expressos como média \pm E.P.M. de 6 animais por grupo $\left({ }^{\#} \mathrm{p}<0,05 \mathrm{e}^{\# \#} \mathrm{p}<0,01\right.$ quando comparada ao grupo Sham $\mathrm{e}^{*} \mathrm{p}<0,05 ; * * \mathrm{p}<0,01 \mathrm{e} * * * \mathrm{p}<0,001$ quando comparada com grupo WT). 


\subsection{O efeito potencial da ativação de TLR4 e NOD2 reforça a liberação microglial de citocinas pró-inflamatórias}

Trabalhos na literatura têm demonstrado que a ativação sinérgica de NLRs e TLRs é capaz de desencadear uma robusta resposta inflamatória (Wolfert et al., 2002; Natsuka et al., 2008). Dando continuidade ao trabalho, avaliamos a indução de citocinas pró-inflamatórias in vitro, após a estimulação de culturas primárias de micróglia com agonista dos receptores TLR4 (LPS), NOD1 (iE-DAP) e NOD2 (MDP).

Inicialmente, culturas primárias de micróglias foram estimuladas com diferentes concentrações de LPS $(0,1 \mathrm{ng} / \mathrm{mL}-1000 \mathrm{ng} / \mathrm{mL})$. Após 48 horas de estimulação, os sobrenadantes foram coletados e submetidos a análise de TNF- $\alpha, \mathrm{KC}$, IL-6 e IL-1 $\beta$ por ELISA. Como resultado, foi observado um aumento significativo na liberação das citocinas TNF- $\alpha$, KC e IL-6 proporcional ao aumento das doses testadas, quando comparados com o meio de cultura não estimulado (Fig. 19). Já a liberação de IL-1 $\beta$ só foi observada nas doses mais altas de LPS (100ng/mL e $1000 \mathrm{ng} / \mathrm{mL})$.

Quando as culturas primárias foram estimuladas com diferentes concentrações de iE-DAP (10ng/mL-1000ng/mL) e MDP $(1 \mu \mathrm{g} / \mathrm{mL}-10 \mu \mathrm{g} / \mathrm{mL})$, não foi observado aumento na liberação de citocinas pró-inflamatórias, sugerindo que iE-DAP (Fig. 20) e MDP (Fig. 21) sejam fracamente imuno-estimulatório.

Uma vez que esses ligantes não foram capazes de gerar uma resposta, o passo seguinte consistiu em avaliar o efeito da co-estimulação de iE-DAP/MDP com uma concentração sub-máxima de LPS $(0,1 \mathrm{ng} / \mathrm{mL})$, capaz de gerar apenas uma indução branda na liberação de citocinas. Assim sendo, a co-estimulação de iE-DAP e LPS 
não foi capaz de aumentar os níveis das citocinas pró-inflamatórias liberadas quando comparados com o grupo estimulado somente com 0,1ng/mL LPS (Fig. 22). Porém, diferentemente do que foi observado para NOD1, a administração conjunta de MDP e LPS induziu uma robusta reposta caracterizada pela elevada produção de citocinas pró-inflamatórias quando comparados com o grupo não estimulado (Fig. 23). Esse mesmo efeito não foi observado em culturas de micróglia de animais NOD2 ${ }^{-/}$ confirmando assim a ação específica do MDP nos receptores NOD2 (Fig. 24). Não foram detectados níveis mensuráveis da citocina IL-1 $\beta$ em ambos estímulos testados (MDP e iE-DAP) e nas combinações utilizadas com LPS. A somatória dos resultados aponta uma efeito potencial dos receptores NOD2 e TLR4 no intuito de estimular a ativação glial. 

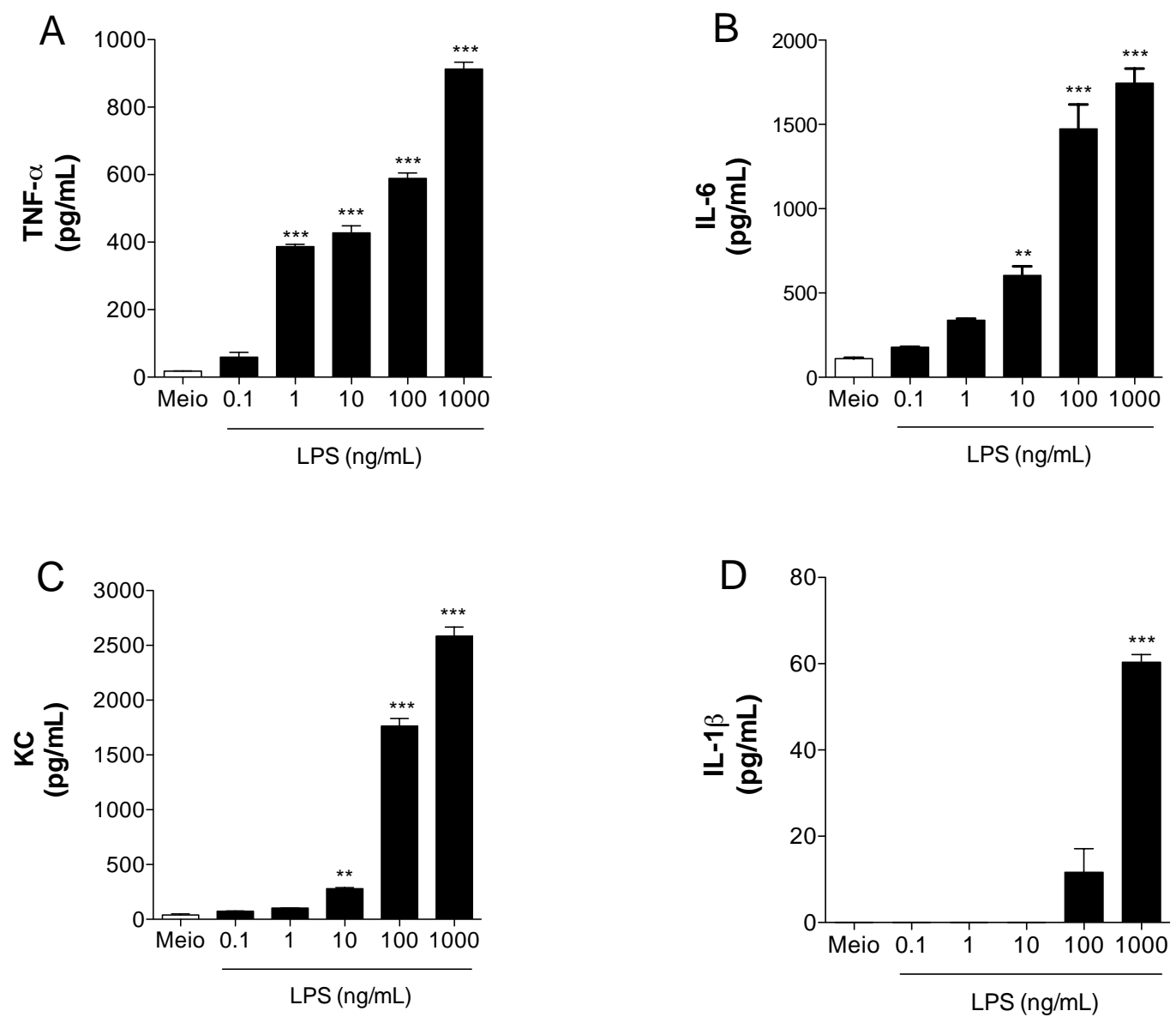

Figura 19. Perfil de expressão de citocinas pró-inflamatórias em culturas de células microgliais estimuladas por LPS. (A-D) Culturas primárias de micróglia foram estimuladas com diferentes concentrações de LPS $(0,1 \mathrm{ng} / \mathrm{mL}, 1 \mathrm{ng} / \mathrm{mL}, 10 \mathrm{ng} / \mathrm{mL}, 100 \mathrm{ng} / \mathrm{mL}$ e $1000 \mathrm{ng} / \mathrm{mL})$. Após 48 horas, os sobrenadantes foram coletados para análise por ELISA de TNF- $\alpha$, IL-6, KC e IL-1 $\beta$ respectivamente. Os dados são expressos como média \pm E.P.M. $\left({ }^{*} \mathrm{p}<0,05 ; * * \mathrm{p}<0,01 \mathrm{e}^{* * *} \mathrm{p}<0,001\right.$ quando comparados ao meio não estimulado). 

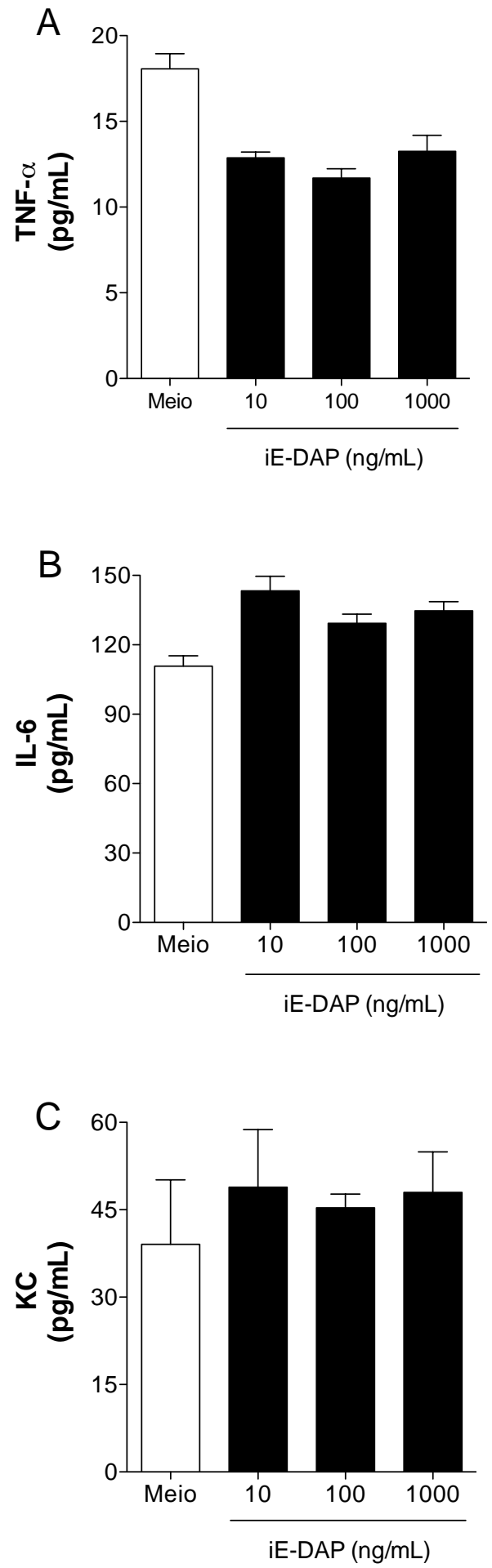

Figura 20. Perfil de expressão de citocinas pró-inflamatórias em culturas de células microgliais estimuladas por iE-DAP. (A-C) Culturas primárias de micróglia foram estimuladas com diferentes concentrações de iE-DAP (10 ng/mL, 100ng/mL e $1000 \mathrm{ng} / \mathrm{mL})$. Após 48 horas, os sobrenadantes foram coletados para análise por ELISA de TNF- $\alpha$, Il-6 e KC respectivamente. Os dados são expressos como média \pm E.P.M. 

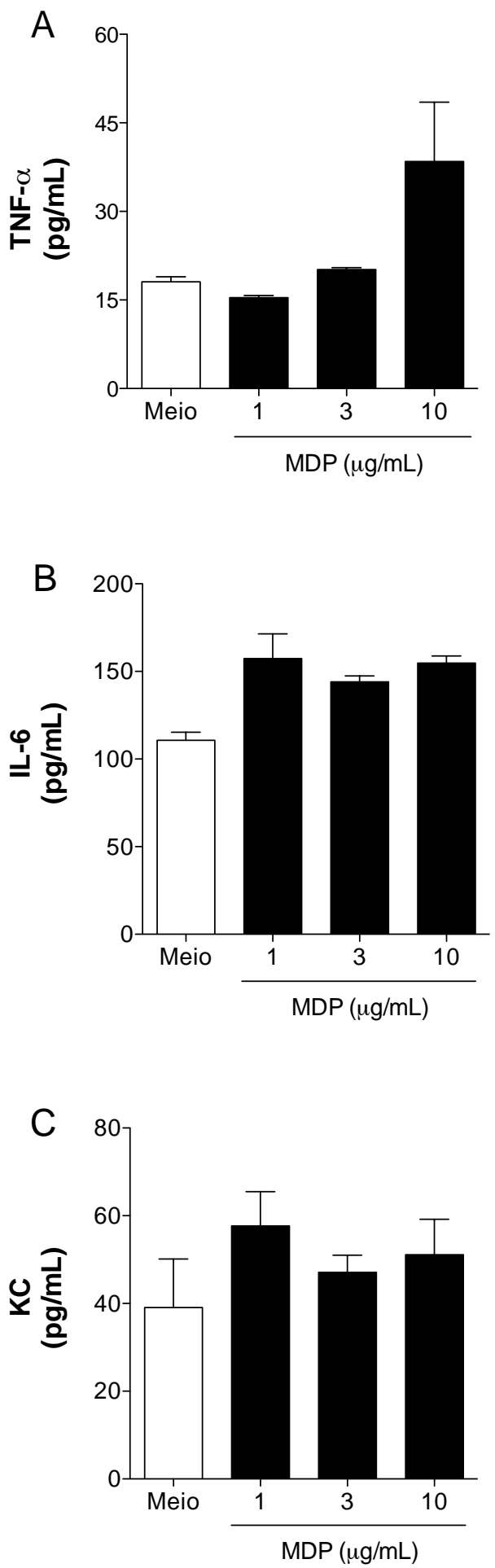

Figura 21. Perfil de expressão de citocinas pró-inflamatórias em culturas de células microgliais estimuladas por MDP. (A-C) Culturas primárias de micróglia foram estimuladas com diferentes concentrações de MDP $(1 \mu \mathrm{g} / \mathrm{mL}, 3 \mu \mathrm{g} / \mathrm{mL}$ e $10 \mu \mathrm{g} / \mathrm{mL})$. Após 48 horas, os sobrenadantes foram coletados para análise por ELISA de TNF- $\alpha$, Il- 6 e KC respectivamente. Os dados são expressos como média \pm E.P.M. 

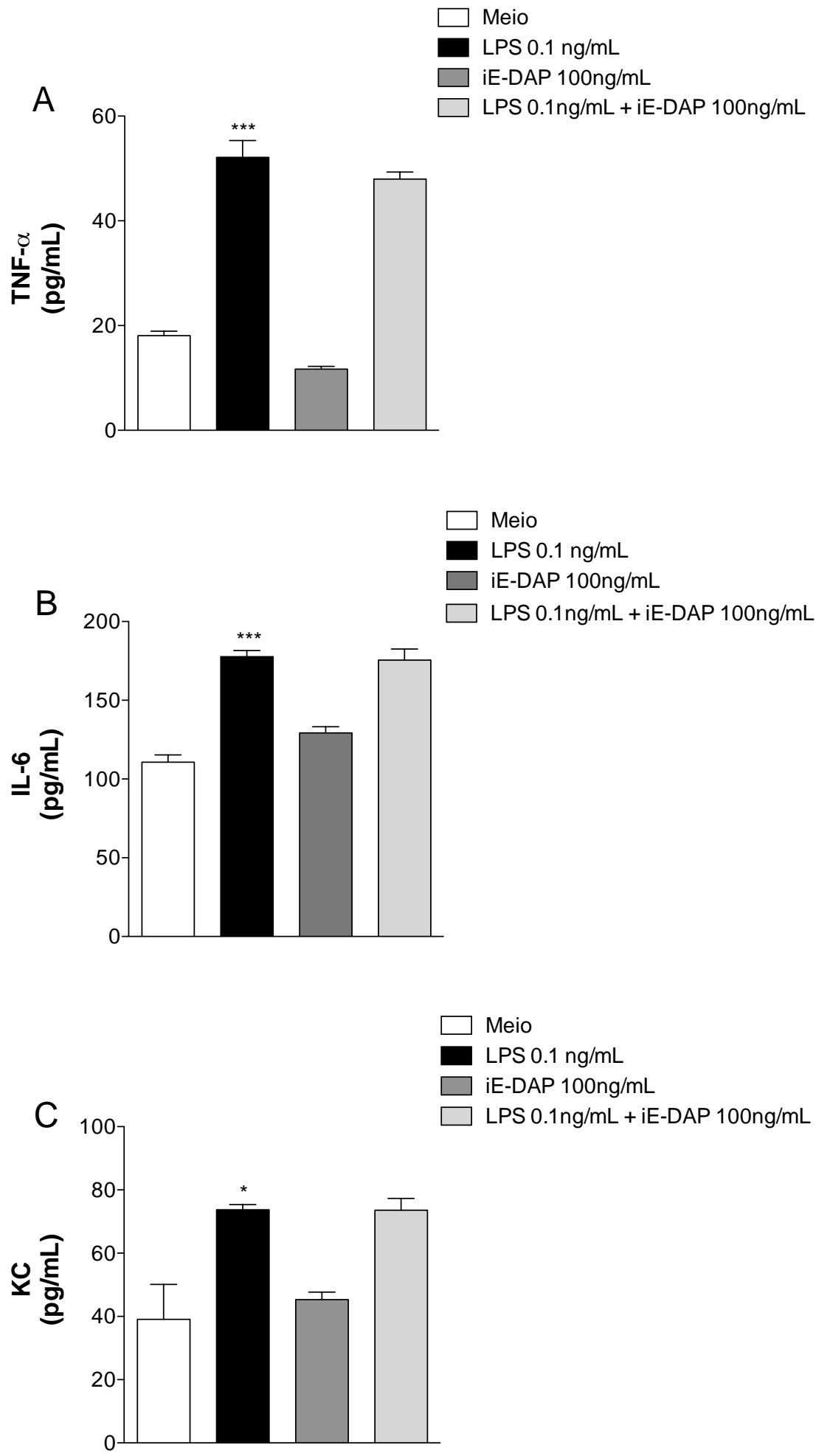

Figura 22. Perfil de expressão de citocinas pró-inflamatórias em culturas de células microgliais estimuladas iE-DAP+LPS. (A-C) Culturas primárias de micróglia foram estimuladas iE-DAP $(100 \mathrm{ng} / \mathrm{mL})+$ LPS $(0,1 \mathrm{ng} / \mathrm{mL})$. Após 48 horas de estimulação os sobrenadantes foram coletados para análise por ELISA de TNF- $\alpha$, IL-6 e KC respectivamente. Os dados são expressos como média \pm E.P.M. $\left({ }^{*} \mathrm{p}<0,05\right.$ e $* * * \mathrm{p}<0,001$ quando comparados ao meio não estimulado). 

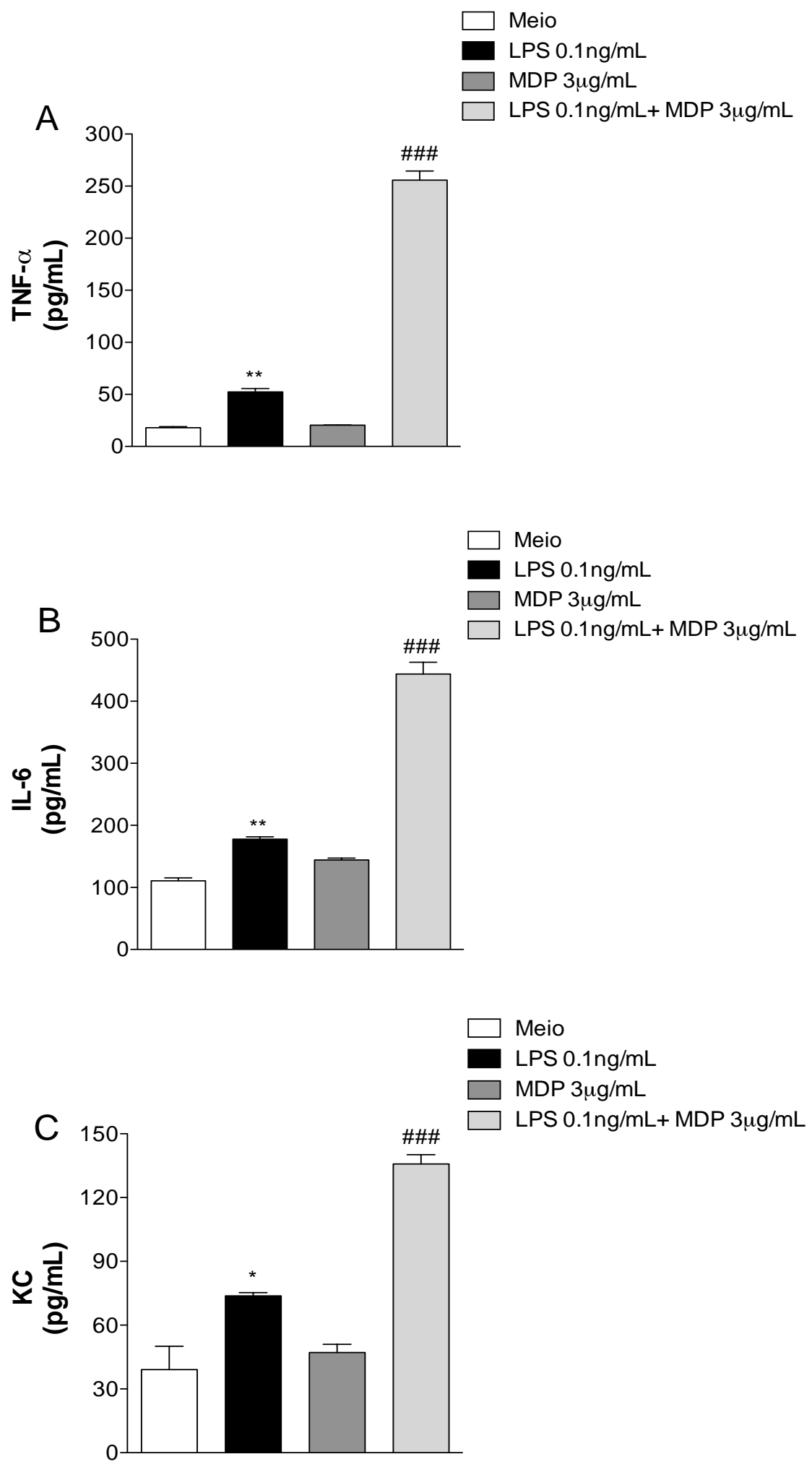

Figura 23. Perfil de expressão de citocinas pró-inflamatórias em culturas de células microgliais estimuladas por MDP+LPS. (A-C) Culturas primárias de micróglia foram estimuladas com MDP $(3 \mu \mathrm{g} / \mathrm{mL})+$ LPS $(0,1 \mathrm{ng} / \mathrm{mL})$. Após 48 horas de estimulação os sobrenadantes foram coletados para análise por ELISA de TNF- $\alpha$, IL- 6 e KC respectivamente. Os dados são expressos como média \pm E.P.M. $\left({ }^{*} \mathrm{p}<0,05\right.$ e ${ }^{* * *} \mathrm{p}<0,001$ quando comparados ao meio não estimulado $\mathrm{e}^{\# \# \#} \mathrm{p}<0,001$ quando comparado ao LPS $0,1 \mathrm{ng} / \mathrm{mL}$ ). 

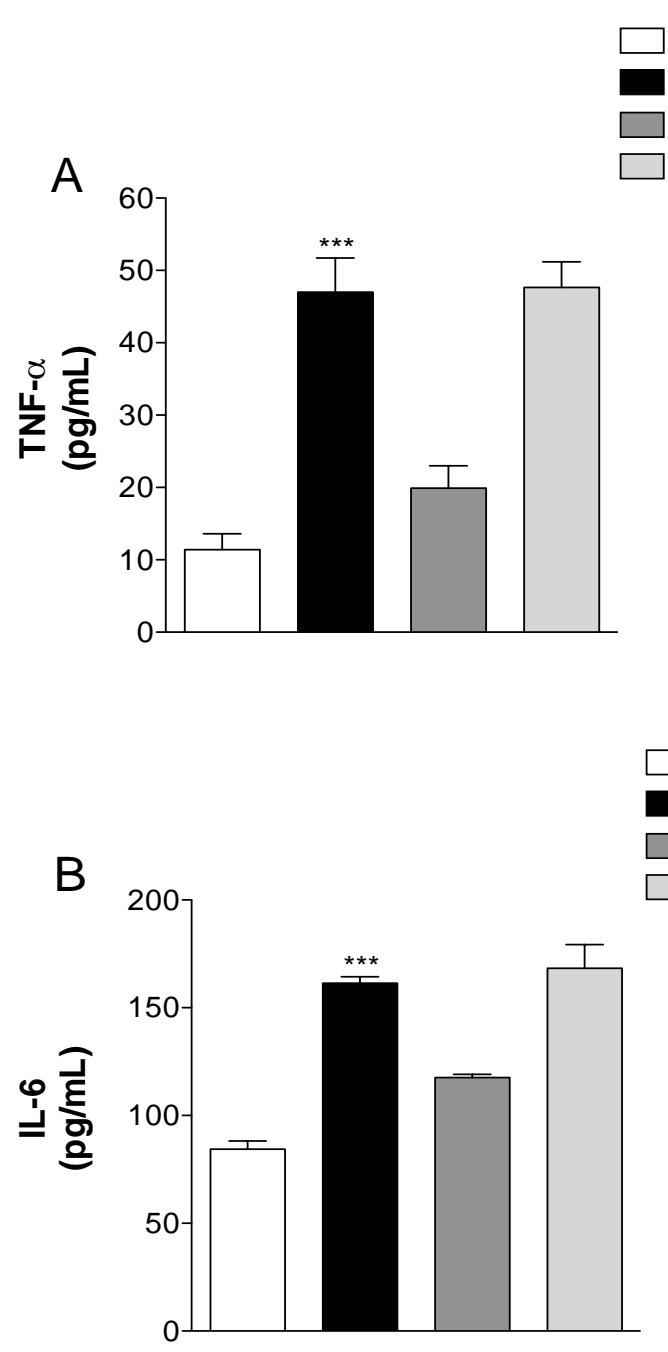

Meio

LPS $0.1 \mathrm{ng} / \mathrm{mL}$

$\square \mathrm{MDP} 3 \mu \mathrm{g} / \mathrm{mL}$

LPS $0.1 \mathrm{ng} / \mathrm{mL}+\mathrm{MDP} 3 \mu \mathrm{g} / \mathrm{mL}$

Meio

LPS $0.1 \mathrm{ng} / \mathrm{mL}$

MDP $3 \mu \mathrm{g} / \mathrm{mL}$

$\square$ LPS $0.1 \mathrm{ng} / \mathrm{mL}+\mathrm{MDP} 3 \mu \mathrm{g} / \mathrm{mL}$

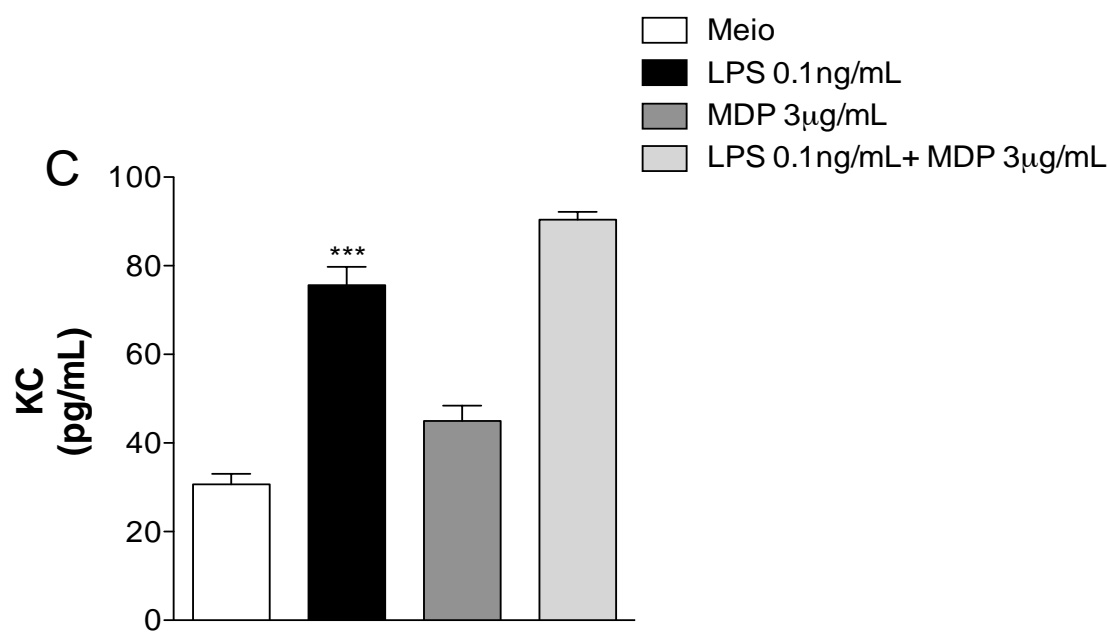

Figura 24. Perfil de expressão de citocinas pró-inflamatórias em culturas de células microgliais NOD2 $^{-/-}$estimuladas por MDP+LPS. (A-C) Culturas primárias de micróglia de animais NOD2 ${ }^{-/-}$ foram estimuladas com MDP $(3 \mu \mathrm{g} / \mathrm{mL})+$ LPS $(0,1 \mathrm{ng} / \mathrm{mL})$. Após 48 horas de estimulação os sobrenadantes foram coletados para análise por ELISA de TNF- $\alpha$, IL- 6 e KC respectivamente. Os dados são expressos como média \pm E.P.M. $(* \mathrm{p}<0,05$ e $* * * \mathrm{p}<0,001$ quando comparados ao meio não

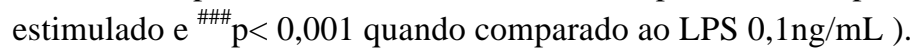


4.10. A via de sinalização dependente de RIPK2 induz hipersensibilidade nociceptiva, ativação glial e liberação de citocinas pró-inflamatórias após indução de neuropatia periférica

Uma vez que os resultados apontam que os receptores NOD1 e NOD2 contribuem para a gênese da dor neuropática, mediando a ativação de células gliais e a liberação de citocinas pró-nociceptivas na medula espinal, o próximo passo foi investigar o papel da quinase RIPK2, recrutada após a ativação desses receptores, nesse processo.

Primeiramente, foi demonstrado que da mesma maneira que os animais WT, animais $\mathrm{RIPK}^{-{ }^{--}}$respondem normalmente frente a diferentes estímulos nociceptivos, como mecânico mediante os filamentos de von Frey (Fig. 25), térmico através do teste da Placa Quente (Fig. 26), e químico, pela administração subplantar de formalina (Fig. 27).

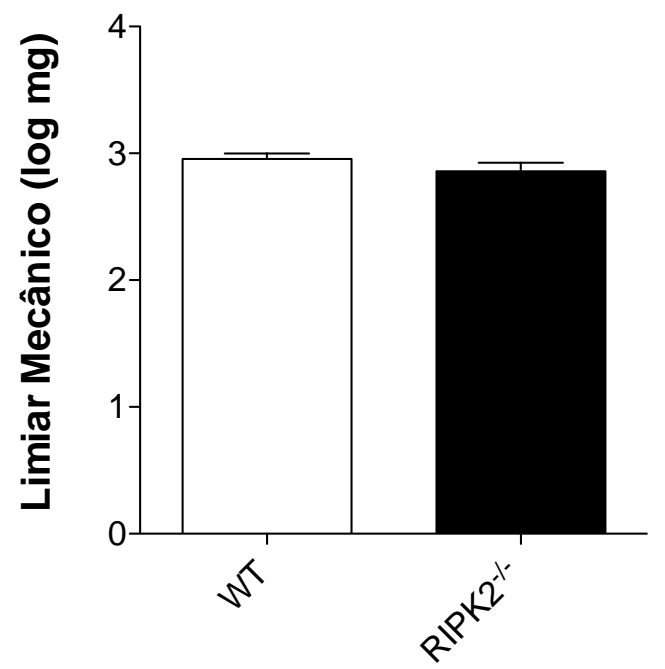

Figura 25. Avaliação da nocicepção mecânica em animais RIPK2 ${ }^{-/}$. Camundongos machos WT e RIPK2 $^{-/-}$foram avaliados quanto à estimulação mecânica, através dos filamentos de von Frey. O filamento de menor força capaz de induzir resposta foi determinado como sendo o limiar mecânico de retirada. Os dados foram expressos como média \pm E.P.M. de 6-8 animais por grupo. 


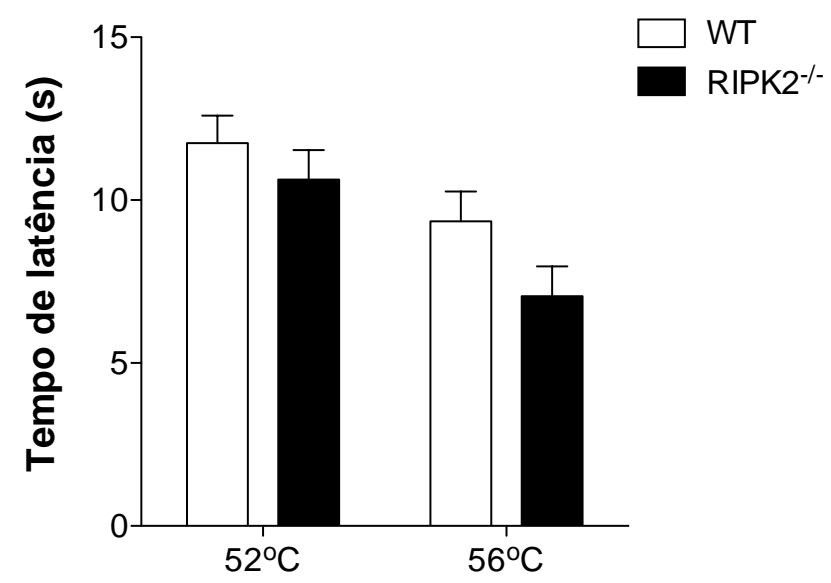

Figura 26. Avaliação da nocicepção térmica em animais RIPK2 ${ }^{-/-}$. Camundongos WT e RIPK2 $2^{-/-}$ foram colocados individualmente na placa quente aquecida a diferentes temperaturas $\left(52^{\circ} \mathrm{C}\right.$ e $\left.56^{\circ} \mathrm{C}\right)$ onde uma resposta característica, na qual o animal troca rapidamente o apoio dos pés, levanta ou lambe uma das patas é avaliado. Os resultados foram expressos como a latência para o aparecimento desta resposta em segundos. Os dados foram expressos como média \pm E.P.M. de 6-8 animais por grupo.

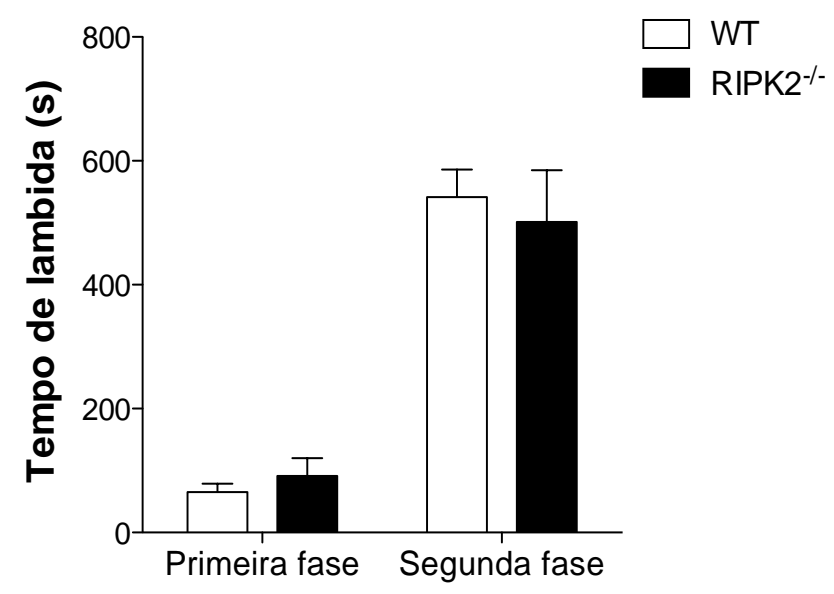

Figura 27. Avaliação da nocicepção química em animais RIPK2 ${ }^{-/}$. Camundongos WT e RIPK2 $2^{-/-}$ receberam administração subplantar de uma solução de formalina $1 \%$ na pata traseira direita. O tempo de lambida foi então cronometrado a cada 5 minutos durante um período total de 50 minutos. Os resultados foram expressos como tempo de lambida (s) em relação a $1^{\text {a }}$ fase (0-10 min) e $2^{\text {a }}$ fase (10-50 min). Os dados foram expressos como média \pm E.P.M de 6-8 animais por grupo.

Em seguida, avaliou-se o desenvolvimento da dor neuropática em animais $\mathrm{RIPK}^{-/-}$machos e fêmeas. Após a realização da cirurgia, foi observado que o limiar de retirada da pata dos animais WT começou a diminuir no terceiro dia após a lesão do nervo, e atingiu o limiar mínimo no décimo quarto dia para os machos $(1,69 \pm 0,13$ $\log \mathrm{mg})$ e para as fêmeas $(1,58 \pm 0,20 \log \mathrm{mg})$, quando comparado aos seus respectivos limiares basais $(3,00 \pm 0.00 \mathrm{log} \mathrm{mg}$ para machos e 2,77 $\pm 0.00 \mathrm{log} \mathrm{mg}$ 
para as fêmeas). Já os animais RIPK2 ${ }^{-/-}$atingiram o limiar mínimo também no décimo quarto dia, no entanto, reduziram apenas para 2,36 $\pm 0,21$ log mg para machos (Fig. 28A) e para 2,03 $\pm 0,23 \log \mathrm{mg}$ para as fêmeas (Fig. 28B), em comparação com o seus respectivos limiares basais $(2,91 \pm 0,12 \log \mathrm{mg}$ para machos e 2,77 $\pm 0,00 \log \mathrm{mg}$ para fêmeas).

Portanto, ambos os sexos dos animais RIPK $2^{-/-}$reduziram a hipersensibilidade nociceptiva mecânica, quando comparado aos animais WT, sugerindo que NOD1 e NOD2, via RIPK2, contribuem para gênese da dor neuropática.

A

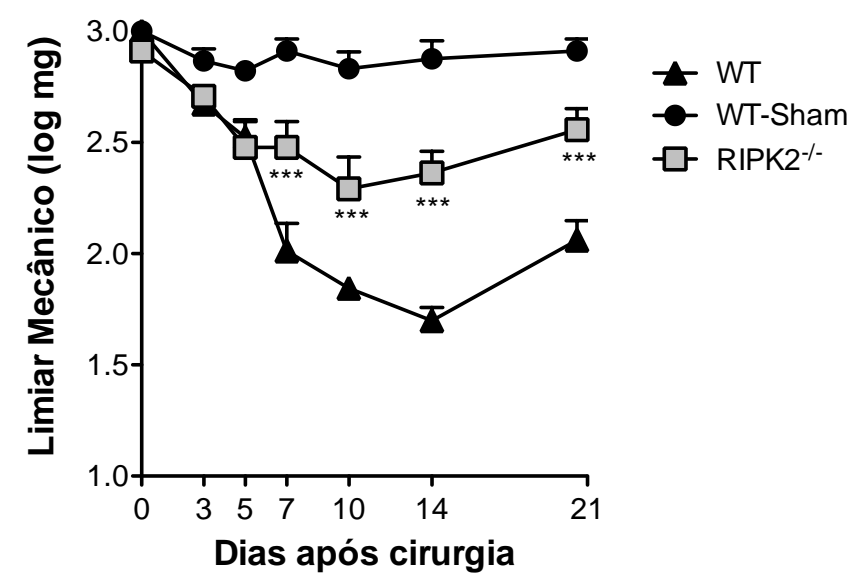

B

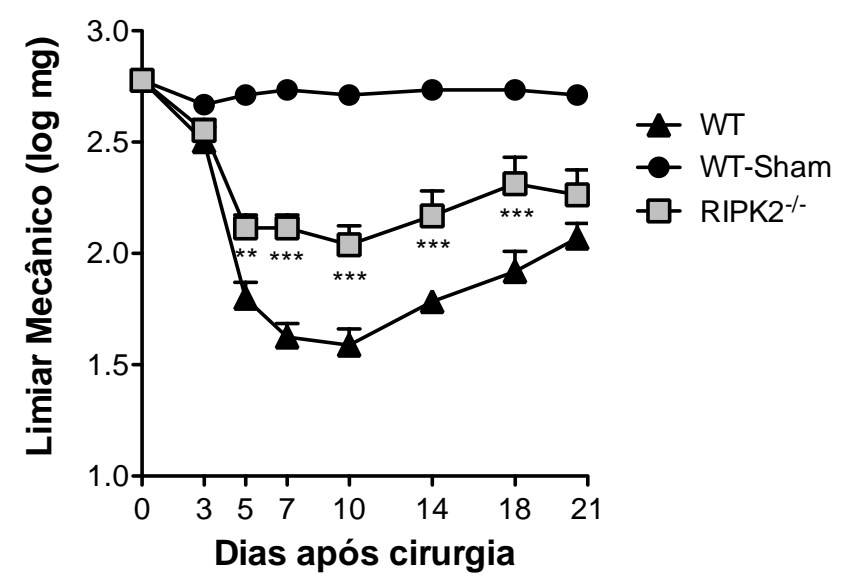

Figura 28. Avaliação da nocicepção mecânica em animais RIPK2 ${ }^{-/}$submetidos à neuropatia periférica. Camundongos WT e RIPK $2^{-/-}$machos (A) e fêmeas (B) foram submetidos a indução de SNI ou falsamente operados (Sham) e, após, avaliados quanto à estimulação mecânica, através dos filamentos de von Frey, durante um período de 21 dias. Os dados foram expressos como média \pm E.P.M. de 8 animais por grupo. ( ${ }^{*} \mathrm{p}<0,05 ;{ }^{* *} \mathrm{p}<0,01 ; * * * \mathrm{p}<0,001$ quando comparada ao grupo WT). 
Com relação ao processo de indução e manutenção da dor crônica inflamatória, foi observado que ambos animais WT e RIPK2 ${ }^{-/}$, administrados com CFA, apresentaram uma redução no limiar de retirada da pata, ou seja, um aumento da sensibilidade mecânica. No grupo WT-CFA, o limiar de retirada da pata atingiu o limiar mínimo no terceiro dia $(1,49 \pm 0,22 \log \mathrm{mg})$, em comparação com o limiar basal antes da cirurgia $(2,81 \pm 0,09 \log \mathrm{mg})$, enquanto que para os animais RIPK2 ${ }^{-/-}$ CFA foi de 1,81 \pm 0,24 log mg (Fig. 29), comparando-se ao seu limiar basal de 2,82 \pm 0,09 log mg. Já nos animais controles administrados com salina (WT-veículo e RIPK $2^{-/-}$-veículo), não foi observada redução significativa no limiar de retirada da pata, que se manteve próximo ao limiar basal durante toda a avaliação (Fig. 29).

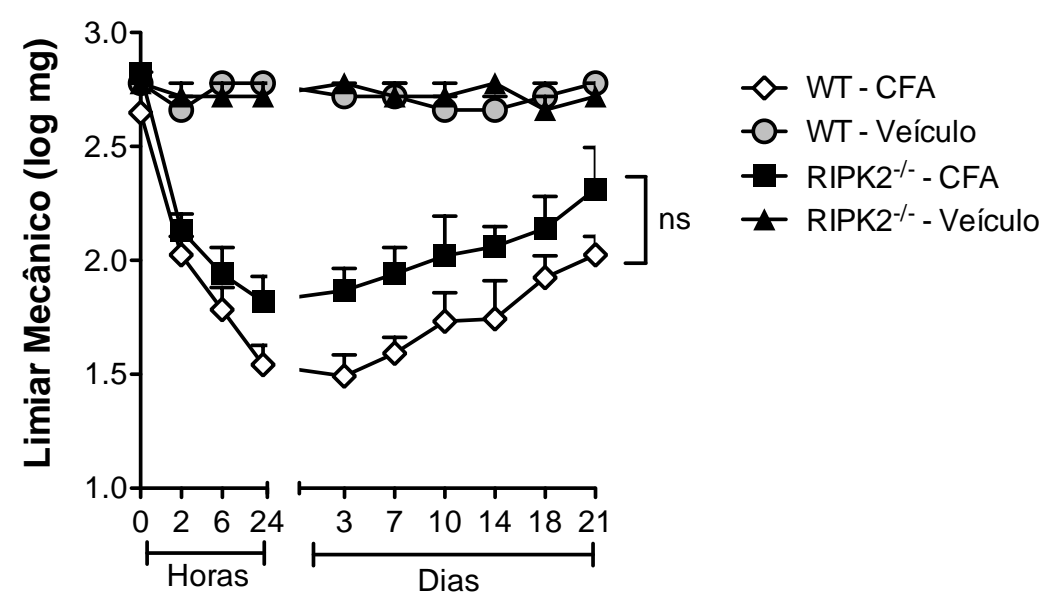

Figura 29. Avaliação da nocicepção mecânica em camundongos RIPK2 ${ }^{-/-}$submetidos à inflamação periférica. Camundongos WT e RIPK2 $2^{-/-}$foram submetidos à administração i.pl. de CFA ou salina na pata posterior direita e, após, avaliados quanto à estimulação mecânica, através dos filamentos de von Frey, durante um período de 21 dias. Os dados foram expressos como média \pm E.P.M. de 8 animais por grupo. 
Uma vez determinado o papel da via de sinalização dependente de RIPK2, na hipersensibilidade mecânica após a indução de neuropatia periférica, nosso próximo objetivo foi avaliar o possível envolvimento dessa quinase na ativação de células da glia na medula espinal.

Da mesma maneira que observado para $\mathrm{NOD}^{-{ }^{--}} \mathrm{e} \mathrm{NOD}^{-{ }^{--}}$, os animais RIPK2 $2^{-}$ /- também apresentaram uma redução significativa na expressão de IBA-1 no sétimo e décimo dia após neuropatia quando comparada ao grupo WT (Fig. 30), tanto por RTqPCR como também por imunofluorescência (Fig. 31 e 32). Além disso, esses animais também apresentaram uma redução na expressão de GFAP no sétimo dia pósneuropatia, comparado ao grupo WT (Fig. 33), sugerindo participação de RIPK2 na ativação microglial e astrocitária no decorrer do processo neuropático.
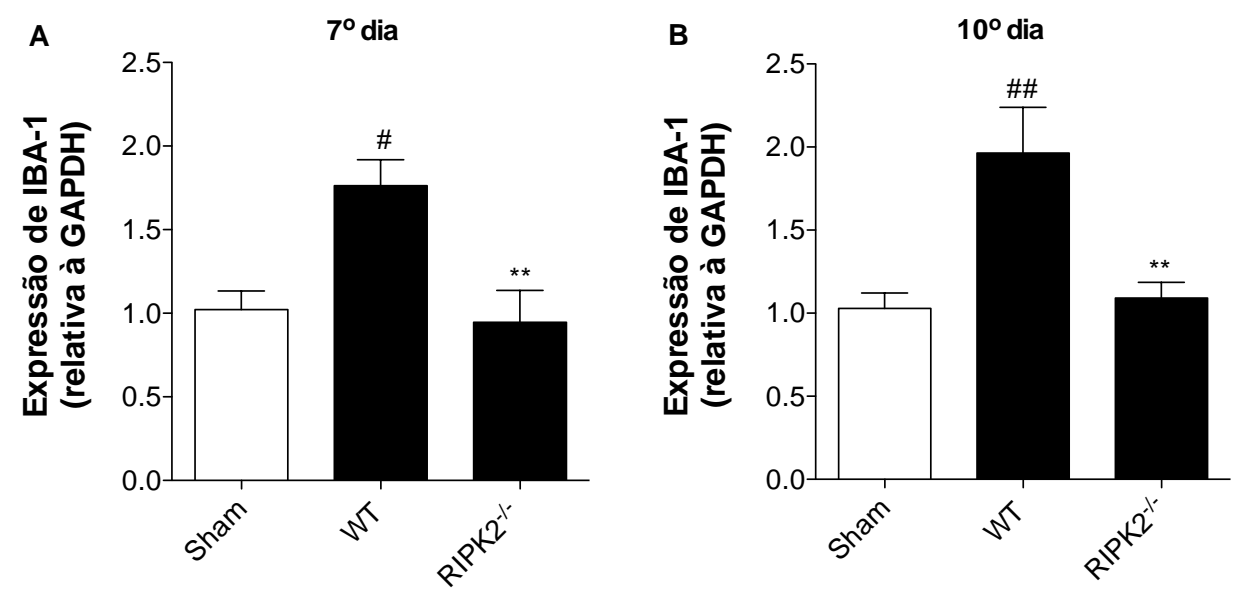

Figura 30. Avaliação da ativação de micróglia em camundongos RIPK2 ${ }^{-/}$. Camundongos WT e RIPK2 $^{-/-}$foram submetidos a indução de SNI ou falsamente operados (Sham). Nos dias 7 e 10 póscirurgia, as medulas espinais foram coletadas para análise da expressão de IBA-1 por RT-qPCR. Os dados foram normalizados em relação à expressão da GAPDH e expressos como média \pm E.P.M. de 8 animais por grupo $\left({ }^{\#} \mathrm{p}<0,05 ;{ }^{\# \#} \mathrm{p}<0,01\right.$ quando comparada ao grupo Sham e $* * \mathrm{p}<0,01$ quando comparada com grupo WT). 

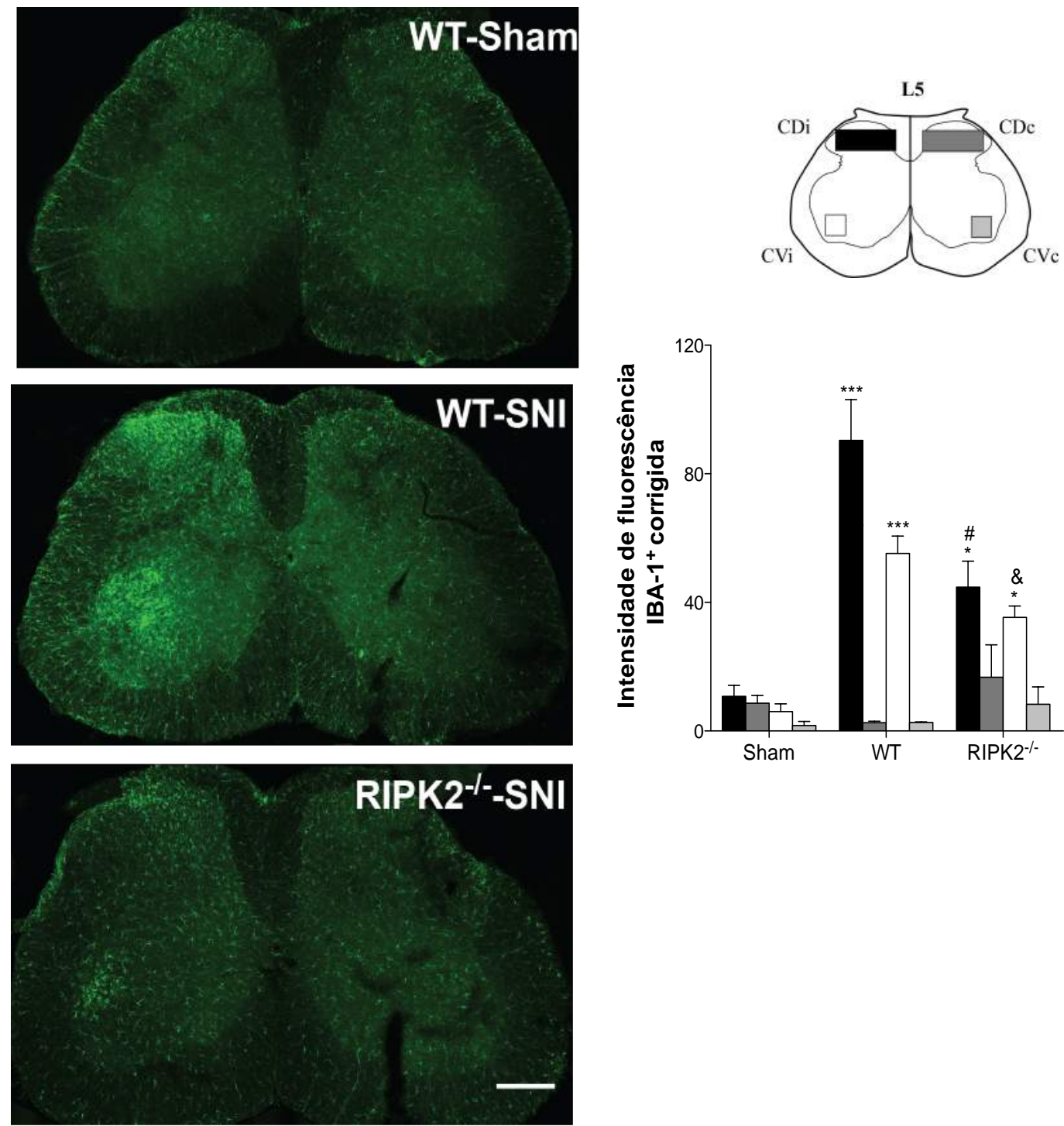

Figura 31. RIPK2 é requerido para ativação microglial na medula espinal após lesão nervosa periférica. Camundongos WT e RIPK $2^{-/-}$foram submetidos a indução de SNI ou falsamente operados (Sham). No dia 10 pós-cirurgia, as medulas espinais foram coletadas para análise por imunofluorêscencia. As imagens demonstram imunoreatividade para micróglia, através do anticorpo IBA-1 (verde). A análise foi realizada por microscopia confocal. Barra de escala de $250 \mu \mathrm{m}$ (esquerda). A intensidade do sinal IBA-1 foi determinado como intensidade média em regiões especificas de interesse em secções da L5 e expressos como média \pm E.P.M. de 4 animais por grupo $(* * p<0,01$ e $* * * \mathrm{p}<0,001$, ipsilateral vs. Contralateral; ${ }^{\#} \mathrm{p}<0,05, \mathrm{RIPK} 2^{-/-} \mathrm{CDi}$ vs. WT CDi; ${ }^{\&} \mathrm{p}<0,05 \mathrm{NOD}^{-/-} \mathrm{CVi}$ vs. WT CVi) (direita). 

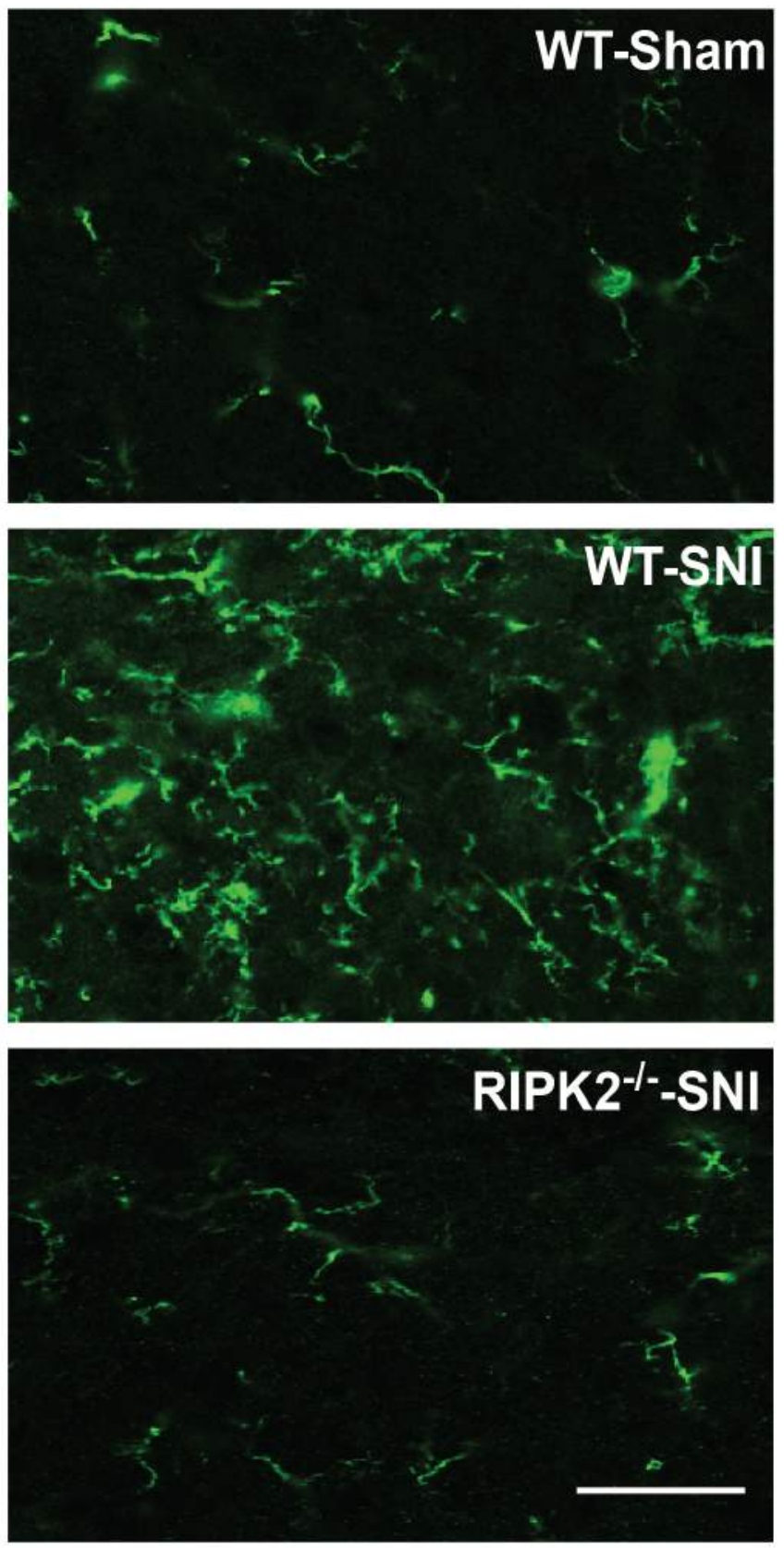

Figura 32. RIPK2 é requerido para ativação microglial na medula espinal após lesão nervosa periférica. As imagens demonstram uma ampliação de uma região do corno dorsal da medula espinal, apresentando imunoreatividade para micróglia, através do anticorpo IBA-1 (verde). A análise foi realizada por microscopia confocal. Barra de escala de $25 \mu \mathrm{m}$. 


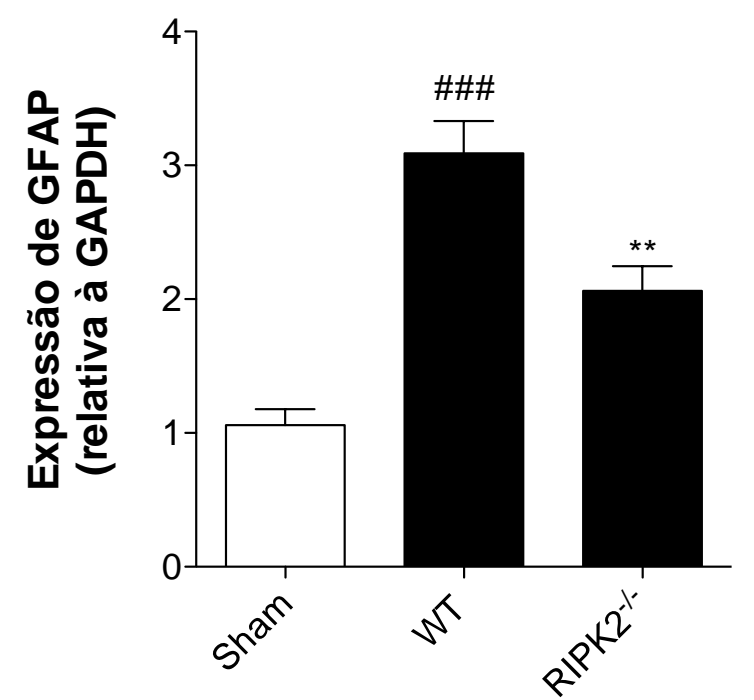

Figura 33. Avaliação da ativação de astrócitos em camundongos RIPK2 ${ }^{-/-}$. Camundongos WT e RIPK2 $^{-/-}$foram submetidos a indução de SNI ou falsamente operados (Sham). No dia 7 pós-cirurgia, as medulas espinais foram coletadas para análise da expressão de GFAP por RT-qPCR. Os dados foram normalizados em relação à expressão da GAPDH e expressos como média \pm E.P.M. de 8 animais por grupo $\left({ }^{\# \#} \mathrm{p}<0,001\right.$ quando comparada ao grupo Sham $\mathrm{e}^{* *} \mathrm{p}<0,01$ quando comparada com grupo WT).

Para finalizar, foi avaliado o envolvimento da via RIPK2 na indução de citocinas pró-inflamatórias. Assim, uma redução significativa na produção de IL-1 $1 \beta$ e TNF- $\alpha$ na medula espinal de animais RIPK $2^{-/-}$foi observada, quando comparadas com o grupo controle positivo WT (Fig. 34).

A somatória de todos esses resultados apontam contribuição da via de sinalização dependente de RIPK2 na hipersensibilidade nociceptiva mecânica, indução de citocinas pró-inflamatórias e ativação das células gliais na medula espinal, após indução de neuropatia periférica 

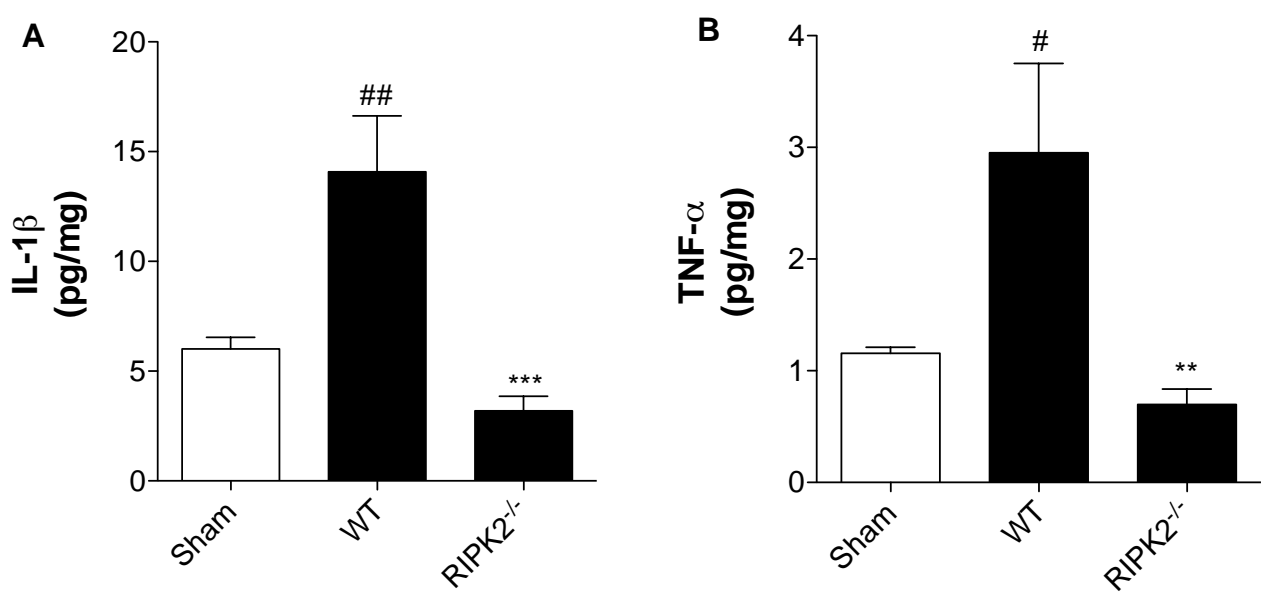

Figura 34. Avaliação da liberação de citocinas pró-inflamatórias em animais RIPK2 ${ }^{-/}$. Camundongos WT e RIPK2 $2^{--}$foram submetidos a indução de SNI ou falsamente operados (Sham). No sétimo dia após a realização da cirurgia, as medulas espinais foram coletadas para dosagem IL-1 $\beta$ (A) e TNF- $\alpha$ (B) por ELISA. Os dados foram expressos como média \pm E.P.M. de 6 animais por grupo $\left({ }^{\#} \mathrm{p}<\right.$ $0,05 \mathrm{e}^{\# \#} \mathrm{p}<0,01$ quando comparada ao grupo Sham $\mathrm{e}^{* *} \mathrm{p}<0,01 \mathrm{e}^{* * *} \mathrm{p}<0,001$ quando comparada com grupo WT).

\subsection{NOD1 e NOD2, via RIPK2, contribuem para a expressão de P2X4 após indução de neuropatia periférica}

Recentes descobertas sugerem que a ativação de P2X4, expressos na micróglia, contribuem para o processo de desenvolvimento da dor neuropática (Coull et al., 2005). Ainda, foi demonstrado que os receptores TLRs e NLRs cooperam na ativação da micróglia levando a um aumento da expressão de P2X4 e, consequentemente, liberação de citocinas (Guo et al., 2006). Baseado nisso, um dos objetivos do trabalho foi avaliar o envolvimento dos receptores NOD1 e NOD2 na ativação de P2X4 durante o processo de neuropatia periférica.

Inicialmente, foi determinado por RT-qPCR o perfil de expressão de P2X4 em animais WT submetidos à cirurgia de SNI. Como resultado, foi observado um aumento significativo na expressão de P2X4 no dias 7, 10 e 14 após a indução de neuropatia, quando comparada ao grupo Sham (Fig. 35). No pico de expressão de 
P2X4 nos animais WT, ou seja, no décimo quarto dia pós-neuropatia, os animais $\mathrm{NOD}^{-{ }^{--}}, \mathrm{NOD}^{-{ }^{--}}$e RIPK2${ }^{-/-}$apresentaram uma redução na expressão desse receptor de ATP, apontando um papel de NOD1 e NOD2, via RIPK2, na expressão de P2X4 após neuropatia periférica (Fig. 36).

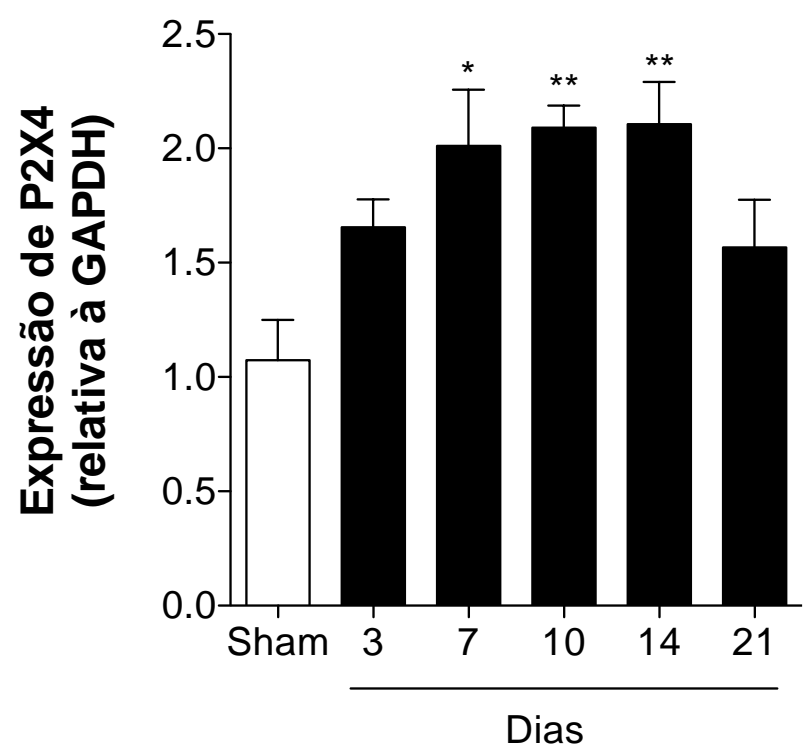

Figura 35. Perfil de expressão de P2X4 em camundongos após indução de neuropatia periférica. Camundongos WT foram submetidos a indução de SNI ou falsamente operados (Sham). Nos dias 3, 7, 10, 14 e 21 pós-cirurgia, as medulas espinais foram coletadas para análise da expressão de P2X4 por RT-qPCR. Os dados foram normalizados em relação à expressão da GAPDH e expressos como média \pm E.P.M. de 8 animais por grupo ( ${ }^{*} \mathrm{p}<0,05 ; * * \mathrm{p}<0,01$ quando comparada ao grupo Sham). 


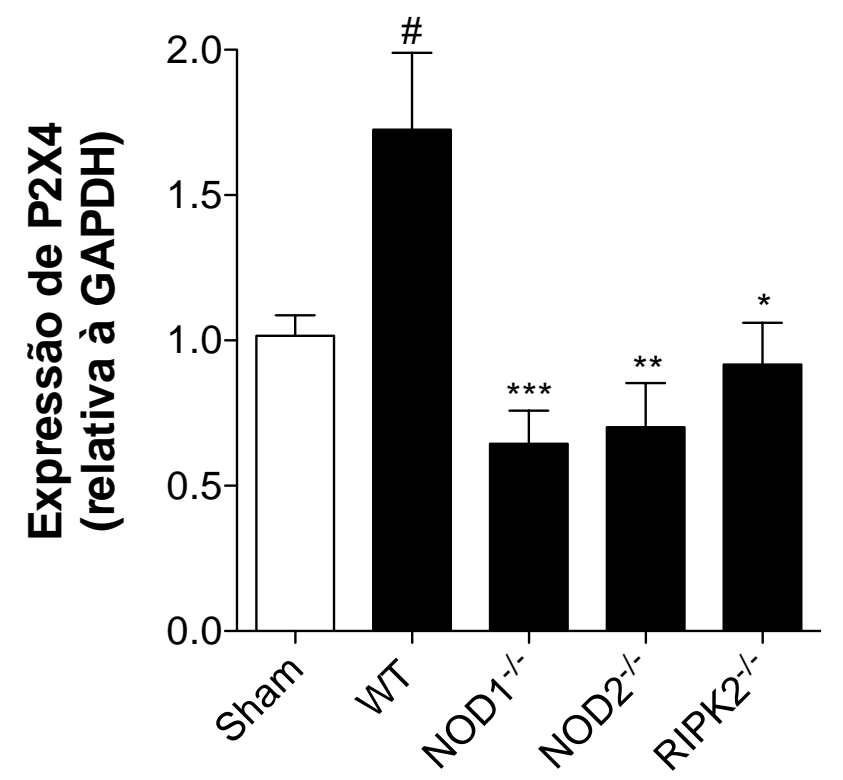

Figura 36. Avaliação da expressão de P2X4 em camundongos NOD1 ${ }^{-/}$, NOD2 $2^{-/-}$e RIPK2 ${ }^{-/-}$. Camundongos WT, NOD $1^{-/-}$, NOD2 $2^{-/-}$e RIPK2 $2^{--}$foram submetidos a indução de SNI ou falsamente operados (Sham). No dia 14 pós-cirurgia, as medulas espinais foram coletadas para análise da expressão de P2X4 por RT-qPCR. Os dados foram normalizados em relação à expressão da GAPDH e expressos como média \pm E.P.M. de 8 animais por grupo ${ }^{\#} \mathrm{p}<0,05$ quando comparada ao grupo Sham e $* \mathrm{p}<0,05 ; * * \mathrm{p}<0,01 \mathrm{e} * * * \mathrm{p}<0,001$ quando comparada com grupo WT).

\subsection{Papel do infiltrado de células periféricas derivadas da medula óssea na ativação microglial mediada por NOD1 e NOD2 após indução de neuropatia periférica}

Para avaliar a contribuição das células imunes periféricas na processo neuropático induzido por NOD1 e NOD2, uma vez já descrita a elevada expressão desses receptores nas células hematopoiéticas (Ogura et al., 2001), camundongos quimeras de medula óssea foram gerados. Animais WT, NOD1 ${ }^{-/-}$e $\mathrm{NOD}^{-/-}$foram repovoados com células tronco provenientes da medula óssea de animais $\mathrm{GFP}^{+} \mathrm{e}$ submetidos a indução de neuropatia periférica. Como padronização, foi verificado por citometria de fluxo que 60 dias após a transferência de medula óssea, aproximadamente $80-95 \%$ das células do baço, linfonodo e sangue periférico dos camundongos foram substituídos por células $\mathrm{GFP}^{+}$, indicando eficiência na produção 
dos animais quimeras (Fig. 37).
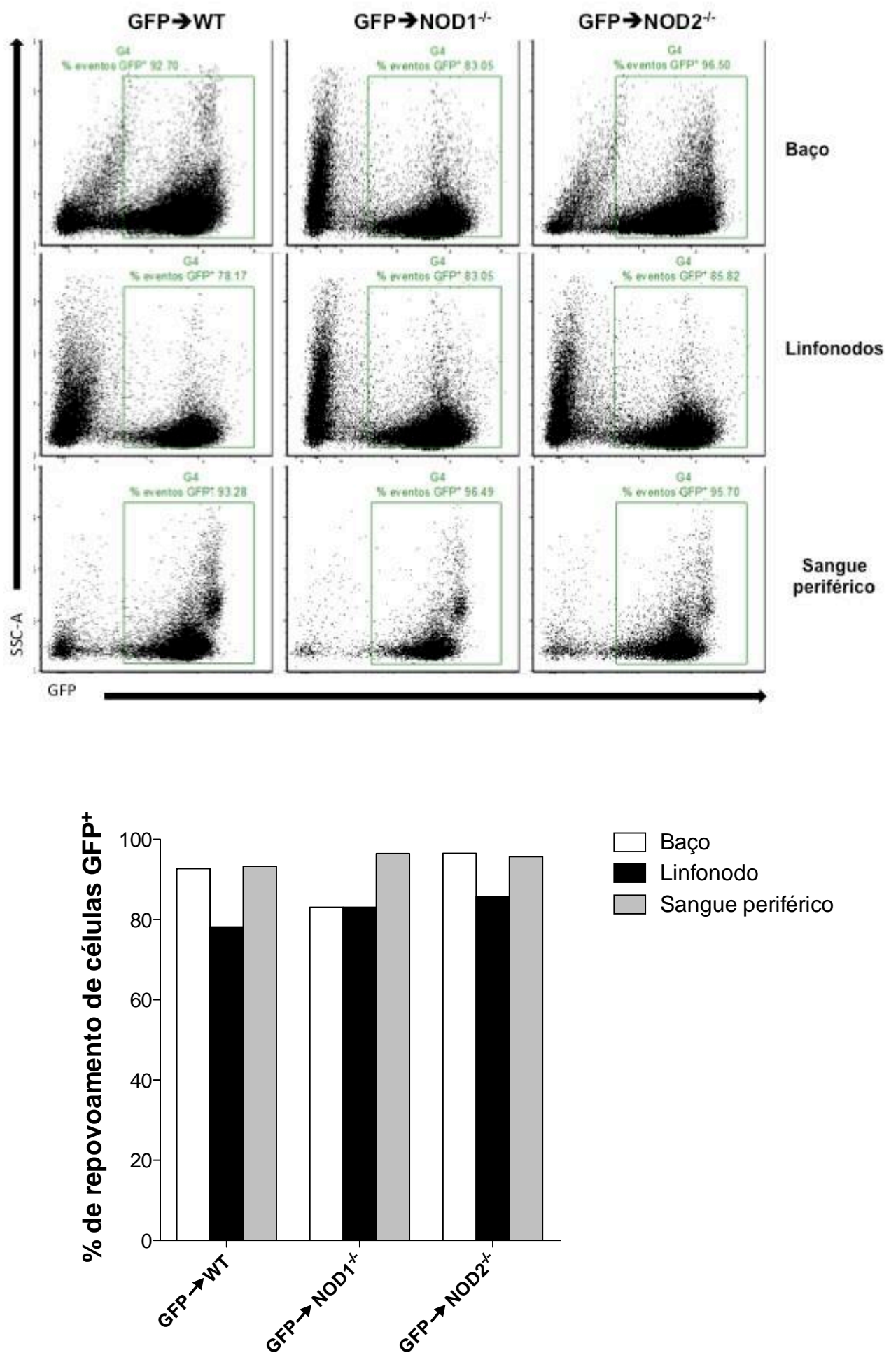

Figura 37. Padronização da construção de animais quimeras, selvagens e deficientes para NOD1 e NOD2. Camundongos WT, $\mathrm{NOD}^{-{ }_{-}}$e NOD2 $2^{-{ }_{-}}$foram transplantados com células tronco provenientes da medula óssea de animais $\mathrm{GFP}^{+}$. Após 60 dias do "pega medular", amostras de células do baço, linfonodo e sangue periférico dos camundongos foram avaliados quanto a eficiência no repovoamento de células $\mathrm{GFP}^{+}$por citometria de fluxo. 
Dados da literatura demonstram que o infiltrado espinal de células imunes periféricas na medula é máximo entre 7 a 21 dias após a indução de neuropatia periférica (Sweitzer et al., 2002; Zhang et al., 2007; Costigam et al., 2009; Isami et al., 2013). Nosso objetivo consistiu em avaliar a ativação microglial (IBA-1) e o infiltrado dessas células periféricas $\left(\mathrm{GFP}^{+}\right)$na medula espinal em animais quimeras de medula óssea, no décimo dia pós-neuropatia, uma vez padronizado ser o dia de pico de ativação microglial.

Por microscopia confocal, células ramificadas expressando $\mathrm{GFP}^{+}$foram observadas no corno dorsal e ventral ipsilateral da medula espinal tanto de animais WT como também NOD1 ${ }^{-/-}$e NOD2 $2^{-/}$, quando comparadas ao lado contralateral (Fig. 38). Diferentemente, nos animais Sham, uma pequena quantidade de células $\mathrm{GFP}^{+}$, possuindo formato alongado e não ramificado, foi percebida na medula, apesar de não haver diferença significativa entre os lados ipsilateral e contralateral (Fig. 39). 

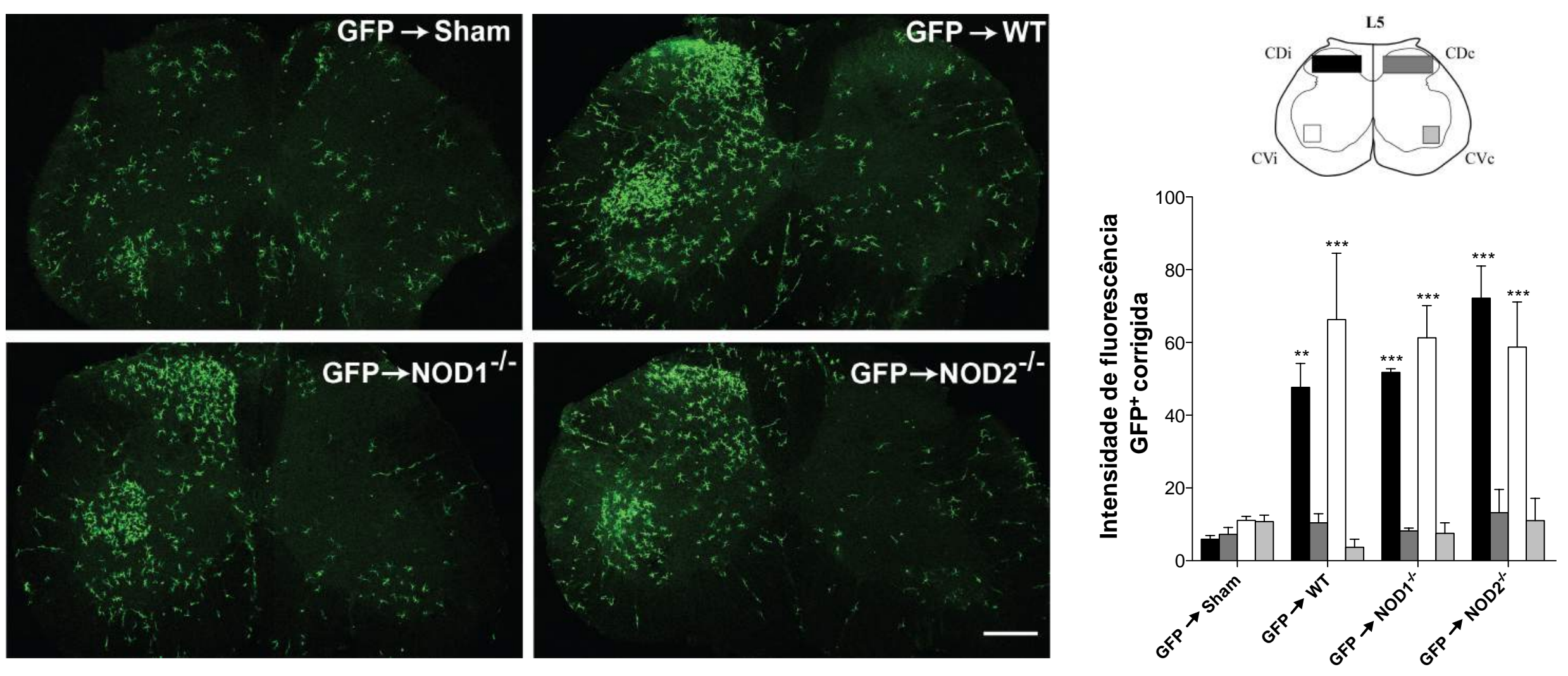

Figura 38. Infiltrado de células derivadas da medula óssea $\left(\mathrm{GFP}^{+}\right)$na medula espinal em animais quimeras de medula óssea, após indução de neuropatia periférica. Camundongos WT, $\mathrm{NOD}^{-/}$e NOD2 $2^{-/}$foram repovoados com células tronco provenientes da medula óssea de animais $\mathrm{GFP}^{+}$e submetidos a indução de neuropatia periférica. No dia 10 pós-cirurgia, as medulas espinais foram coletadas para análise por imunofluorêscencia. As imagens demonstram imunoreatividade para células GFP ${ }^{+}$(verde). A análise foi realizada por microscopia confocal. Barra de escala de $250 \mu \mathrm{m}$ (esquerda). A intensidade do sinal $\mathrm{GFP}^{+}$foi determinado como intensidade média em regiões especificas de interesse em secções da L5 e expressos como média \pm E.P.M. de 4 animais por grupo ${ }^{* *} \mathrm{p}<0,01 \mathrm{e} * * * \mathrm{p}<0,001$, ipsilateral vs. contralateral) (direita). 

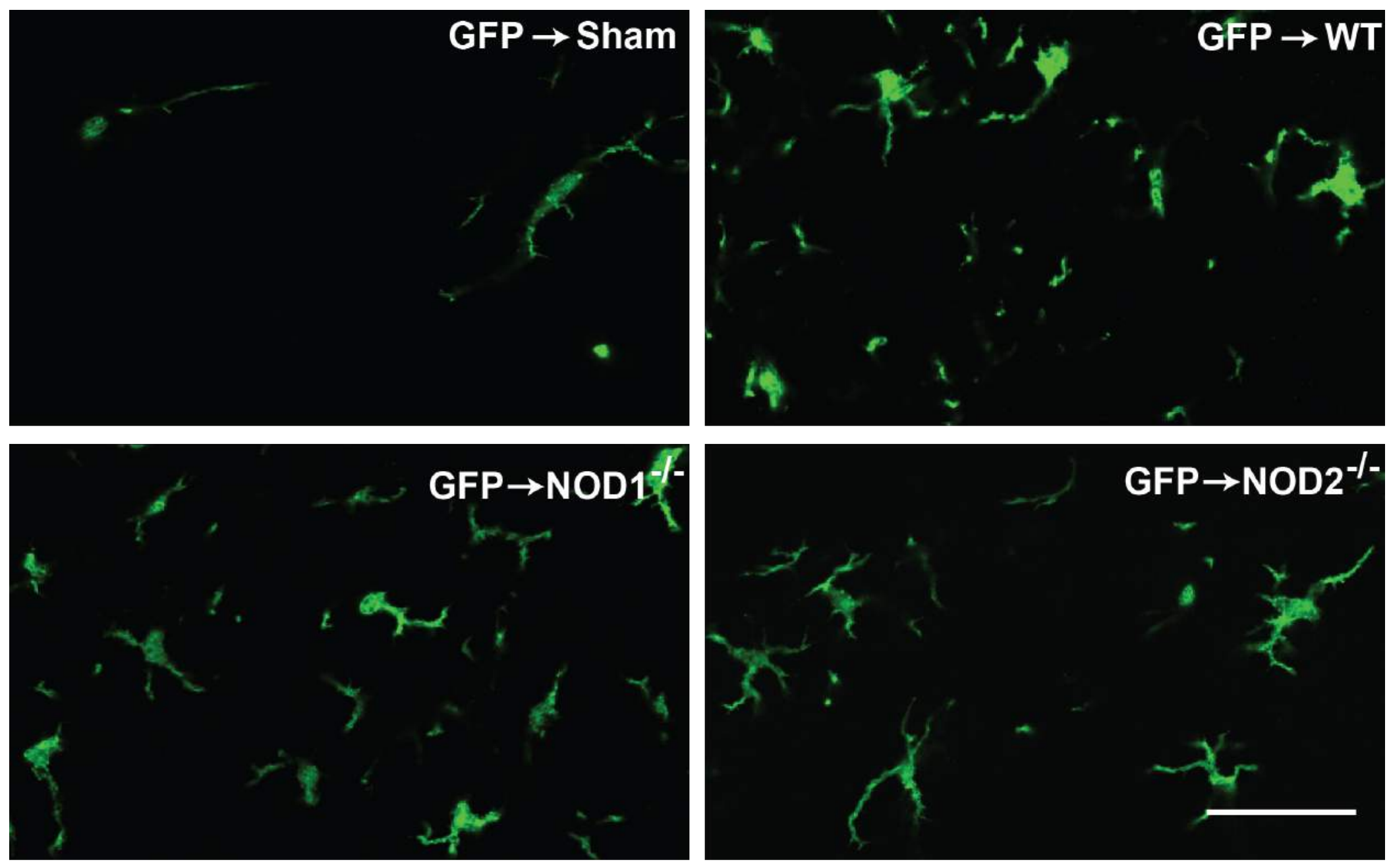

Figura 39. Infiltrado de células derivadas da medula óssea $\left(\mathrm{GFP}^{+}\right)$na medula espinal em animais quimeras de medula óssea, após indução de neuropatia periférica. As imagens demonstram uma ampliação de uma região do corno dorsal da medula espinal, apresentando imunoreatividade para GFP ${ }^{+}$(verde). A análise foi realizada por microscopia confocal. Barra de escala de $25 \mu \mathrm{m}$. 
As análises da ativação microglial forneceram evidências diretas que essas células $\mathrm{GFP}^{+}$presentes na medula espinal são micróglias, uma vez que células ramificadas expressando IBA-1 também foram observadas no corno dorsal e ventral ipsilateral da medula pós-neuropatia, mesmo padrão observado para células $\mathrm{GFP}^{+}$, sugerindo que além da ativação da micróglia residente na medula espinal, macrófagos derivados do sangue possuem a habilidade de infiltrar na medula, proliferar e diferenciar em micróglia ativada (Fig. 40).

Como já demonstrado nesse trabalho, após indução de neuropatia periférica, observou-se redução na expressão de IBA-1 no lado ipsilateral do corno dorsal e ventral nos animais $\mathrm{NOD}^{-/-}, \mathrm{NOD}^{-/-}$e RIPK2 ${ }^{-/-}$quando comparada ao grupo WT, sugerindo que a expressão de NOD1 e NOD2 é necessária para ativação da micróglia. Diferentemente desse padrão, os animais quimeras $\mathrm{NOD}^{-/-}$e $\mathrm{NOD}^{-/-}$ demonstraram um fenótipo de ativação microglial semelhante ao grupo WT (Fig. 41), sugerindo que as células periféricas que infiltram na medula espinal possam expressar NOD1 e NOD2. 

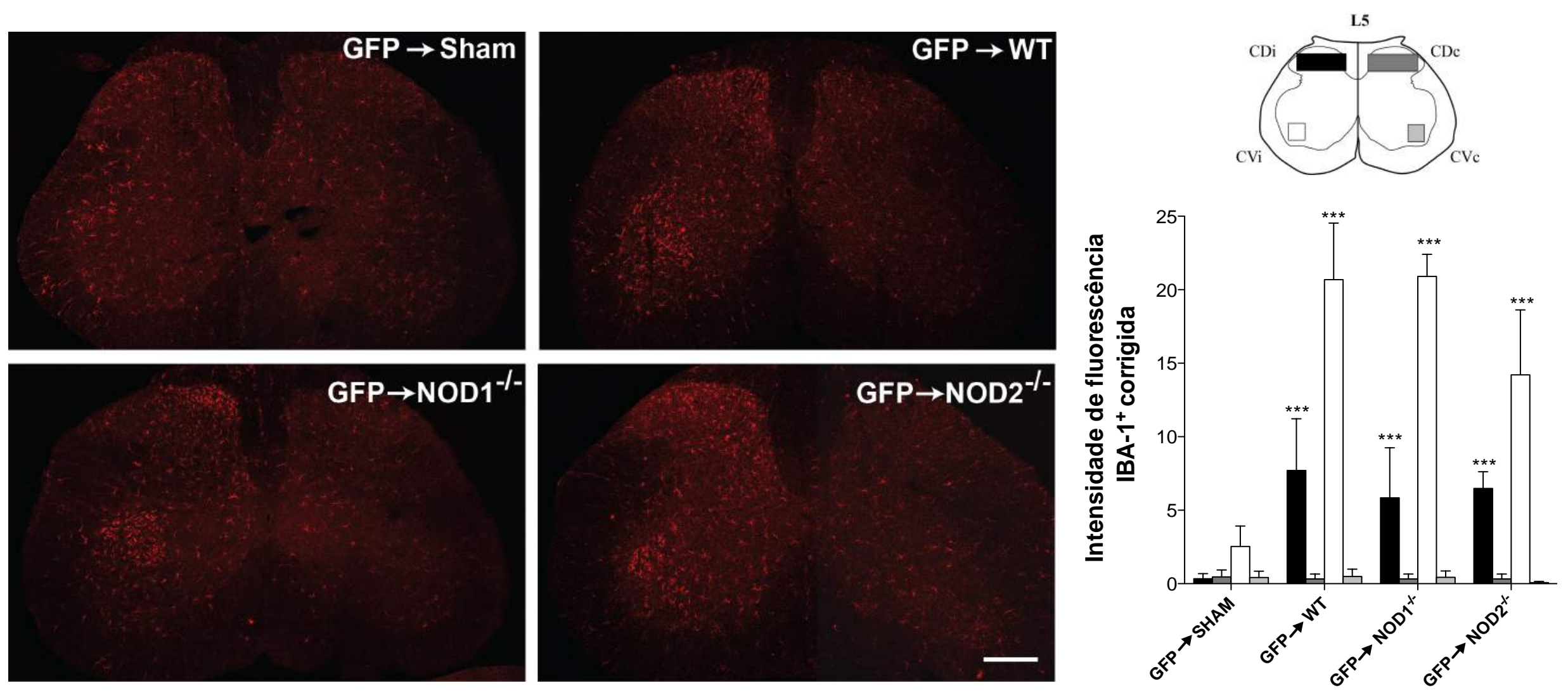

Figura 40. Ativação microglial (IBA-1) na medula espinal de animais quimeras de medula óssea, após indução de neuropatia periférica. Camundongos WT, NOD1 ${ }^{-/-}$ e NOD $2^{-/-}$foram repovoados com células tronco provenientes da medula óssea de animais $\mathrm{GFP}^{+}$e submetidos a indução de neuropatia periférica. No dia 10 pós-cirurgia, as medulas espinais foram coletadas para análise por imunofluorêscencia. As imagens demonstram imunoreatividade para micróglia, através do anticorpo IBA-1 (vermelho). A análise foi realizada por microscopia confocal. Barra de escala de $250 \mu$ m (esquerda). A intensidade do sinal IBA-1 foi determinado como intensidade média em regiões especificas de interesse em secções da L5 e expressos como média \pm E.P.M. de 4 animais por grupo (**p< 0,01 e ***p<0,001, ipsilateral vs. contralateral) (direita). 

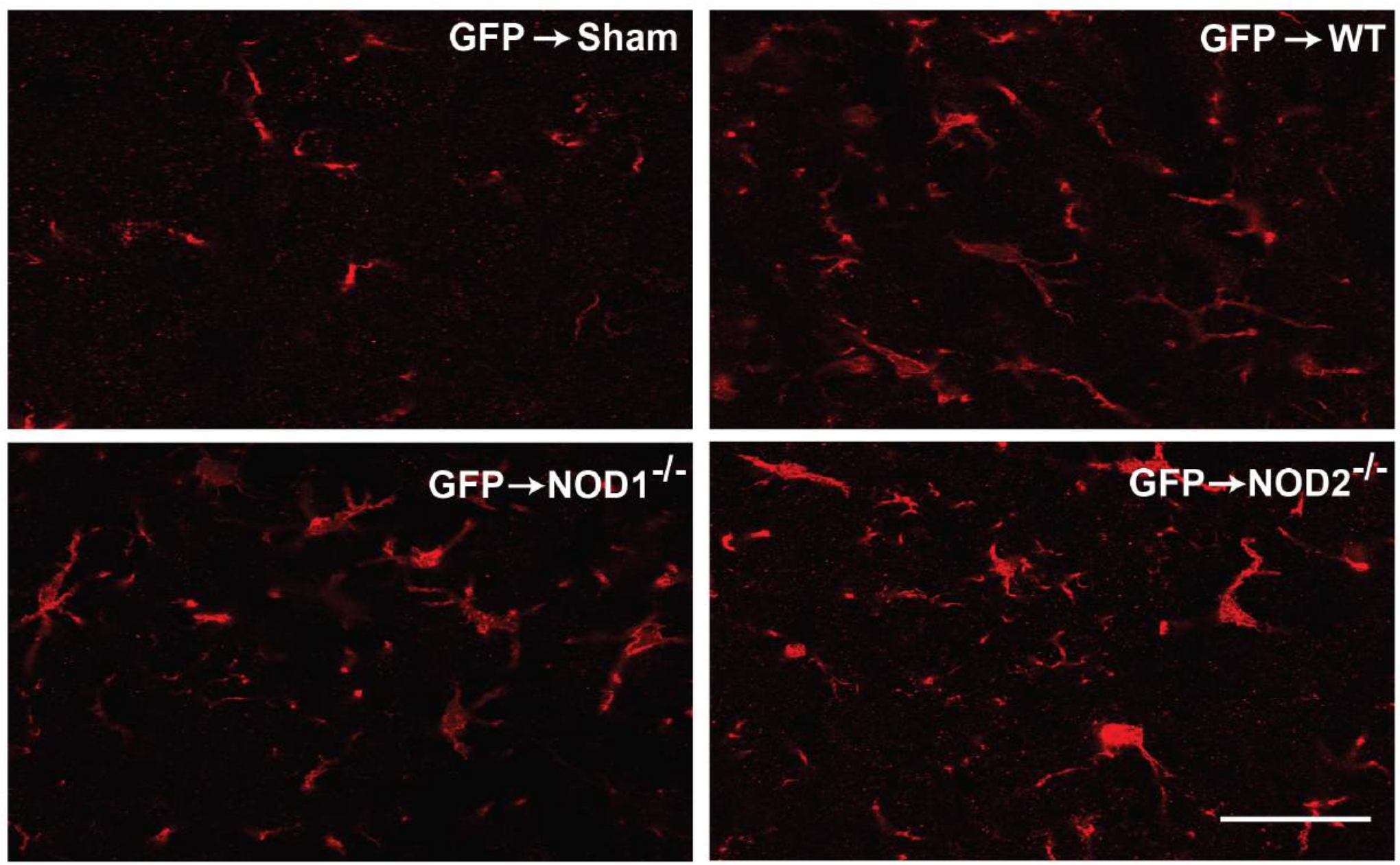

Figura 41. Ativação microglial (IBA-1) na medula espinal de animais quimeras de medula óssea, após indução de neuropatia periférica. As imagens demonstram uma ampliação de uma região do corno dorsal da medula espinal, apresentando imunoreatividade para micróglia, através do anticorpo IBA-1 (vermelho). A análise foi realizada por microscopia confocal. Barra de escala de $25 \mu \mathrm{m}$. 


\subsection{Papel do infiltrado de células periféricas derivada da medula óssea na hipersensibilidade nociceptiva mediada por NOD1 e NOD2 após indução de neuropatia periférica}

Como já demonstrado neste trabalho, após indução de neuropatia periférica, é observada uma redução significativa da hipersensibilidade mecânica nos animais $\mathrm{NOD}^{-/-}, \mathrm{NOD}^{-{ }^{-}}$e RIPK2 $2^{-/-}$quando comparada ao grupo WT.

Nosso próximo passo consistiu em avaliar o papel desse infiltrado de células imunes periféricas na hipersensibilidade nociceptiva mecânica mediada por NOD1 e NOD2 pós-neuropatia. Para isso, os seguintes grupos de animais quimeras foram gerados: 1) animais WT, $\mathrm{NOD}^{-/-}$e NOD2 $2^{-/-}$que receberam células da medula óssea de animais WT, 2) animais $\mathrm{NOD}^{-/}$que receberam células da medula óssea de animais $\mathrm{NOD}^{-/-}$e 3) animais NOD2 ${ }^{-/-}$que receberam células da medula óssea de animais $\mathrm{NOD}^{-/-}$.

Como resultado, foi observado que os animais quimeras WT transplantados com medula de animais WT induziram hipersensibilidade nociceptiva mecânica. Da mesma maneira, $\mathrm{NOD}^{-/-}$transplantados com medula de animais WT também produziram hipersensibilidade nociceptiva mecânica, do quinto ao décimo oitavo dia pós-neuropatia, quando comparado ao grupo $\mathrm{NOD}^{-/-}$transplantados com medula de $\mathrm{NOD}^{-/}$(Fig. 42A), sugerindo que para o receptor NOD1, a hipersensibilidade mecânica é dependente das células periféricas derivada da medula óssea.

Quando os animais NOD2 ${ }^{-/-}$foram transplantados com medula de animais WT, foi observada hipersensibilidade mecânica, um pouco mais atenuada, quando comparada a hipersensibilidade nociceptiva induzida nos animais quimeras WT transplantados com medula de animais WT (Fig. 42B), apesar de não haver diferença 


\subsection{Papel do infiltrado de células periféricas derivada da medula óssea na hipersensibilidade nociceptiva mediada por NOD1 e NOD2 após indução de neuropatia periférica}

Como já demonstrado neste trabalho, após indução de neuropatia periférica, é observada uma redução significativa da hipersensibilidade mecânica nos animais $\mathrm{NOD}^{-/-}, \mathrm{NOD}^{-{ }^{-}}$e RIPK2 $2^{-/-}$quando comparada ao grupo WT.

Nosso próximo passo consistiu em avaliar o papel desse infiltrado de células imunes periféricas na hipersensibilidade nociceptiva mecânica mediada por NOD1 e NOD2 pós-neuropatia. Para isso, os seguintes grupos de animais quimeras foram gerados: 1) animais WT, $\mathrm{NOD}^{-/-}$e NOD2 $2^{-/-}$que receberam células da medula óssea de animais WT, 2) animais $\mathrm{NOD}^{-/}$que receberam células da medula óssea de animais $\mathrm{NOD}^{-/-}$e 3) animais NOD2 ${ }^{-/-}$que receberam células da medula óssea de animais $\mathrm{NOD}^{-/-}$.

Como resultado, foi observado que os animais quimeras WT transplantados com medula de animais WT induziram hipersensibilidade nociceptiva mecânica. Da mesma maneira, $\mathrm{NOD}^{-/-}$transplantados com medula de animais WT também produziram hipersensibilidade nociceptiva mecânica, do quinto ao décimo oitavo dia pós-neuropatia, quando comparado ao grupo $\mathrm{NOD}^{-/-}$transplantados com medula de $\mathrm{NOD}^{-/}$(Fig. 42A), sugerindo que para o receptor NOD1, a hipersensibilidade mecânica é dependente das células periféricas derivada da medula óssea.

Quando os animais NOD2 ${ }^{-/-}$foram transplantados com medula de animais WT, foi observada hipersensibilidade mecânica, um pouco mais atenuada, quando comparada a hipersensibilidade nociceptiva induzida nos animais quimeras WT transplantados com medula de animais WT (Fig. 42B), apesar de não haver diferença 
estatística entre esses grupos. Esse resultado sugere que para o receptor NOD2, a hipersensibilidade mecânica também é dependente das células periféricas derivada da medula óssea.

A somatória dos dados corroboram a hipótese de que células periféricas que infiltram na medula espinal possam expressar NOD1 e NOD2 e portanto serem capazes de induzir hipersensibilidade mecânica e ativação microglial após a indução de neuropatia.

A

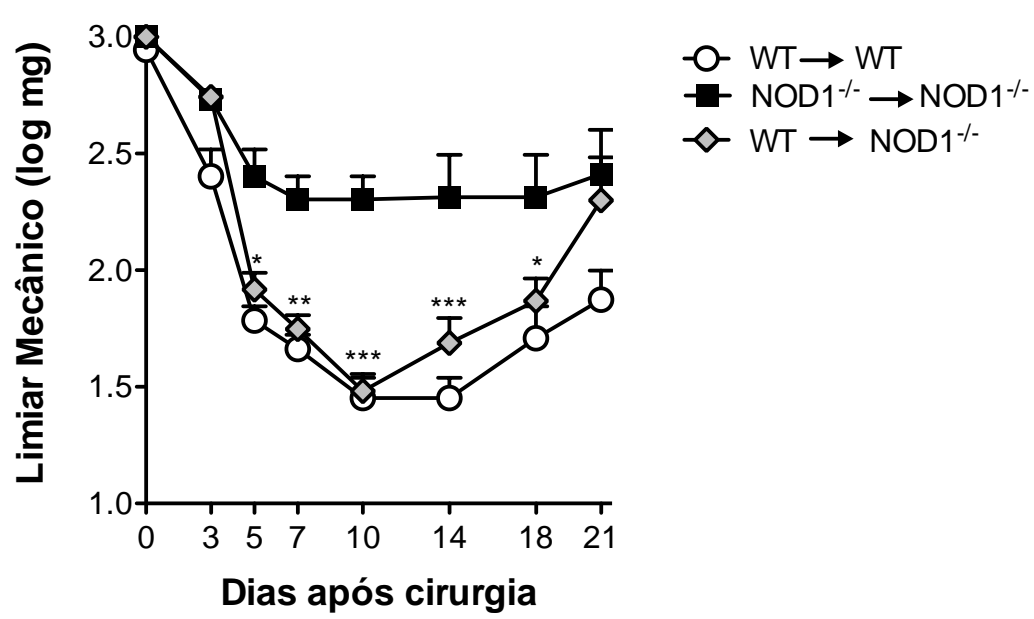

B

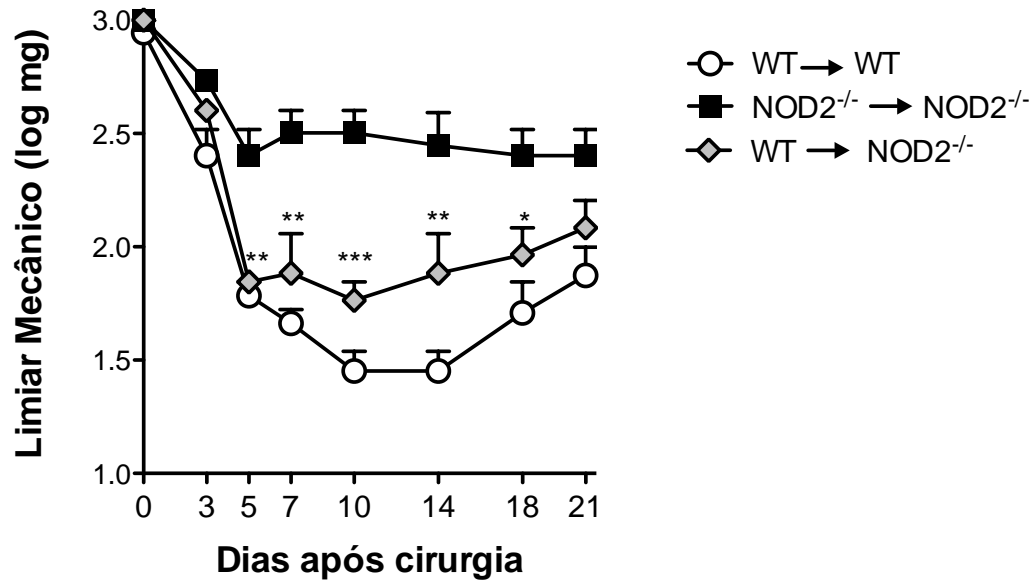

Figura 42. Papel do infiltrado de células periféricas derivada da medula óssea na hipersensibilidade nociceptiva mecânica mediada por NOD1 e NOD2, após indução de neuropatia periférica. Camundongos $\mathrm{WT}, \mathrm{NOD}^{-1-}$ (A) e $\mathrm{NOD}^{-1-}$ (B) foram repovoados com células tronco provenientes da medula óssea de animais WT, $\mathrm{NOD}^{-1-}$ e $\mathrm{NOD}^{-1-}$, submetidos a indução de SNI. A estimulação mecânica foi avaliada por filamentos de von Frey, durante um período de 21 dias. Os dados foram expressos como média \pm E.P.M. de 5 animais por grupo $\left({ }^{*} \mathrm{p}<0,05 ;{ }^{* *} \mathrm{p}<0,01 ;{ }^{* * *} \mathrm{p}\right.$ $<0,001$ quando comparada ao grupo de $\mathrm{NOD}^{-/} \rightarrow \mathrm{NOD}^{-/}$e $\mathrm{NOD}^{-/} \rightarrow \mathrm{NOD} 2^{-/}$. 
Discussão 


\section{Discussão}

Apesar de bastante explorado, os mecanismos celulares e moleculares subjacentes ao desenvolvimento e manutenção da dor crônica ainda permanecem obscuros. Acredita-se que a dor crônica resulta de plasticidade neuronal incluindo sensibilização periférica (sensibilização nos neurônios sensoriais primários) e sensibilização central (sensibilização na medula espinhal e outros neurônios do SNC) (Hokfelt et al., 1994; Woolf \& Salter, 2000; Luo \& Wang, 2009; Stucky et al., 2001).

Entretanto, esse fenômeno não é simplesmente caracterizado por alterações na atividade dos sistemas neuronais, mas envolve também a interação entre neurônios e principalmente interação neurônio-glia, visto que as células gliais da medula espinal desempenham papel importante na manutenção da sensibilização central e consequentemente, na perpetuação da dor crônica (Watkins et al., 2003; Woolf \& Mannion, 1999).

A ativação de células gliais na medula espinal tem sido fortemente relacionada ao desenvolvimento da dor neuropática após lesão nervosa periférica (Kim et al., 2007). Dessa maneira, diversos mecanismos têm sido propostos para explicar quais eventos moleculares desencadeiam a ativação dessas células e como os sinais resultantes dessa ativação contribuem para o processo neuropático. Dentre eles, nos últimos anos, grande destaque tem sido dado ao papel de alguns PRRs no processo de indução e manutenção da dor crônica neuropática (Raghavendra et al., 2004; Tanga et al., 2005), sugerindo que as vias da dor podem ser ativadas diretamente por detecção de PAMPs ou DAMPs.

Além disso, já foi demonstrado que em modelos de inflamação/infecção do SNC, os receptores TLRs e NLRs cooperam na ativação de micróglia (Guo et al., 
2006), o que nos levou a hipotetizar que os receptores NOD1 e NOD2 também possam desempenhar um papel importante no processo de dor crônica. Neste sentido, este trabalho avaliou de forma inédita os mecanismos envolvidos na possível participação de NOD1 e NOD2 no desenvolvimento da hipersensibilidade mecânica neuropática focando principalmente nos mecanismos espinais envolvidos.

Primeiramente, foi avaliada a expressão dos receptores NOD1 e NOD2 na medula espinal. Os resultados indicaram que NOD1 é induzido uma a duas semanas após a neuropatia, já a expressão de NOD2 apresenta níveis constitutivos baixos, não sendo alterado após desenvolvimento da neuropatia periférica. Esses dados podem explicar resultados prévios de nosso grupo de pesquisa, que demonstram que a injeção intratecal de MDP, mas não de iE-DAP, induz hipersensibilidade nociceptiva mecânica em camundongos selvagens (Ferreira et al., dados não publicados). Dessa maneira, sugere-se que NOD1 necessite de um processo patológico para ser ativado, como no caso da indução de neuropatia periférica. Já o receptor NOD2, apesar de expresso em níveis baixos na medula, é suficiente para desencadear uma resposta após estímulo com MDP.

Apesar de evidências na literatura da existência de receptores NOD1 e NOD2 em células da glia (Zheng et al., 2012; Sterka et al., 2006; Chauhan et al., 2009; Liu et al., 2010a, b), nossos resultados demonstraram que na medula espinal, após indução de neuropatia periférica, os receptores NOD1 estão expressos nos neurônios. Ainda, uma vez que os níveis de NOD2 na medula são relativamente baixos, a expressão desse receptor não foi detectada pela técnica de imunofluorescência.

No presente estudo, demonstramos o papel de NOD1 e NOD2 no desenvolvimento da dor neuropática. Os resultados mostraram que ambos os sexos dos animais $\mathrm{NOD}^{-/}$e $\mathrm{NOD}^{-/-}$apresentaram redução significativa da 
hipersensibilidade mecânica em comparação aos WT, após indução de neuropatia periférica, de maneira semelhante ao demonstrado por outros PRRs, como alguns TLRs. Tanga e colaboradores (2005) foram os primeiros a estabelecer o papel do receptor TLR4 em um modelo pré-clínico de dor neuropática. Utilizando camundongos deficientes ou mutantes de TLR4, e ratos tratados com TLR4 ODNantisense, eles demonstraram uma atenuação significativa na hipersensibilidade a dor após a transecção do nervo espinal nos animais. Similarmente, Kim e colaboradores (2007) mostraram que a hipersensibilidade nociceptiva mecânica pós-neuropatia é uma consequência direta da ativação de TLR2, uma vez que os animais deficientes para esse receptor suprimiram o desenvolvimento e manutenção da alodinia induzida após transecção do nervo espinal.

O envolvimento de NOD1 e NOD2 no desenvolvimento da dor crônica inflamatória também foi avaliado. Como resultado, foi observado que tanto os animais WT como $\mathrm{NOD}^{-/}$e $\mathrm{NOD}^{-/-}$, administrados com CFA intraplantar, apresentaram uma hipersensibilidade mecânica observada durante os 21 dias avaliados, demonstrando que esses receptores não estão envolvidos nesse processo. Similarmente, em outro estudo, foi demonstrado que ratos submetidos à injeção intraplantar de CFA e tratados com inibidor de TLR4 (TAK-242), apresentaram hipersensibilidade mecânica semelhante aos animais sem tratamento com inibidor de TLR4. (Sauer et al., 2014).

Uma vez demonstrando que NOD1 e NOD2 participam somente do processo de indução e manutenção da dor neuropática, o próximo passo consistiu em avaliar o envolvimento desses receptores na ativação de células da glia na medula espinal durante o processo neuropático. Dessa maneira, os resultados demonstraram por diferentes técnicas que os animais $\mathrm{NOD}^{-/-}$e $\mathrm{NOD}^{-/-}$apresentaram uma redução 
significativa na ativação de micróglia e astrócitos após a indução de neuropatia periférica, sugerindo que ambos os receptores contribuem para a ativação glial no decorrer do processo neuropático. Esses resultados estão de acordo com trabalhos que demonstram a participação de TLR4 e TLR2 na ativação glial espinal após indução de neuropatia periférica.

Tanga e colaboradores (2005) demonstraram que animais TLR $4^{-/-}$apresentam, associado a redução na dor crônica neuropática, uma diminuição na ativação astrocitária e microglial, além de redução da expressão gênica de IL-1 $\beta$, IL-6 e TNFa. Da mesma maneira, Kim e colaboradores (2007) mostraram que neurônios sensitivos danificadas podem ativar células gliais in vitro, via TLR2, e que, a hipersensibilidade a dor e o aumento na expressão de citocinas pró-inflamatórias são consequências diretas da ativação desses receptores durante o processo neuropático, uma vez que todas essas características foram reduzidas em camundongos TLR2 ${ }^{-/}$.

Diversos trabalhos na literatura sugerem que a inflamação periférica aguda e a lesão de nervos periféricos produzem reações neuroinflamatórias distintas na medula espinal (Sweitzer et al., 1999). Dessa maneira, o envolvimento das células da glia é um processo convincente na dor neuropática, enquanto em modelos de dor inflamatória ainda seja questionável.

Foi demonstrado que a administração intraplantar de formalina ou zimozan produz branda ativação microglial na medula espinal em contraste com uma robusta ativação após indução de neuropatia periférica (Sweitzer et al., 1999). Lee e colaboradores (2010), utilizando modelo de dor orofacial, demostraram que os estímulos de lesão nervosa periférica, infecção e inflamação são capazes de induzir ativação glial no SNC, mas em padrões completamente diferentes, sendo observada forte ativação glial somente através da lesão nervosa que cursa com neuropatia. Além 
disso, outros trabalhos demonstram ausência de ativação glial após indução de inflamação periférica (Clarke et al., 2007; Lin et al., 2007). Essa discrepância de resultados aponta notável variabilidade da ativação de células gliais em resposta a diferentes estímulos. Uma vez que a participação da ativação glial na dor inflamatória é relativamente branda ou as vezes inexistente, podemos sugerir que os receptores NOD1 e NOD2 atuam somente no processo de dor neuropática periférica por envolverem ativação de células gliais.

Dando sequência, a ativação glial pode reforçar a transmissão neuronal da informação nociceptiva. Um possível mecanismo para que a ativação dessas células induza hipersensibilidade nociceptiva consiste na liberação de proteínas imunes clássicas, incluindo citocinas pró-inflamatórias, como a IL-1 $\beta$, IL-6 e TNF- $\alpha$, tanto perifericamente como no SNC, implicadas na modulação da sensitividade da dor (Raghavendra \& DeLeo, 2003).

Nesse contexto, observamos uma redução significativa na produção de IL-1ß e TNF- $\alpha$ na medula espinal de animais $\mathrm{NOD}^{-/-}$e NOD2 ${ }^{-/-}$, quando comparadas com o animais WT submetidos à lesão nervosa, sugerindo envolvimento desses receptores na liberação de citocinas pró-nociceptivas após indução de neuropatia periférica.

A ativação dos receptores PRRs na dor neuropática, por sua vez, vem sendo bastante estudada. Nesse sentido, DAMPs endógenos são hipotetizados como mediadores da sinalização imune central pela ligação com TLRs. Adicionalmente, ligantes exógenos têm sido administrados diretamente na medula espinal em diferentes estudos para avaliar o papel de TLRs no processo doloroso (Reeve et al., 2000; Clark et al., 2006; Saito et al., 2010).

Reeve e colaboradores (2000) demonstraram que a administração de LPS pela via intratecal induz hipersensibilidade mecânica através do aumento da atividade de 
neurônios do corno dorsal da medula e aumento na produção de citocinas próinflamatórias, as quais são produzidos predominantemente por células da glia (Clark et al., 2006). Além disso, foi demonstrado que essa hipersensibilidade mecânica induzida por LPS é atenuada pelo pré-tratamento com inibidores gliais (pentoxifilina e minociclina) (Saito et al., 2010).

Utilizando dessa mesma ferramenta para avaliar o papel indireto de NOD2 na indução de dor, resultados recentes de nosso grupo de pesquisa demonstraram que a injeção intratecal de MDP leva a aumento na expressão do RNAm de IL-1 $\beta$, IL-6 e TNF- $\alpha$ na medula espinal. Também, o pré-tratamento de camundongos selvagens com propentofilina, minociclina, fluorocitrato reduziu o desenvolvimento da hipersensibilidade mecânica induzida por MDP (Ferreira et al., dados não publicados). Esses dados corroboram nossa hipótese de que a ativação de NOD1 e NOD2 induz hipersensibilidade nociceptiva via indução de mediadores próinflamatórios produzidos pela ativação de células gliais.

Dando sequência, outro ponto explorado neste trabalho foi a estimulação in vitro de células microgliais por ligantes de NOD1, NOD2 e TLR4 ou pela administração conjunta de agonistas de NLRs e TLRs. Dessa maneira, foi observado que o MDP sozinho é incapaz de gerar uma resposta e que o LPS na concentração de 0,1ng/mL gera uma indução branda na liberação das citocinas. Porém, a administração conjunta de ambos (MDP+LPS) foi capaz de produzir uma robusta resposta caracterizada pela elevada produção de citocinas pró-inflamatórias, o que não foi observado quando essas culturas de micróglia foram derivadas de animais NOD2 ${ }^{-1}$. Esses resultados corroboram dados já existentes na literatura.

Sterka e Marriott (2006) demonstraram que culturas primárias de micróglia expressam níveis constitutivos de NOD2 e que essa expressão é aumentada após 
exposição a bactérias gram-negativas e ligantes específicos dos receptores TLR4 (LPS) e TLR5 (flagelina). Ainda, diversos trabalhos têm demonstrado o efeito potencial de MDP com agonistas de TLRs na micróglia, desencadeando uma elevada resposta inflamatória, incluindo um aumento na liberação das citocinas próinflamatórias e produção de óxido nítrico (NO) (Chauhan et al, 2009; Sterka e Marriott, 2006; Kinser et al, 2006, Ribes et al., 2006).

Embora essa potencialização possa ser explicado por vários mecanismos, a interpretação mais simples sugere que a ligação de LPS ao TLR4 eleva a expressão de NOD2, que pode então associar-se na presença de MDP, para desencadear a ativação de NF-kB e produção de citocinas inflamatórias com muito mais eficiência do que somente a ativação de TLR4 sozinho (Sterka e Marriott, 2006). Do mesmo modo, devido a expressão relativamente baixa de NOD2 na ausência de ligantes de TLR, MDP sozinho teria uma ação menos eficaz. Outro trabalho aponta uma possível ligação entre TLRs, NOD2 e mecanismos purinérgicos de inflamação no SNC. Os autores sugerem que a potencialização mediada por ligantes de TLRs e MDP promove ativação microglial, induzindo efeitos aditivos na produção de NO, TNF- $\alpha$ e aumentando a expressão de P2X4 (Guo et al., 2006). Além disso, Chauhan e colaboradores (2009) demonstraram que o MDP, quando administrado de maneira conjunta com LPS ou flagelina, não induz aumento na produção de citocinas próinflamatórias em culturas de micróglia derivada de animais $\mathrm{NOD}^{-/-}$, confirmando assim a ação específica do MDP nos receptores NOD2.

Por outro lado, Sterka e Marriott (2006) demonstraram que culturas primárias de micróglia expressam baixíssimos ou as vezes não expressam níveis constitutivos de NOD1 e apenas modestos níveis após exposição a bactérias. Neste trabalho, foi observado que o iE-DAP sozinho é incapaz de gerar uma resposta e que a 
administração conjunta com LPS, também não foi capaz de aumentar os níveis das citocinas pró-inflamatórias liberadas. Diferentemente, essa potencialização de efeito é observada em outros tipos de cultura, como de macrófagos (Chamaillard et al., 2003) e células mononucleares do sangue periférico (Van Heel et al., 2005). Além disso, Zheng e colaboradores (2012) demostraram que o LPS pode ativar culturas de micróglia e induzir a produção de citocinas pró-inflamatórias agindo por duas vias. A primeira seria dependente de TLR4 e das MAPKs do tipo quinase c-Jun N-terminal (JNK), já a segunda via seria dependente de NOD1 e NF-кB.

Recentemente, a co-ativação in vivo dos receptores NODs e TLRs foi investigada. Farzi e colaboradores (2015) mostraram que a injeção intraperitoneal de FK565 (agonista NOD1) e MDP agravou e prolongou o comportamento doentio induzido por LPS, diferentemente de quando esses agonistas NODs foram administrados sozinhos. Além disso, a exacerbação do comportamento doentio, induzida por FK565 ou MDP em combinação com LPS, foi acompanhada por uma elevação nos níveis de proteínas plasmáticas, citocinas pró-inflamatórias cerebrais (IL-1 $\beta$, IL-6 e TNF- $\alpha$ ) e um aumento na ativação dos núcleos cerebrais relevantes na doença.

Sabe-se que a estimulação dos receptores NOD1 e NOD2, por estímulos microbianos ou endógenos, resulta na ativação de NF-kB, por meio da via de sinalização dependente de RIPK2, levando a indução de respostas pró-inflamatórias (Akira et al., 2006; Inohara et al., 1999; Ogura et al., 2001). A importância da molécula adaptadora RIPK2 na ativação de NF-kB e consequente transcrição de citocinas pró-inflamatórias foi demonstrada, uma vez que células provenientes de

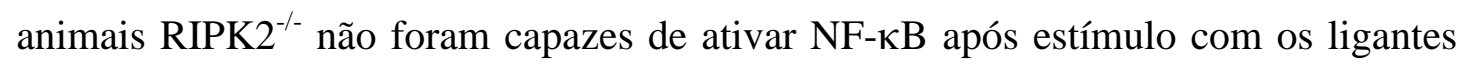
de NOD1 ou NOD2 (Kobayashi et al., 2002). Além disso, macrófagos NOD2 ${ }^{-/-}$e 
$\mathrm{RIPK}^{-/-}$, estimulados com MDP, apresentam comprometimento da resposta, assim como redução da produção de citocinas dependentes de NF-kB e MAPKs (Park et. al, 2007). Ainda, a ativação de NF-kB induzida por NOD2 correlaciona-se com sua capacidade de interagir com RIPK2 e é especificamente inibida por uma forma truncada de RIPK2, mutante desta proteína (Ogura et al., 2001b).

Mais recentemente, inibidores de RIPK2 se mostraram eficientes em reduzir a inflamação em dois modelos in vivo de doenças inflamatórias. Primeiramente, em um modelo de peritonite induzida por MDP, esses compostos inibiram significativamente o recrutamento celular inflamatório quando comparado aos animais tratados com veículo. Em outro modelo de ileíte semelhante à Doença de Crohn, a inibição farmacológica de RIPK2 reduziu a secreção de citocinas pró-inflamatórias em macrófagos e se correlacionou com uma melhora da doença (Tigno-Aranjuez et al., 2014). Portanto, todos esses trabalhos corroboram a importância da sinalização de NOD1 e NOD2, via RIPK2, na indução de respostas pró-inflamatórias.

Uma vez que os resultados deste trabalho apontam que os receptores NOD1 e NOD2 contribuem para a gênese da dor neuropática, investigamos também o papel da quinase RIPK2, recrutada após a ativação desses receptores, nesse processo. Dessa maneira, a somatória dos resultados obtidos apontaram para a contribuição da via de sinalização dependente de RIPK2 na hipersensibilidade nociceptiva mecânica, indução de citocinas pró-inflamatórias e ativação das células gliais na medula espinal. Com base nos dados e estudos acima descritos, sugere-se que a ativação dos receptores NOD1 e NOD2 e, consequente, recrutamento da proteína adaptadora RIPK2, compreenda uma etapa importante para o desenvolvimento e manutenção da dor crônica neuropática.

O decurso temporal de ativação das células gliais bem como o aumento na 
expressão de citocinas pró-inflamatórias estão intimamente relacionado ao desenvolvimento da dor neuropática (Raghavendra et al., 2004). Além disso, após a lesão de um nervo periférico, a micróglia ativada leva a expressão do receptor P2X4. Foi demonstrado que a hipersensibilidade nociceptiva induzida pós-neuropatia é mediada pelos receptores P2X4 na medula espinal (Tsuda et al., 2003) através da liberação do BDNF, responsável por causar uma desinibição dos neurônios do corno dorsal da medula e consequentemente hiperexcitabilidade neuronal, fundamental para o desenvolvimento da dor neuropática (Coull et al., 2005). Ainda, a co-estimulação de culturas primárias de micróglias com MDP e LPS ou Pam3CSK4 (agonista TLR1/2) induziu um aumento na expressão de P2X4 microglial e consequentemente na liberação de citocinas pró-inflamatórias (Guo et al., 2006).

Neste trabalho, nós observamos que no pico de expressão de P2X4 nos animais WT, ou seja, no décimo quarto dia pós-neuropatia, os animais $\mathrm{NOD}^{-/}$, $\mathrm{NOD}^{-/-}$e RIPK2 ${ }^{-/-}$apresentaram uma redução na expressão desse receptor de ATP, apontando um possível mecanismo para explicar a participação de NOD1 e NOD2, via RIPK2, no processo de neuropatia periférica.

Nos últimos anos, uma grande diversidade de estudos apontam que a patogênese da dor neuropática envolve uma neuroinflamação mediada pela interação entre células imunes e neurônios (Ren \& Dubner, 2010; Calvo et al., 2012). Sendo assim, em resposta a uma lesão periférica de nervos, células imunes periféricas, tais como macrófagos, neutrófilos, linfócitos T e mastócitos, infiltram-se no nervo lesado e tornam-se ativadas. Mediadores inflamatórios liberados por essas células imunes podem induzir a sensibilização dos nociceptores e aumentar a excitabilidade do neurônios aferentes primários nociceptivos (Scholz \& Woolf, 2007). Na medula espinal, as células gliais recebem sinais a partir dos neurônios periféricos lesados e 
tornam-se ativadas, causando assim facilitação sináptica e induzindo um aumento na responsividade dos neurônios nociceptivos do corno dorsal da medula espinal (Gao \& Ji, 2010). Adicionalmente, trabalhos apontam que a neuropatia periférica é capaz de induzir infiltração de células imunes periféricas para a medula espinal, o que pode contribuir também para a patogênese da dor neuropática (Sweitzer et al., 2002; Hu et al., 2007; Cao \& DeLeo, 2008; Costigan et al., 2009).

Um ponto importante bastante discutido na literatura consiste na origem dessas células microgliais ativadas na medula espinal e a possibilidade de haver uma subpopulação específica envolvida na dor. Sabe-se que o SNC é caracterizado por duas principais populações relacionadas aos monócitos: micróglia residente e macrófagos perivasculares hematopoiéticas (Raivich \& Banati, 2004).

A renovação da micróglia na idade adulta ocorre não só através da proliferação das células pré-existentes, mas também através do recrutamento de precursores que derivam da medula óssea, uma vez que os macrófagos perivasculares são reabastecidos por monócitos circulantes que migram através da membrana basal para o parênquima do SNC, processo reforçado em diferentes formas de neuropatologias inflamatórias (Streit et al., 1989; Lawson et al., 1992; Priller et al., 2001; Sweitzer et al., 2002).

O recrutamento de leucócitos circulantes para o SNC, em condições fisiológicas normais ou em estados patológicos, apoia as funções essenciais de vigilância e defesa do hospedeiro. Embora os mecanismos e sinais moleculares responsáveis pela migração de células periféricas inflamatórias para compartimentos específicos do SNC não estarem completamente identificados, fortes evidências apontam que quimiocinas e moléculas de adesão são essenciais para esse processo (Charo \& Ransohoff, 2006). 
A contribuição relativa da micróglia residente e da derivada da medula óssea no processo patológico pode variar dependendo do grau e da severidade da lesão, como é evidenciado pela diferença no acúmulo de precursores que derivam da medula óssea (Furuya et al, 2003; Priller et al., 2006; Solomon et al., 2006; Denker et al., 2007). Portanto, uma compreensão do distinto papel dessas células de linhagem monocíticas na dor neuropática induzida por lesão periférica é importante para direcionar a busca por novos alvos terapêuticos (Zhang et al., 2007).

Dessa maneira, o último ponto explorado neste trabalho foi avaliar a contribuição das células imunes periféricas no processo neuropático induzido por NOD1 e NOD2, uma vez que já foi descrita a elevada expressão desses receptores nas células hematopoiéticas (Ogura et al., 2001b). Para isso, foram gerados camundongos quimeras de medula óssea, nos quais a medula óssea de animais WT, NOD1 ${ }^{-1-}$ e $\mathrm{NOD}^{-/-}$foi transplantada a partir de animais que expressam GFP.

Nós demonstramos que células periféricas derivadas da medula óssea podem se infiltrar no parênquima espinal após indução de neuropatia periférica, uma vez que células ramificadas $\mathrm{GFP}^{+}$foram observadas no corno dorsal e ventral ipsilateral da medula espinal tanto de animais WT como também $\mathrm{NOD}^{-/-}$e $\mathrm{NOD} 2^{-/-}$, quando comparadas ao lado contralateral.

Para identificar o fenótipo dessas células infiltradas $\mathrm{GFP}^{+}$, foi utilizado um anticorpo diretamente contra IBA-1 para marcar micróglia. As análises forneceram evidências diretas que essas células $\mathrm{GFP}^{+}$presentes na medula espinal são micróglias, uma vez que células ramificadas expressando IBA-1 também foram observadas no corno dorsal e ventral ipsilateral da medula pós-neuropatia, mesmo padrão observado para células GFP ${ }^{+}$

Corroborando com esses dados, Zhang e colaboradores (2007) demostraram 
que células $\mathrm{GFP}^{+}$presentes no parênquima medular, após indução de neuropatia periférica, não se colocalizaram com marcadores de neurônios, astrócitos, oligodendrócitos e células endoteliais, mas somente com micróglia. Além disso, foi demonstrado por marcação com bromodeoxiuridina (BrdU) que ambas células residentes e provenientes da medula óssea possuem a capacidade de se dividir, sendo que em torno de $20 \%$ das células em proliferação são derivadas de macrófagos periféricos, do terceiro ao décimo quarto dia pós-neuropatia.

Como já demonstrado neste trabalho, a ativação microglial observada nos animais selvagens é drasticamente reduzida nos animais NOD $1^{-/-}$e NOD2 $2^{-/}$sugerindo que a expressão de NOD1 e NOD2 é necessária para ativação da micróglia. Diferentemente desse padrão, os animais quimeras $\mathrm{NOD}^{-/-}$e NOD2 ${ }^{-{ }^{--}}$, repovoados com medula óssea de animais $\mathrm{GFP}^{+}$, passaram a apresentar um fenótipo de ativação microglial semelhante ao grupo WT. Esses resultados sugerem que a simples presença de NOD1 e NOD2 nas células imunes periféricas já é suficiente para contribuir para a microgliose espinal pós-neuropatia. Ainda, apesar de demonstrada a presença de NOD1 nos neurônios da medula espinal, sugere-se que a importância desse receptor no processo neuropático consiste na sua presença em células periféricas após a indução de neuropatia.

Para finalizar, avaliamos o papel desse infiltrado de células imunes periféricas na hipersensibilidade nociceptiva mecânica mediada por NOD1 e NOD2 pósneuropatia. Como já mostrado no trabalho, a hipersensibilidade mecânica observada nos animais selvagens é altamente reduzida nos animais $\mathrm{NOD}^{-/-}$e $\mathrm{NOD}^{-/-}$, apontando que esses receptores contribuem para a gênese da dor neuropática. Diferentemente desse padrão, os animais quimeras $\mathrm{NOD}^{-/-}$e NOD2 ${ }^{-/-}$, repovoados com medula óssea de animais $\mathrm{GFP}^{+}$, passaram a apresentar um fenótipo de 
hipersensibilidade mecânica semelhante ao grupo WT, sugerindo que a hipersensibilidade nociceptiva mecânica mediada por NOD1 e NOD2 é dependente das células periféricas derivada da medula óssea.

Dessa maneira, a somatória desses resultados corroboram a hipótese que células periféricas que expressam NOD1 e NOD2 podem se infiltrar na medula espinal e portanto serem capazes de induzir hipersensibilidade mecânica e ativação microglial após a indução de neuropatia.

Além disso, sabe-se que as células não-neuronais presentes no gânglio da raiz dorsal (GRD) também têm sido implicadas no desenvolvimento da dor neuropática. Após a lesão de nervo periférico, células de Schwann são ativadas e produzem citocinas pró-inflamatórias (Wagner \& Myers, 1996; Temporin et al., 2008). Também, após esse processo, células imunes periféricas são ativadas e podem se infiltrar nos GRDs (Hu \& McLachlan, 2002; Morin et al., 2007; Patro et al., 2010), induzindo a expressão de citocinas pró-inflamatórias, quimiocinas e ativação de células satélites, contribuindo assim para sensibilização e excitabilidade dos neurônios aferentes primários nociceptivos (Scholz \& Woolf, 2007).

Uma hipótese plausível seria que os receptores NOD1 e NOD2 possam ser expressos em células gliais que residem no GRD, como por exemplo, as células satélites. Estas, após ativação, poderiam liberar mediadores pró-nociceptivos nos neurônios aferentes primários, e assim ter um efeito direto na hipersensibilidade nociceptiva, indução de citocinas pró-inflamatórias e ativação das células gliais na medula espinal, após indução de neuropatia periférica.

Uma vez elucidados os possíveis mecanismos pelos quais os receptores NOD1 e NOD2 possam contribuir para o desenvolvimento do processo neuropático, sugerese que a ativação desses receptores, por algum DAMP liberado em reposta a uma 
lesão nervosa, resulte na ativação de vias de sinalizações e produção de mediadores pró-nociceptivos similares à ativação pelo reconhecimento de PAMPs.

Resultados ainda preliminares apontam que a estimulação de culturas de micróglia com sobrenadante de neurônios sensoriais danificados (SNSD) é capaz de induzir a expressão de genes pró-inflamatórios. Ao contrário, quando culturas de micróglia de animais NOD2 $2^{-/}$são estimuladas com SNSD uma redução na expressão de TNF- $\alpha$ foi observada, demonstrando que o efeito de SNSD na micróglia é mediado por NOD2 (dados não mostrados). Estudos são necessários para determinar a identidade da(s) molécula(s) derivada de SNSD que ativam as células microgliais via NOD2.

Diversos trabalhos têm demonstrado que alguns TLRs implicados na dor neuropática podem ser ativados por DAMPs liberados por neurônios sensoriais danificados durante o processo neuropático, incluindo fibronectina, HMGB1 e proteínas de choque térmico (HSPs) (Nicotra et al., 2012; Grace et al., 2014).

Após lesão nervosa periférica, HSPs são liberadas e podem ativar células da glia diretamente ou indiretamente por promover a liberação de substâncias neuronais (van Noort, 2008). Foi demonstrado que HSP60 e HSP90 podem induzir a liberação de TNF- $\alpha$ de células imunes e células gliais por um mecanismo dependente de TLR2 e TLR4 (van Noort, 2008; Hutchinson et al., 2009). Também foi demonstrado que após a indução de neuropatia periférica, HSP60 é altamente expressa na medula espinal. Além disso, a inibição de HSP90 é capaz de reverter o processo neuropático instalado (Hutchinson et al., 2009; Zou et al., 2012). Esses resultados apontam que HSPs desencadeiam através de TLRs, ativação glial e um processo pró-inflamatório que contribui no quadro de dor neuropática.

Dessa maneira, uma vez já descrito que ambos receptores NOD1 e NOD2 
também reconhecem HSP90 e HSP70 (Hans, 2005; Mohanan e Grimes, 2014; Mayor et al., 2007; Lee et 2012), estas poderiam ser possíveis moléculas endógenas, liberadas após lesão nervosa periférica, responsáveis pela ativação de NOD1 e NOD2. Estudos são necessários para comprovar essa hipótese.

Somando todos os resultados obtidos, sugere-se que a ativação de receptores NOD1 e NOD2, presentes na medula espinal e possivelmente do GRD, através da via de sinalização dependente de RIPK2, possa desempenhar um importante papel na dor neuropática. A hipótese é que esses receptores possam ser expressos em células imunes periféricas, que se infiltram no GRD ou na medula espinal, ou também em células gliais satélites no GRD (Ilustração 3). Dessa maneira, nossos resultados apontam para NOD1 e NOD2 como um possível alvo para o desenvolvimento de novas drogas para o tratamento da dor neuropática.

Atualmente, diversos grupos de pesquisa têm objetivado o desenvolvimento de pequenas moléculas capazes de modular a sinalização de NOD1 e NOD2 (Geddes et al., 2009; Jakopin, 2014; Maisonneuve et al., 2014). Moléculas capazes de reforçar ou bloquear a sinalização de NOD1 e NOD2 teriam aplicações em diversas patologias além da dor neuropática, como por exemplo doenças inflamatórias, tais como doença de Crohn, sarcoidose, asma e artrite.

Uma das primeiras abordagens bem sucedidas da utilização dessas moléculas veio com o desenvolvimento de inibidores de quinase capazes de bloquear RIPK2 (Tigno-Aranjuez et al., 2010; Jun et al., 2013; Tigno-Aranjuez et al., 2014). Porém, na maioria dos casos, os mecanismos moleculares pelos quais essas moléculas atuam ainda permanecem pouco compreendidos.

Dessa maneira, a modulação da sinalização de NOD1 e NOD2 pode ser considerada como uma estratégia terapêutica no tratamento de diferentes patologias. 
No entanto, estudos adicionais são necessários para determinar o custo-benefício de ter como alvos esses receptores, com o objetivo de balancear por um lado a redução da ativação glial e por outro a possível supressão imune e susceptibilidade a infecções. 


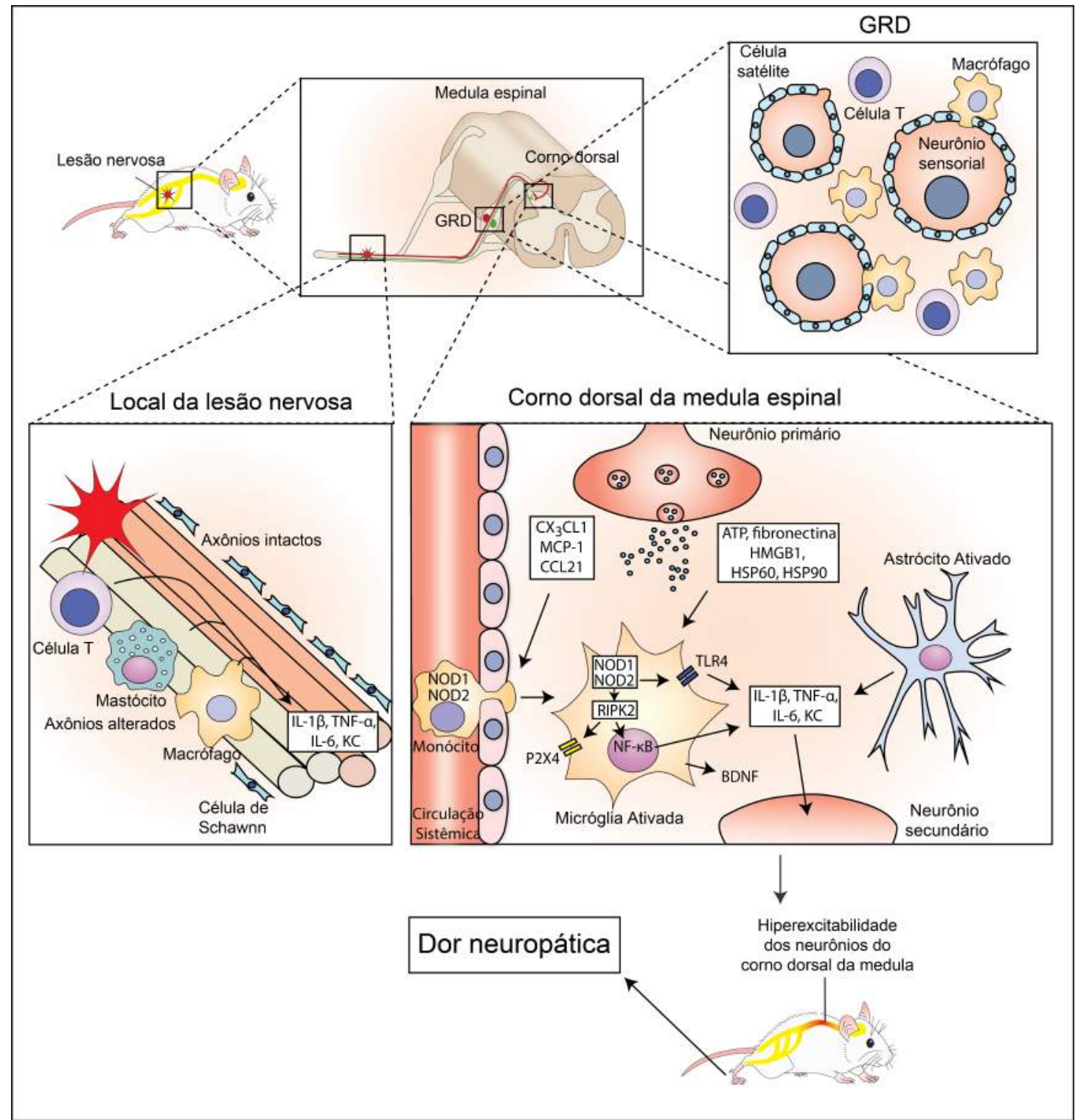

Ilustração 3. Modelo esquemático do possível mecanismo pelo qual NOD1 e NOD2 contribuem para a gênese da dor neuropática. Em resposta a uma lesão periférica de nervos, células imunes periféricas, tais como macrófagos, neutrófilos, linfócitos T e mastócitos, infiltram-se no nervo lesado, tornam-se ativadas e liberam mediadores inflamatórios. As células de Schwann começam a proliferar, diferenciar e a iniciar a degeneração valeriana no intuito de posterior regeneração do nervo. No GRD, o número de macrófagos e linfócitos T aumentam acentuadamente após a lesão induzindo a expressão de citocinas pró-inflamatórias, quimiocinas e ativação de células satélites. Na medula, sugere-se que os receptores NOD1 e NOD2 são ativados possivelmente após detecção de DAMPs liberados pelos neurônios periféricos lesados e agindo via RIPK2, contribuem para o desenvolvimento da dor neuropática através da ativação de células gliais, P2X4 e liberação de citocinas pró-nociceptivas. Também, aponta-se a ação conjunta de NOD2 e TLR4 no intuito de estimular a ativação glial. Sugerese que células imunes periféricas, que se infiltram na medula espinal ou no GRD após lesão periférica, possam também expressar NOD1 e NOD2 e assim contribuir para o desenvolvimento desse processo. 


\section{Conclusão}

O conjunto dos resultados apresentados permite concluir que os receptores NOD1 e NOD2, via RIPK2, contribuem para a gênese da dor neuropática, possivelmente mediando a liberação de citocinas pró-nociceptivas e a ativação de células gliais. Além disso, os resultados apontam a ação potencial de NOD2 com TLR4 no intuito de estimular a ativação glial. Estes mecanismos representam uma nova abordagem para elucidar os mecanismos envolvidos na fisiopatologia da dor crônica e um possível alvo para o desenvolvimento de drogas para o tratamento da dor neuropática. 


\section{Referências}

Abbott DW, Wilkins A, Asara JM, Cantley LC, 2004. The Crohn's disease protein, NOD2, requires RIP2 in order to induce ubiquitinylation of a novel site on NEMO. Curr Biol 14, 2217-27.

Akira S, 2009. Pathogen recognition by innate immunity and its signaling. Proc Jpn Acad Ser B Phys Biol Sci 85, 143-56.

Asea A, Rehli M, Kabingu E, et al., 2002. Novel signal transduction pathway utilized by extracellular HSP70: role of toll-like receptor (TLR) 2 and TLR4. J Biol Chem 277, 15028-34.

Ashton KA, Proietto A, Otton G, et al., 2010. Toll-like receptor (TLR) and nucleosome-binding oligomerization domain (NOD) gene polymorphisms and endometrial cancer risk. BMC Cancer 10, 382.

Austin PJ, Moalem-Taylor G, 2010. The neuro-immune balance in neuropathic pain: involvement of inflammatory immune cells, immune-like glial cells and cytokines. $J$ Neuroimmunol 229, 26-50.

Barnich N, Aguirre JE, Reinecker HC, Xavier R, Podolsky DK, 2005. Membrane recruitment of NOD2 in intestinal epithelial cells is essential for nuclear factor$\{$ kappa $\}$ B activation in muramyl dipeptide recognition. J Cell Biol 170, 21-6.

Baron R, Binder A, 2004. [How neuropathic is sciatica? The mixed pain concept]. Orthopade 33, 568-75.

Basbaum AI, Bautista DM, Scherrer G, Julius D, 2009. Cellular and molecular mechanisms of pain. Cell 139, 267-84.

Beggs S, Salter MW, 2007. Stereological and somatotopic analysis of the spinal microglial response to peripheral nerve injury. Brain Behav Immun 21, 624-33.

Belvin MP, Anderson KV, 1996. A conserved signaling pathway: the Drosophila tolldorsal pathway. Annu Rev Cell Dev Biol 12, 393-416.

Benveniste EN, Tang LP, Law RM, 1995. Differential regulation of astrocyte TNFalpha expression by the cytokines TGF-beta, IL-6 and IL-10. Int J Dev Neurosci 13, 341-9.

Bianchi ME, 2007. DAMPs, PAMPs and alarmins: all we need to know about danger. J Leukoc Biol 81, 1-5.

Binshtok AM, Wang H, Zimmermann K, et al., 2008. Nociceptors are interleukin1beta sensors. J Neurosci 28, 14062-73.

Burnstock G, 2006. Pathophysiology and therapeutic potential of purinergic signaling. Pharmacol Rev 58, 58-86. 
Calvo M, Bennett DL, 2012. The mechanisms of microgliosis and pain following peripheral nerve injury. Exp Neurol 234, 271-82.

Calvo M, Dawes JM, Bennett DL, 2012. The role of the immune system in the generation of neuropathic pain. Lancet Neurol 11, 629-42.

Cao L, Deleo JA, 2008. CNS-infiltrating CD4+ T lymphocytes contribute to murine spinal nerve transection-induced neuropathic pain. Eur J Immunol 38, 448-58.

Cao L, Tanga FY, Deleo JA, 2009. The contributing role of CD14 in toll-like receptor 4 dependent neuropathic pain. Neuroscience 158, 896-903.

Cao YQ, Mantyh PW, Carlson EJ, Gillespie AM, Epstein CJ, Basbaum AI, 1998. Primary afferent tachykinins are required to experience moderate to intense pain. Nature 392, 390-4.

Carneiro LA, Magalhaes JG, Tattoli I, Philpott DJ, Travassos LH, 2008. Nod-like proteins in inflammation and disease. $J$ Pathol 214, 136-48.

Carpentier PA, Duncan DS, Miller SD, 2008. Glial toll-like receptor signaling in central nervous system infection and autoimmunity. Brain Behav Immun 22, 140-7.

Caruso R, Warner N, Inohara N, Nunez G, 2014. NOD1 and NOD2: signaling, host defense, and inflammatory disease. Immunity 41, 898-908.

Chamaillard M, Hashimoto M, Horie Y, et al., 2003. An essential role for NOD1 in host recognition of bacterial peptidoglycan containing diaminopimelic acid. Nat Immunol 4, 702-7.

Charo IF, Ransohoff RM, 2006. The many roles of chemokines and chemokine receptors in inflammation. $N$ Engl J Med 354, 610-21.

Chauhan VS, Sterka DG, Jr., Furr SR, Young AB, Marriott I, 2009. NOD2 plays an important role in the inflammatory responses of microglia and astrocytes to bacterial CNS pathogens. Glia 57, 414-23.

Chen G, Shaw MH, Kim YG, Nunez G, 2009. NOD-like receptors: role in innate immunity and inflammatory disease. Annu Rev Pathol 4, 365-98.

Chen GY, Shaw MH, Redondo G, Nunez G, 2008. The innate immune receptor Nod1 protects the intestine from inflammation-induced tumorigenesis. Cancer Res $\mathbf{6 8}$, 10060-7.

Chisholm ST, Coaker G, Day B, Staskawicz BJ, 2006. Host-microbe interactions: shaping the evolution of the plant immune response. Cell 124, 803-14.

Clark AK, D'aquisto F, Gentry C, Marchand F, Mcmahon SB, Malcangio M, 2006. Rapid co-release of interleukin 1 beta and caspase 1 in spinal cord inflammation. $J$ Neurochem 99, 868-80. 
Clark AK, Gentry C, Bradbury EJ, Mcmahon SB, Malcangio M, 2007. Role of spinal microglia in rat models of peripheral nerve injury and inflammation. Eur J Pain 11, 223-30.

Clark AK, Yip PK, Malcangio M, 2009. The liberation of fractalkine in the dorsal horn requires microglial cathepsin S. J Neurosci 29, 6945-54.

Cohen SP, Mao J, 2014. Neuropathic pain: mechanisms and their clinical implications. BMJ 348, f7656.

Colburn RW, Deleo JA, Rickman AJ, Yeager MP, Kwon P, Hickey WF, 1997. Dissociation of microglial activation and neuropathic pain behaviors following peripheral nerve injury in the rat. $J$ Neuroimmunol 79, 163-75.

Colburn RW, Rickman AJ, Deleo JA, 1999. The effect of site and type of nerve injury on spinal glial activation and neuropathic pain behavior. Exp Neurol 157, 289-304.

Costigan M, Mannion RJ, Kendall G, et al., 1998. Heat shock protein 27: developmental regulation and expression after peripheral nerve injury. J Neurosci 18, 5891-900.

Costigan M, Moss A, Latremoliere A, et al., 2009. T-cell infiltration and signaling in the adult dorsal spinal cord is a major contributor to neuropathic pain-like hypersensitivity. J Neurosci 29, 14415-22.

Coull JA, Beggs S, Boudreau D, et al., 2005. BDNF from microglia causes the shift in neuronal anion gradient underlying neuropathic pain. Nature 438, 1017-21.

Coutaux A, Adam F, Willer JC, Le Bars D, 2005. Hyperalgesia and allodynia: peripheral mechanisms. Joint Bone Spine 72, 359-71.

Couturier-Maillard A, Secher T, Rehman A, et al., 2013. NOD2-mediated dysbiosis predisposes mice to transmissible colitis and colorectal cancer. J Clin Invest 123, 70011.

Coyle DE, 1998. Partial peripheral nerve injury leads to activation of astroglia and microglia which parallels the development of allodynic behavior. Glia 23, 75-83.

Cunha TM, Verri WA, Jr., Silva JS, Poole S, Cunha FQ, Ferreira SH, 2005. A cascade of cytokines mediates mechanical inflammatory hypernociception in mice. Proc Natl Acad Sci U S A 102, 1755-60.

Cunha TM, Verri WA, Jr., Vivancos GG, et al., 2004. An electronic pressure-meter nociception paw test for mice. Braz J Med Biol Res 37, 401-7.

Davis BK, Wen H, Ting JP, 2011. The inflammasome NLRs in immunity, inflammation, and associated diseases. Annu Rev Immunol 29, 707-35. 
Decosterd I, Woolf CJ, 2000. Spared nerve injury: an animal model of persistent peripheral neuropathic pain. Pain 87, 149-58.

Deleo JA, Colburn RW, Nichols M, Malhotra A, 1996. Interleukin-6-mediated hyperalgesia/allodynia and increased spinal IL-6 expression in a rat mononeuropathy model. J Interferon Cytokine Res 16, 695-700.

Deleo JA, Yezierski RP, 2001. The role of neuroinflammation and neuroimmune activation in persistent pain. Pain 90, 1-6.

Denker SP, Ji S, Dingman A, et al., 2007. Macrophages are comprised of resident brain microglia not infiltrating peripheral monocytes acutely after neonatal stroke. $J$ Neurochem 100, 893-904.

Dong Y, Benveniste EN, 2001. Immune function of astrocytes. Glia 36, 180-90.

Duan W, Mehta AK, Magalhaes JG, et al., 2010. Innate signals from Nod2 block respiratory tolerance and program $\mathrm{T}(\mathrm{H}) 2$-driven allergic inflammation. J Allergy Clin Immunol 126, 1284-93 e10.

Dworkin RH, O'connor AB, Audette J, et al., 2010. Recommendations for the pharmacological management of neuropathic pain: an overview and literature update. Mayo Clin Proc 85, S3-14.

Eder W, Klimecki W, Yu L, et al., 2006. Association between exposure to farming, allergies and genetic variation in CARD4/NOD1. Allergy 61, 1117-24.

Eriksson NP, Persson JK, Svensson M, Arvidsson J, Molander C, Aldskogius H, 1993. A quantitative analysis of the microglial cell reaction in central primary sensory projection territories following peripheral nerve injury in the adult rat. Exp Brain Res 96, 19-27.

Farzi A, Reichmann F, Meinitzer A, et al., 2015. Synergistic effects of NOD1 or NOD2 and TLR4 activation on mouse sickness behavior in relation to immune and brain activity markers. Brain Behav Immun 44, 106-20.

Furuya T, Tanaka R, Urabe T, et al., 2003. Establishment of modified chimeric mice using GFP bone marrow as a model for neurological disorders. Neuroreport 14, 62931 .

Gao YJ, Ji RR, 2010. Chemokines, neuronal-glial interactions, and central processing of neuropathic pain. Pharmacol Ther 126, 56-68.

Gavet O, Pines J, 2010. Progressive activation of CyclinB1-Cdk1 coordinates entry to mitosis. Dev Cell 18, 533-43.

Geddes K, Magalhaes JG, Girardin SE, 2009. Unleashing the therapeutic potential of NOD-like receptors. Nat Rev Drug Discov 8, 465-79. 
Girardin SE, Boneca IG, Carneiro LA, et al., 2003a. Nod1 detects a unique muropeptide from gram-negative bacterial peptidoglycan. Science 300, 1584-7.

Girardin SE, Boneca IG, Viala J, et al., 2003b. Nod2 is a general sensor of peptidoglycan through muramyl dipeptide (MDP) detection. J Biol Chem 278, 886972 .

Gosselin RD, Suter MR, Ji RR, Decosterd I, 2010. Glial cells and chronic pain. Neuroscientist 16, 519-31.

Grace PM, Hutchinson MR, Maier SF, Watkins LR, 2014. Pathological pain and the neuroimmune interface. Nat Rev Immunol 14, 217-31.

Guo LH, Guo KT, Wendel HP, Schluesener HJ, 2006. Combinations of TLR and NOD2 ligands stimulate rat microglial P2X4R expression. Biochem Biophys Res Commun 349, 1156-62.

Gwak YS, Hulsebosch CE, 2009. Remote astrocytic and microglial activation modulates neuronal hyperexcitability and below-level neuropathic pain after spinal injury in rat. Neuroscience 161, 895-903.

Hahn JS, 2005. Regulation of Nod1 by Hsp90 chaperone complex. FEBS Lett 579, 4513-9.

Hansson E, Ronnback L, 2003. Glial neuronal signaling in the central nervous system. FASEB J 17, 341-8.

Hasegawa M, Yang K, Hashimoto $\mathrm{M}$, et al., 2006. Differential release and distribution of Nod1 and Nod2 immunostimulatory molecules among bacterial species and environments. J Biol Chem 281, 29054-63.

Hashimoto C, Hudson KL, Anderson KV, 1988. The Toll gene of Drosophila, required for dorsal-ventral embryonic polarity, appears to encode a transmembrane protein. Cell 52, 269-79.

Hatton GI, 1999. Astroglial modulation of neurotransmitter/peptide release from the neurohypophysis: present status. J Chem Neuroanat 16, 203-21.

Haydon PG, 2001. GLIA: listening and talking to the synapse. Nat Rev Neurosci 2 , 185-93.

Hisamatsu T, Suzuki M, Reinecker HC, Nadeau WJ, Mccormick BA, Podolsky DK, 2003. CARD15/NOD2 functions as an antibacterial factor in human intestinal epithelial cells. Gastroenterology 124, 993-1000.

Hokfelt T, Zhang X, Wiesenfeld-Hallin Z, 1994. Messenger plasticity in primary sensory neurons following axotomy and its functional implications. Trends Neurosci 17, 22-30. 
Honore P, Rogers SD, Schwei MJ, et al., 2000. Murine models of inflammatory, neuropathic and cancer pain each generates a unique set of neurochemical changes in the spinal cord and sensory neurons. Neuroscience 98, 585-98.

Hu P, Bembrick AL, Keay KA, Mclachlan EM, 2007. Immune cell involvement in dorsal root ganglia and spinal cord after chronic constriction or transection of the rat sciatic nerve. Brain Behav Immun 21, 599-616.

Hu P, Mclachlan EM, 2002. Macrophage and lymphocyte invasion of dorsal root ganglia after peripheral nerve lesions in the rat. Neuroscience 112, 23-38.

Hugot JP, Chamaillard M, Zouali H, et al., 2001. Association of NOD2 leucine-rich repeat variants with susceptibility to Crohn's disease. Nature 411, 599-603.

Hunskaar S, Hole K, 1987. The formalin test in mice: dissociation between inflammatory and non-inflammatory pain. Pain 30, 103-14.

Hutchinson MR, Ramos KM, Loram LC, et al., 2009. Evidence for a role of heat shock protein-90 in toll like receptor 4 mediated pain enhancement in rats. Neuroscience 164, 1821-32.

Hysi P, Kabesch M, Moffatt MF, et al., 2005. NOD1 variation, immunoglobulin E and asthma. Hum Mol Genet 14, 935-41.

Inohara, Chamaillard, Mcdonald C, Nunez G, 2005. NOD-LRR proteins: role in hostmicrobial interactions and inflammatory disease. Annu Rev Biochem 74, 355-83.

Inohara N, Koseki T, Del Peso L, et al., 1999. Nod1, an Apaf-1-like activator of caspase-9 and nuclear factor-kappaB. J Biol Chem 274, 14560-7.

Inohara N, Koseki T, Lin J, et al., 2000. An induced proximity model for NF-kappa B activation in the Nod1/RICK and RIP signaling pathways. J Biol Chem 275, 2782331.

Inohara N, Ogura Y, Fontalba A, et al., 2003. Host recognition of bacterial muramyl dipeptide mediated through NOD2. Implications for Crohn's disease. $J$ Biol Chem 278, 5509-12.

Inoue K, 2002. Microglial activation by purines and pyrimidines. Glia 40, 156-63.

Inoue K, Tsuda M, 2006. [The role of microglia and ATP receptors in a mechanism of neuropathic pain]. Nihon Yakurigaku Zasshi 127, 14-7.

Inoue K, Tsuda M, 2012. Purinergic systems, neuropathic pain and the role of microglia. Exp Neurol 234, 293-301.

Isami K, Haraguchi K, So K, et al., 2013. Involvement of TRPM2 in peripheral nerve injury-induced infiltration of peripheral immune cells into the spinal cord in mouse neuropathic pain model. PLoS One 8, e66410. 
Jakopin Z, 2014. Nucleotide-binding oligomerization domain (NOD) inhibitors: a rational approach toward inhibition of NOD signaling pathway. J Med Chem 57, 6897-918.

Ji RR, Xu ZZ, Gao YJ, 2014. Emerging targets in neuroinflammation-driven chronic pain. Nat Rev Drug Discov 13, 533-48.

Jin SX, Zhuang ZY, Woolf CJ, Ji RR, 2003. p38 mitogen-activated protein kinase is activated after a spinal nerve ligation in spinal cord microglia and dorsal root ganglion neurons and contributes to the generation of neuropathic pain. J Neurosci 23, 401722.

Jin X, Gereau RWT, 2006. Acute p38-mediated modulation of tetrodotoxin-resistant sodium channels in mouse sensory neurons by tumor necrosis factor-alpha. $J$ Neurosci 26, 246-55.

Johannes CB, Le TK, Zhou X, Johnston JA, Dworkin RH, 2010. The prevalence of chronic pain in United States adults: results of an Internet-based survey. J Pain 11, 1230-9.

Joosten LA, Heinhuis B, Abdollahi-Roodsaz S, et al., 2008. Differential function of the NACHT-LRR (NLR) members Nod1 and Nod2 in arthritis. Proc Natl Acad Sci U $S$ A 105, 9017-22.

Julius D, Basbaum AI, 2001. Molecular mechanisms of nociception. Nature 413, 20310 .

Jun JC, Cominelli F, Abbott DW, 2013. RIP2 activity in inflammatory disease and implications for novel therapeutics. J Leukoc Biol 94, 927-32.

Kalso E, Edwards JE, Moore RA, Mcquay HJ, 2004. Opioids in chronic non-cancer pain: systematic review of efficacy and safety. Pain 112, 372-80.

Kanazawa N, Okafuji I, Kambe N, et al., 2005. Early-onset sarcoidosis and CARD15 mutations with constitutive nuclear factor-kappaB activation: common genetic etiology with Blau syndrome. Blood 105, 1195-7.

Kang MJ, Heo SK, Song EJ, et al., 2012. Activation of Nod1 and Nod2 induces innate immune responses of prostate epithelial cells. Prostate 72, 1351-8.

Kawai T, Akira S, 2010. The role of pattern-recognition receptors in innate immunity: update on Toll-like receptors. Nat Immunol 11, 373-84.

Kawasaki Y, Xu ZZ, Wang X, et al., 2008. Distinct roles of matrix metalloproteases in the early- and late-phase development of neuropathic pain. Nat Med 14, 331-6.

Kim D, Kim MA, Cho IH, et al., 2007. A critical role of toll-like receptor 2 in nerve injury-induced spinal cord glial cell activation and pain hypersensitivity. J Biol Chem 282, 14975-83. 
Kim DS, Figueroa KW, Li KW, Boroujerdi A, Yolo T, Luo ZD, 2009. Profiling of dynamically changed gene expression in dorsal root ganglia post peripheral nerve injury and a critical role of injury-induced glial fibrillary acidic protein in maintenance of pain behaviors [corrected]. Pain 143, 114-22.

Kinsner A, Boveri M, Hareng L, et al., 2006. Highly purified lipoteichoic acid induced pro-inflammatory signalling in primary culture of rat microglia through Tolllike receptor 2: selective potentiation of nitric oxide production by muramyl dipeptide. J Neurochem 99, 596-607.

Kobayashi K, Inohara N, Hernandez LD, et al., 2002. RICK/Rip2/CARDIAK mediates signalling for receptors of the innate and adaptive immune systems. Nature 416, 194-9.

Kuang X, Huang Y, Gu HF, et al., 2012. Effects of intrathecal epigallocatechin gallate, an inhibitor of Toll-like receptor 4, on chronic neuropathic pain in rats. Eur $J$ Pharmacol 676, 51-6.

Kufer TA, Kremmer E, Adam AC, Philpott DJ, Sansonetti PJ, 2008. The patternrecognition molecule Nod1 is localized at the plasma membrane at sites of bacterial interaction. Cell Microbiol 10, 477-86.

Kumar H, Kawai T, Akira S, 2011. Pathogen recognition by the innate immune system. Int Rev Immunol 30, 16-34.

Kuraishi Y, Harada Y, Aratani S, Satoh M, Takagi H, 1983. Separate involvement of the spinal noradrenergic and serotonergic systems in morphine analgesia: the differences in mechanical and thermal algesic tests. Brain Res 273, 245-52.

Land WG, 2015. The Role of Damage-Associated Molecular Patterns in Human Diseases: Part I - Promoting inflammation and immunity. Sultan Qaboos Univ Med J 15, e9-e21.

Lao L, Zhang RX, Zhang G, Wang X, Berman BM, Ren K, 2004. A parametric study of electroacupuncture on persistent hyperalgesia and Fos protein expression in rats. Brain Res 1020, 18-29.

Lawson LJ, Perry VH, Gordon S, 1992. Turnover of resident microglia in the normal adult mouse brain. Neuroscience 48, 405-15.

Ledeboer A, Gamanos M, Lai W, et al., 2005. Involvement of spinal cord nuclear factor kappaB activation in rat models of proinflammatory cytokine-mediated pain facilitation. Eur J Neurosci 22, 1977-86.

Lee HL, Lee KM, Son SJ, Hwang SH, Cho HJ, 2004. Temporal expression of cytokines and their receptors mRNAs in a neuropathic pain model. Neuroreport 15, 2807-11. 
Lee KH, Biswas A, Liu YJ, Kobayashi KS, 2012. Proteasomal degradation of Nod2 protein mediates tolerance to bacterial cell wall components. J Biol Chem 287, 3980011 .

Lee S, Zhao YQ, Ribeiro-Da-Silva A, Zhang J, 2010. Distinctive response of CNS glial cells in oro-facial pain associated with injury, infection and inflammation. Mol Pain 6, 79.

Lemaitre B, Nicolas E, Michaut L, Reichhart JM, Hoffmann JA, 1996. The dorsoventral regulatory gene cassette spatzle/Toll/cactus controls the potent antifungal response in Drosophila adults. Cell 86, 973-83.

Lin T, Li K, Zhang FY, Zhang ZK, Light AR, Fu KY, 2007. Dissociation of spinal microglia morphological activation and peripheral inflammation in inflammatory pain models. J Neuroimmunol 192, 40-8.

Liu X, Chauhan VS, Marriott I, 2010a. NOD2 contributes to the inflammatory responses of primary murine microglia and astrocytes to Staphylococcus aureus. Neurosci Lett 474, 93-8.

Liu X, Chauhan VS, Young AB, Marriott I, 2010b. NOD2 mediates inflammatory responses of primary murine glia to Streptococcus pneumoniae. Glia 58, 839-47.

Loeser JD, Melzack R, 1999. Pain: an overview. Lancet 353, 1607-9.

Luo F, Wang JY, 2009. Neuronal nociceptive responses in thalamocortical pathways. Neurosci Bull 25, 289-95.

Macaluso F, Nothnagel M, Parwez Q, et al., 2007. Polymorphisms in NACHT-LRR (NLR) genes in atopic dermatitis. Exp Dermatol 16, 692-8.

Maisonneuve C, Bertholet S, Philpott DJ, De Gregorio E, 2014. Unleashing the potential of NOD- and Toll-like agonists as vaccine adjuvants. Proc Natl Acad Sci U $S$ A 111, 12294-9.

Manjavachi MN, Costa R, Quintao NL, Calixto JB, 2014. The role of keratinocytederived chemokine (KC) on hyperalgesia caused by peripheral nerve injury in mice. Neuropharmacology 79, 17-27.

Marchand F, Tsantoulas C, Singh D, et al., 2009. Effects of Etanercept and Minocycline in a rat model of spinal cord injury. Eur J Pain 13, 673-81.

Marriott I, Rati DM, Mccall SH, Tranguch SL, 2005. Induction of Nod1 and Nod2 intracellular pattern recognition receptors in murine osteoblasts following bacterial challenge. Infect Immun 73, 2967-73.

Mayor A, Martinon F, De Smedt T, Petrilli V, Tschopp J, 2007. A crucial function of SGT1 and HSP90 in inflammasome activity links mammalian and plant innate immune responses. Nat Immunol 8, 497-503. 
Mcmahon SB, Cafferty WB, Marchand F, 2005. Immune and glial cell factors as pain mediators and modulators. Exp Neurol 192, 444-62.

Medzhitov R, Preston-Hurlburt P, Janeway CA, Jr., 1997. A human homologue of the Drosophila Toll protein signals activation of adaptive immunity. Nature 388, 394-7.

Meller ST, Dykstra C, Grzybycki D, Murphy S, Gebhart GF, 1994. The possible role of glia in nociceptive processing and hyperalgesia in the spinal cord of the rat. Neuropharmacology 33, 1471-8.

Meylan E, Tschopp J, Karin M, 2006. Intracellular pattern recognition receptors in the host response. Nature 442, 39-44.

Miceli-Richard C, Lesage S, Rybojad M, et al., 2001. CARD15 mutations in Blau syndrome. Nat Genet 29, 19-20.

Mika J, Zychowska M, Popiolek-Barczyk K, Rojewska E, Przewlocka B, 2013. Importance of glial activation in neuropathic pain. Eur J Pharmacol 716, 106-19.

Millan MJ, Czlonkowski A, Morris B, et al., 1988. Inflammation of the hind limb as a model of unilateral, localized pain: influence on multiple opioid systems in the spinal cord of the rat. Pain 35, 299-312.

Milligan ED, O'connor KA, Nguyen KT, et al., 2001. Intrathecal HIV-1 envelope glycoprotein gp120 induces enhanced pain states mediated by spinal cord proinflammatory cytokines. J Neurosci $\mathbf{2 1}$, 2808-19.

Milligan ED, Watkins LR, 2009. Pathological and protective roles of glia in chronic pain. Nat Rev Neurosci 10, 23-36.

Milligan ED, Zapata V, Chacur M, et al., 2004. Evidence that exogenous and endogenous fractalkine can induce spinal nociceptive facilitation in rats. Eur $J$ Neurosci 20, 2294-302.

Mohanan V, Grimes CL, 2014. The molecular chaperone HSP70 binds to and stabilizes NOD2, an important protein involved in Crohn disease. J Biol Chem 289, 18987-98.

Moreira LO, Zamboni DS, 2012. NOD1 and NOD2 Signaling in Infection and Inflammation. Front Immunol 3, 328.

Morin N, Owolabi SA, Harty MW, et al., 2007. Neutrophils invade lumbar dorsal root ganglia after chronic constriction injury of the sciatic nerve. J Neuroimmunol 184, 164-71.

Natsuka M, Uehara A, Yang S, Echigo S, Takada H, 2008. A polymer-type watersoluble peptidoglycan exhibited both Toll-like receptor 2- and NOD2-agonistic activities, resulting in synergistic activation of human monocytic cells. Innate Immun 14, 298-308. 
Nguyen MD, Julien JP, Rivest S, 2002. Innate immunity: the missing link in neuroprotection and neurodegeneration? Nat Rev Neurosci 3, 216-27.

Nicotra L, Loram LC, Watkins LR, Hutchinson MR, 2012. Toll-like receptors in chronic pain. Exp Neurol 234, 316-29.

Ogura Y, Bonen DK, Inohara N, et al., 2001a. A frameshift mutation in NOD2 associated with susceptibility to Crohn's disease. Nature 411, 603-6.

Ogura Y, Inohara N, Benito A, Chen FF, Yamaoka S, Nunez G, 2001b. Nod2, a Nod1/Apaf-1 family member that is restricted to monocytes and activates NF-kappaB. J Biol Chem 276, 4812-8.

Ohashi K, Burkart V, Flohe S, Kolb H, 2000. Cutting edge: heat shock protein 60 is a putative endogenous ligand of the toll-like receptor-4 complex. J Immunol 164, 55861.

Old EA, Malcangio M, 2012. Chemokine mediated neuron-glia communication and aberrant signalling in neuropathic pain states. Curr Opin Pharmacol 12, 67-73.

Olson JK, Miller SD, 2004. Microglia initiate central nervous system innate and adaptive immune responses through multiple TLRs. J Immunol 173, 3916-24.

Ozaktay AC, Kallakuri S, Takebayashi T, et al., 2006. Effects of interleukin-1 beta, interleukin-6, and tumor necrosis factor on sensitivity of dorsal root ganglion and peripheral receptive fields in rats. Eur Spine J 15, 1529-37.

Parada CA, Tambeli CH, Cunha FQ, Ferreira SH, 2001. The major role of peripheral release of histamine and 5-hydroxytryptamine in formalin-induced nociception. Neuroscience 102, 937-44.

Park JH, Kim YG, Mcdonald C, et al., 2007. RICK/RIP2 mediates innate immune responses induced through Nod1 and Nod2 but not TLRs. J Immunol 178, 2380-6.

Patro N, Nagayach A, Patro IK, 2010. Iba1 expressing microglia in the dorsal root ganglia become activated following peripheral nerve injury in rats. Indian J Exp Biol 48, 110-6.

Piccinini AM, Midwood KS, 2010. DAMPening inflammation by modulating TLR signalling. Mediators Inflamm 2010.

Piehl F, Lidman O, 2001. Neuroinflammation in the rat--CNS cells and their role in the regulation of immune reactions. Immunol Rev 184, 212-25.

Priller J, Flugel A, Wehner T, et al., 2001. Targeting gene-modified hematopoietic cells to the central nervous system: use of green fluorescent protein uncovers microglial engraftment. Nat Med 7, 1356-61.

Priller J, Prinz M, Heikenwalder M, et al., 2006. Early and rapid engraftment of bone marrow-derived microglia in scrapie. J Neurosci 26, 11753-62. 
Prinz M, Priller J, 2014. Microglia and brain macrophages in the molecular age: from origin to neuropsychiatric disease. Nat Rev Neurosci 15, 300-12.

Quintao NL, Medeiros R, Santos AR, Campos MM, Calixto JB, 2005. The effects of diacerhein on mechanical allodynia in inflammatory and neuropathic models of nociception in mice. Anesth Analg 101, 1763-9.

Raghavendra V, Tanga F, Deleo JA, 2003. Inhibition of microglial activation attenuates the development but not existing hypersensitivity in a rat model of neuropathy. J Pharmacol Exp Ther 306, 624-30.

Raghavendra V, Tanga FY, Deleo JA, 2004. Complete Freunds adjuvant-induced peripheral inflammation evokes glial activation and proinflammatory cytokine expression in the CNS. Eur J Neurosci 20, 467-73.

Raivich G, Banati R, 2004. Brain microglia and blood-derived macrophages: molecular profiles and functional roles in multiple sclerosis and animal models of autoimmune demyelinating disease. Brain Res Brain Res Rev 46, 261-81.

Reeve AJ, Patel S, Fox A, Walker K, Urban L, 2000. Intrathecally administered endotoxin or cytokines produce allodynia, hyperalgesia and changes in spinal cord neuronal responses to nociceptive stimuli in the rat. Eur J Pain 4, 247-57.

Ren K, 2010. Emerging role of astroglia in pain hypersensitivity. Jpn Dent Sci Rev 46, 86.

Ren K, Dubner R, 2010. Interactions between the immune and nervous systems in pain. Nat Med 16, 1267-76.

Ren PC, Zhang Y, Zhang XD, et al., 2012. High-mobility group box 1 contributes to mechanical allodynia and spinal astrocytic activation in a mouse model of type 2 diabetes. Brain Res Bull 88, 332-7.

Ribes S, Adam N, Schutze S, et al., 2012. The nucleotide-binding oligomerization domain-containing-2 ligand muramyl dipeptide enhances phagocytosis and intracellular killing of Escherichia coli K1 by Toll-like receptor agonists in microglial cells. J Neuroimmunol 252, 16-23.

Richner M, Bjerrum OJ, Nykjaer A, Vaegter CB, 2011. The spared nerve injury (SNI) model of induced mechanical allodynia in mice. J Vis Exp.

Romero-Sandoval A, Chai N, Nutile-Mcmenemy N, Deleo JA, 2008. A comparison of spinal Iba1 and GFAP expression in rodent models of acute and chronic pain. Brain Res 1219, 116-26.

Saijo K, Crotti A, Glass CK, 2013. Regulation of microglia activation and deactivation by nuclear receptors. Glia 61, 104-11. 
Saito O, Svensson CI, Buczynski MW, et al., 2010. Spinal glial TLR4-mediated nociception and production of prostaglandin E(2) and TNF. Br J Pharmacol 160, 1754-64.

Sandkuhler J, 2009. Models and mechanisms of hyperalgesia and allodynia. Physiol $\operatorname{Rev}$ 89, 707-58.

Sato T, Shikama Y, Shimauchi H, Endo Y, Takada H, 2011. Analgesic effects of chemically synthesized NOD1 and NOD2 agonists in mice. Innate Immun 17, 54-9.

Sauer RS, Hackel D, Morschel L, et al., 2014. Toll like receptor (TLR)-4 as a regulator of peripheral endogenous opioid-mediated analgesia in inflammation. $\mathrm{Mol}$ Pain 10, 10.

Sawada A, Niiyama Y, Ataka K, Nagaishi K, Yamakage M, Fujimiya M, 2014. Suppression of bone marrow-derived microglia in the amygdala improves anxiety-like behavior induced by chronic partial sciatic nerve ligation in mice. Pain 155, 1762-72.

Scholz J, Woolf CJ, 2002. Can we conquer pain? Nat Neurosci 5 Suppl, 1062-7.

Scholz J, Woolf CJ, 2007. The neuropathic pain triad: neurons, immune cells and glia. Nat Neurosci 10, 1361-8.

Seltzer Z, Dubner R, Shir Y, 1990. A novel behavioral model of neuropathic pain disorders produced in rats by partial sciatic nerve injury. Pain 43, 205-18.

Shields SD, Eckert WA, 3rd, Basbaum AI, 2003. Spared nerve injury model of neuropathic pain in the mouse: a behavioral and anatomic analysis. $J$ Pain 4, 465-70.

Sofroniew MV, Vinters HV, 2010. Astrocytes: biology and pathology. Acta Neuropathol 119, 7-35.

Solomon JN, Lewis CA, Ajami B, Corbel SY, Rossi FM, Krieger C, 2006. Origin and distribution of bone marrow-derived cells in the central nervous system in a mouse model of amyotrophic lateral sclerosis. Glia 53, 744-53.

Sterka D, Jr., Marriott I, 2006. Characterization of nucleotide-binding oligomerization domain (NOD) protein expression in primary murine microglia. J Neuroimmunol 179, $65-75$.

Sterka D, Jr., Rati DM, Marriott I, 2006. Functional expression of NOD2, a novel pattern recognition receptor for bacterial motifs, in primary murine astrocytes. Glia 53, 322-30.

Streit WJ, Graeber MB, Kreutzberg GW, 1989. Expression of Ia antigen on perivascular and microglial cells after sublethal and lethal motor neuron injury. Exp Neurol 105, 115-26.

Strober W, Murray PJ, Kitani A, Watanabe T, 2006. Signalling pathways and molecular interactions of NOD1 and NOD2. Nat Rev Immunol 6, 9-20. 
Stucky CL, Gold MS, Zhang X, 2001. Mechanisms of pain. Proc Natl Acad Sci U S A 98, 11845-6.

Sun JH, Yang B, Donnelly DF, Ma C, Lamotte RH, 2006. MCP-1 enhances excitability of nociceptive neurons in chronically compressed dorsal root ganglia. $J$ Neurophysiol 96, 2189-99.

Sweitzer SM, Colburn RW, Rutkowski M, Deleo JA, 1999. Acute peripheral inflammation induces moderate glial activation and spinal IL-1beta expression that correlates with pain behavior in the rat. Brain Res 829, 209-21.

Sweitzer SM, Hickey WF, Rutkowski MD, Pahl JL, Deleo JA, 2002. Focal peripheral nerve injury induces leukocyte trafficking into the central nervous system: potential relationship to neuropathic pain. Pain 100, 163-70.

Takeda K, Akira S, 2005. Toll-like receptors in innate immunity. Int Immunol 17, 114.

Takeuchi O, Akira S, 2010. Pattern recognition receptors and inflammation. Cell 140, 805-20.

Taktak YS, Selkirk S, Bristow AF, et al., 1991. Assay of pyrogens by interleukin-6 release from monocytic cell lines. J Pharm Pharmacol 43, 578-82.

Tanabe T, Ishige I, Suzuki Y, et al., 2006. Sarcoidosis and NOD1 variation with impaired recognition of intracellular Propionibacterium acnes. Biochim Biophys Acta 1762, 794-801.

Tanga FY, Nutile-Mcmenemy N, Deleo JA, 2005. The CNS role of Toll-like receptor 4 in innate neuroimmunity and painful neuropathy. Proc Natl Acad Sci U S A 102, 5856-61.

Tanga FY, Raghavendra V, Deleo JA, 2004. Quantitative real-time RT-PCR assessment of spinal microglial and astrocytic activation markers in a rat model of neuropathic pain. Neurochem Int 45, 397-407.

Tawfik VL, Nutile-Mcmenemy N, Lacroix-Fralish ML, Deleo JA, 2007. Efficacy of propentofylline, a glial modulating agent, on existing mechanical allodynia following peripheral nerve injury. Brain Behav Immun 21, 238-46.

Temporin K, Tanaka H, Kuroda Y, et al., 2008. IL-1beta promotes neurite outgrowth by deactivating RhoA via p38 MAPK pathway. Biochem Biophys Res Commun $\mathbf{3 6 5}$, $375-80$.

Terayama R, Omura S, Fujisawa N, Yamaai T, Ichikawa H, Sugimoto T, 2008. Activation of microglia and p38 mitogen-activated protein kinase in the dorsal column nucleus contributes to tactile allodynia following peripheral nerve injury. Neuroscience 153, 1245-55. 
Tigno-Aranjuez JT, Asara JM, Abbott DW, 2010. Inhibition of RIP2's tyrosine kinase activity limits NOD2-driven cytokine responses. Genes Dev 24, 2666-77.

Tigno-Aranjuez JT, Benderitter P, Rombouts F, et al., 2014. In vivo inhibition of RIPK2 kinase alleviates inflammatory disease. J Biol Chem 289, 29651-64.

Tjolsen A, Berge OG, Hunskaar S, Rosland JH, Hole K, 1992. The formalin test: an evaluation of the method. Pain 51, 5-17.

Tong W, Wang W, Huang J, Ren N, Wu SX, Li YQ, 2010. Spinal high-mobility group box 1 contributes to mechanical allodynia in a rat model of bone cancer pain. Biochem Biophys Res Commun 395, 572-6.

Trang T, Beggs S, Salter MW, 2006. Purinoceptors in microglia and neuropathic pain. Pflugers Arch 452, 645-52.

Trang T, Beggs S, Salter MW, 2012. ATP receptors gate microglia signaling in neuropathic pain. Exp Neurol 234, 354-61.

Tsuda M, Inoue K, Salter MW, 2005. Neuropathic pain and spinal microglia: a big problem from molecules in "small" glia. Trends Neurosci 28, 101-7.

Tsuda M, Shigemoto-Mogami Y, Koizumi S, et al., 2003. P2X4 receptors induced in spinal microglia gate tactile allodynia after nerve injury. Nature 424, 778-83.

Uehara A, Fujimoto Y, Fukase K, Takada H, 2007. Various human epithelial cells express functional Toll-like receptors, NOD1 and NOD2 to produce anti-microbial peptides, but not proinflammatory cytokines. Mol Immunol 44, 3100-11.

Uehara A, Sugawara Y, Kurata S, et al., 2005. Chemically synthesized pathogenassociated molecular patterns increase the expression of peptidoglycan recognition proteins via toll-like receptors, NOD1 and NOD2 in human oral epithelial cells. Cell Microbiol 7, 675-86.

Uematsu S, Akira S, 2007. Toll-like receptors and Type I interferons. J Biol Chem 282, 15319-23.

Vabulas RM, Ahmad-Nejad P, Ghose S, Kirschning CJ, Issels RD, Wagner H, 2002. HSP70 as endogenous stimulus of the Toll/interleukin-1 receptor signal pathway. $J$ Biol Chem 277, 15107-12.

Van Heel DA, Ghosh S, Butler M, et al., 2005. Synergistic enhancement of Toll-like receptor responses by NOD1 activation. Eur J Immunol 35, 2471-6.

Van Noort JM, 2008. Stress proteins in CNS inflammation. J Pathol 214, 267-75.

Vieira SM, Cunha TM, Franca RF, et al., 2012. Joint NOD2/RIPK2 signaling regulates IL-17 axis and contributes to the development of experimental arthritis. $J$ Immunol 188, 5116-22. 
Vilhardt F, 2005. Microglia: phagocyte and glia cell. Int J Biochem Cell Biol 37, 1721.

Voss E, Wehkamp J, Wehkamp K, Stange EF, Schroder JM, Harder J, 2006. NOD2/CARD15 mediates induction of the antimicrobial peptide human betadefensin-2. J Biol Chem 281, 2005-11.

Wagner R, Myers RR, 1996. Schwann cells produce tumor necrosis factor alpha: expression in injured and non-injured nerves. Neuroscience 73, 625-9.

Walker K, Perkins M, Dray A, 1995. Kinins and kinin receptors in the nervous system. Neurochem Int 26, 1-16; discussion 7-26.

Wall PD, Gutnick M, 1974. Properties of afferent nerve impulses originating from a neuroma. Nature 248, 740-3.

Wang X, Kuivaniemi H, Bonavita G, et al., 2002. CARD15 mutations in familial granulomatosis syndromes: a study of the original Blau syndrome kindred and other families with large-vessel arteritis and cranial neuropathy. Arthritis Rheum 46, 30415 .

Watkins LR, Hutchinson MR, Johnston IN, Maier SF, 2005. Glia: novel counterregulators of opioid analgesia. Trends Neurosci 28, 661-9.

Watkins LR, Hutchinson MR, Ledeboer A, Wieseler-Frank J, Milligan ED, Maier SF, 2007. Norman Cousins Lecture. Glia as the "bad guys": implications for improving clinical pain control and the clinical utility of opioids. Brain Behav Immun 21, 13146.

Watkins LR, Maier SF, 2003. Glia: a novel drug discovery target for clinical pain. Nat Rev Drug Discov 2, 973-85.

Watkins LR, Milligan ED, Maier SF, 2001. Glial activation: a driving force for pathological pain. Trends Neurosci 24, 450-5.

Watkins LR, Milligan ED, Maier SF, 2003. Glial proinflammatory cytokines mediate exaggerated pain states: implications for clinical pain. Adv Exp Med Biol 521, 1-21.

Wieseler-Frank J, Maier SF, Watkins LR, 2004. Glial activation and pathological pain. Neurochem Int 45, 389-95.

Wolfert MA, Murray TF, Boons GJ, Moore JN, 2002. The origin of the synergistic effect of muramyl dipeptide with endotoxin and peptidoglycan. J Biol Chem 277, 39179-86.

Woolf CJ, 2011. Central sensitization: implications for the diagnosis and treatment of pain. Pain 152, S2-15.

Woolf CJ, Mannion RJ, 1999. Neuropathic pain: aetiology, symptoms, mechanisms, and management. Lancet 353, 1959-64. 
Woolf CJ, Salter MW, 2000. Neuronal plasticity: increasing the gain in pain. Science 288, 1765-9.

Yaksh TL, Rudy TA, 1976. Analgesia mediated by a direct spinal action of narcotics. Science 192, 1357-8.

Yaksh TL, Rudy TA, 1977. Studies on the direct spinal action of narcotics in the production of analgesia in the rat. J Pharmacol Exp Ther 202, 411-28.

Yeung JC, Yaksh TL, Rudy TA, 1977. Concurrent mapping of brain sites for sensitivity to the direct application of morphine and focal electrical stimulation in the production of antinociception in the rat. Pain 4, 23-40.

Zhang J, Shi XQ, Echeverry S, Mogil JS, De Koninck Y, Rivest S, 2007. Expression of CCR2 in both resident and bone marrow-derived microglia plays a critical role in neuropathic pain. J Neurosci 27, 12396-406.

Zheng W, Zheng X, Liu S, et al., 2012. TNFalpha and IL-1beta are mediated by both TLR4 and Nod1 pathways in the cultured HAPI cells stimulated by LPS. Biochem Biophys Res Commun 420, $762-7$.

Zimmermann M, 1983. Ethical guidelines for investigations of experimental pain in conscious animals. Pain 16, 109-10.

Zimmermann M, 2001. Pathobiology of neuropathic pain. Eur J Pharmacol 429, 23 37.

Zou W, Zhan X, Li M, et al., 2012. Identification of differentially expressed proteins in the spinal cord of neuropathic pain models with PKCgamma silence by proteomic analysis. Brain Res 1440, 34-46. 
Anexos 


\section{Anexos}

\subsection{Comitê de ética}

UNIVERSIDADE DE SÃO PAULO
FACULDADE DE MEDICINA DE RIBEIRÃO PRETO

\section{CER TIFICADO}

Certificamos que o Protocolo para Uso de Animais em Experimentação $\mathrm{n}^{\circ}$ 106/2011, sobre o projeto intitulado "Investigação do papel dos receptores intracelulares NOD1 e NOD2 na fisiopatologia da dor crônica", sob a responsabilidade do Professor Doutor Thiago Mattar Cunha está de acordo com os Princípios Éticos na Experimentação Animal adotado pelo Colégio Brasileiro de Experimentação Animal (COBEA) e foi APROVADO em reunião de 29 de agosto de 2011.

(We certify that the protocol $n^{\circ} 106 / 2011$, about "Investigation of the role of intracellular receptors NOD1 and NOD2 in the physiopathology of chronic pain", agrees with the ETHICAL PRINCIPLES IN ANIMAL RESEARCH adopted by Brazilian College of Animal Experimentation (COBEA) and was approved by the College of Medicine of Ribeirão Preto of the University of São Paulo - Ethical Commission of Ethics in Animal Research (CETEA) in 08/29/2011.

Ribeirão Preto, 29 de agosto de 2011.

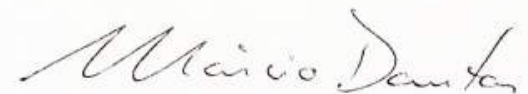

Prof. Dr. Márcio Dantas

Presidente da Comissão de Ética em Experimentação Animal 


\subsection{Manuscrito para publicação (em elaboração)}

NOD1 and NOD2 contribute to the genesis of neuropathic pain and are involved in spinal cord glial cells activation

Flávia V. Santa-Cecília ${ }^{1}$, David W. Ferreira ${ }^{1}$, Miriam M. Fonseca ${ }^{1}$, Guilherme R. de Souza $^{1}$, Dario S. Zamboni ${ }^{2}$, Fernando Q. Cunha ${ }^{1}$, Thiago M. Cunha ${ }^{1 *}$

${ }^{1}$ Department of Pharmacology, Ribeirão Preto Medical School, University of São Paulo (USP), Ribeirão Preto, SP, Brazil.

${ }^{2}$ Department of Celular Biology, Ribeirão Preto Medical School, University of São Paulo (USP), Ribeirão Preto, SP, Brazil.

*Corresponding author:

Department of Pharmacology, Ribeirão Preto Medical School, University of São Paulo, Av. Bandeirantes 3900, CEP 14049-900, RibeirãoPreto, São Paulo State, Brazil. Phone: +55 16 3602-0199; Fax: +55 16 3633-2301. E-mail: thicunha@fmrp.usp.br

Keywords: Nod-like receptors, neuropathic pain, nociception, glial cells 


\section{ABSTRACT}

Among pattern recognition receptors (PRRs), the Toll-like receptors (TLRs) and Nodlike receptors (NLRs) are the most important in recognizing the pathogen-associated molecular patterns (PAMPs). NOD2 are responsible by intracellular detection of muramyl dipeptide (MDP) and NOD1 detects meso-diaminopimelic acid (iE-DAP), PAMPs found in the peptidoglycan from bacteria. Upon recognition, NLRs recruit directly RIPK2, an adaptor protein, important in NLRs-mediated NFאB activation. PRRs play a crucial role in the activation of spinal cord glial cells and in the induction and maintenance of neuropathic pain. In the present study, we aimed to evaluate the role of receptors NOD1 and NOD2 in the genesis of neuropathic chronic pain, focusing on their signaling pathways (RIPK2), release of pronociceptive cytokines and activation of glial cells. The experiments were carried out on male C57BL/6(WT), male NOD1, NOD2, RIPK2 deficient (-/-) mice. All animal care and experimental procedures were conducted according to the guidelines of the Ethics Committee (106/2011) of FMRP-USP. Mice were submitted to the Spared Nerve Injury neuropathy model. The mechanical threshold was determined by application of von Frey filaments. The gene expression levels were determined by RT-PCR, ELISA and Western blot. Brains of newborn C57BL/6 mice were used to prepare primary microglial cell cultures. After stimulation, the supernatants were used to evaluate the

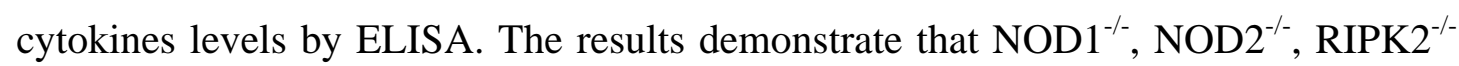
showed a significant reduction in mechanical hypersensitivity after peripheral nerve injury when compared to WT. Interestingly, CFA-induced chronic inflammatory hyperalgesia was not reduced in these mice. The reduction in neuropathic pain in $\mathrm{NOD}^{-{ }^{-}}$, $\mathrm{NOD}^{-\gamma_{-}^{-}}$and RIPK $2^{-\gamma_{-}}$mice was associated with a reduction in the expression of Iba-1, GFAP, IL-1 $\beta$ and TNF- $\alpha$ in spinal cord when compared with WT. In vitro, it was observed that primary cultures of microglia did not produce IL- $1 \beta$, TNF- $\alpha$, IL-6 in response to MDP $(3 \mu \mathrm{g} / \mathrm{mL})$ or $\mathrm{iE}-\mathrm{DAP}(100 \mathrm{ng} / \mathrm{mL})$. However, MDP, together with an ineffective concentration of LPS $(0.1 \mathrm{ng} / \mathrm{mL})$, produced a robust production of these cytokines. The results suggest that NOD1 and NOD2, via RIPK2, contribute to the genesis of neuropathic pain, possibly by mediating the release of pronociceptive cytokines and increased glial cells activation. Moreover, it seems that NOD2 activation seems to synergy with TLR4 in attempt to stimulate glial cells activation. These mechanisms represent a novel approach for elucidating the pathophysiology of 
chronic pain, and a target for the development of drugs for the treatment of neuropathic pain.

\section{Introduction}

Chronic pain is a rising health problem affecting approximately $30 \%$ of people worldwide (Ji et al., 2014) and may be divided into inflammatory pain following tissue injury, cancer pain and neuropathic pain, developing as the result of central or peripheral nervous system damage (Mika et al., 2013, Honore et al., 2000; Xu et al., 2013; Costigan et al., 2009). About 15-25\% of people who report chronic pain are currently thought to have predominantly neuropathic pain (Cohen and Mao, 2014), which typically develops after peripheral nerves are damaged by surgery, bone compression in cancer, diabetes, infection, or physical injury (Trang et al., 2012).

Much of the initial research on neuropathic pain focused on the properties of neuron transmission, but over the past two decades, there has been an explosion of studies which have provided compelling evidence that this pathogenesis is involved with other cell types, including glial cells in spinal cord, wherein the interaction neuron-glia are critical in establishing and maintaining pain hypersensitivity (Austin and Moalem-Taylor, 2010; Marchand et al., 2005; Scholz and Woolf, 2007; Suter et al., 2007; Tsuda et al., 2005). Spinal microglial activation triggers the production and release of pro-inflammatory cytokines, including TNF $\alpha$, IL-1 $\beta$ and IL-6 (DeLeo and Yezierski, 2001; Watkins and Maier, 2003; Wieseler-Frank et al., 2004; Inoue, 2006) and upregulate the expression of P2X4 (Tsuda et al., 2003), a purinergic receptor that respond to extracellular ATP, evoking responses such as the production of brainderived neurotrophic factor (BDNF), which contribute to the changes in second order neuronal excitability seen following nerve injury that underlie neuropathic pain behaviors (Coull et al., 2005, Trang et al., 2009).

Recent discoveries have implicated that pattern recognition receptors (PRRs) of the innate immune system also play a crucial role in the activation of glial cells in the spinal cord and contribute to neuropathic process (Tanga et al, 2005; Nicotra et al., 2012). Among the PRRs, the Toll-like receptors (TLRs) and Nod-like receptors (NLRs) have been extensively investigated, and are responsible for the first line of defense against infectious agents, recognizing a wide variety of pathogen-associated molecular patterns (PAMPs) (Takeuchi and Akira, 2010; Kumar et al., 2011; Kawai 
and Akira, 2009 Martinon and Tschopp, 2005). Moreover, damaged first-order sensory neurons may also release damage associated molecular patterns (DAMPs), that are endogenous signals capable of activating these receptors, which is hypothesized to be the source of TLRs activation under neuropathic conditions (Tanga et al., 2005; Kim et al., 2007; Nicotra et al., 2012; Grace et al., 2014). The interruption of specific members of the TLR family, TLR2 or TLR4, with a knockout or antisense knockdown mouse resulted in attenuation of pain hypersensitivity and reduced gliosis following spinal nerve transection (Tanga et al., 2005 Cao et al., 2009; Kuang et al., 2012). Furthermore, the pro-inflammatory cytokine expression was abolished in TLR2-deficient microglia treated with conditioned media from damaged sensory neurons (Kim et al., 2007).

The NOD1 and NOD2 receptors represent two well-characterized PRRs of the intracellular NOD-like receptors (NLRs) family (Inohara et al., 1999; Ogura et al., 2001). They share two common domains, the centrally nucleotide-binding oligomerization domain (NBD) and the C-terminal domain of leucine rich repeats (LRRs). Whereas NOD1 contains a single caspase activation and recruitment Nterminal domain (CARD), NOD2 has two (Meylan et al., 2006; Inohara et al., 2005; Strober et al., 2006). These receptors were shown to recognize different fragments of the bacterial cell wall. NOD1 detects and binds to g-D-glutamyl- mesodiaminopimelic acid (iE-DAP), a motif present in many Gram- bacteria and certain Gram+ bacteria (Chamaillard et al., 2003; Hasegawa et al., 2006). The muramyl dipeptide (MDP), a peptidoglycan motif widely distributed between both Gram+ and Gram- bacteria, is sufficient to trigger NOD2 activity (Girardin et al., 2003; Inohara et al., 2003).

Upon recognition of these PAMPs, NOD1 and NOD2, recruit directly receptor-interacting serine/threonine-protein kinase 2 (RIPK2), an adaptor protein, important in NLRs-mediated nuclear factor kappa B (NFKB) activation and induce the transcription of pro-inflammatory genes (Inohara et al., 1999; Ogura et al., 2001; Hasegawa et al., 2008). Evidences suggest that glial cells express these receptors (Zheng et al., 2012; Sterka and Marriot 2006; Sterka et al., 2006; Chauhan et al., 2009; Liu et al, 2010a,b), which indicate their role as innate immune cells in the central nervous system. It has also been reported that the co-stimulation of TLRs and NLRs induce the microglia activation, upregulation of P2X4 and consequently the production of pro-inflammatory cytokines (Guo et al., 2006). Thus, it is possible that 
NOD1 and NOD2 may be important for microglia activation and that they could contribute to pain hypersensitivity in chronic pain models. Therefore, the involvement of NOD1 and NOD2, via RIPK2, in the development of neuropathic pain has been investigated.

\section{Material and methods}

\subsection{Animals}

The experiments were performed on male and female C57BL/6 WT mice, and male NOD1, NOD2 and RIPK2 knockout mice, weighing between 20-25 g. They were housed in temperature-controlled rooms $\left(22-25^{\circ} \mathrm{C}\right)$ and given water and food ad libitum at the animal facility in the Department of Pharmacology, School of Medicine of Ribeirão Preto, University of São Paulo, Brazil. Animal care and handling procedures were in accordance with the guidelines of the International Association for Study of Pain (IASP) and with the approval of the Animal Ethics Committee of the School of Medicine of Ribeirão Preto, University of São Paulo - USP.

\subsection{Drugs}

Drugs were purchased from the following sources: MDP (Sigma-Aldrich, USA), iE-DAP (Invivogen, USA) LPS from Escherichia coli 0111: B4 (SigmaAldrich, USA), formalin (Merck, Germany) and CFA (Sigma, USA). All drugs were dissolved in sterile water whereas doses were selected based on previous standardization.

\subsection{Induction of neuropathic pain}

The spared nerve injury (SNI) model of peripheral nerve injury was used as it has several advantages over other models. Surgery was performed as described previously (Decosterd and Woolf, 2000). Briefly, mice were anaesthetized by isofluorane inhalation and the right sciatic nerve exposed under aseptic conditions. The distal trifurcation of the sciatic nerve was identified and the tibial and common 
peroneal branches ligated and cut, leaving the sural branch intact. The wound was sutured closed and the animals allowed to recover and returned to their housing.

\subsection{Induction of peripheral inflammation}

Inflammation was induced with CFA suspended in saline $(1: 1)$ and injected ( $0.1 \mathrm{~mL}$, mycobacterium, sc) into the plantar surface of the right hind paw.

\subsection{Behavioral test}

\subsection{1. von Frey filaments}

The evaluation of the mechanical hypernociception in mice was performed as described previously (Cunha et al., 2004). A series of von Frey filaments (Stoelting, Chicago, IL, USA ) with increased stiffness (0.008 to $2 \mathrm{~g}$ force) was applied to the center of the right hind paw. The stimulus was stopped after observation of the nociceptive response characterized by flexion followed by paw withdrawal, flinch. Each of the von Frey filaments was applied once for about $3 \mathrm{sec}$. Thus, the filament of lower force able to induce response was determined as the mechanical withdrawal threshold (log g).

\subsubsection{Formalin test}

The formalin test in mice was performed as described in Hunskaar \& Hole (1987). The model of formalin was performed by intraplantar injection of $10 \mu \mathrm{l}$ of a solution of $1 \%$ formalin in the right hind paw of mice. The evaluation time of the nociceptive behavior, characterized by biting or licking of the paw was observed at 5 min intervals for 50min after injection of the stimulus. The first stage was evaluated for $0-10 \mathrm{~min}$, the subsequent behavior while $(10-50 \mathrm{~min})$ was determined as the second phase.

\subsubsection{Hot Plate}


The hot plate consisted of an electrically heated surface kept at different temperatures $\left(52^{\circ} \mathrm{C}\right.$ and $\left.56^{\circ} \mathrm{C}\right)$. Mice were placed on the heated surface within Plexiglas walls to constrain their locomotion on the plate, and the latency to a discomfort reaction (licking of the paws or jumping) was recorded, with a reaction time of zero minutes signifying the start of the test. The latencies for paw licking or jumping were recorded for each animal.

\subsection{Western blot analysis}

Spinal cord were collected and homogenized in a lysis buffer containing a mixture of proteinase inhibitors and phosphatase inhibitors (Sigma). The protein concentrations of the lysate were determined using a BCA Protein Assay kit (Pierce, Rockford, IL), and $40 \mu \mathrm{g}$ of protein was loaded for each lane. Protein samples were separated on SDS-PAGE gel (8\% gradient gel; Bio-Rad, Hercules, CA) and transferred to nitrocellulose membranes (Amersham Biosciences). The filters were blocked with $5 \%$ dry milk and $2 \% \mathrm{BSA}$ and incubated overnight at $4{ }^{\circ} \mathrm{C}$ with primary antibody, anti-NOD1 1:500 (Cell Signaling), anti-NOD2 1:200 (Santa Cruz) and for 1 hr at room temperature (RT) with HRP conjugated secondary antibody (1:3000; Amersham Biosciences, Arlington Heights, IL). The blots were visualized in ECL solution (Amersham Biosciences;) for $2 \mathrm{~min}$ and exposed onto hyperfilms (Amersham Biosciences) for 1-30 min.

\subsection{Cytokine measurement}

DuoSet ELISA Development Kits (R\&D Systems, Wiesbaden, Germany) were used to determine interleukin-6 (IL-6), IL-1 $\beta$, IL-6 , tumor necrosis fator (TNF$\alpha)$ and chemokine-derived keratinocytes $(\mathrm{KC})$.

\subsection{Real-time RT-PCR}

Real-time RT-PCR was performed using the Sybr Green reagents kit and an ABI Prism 7500 sequence detection system (Applied Biosystems, Foster City, CA). The sequences of the primers used in this study are presented in table 1 . The level of 
each gene was normalized to the levels of mouse GAPDH gene and represented as fold induction. All real time RT-PCR experiments were performed at least three times.

\subsection{Immunofluorescence}

Animals were terminally anesthetized with $2 \%$ isoflurane and perfused through the ascending aorta with saline, followed by $4 \%$ paraformaldehyde in $0.1 \mathrm{M}$ phosphate buffer, $\mathrm{pH} 7.4\left(4^{\circ} \mathrm{C}\right)$. After the perfusion, spinal cord (L4-L6) were removed and postfixed in the same fixative for $2 \mathrm{hr}$ and then replaced with $30 \%$ sacarose overnight. All of the spinal cords were embedded in OCT, and sections (30 $\mu \mathrm{m})$ were cut in a cryostat and processed for immunofluorescence. All of the sections were blocked with $1 \%$ BSA in $0.3 \%$ Triton $\mathrm{X}-100$ for $1 \mathrm{hr}$ at room temperature and incubated overnight at $4^{\circ} \mathrm{C}$ with a mixture of polyclonal anti-IBA-1 1:1000 (Wako), anti-NOD1 1:50 (Santa Cruz), anti-NeuN conjugated with Alexa 488 1:500 (Millipore) antibody, followed of Alexa Fluor 488 or 594 conjugated secondary antibody for $1 \mathrm{hr}$ at room temperature. Fluorescent images were obtained with a confocal microscope (SP5, Leica, Wetzlar, Germany).

\subsection{Primary mouse microglial cell cultures}

Microglial cultures were prepared from the brains of newborn pups (1 day, P0 microglia) from C57BL/6J mice (Janvier LABS, Le Genest St Isles, France). Briefly, whole brains were harvested, meninges stripped away, then mechanically dissociated and suspended in Dulbecco's modified Eagle medium (DMEM) supplemented with $10 \%$ heat-inactivated fetal bovine serum (FBS), $100 \mathrm{U} / \mathrm{ml}$ penicillin, and $100 \mu \mathrm{g} / \mathrm{ml}$ streptomycin (Gibco). Cells were seed at a density of two brains per T75 culture flask (Corning Costar) and maintained at $37{ }^{\circ} \mathrm{C}$ in a humidified atmosphere with $5 \% \mathrm{CO}_{2}$. After 16 to 18 days of culture, microglial cells were trypsinized and the cell suspension was centrifuged $\left(1000 \mathrm{~g}, 5 \mathrm{~min}, 4{ }^{\circ} \mathrm{C}\right)$ and plated in 48 -well plates at a density of $10^{5}$ cells/well in complete medium until stimulation.

\subsection{Microglial stimulation}


Primary microglial cells were stimulated with LPS $(0,1 \mathrm{ng} / \mathrm{mL})$, MDP $(3 \mu \mathrm{g}$ $/ \mathrm{mL})$ and iE-DAP (100ng/mL). After 48 hours of stimulation, supernatants were collected and subjected to analytical profile of the release of pro-inflammatory cytokines by ELISA.

\subsection{Statistical analysis}

All data are presented as means \pm SEM. One-way ANOVA followed by Bonferroni's t-test was performed and differences were considered to be statistically significant at $P<0.05$.

\section{Results}

\subsection{NOD1 and NOD2 are expressed in the spinal cord}

First, to determine the expression profile of NOD1 and NOD2 receptors after induction of peripheral neuropathy, wildtype mice (WT) underwent SNI surgery and the spinal cord (L4, L5 and L6) of these animals collected at different times. We observed by Western blotting a significant increase in NOD1 expression at 7th and 10th days after surgery, when compared to sham. Unlike this, there was no significant increase in expression of NOD2 over days after induction of peripheral neuropathy when compared to the sham control group (Fig. 1), suggesting the constitutive expression of this receptor in the spinal cord. The same results for NOD1 and NOD2 were observed by RT-PCR Fig supplementary 1.

To identify the cell type that expresses NOD1 receptor, spinal cord of WT and $\mathrm{NOD}^{-/-}$were collected at peak NOD1 expression, on the tenth day, for analysis by double staining immunofluorescence technique using a NOD1 marker and specific marker of neuronal nuclei $(\mathrm{NeuN})$. Following peripheral nerve injury, a strong activation of NOD1 (red marker) was observed in the ipsilateral side of the WT mice (Fig. 2A panel b), different from Sham animals, where only a discrete marking NOD1 was seen (Fig. 2A panel a). In $\mathrm{NOD}^{-/-}$mice was not observed activation NOD1, confirming the specificity of the antibody tested (Fig 2A panel c). Regarding the NeuN (green marker), all tested groups showed neuronal labeling. In addition, it was shown that the positive cells for NOD1 co-located with cells that express neuronal 
labeling suggesting that after peripheral neuropathy, the NOD1 receptors are expressed in neurons in spinal cord (Fig. 2B panel b).

\subsection{NOD1 and NOD2, via RIPK2, contribute to the induction of pain hypersensitivity after peripheral nerve injury}

We then tested the susceptibility of the NOD $1^{-/}$, NOD2 ${ }^{-/-}$and RIPK $2^{-/-}$male mice to nerve injury-induced pain hypersensitivity. Upon SNI surgery, wild-type mice showed increased sensitivity to mechanical stimuli (Fig. 3). The paw withdrawal threshold to the mechanical stimuli decreased 3 day after nerve injury, and, after 14 days, was reduced to 1,69 $\pm 0,13 \log \mathrm{mg}$, compared with the original threshold before transection $(3,00 \pm 0.00 \log \mathrm{mg})$. The paw withdrawal threshold of the $\mathrm{NOD} 1^{-/-}$mice, however, reduced only to $2,71 \pm 0,09 \log \mathrm{mg}$ (Fig. $3 \mathrm{~A}$ ), NOD2 $2^{-/-}$to $2,75 \pm 0,14 \log$ mg (Fig. 3B) and RIPK2 ${ }^{--}$to $2,55 \pm 0,21 \log \mathrm{mg}$ (Fig. 3C) compared with their respective original threshold $\left(3,00 \pm 0,00 \log \mathrm{mg}\right.$ for $\mathrm{NOD}^{-/-} ; 3,02 \pm 0,05 \log \mathrm{mg}$ for $\mathrm{NOD}^{-{ }^{-}}$and 2,91 $\pm 0,12 \log \mathrm{mg}$ for RIPK2 ${ }^{-/-}$). Pain hypersensitivity was not observed in the sham-operated wild-type. These data indicate that NOD1 and NOD2, via RIPK2, is required for the maximum induction of mechanical allodynia upon peripheral nerve injury. We also tested the susceptibility of the $\mathrm{NOD}^{-{ }^{-}}, \mathrm{NOD}^{-\gamma_{-}}$and $\mathrm{RIPK}^{-/-}$female mice to nerve injury-induced pain hypersensitivity. It was shown that these female mice displayed significantly attenuated mechanical allodynia compared with their respective WT controls for the days 5-21 after the surgery likewise male mice (Supplementary 2).

\subsection{NOD1 and NOD2, via RIPK2, are not involved in the induction of inflammatory pain}

Peripheral administration of CFA caused a reduction in the paw withdrawal threshold to mechanical stimuli in WT, $\mathrm{NOD}^{-/-}, \mathrm{NOD}^{-/-}$and $\mathrm{RIPK}^{-{ }^{--}}$male mice groups. The paw withdrawal threshold to mechanical stimuli was significantly different between the CFA and saline-treated mice in the ipsilateral hind paw. The WT-CFA group reaches the lowest threshold at 3th day after peripheral administration of CFA $(1,49 \pm 0,22 \log \mathrm{mg})$, compared with the original threshold before CFA administration $(2,81 \pm 0,09 \log \mathrm{mg})$. The paw withdrawal threshold of the NOD1 ${ }^{-/}$- 
CFA mice reduced to $1,86 \pm 0,40 \log \mathrm{mg}$ (Fig. 4A), NOD2 ${ }^{-/}$-CFA to $1,74 \pm 0,13 \log$ mg (Fig. 4B) and RIPK2 ${ }^{-/-}$-CFA to $1,81 \pm 0,24 \log \mathrm{mg}$ (Fig. 4C) compared with their respective original threshold $\left(2,82 \pm 0,09 \log \mathrm{mg}\right.$ for NOD1 $1^{-/-}$CFA ; 2,82 $\pm 0,09 \log$ $\mathrm{mg}$ for $\mathrm{NOD}^{-/-}$-CFA and 2,82 $\pm 0,09 \log \mathrm{mg}$ for RIPK2 ${ }^{-{ }^{-}}$-CFA ). The paw withdrawal threshold in both hind paws in the saline-treated mice remained stable over the observation period.

\subsection{NOD1 ${ }^{-/}$, NOD2 $2^{-/-}$and RIPK2 ${ }^{-/-}$respond normally to nociceptive stimuli}

Once observed that NOD1 and NOD2 contribute to pain hypersensitivity after induction of peripheral neuropathy, but not participate in the inflammatory pain process induced by intraplantar administration of CFA, next we determinate the role of these receptors in thermal and chemical nociception models. First, we investigated the NOD1 and NOD2 participation in Hot Plate. This test produces two behavioral components, both supraspinal considered integrated responses that can be measured in terms of their reaction times, ie paw licking and jumping. The latency to the appearance of such responses, timed in seconds, is considered indicative of the intensity of the nociceptive response to thermal stimulus (Yaksh \& Rudy, 1976, 1977; Yeung et al., 1977). As a result, NOD $1^{-/-}$, NOD2 $2^{-/-}$and RIPK2 $2^{-/-}$had no significant difference in latency time when compared to the WT group (Fig.5).

Next, we investigated the NOD1 and NOD2 participation in Formalin test, that is characterized by two phases, an acute phase (first phase, lasting 0-10 min), then $2^{\text {nd }}$ phase consisting of a longer time (10 - 50 min) (Hunskaar \& Hole, 1987). The initial response was attributed to a neurogenic effect of formalin in nociceptor (nociceptive phase) (Tjolsen et al., 1992), while the 2nd phase (inflammatory phase) was associated with the release of local endogenous mediators responsible for the sensitization of sensitive spinal neurons and subsequent nociception activation (Parada et al., 2011). There was no significant difference in licking time between $\mathrm{NOD}^{-{ }^{--}}, \mathrm{NOD}^{-\gamma_{-}}$and RIPK2 $2^{-/-}$and WT group (Fig. 6).

\subsection{NOD1 and NOD2, via RIPK2, are required for the nerve injury-induced spinal cord glial cell activation.}


It is well known that peripheral nerve injury induces glial cell activation in the spinal cord (Garrison et al., 1991; Svensson et al., 1993; Coyle, 1998). The activation of microglia and astrocytes in the nerve-damaged mice was tested by Real-Time RTPCR. The transcript of IBA-1 for WT group was up-regulated in the dorsal horn of nerve-damaged mice at $3^{\text {rd }}, 7^{\text {th }}, 10^{\text {th }}$ and $14^{\text {th }}$ days (Fig. 7). As expected, the induction levels of this gene were reduced in the NOD $1^{-/-}, \mathrm{NOD}^{-/-}$and RIPK $2^{-/-}$at $7^{\text {th }}, 10^{\text {th }}$ and $14^{\text {th }}$ days after the peripheral nerve injury. We detect a low induction of of IBA-1 in the sham-operated wild-type mice, indicating that the upregulation of this gene in the spinal cord dorsal horn was due directly to the nerve injury. Also, the activation of microglia in the nerve-damaged mice was tested by immunostaining with anti-IBA-1 antibody. Upon nerve injury, strong activation of microglia was observed in the ipsilateral dorsal horn on day 10 . However, this activation was significantly decreased in $\mathrm{NOD}^{-/-}$, NOD2 $2^{-/-}$and RIPK2 ${ }^{-/-}$(Fig. 8).

Moreover, the spinal nerve injury-induced GFAP expression in the dorsal horn for WT group was up-regulated only at $7^{\text {th }}$ day and the induction levels of this gene were reduced in the NOD $1^{-/-}$, NOD2 $2^{-/-}$and RIPK2 $2^{-/}$at this point day (Fig. 9).

\subsection{NOD1 and NOD2, via RIPK2, are required for the nerve injury-induced pro-inflammatory cytokines expression.}

The induction of pain-mediating gene expression in the spinal cord was also measured by ELISA upon peripheral nerve injury. The levels of IL- $1 \beta$ and TNF- $\alpha$ for WT group was up-regulated in the dorsal horn of nerve-damaged mice at 7 th day. As expected, the induction levels of these cytokines were reduced in the $\mathrm{NOD}^{-{ }^{-}}$, NOD2 ${ }^{-}$ /- and RIPK2 ${ }^{-/-}$at this day, after the peripheral nerve injury (Fig. 10). Taken together, these data show that NOD1 and NOD2 are required for the nerve injury-induced painmediating inflammatory gene expression in the spinal cord in vivo.

\subsection{The synergistic effect of MDP with LPS enhances the microglial release of pro-inflammatory cytokines}

Microglia are a major source of cytokines and chemokines important for eliciting and regulating the immune response (Hanisch, 2002). Thus, we investigated the cytokines expression pattern induced in microglia in response to co-stimulation of 
MDP or iE-DAP with a sub-maximal concentration of LPS $(0,1 \mathrm{ng} / \mathrm{mL})$. As a result, it was observed that iE-DAP and MDP alone or control cultures receiving medium did not reveal any cytokine release and LPS alone generates a mild induction in the release of cytokines. The co-stimulation of iE-DAP and LPS was unable to increase levels of pro-inflammatory cytokines released when compared with the group stimulated with only $0,1 \mathrm{ng} / \mathrm{mL}$ LPS (Fig. 11). However, unlike what was observed for NOD1, the co-incubation of MDP and LPS induced a robust response characterized by increased production of proinflammatory cytokines compared with the group that was not stimulated (Fig. 12). Importantly, it was not detected measurable levels of IL$1 \beta$ cytokine in both tested stimuli alone (MDP and iE-DAP) and combinations used with LPS.

\subsection{NOD1 and NOD2, via RIPK2, contribute to the P2X4 expression after induction of peripheral nerve injury}

Recent findings suggest that activation of $\mathrm{P} 2 \mathrm{X} 4$, expressed in microglia, contributes to the development of neuropathic pain (Coull et al., 2005). Furthermore, it was demonstrated that TLRs and NLRs cooperate in microglia activation leading to increased expression of P2X4 and consequently cytokines release (Guo et al., 2006). Based on this, next we evaluate the involvement of NOD1 and NOD2 in P2X4 activation during the process peripheral neuropathy by Real-Time RT-PCR. The transcript of P2X4 for WT group was upregulated in the dorsal horn of nervedamaged mice at $7^{\text {th }}, 10^{\text {th }}$ and $14^{\text {th }}$ days (Fig. 13). However, P2X4 was reduced in the $\mathrm{NOD}^{-/-}$, NOD $2^{-/-}$and RIPK $2^{-/-}$only at $14^{\text {th }}$ day after the peripheral nerve injury. This result suggests a role of these receptors in P2X4 activation during the development of neuropathy process.

\section{Discussion}

There are approximately 15 years ago, NOD1 and NOD2 receptors were first described. After recognizing bacterial products, these receptors are associated with RIPK2 via CARD-CARD homophilic interaction, leading to the activation of NF-kB and transcription of several regulatory genes (Ogura et al., 2001a). The physiological role of NLRs can be summarized as host defense against bacterial infections, and, 
disrupting the function of these receptors, such as the association between CARD15 mutations in the NOD2 gene encoding, is related to the development of chronic inflammatory disorders, as Crohn's disease (Ogura et al, 2001b; Hugot et al, 2001), Blau syndrome (Richard-Miceli et al., 2001; Wang et al., 2002), autoimmunity and cancer predisposition (Aries et al, 2008;. Davis et al, 2011). Since then, research on these receptors is mainly focused on its role in immune and inflammatory response.

Although Sato and colleagues (2011) have shown that NOD2 is important for the analgesic activity by reducing the frequency of writhing induced by acetic acid, more recently, the involvement of this receptor in inflammatory joint pain (arthritis model induced antigen was identified in mice), which is the first study to correlate the role of NOD2 in a pro-nociceptive context (Vieira et al., 2012). However, little is known about the participation of NOD1 and NOD2 in the development of painful process.

Several mechanisms have been proposed to explain the genesis of chronic pain. What essentially is believed that during tissue injury processes, inflammatory or nervous, constant stimulation of nociceptive pathways leads to an intense release excitatory neurotransmitter in the spinal cord, which causes thermal hyperalgesia and cold allodynia, but changes are not observed in the thermal heat baseline threshold, similarly to what occurs in humans with neuropathic pain (Woolf \& Mannion, 1999).

Given this evidence, we first verified the contribution of NOD1, NOD2 and RIPK2 to hypersensitivity to pain after induction of peripheral neuropathy, and it was observed that the deficient mice showed a significant reduction of mechanical hyperalgesia, compared with the respective WT control group, at the fifth to twentyfirst day after surgery, suggesting that NOD1 and NOD2, via RIPK2, contribute to the mechanical hyperalgesia after induction of peripheral neuropathy in the same way that some TLRs.

It has been reported in the literature that acute peripheral inflammation and injury to peripheral nerves neuroinflammatory produce distinct reactions in the spinal cord (Sweitzer et al., 1999). The intraplantar administration inflammatory stimuli, such as formalin or zymozan produce soft microglial activation in the spinal cord, in contrast to a strong activation after induction of peripheral neuropathy. However, Raghavendra and colleagues (2004) demonstrated that peripheral inflammation induced by CFA was able to produce mechanical and thermal hyperalgesia, which began in the fourth hour after CFA administration, and maintained until the last day of 
assessment, on the fourteenth day. Moreover, this model has been shown to induce glial cell activation, such as microglia and astrocytes, and release of pro-inflammatory cytokines in the same pattern observed after induction of peripheral neuropathy (Thong et al., 2004).

CFA is comprised of an oil in water emulsion containing inactivated mycobacteria by heat action or their cell wall components. It is able to induce a strong inflammatory response, persistent pain and edema, and is effective in enhancing humoral and cellular immune response. After the intraplantar CFA injection in mice, skin inflammation appears within a few hours, with peaks within 5-8 hours post application (Millan et al., 1988). The peak in the formation of edema is observed in about 24 hours, whereas the induction of hyperalgesia and allodynia characteristic is already in the fifth hour after application and persists for about one to two weeks (Lao et al., 2004).

Thus, we also investigated the role of NOD1 and NOD2 in the development of inflammatory pain by intraplantar administration of CFA. As a result of the mechanical nociceptive evaluation, it was observed that both WT or knock out mice for NOD1, NOD2 and RIPK2 presented mechanical hyperalgesia during the 21 days tested, suggesting that the receptors do not participate in the inflammatory pain development. Furthermore, mice deficient for NOD1, NOD2 and RIPK2 responded normally to different noxious stimuli, in the same way as WT mice, pointing again to only the role of these receptors in the process of developing the neuropathic pain.

A property of experimental and clinical neuropathic pain is central sensitization phenomenon identified particularly with the reduction of nociceptive threshold and increased responsiveness of dorsal horn neurons of the spinal cord to various stimuli (Woolf, 2011). Thus, the sensitized neurons allow that not noxious stimuli cause pain (allodynia) and facilitate the transmission of painful stimuli previously, or painful sensation is intensified (hyperalgesia / hypernociception) (Ji et al., 2003). Central sensitization occurs due to repeated stimulation of nociceptors and due to plastic changes in neurons and glial cells.

The results of our study demonstrated through different techniques that NOD1 ${ }_{--}^{-}, \mathrm{NOD}^{-/-}$and RIPK2 $2^{-/-}$mice exhibit a significant reduction in the IBA-1 expression in the seventh, tenth and fourteenth day, and GFAP only on the seventh day, thus suggesting contribution of both receptors on glial cells activation. These results are consistent with previous reports demonstrating the role of some TLRs in induction 
and maintenance of neuropathic pain. Thong et al (2005) demonstrated that TLR4 deficient mice show a reduction in neuropathic chronic pain and astrocytes and microglia activation in the third, seventh and fourteenth day, when compared with WT mice after peripheral neuropathy induced by nerve ligation model spinal. Using this same model of neuropathy was also demonstrated that TLR2 deficient mice also reduce the mechanical hyperalgesia and astroglial and microglial activation in the fourth and seventh post- surgery (Kim et al., 2007).

As mentioned, one possible mechanism by which glial cells induce hyperalgesia and allodynia is through release of proinflammatory cytokines such as IL-1 $\beta$, TNF- $\alpha$ and IL-6 (Milligan \& Watkins, 2009). These cytokines are often released in cascade, where the initial release of TNF- $\alpha$ is followed by IL-1 $\beta$ and subsequently, IL-6 (Wieseler-Frank et al., 2005). In fact, the IL-6 intrathecal administration produces allodynia to touch, in normal rats (Deleo et al., 1996), similarly, intrathecal administration of IL-1 $\beta$ also leads to the development of mechanical hyperalgesia and allodynia and contributes to increased neuronal excitability (Reeve et al., 2000). It should be emphasized that the use of different experimental models for the study of pain could show different activity patterns across the intensity of each stimulus, in which the cytokines can act synergistically, or act sequentially (Cunha et al., 2005) or can form a complex network of interdependent activation.

Our results suggest that NOD1 and NOD2, via RIPK2, also participate in the induction of pro-nociceptive cytokines in spinal cord during the process of neuropathic pain, since it was observed decreased production of IL-1 $\beta$ and TNF- $\alpha$ in deficient mice compared to WT group.

Continuing to work, the next step was to evaluate the induction profile of these cytokines in primary microglia cells cultures stimulated by NOD1, NOD2 and TLR4 agonists or by their co-administration. Thus, it was observed that the MDP alone is unable to generate a response and LPS at a concentration of $0,1 \mathrm{ng} / \mathrm{mL}$ generates a mild induction in the release of cytokines. However, the co-stimulation of both (MDP + LPS) induced a robust response characterized by high production of pro-inflammatory cytokines, corroborating data from the literature. Sterka \& Marriott (2006) showed that primary microglia cultures expresse constitutive levels of NOD2 and that this expression is increased upon exposure to Gram-negative bacteria, MDP and specific ligands of TLR4 (LPS) and TLR5 (flagellin) receptors. Still, several 
studies have shown that the MDP acts synergistically with TLRs agonists in microglia, triggering a high inflammatory response including an increase in the release of pro-inflammatory cytokines and nitric oxide (NO) (Chauhan et al, 2009; \& Sterka Marriott, 2006; Kinsner et al., 2006; Ribes et al, 2012.).

Although this synergism can be explained by various mechanisms, the simplest interpretation suggests that binding of LPS to TLR4 increases the expression of NOD2, which can then associate in the presence of MDP, to trigger the activation of NF-kB and production of inflammatory cytokines much more efficiently than just the activation of TLR4 alone. Similarly, due to relatively low expression of NOD2 in the absence of TLR ligands, MDP alone would be less effective action (Sterka \& Marriott, 2006). Another study indicates a possible link between TLRs, NOD2 and purinergic mechanisms of inflammation in the CNS. The authors suggest that the synergistic effect of MDP and TLRs ligands leads to microglial activation, inducing additive effects on the production of NO and TNF and increasing the expression of P2X4 (Guo et al., 2006). Moreover, Chauhan et al (2009) showed that MDP, when administered jointly with LPS or flagellin does not induce increased production of proinflammatory cytokines in microglial cultures derived from mice deficient in NOD2, thus confirming the specific action MDP in NOD2 receptors.

Moreover, Sterka and Marriott (2006) showed that primary cultures of microglia express very low (or sometimes do not express) the constitutive levels NOD1 and only modest levels after exposure to bacteria. In our study, we observed that the $\mathrm{iE}-\mathrm{DAP}$ alone is unable to generate a response and that the co-administration with LPS, was not able to increase the levels of pro-inflammatory cytokines released. In contrast, this synergism is observed in other types of cultures, such as macrophages (CHAMAILLARD et al., 2003) and peripheral blood mononuclear cells (Van Heel et al., 2005). It was recently demonstrated by Zheng et al. (2012) that LPS can activate microglia cultures and to induce the production of proinflammatory cytokines acting in two ways. The first would be dependent on TLR4 and mitogen-activated protein kinases (MAPKs), type c-Jun N-terminal (JNK). The other way would be dependent NOD1 and NF-kB.

The time course of activation of glial cells as well as increased expression of proinflammatory cytokines are closely related to the development of chronic pain (Raghavendra et al., 2004). Even after a peripheral nerve injury, activated microglia leads to expression of the $\mathrm{P} 2 \mathrm{X} 4$ receptor, which is also involved in the pathogenesis 
of neuropathic pain by release of brain-derived neurotrophic factor (BDNF), which then acts on neurons in the dorsal horn thus inducing spinal hyperexcitability (Coull et al., 2005). Furthermore, it also been demonstrated that TLRs and NLRs receptors cooperate in microglia activation leading to increased expression of P2X4 and consequently cytokines release (Guo et al., 2006). Based on this evidence, we demonstrate a significant reduction in P2X4 expression in $\mathrm{NOD}^{-/-}, \mathrm{NOD} 2^{-/-}$and $\mathrm{RIPK}^{-/-}$mice, on the 14th day after nerve injury, when compared to WT, suggesting a role of NOD1 and NOD2 in activate these ATP receptors during the neuropathic pain process.

\section{Conclusion}

The results suggest that NOD1 and NOD2, via RIPK2, contribute to the genesis of neuropathic pain, possibly by mediating the release of pronociceptive cytokines and increased glial cells activation. Moreover, it seems that NOD2 activation seems to synergy with TLR4 in attempt to stimulate glial cells activation. These mechanisms represent a novel approach for elucidating the pathophysiology of chronic pain, and a target for the development of drugs for the treatment of neuropathic pain

\section{Conflicts of interest}

The authors have no conflicts of interest.

\section{Acknowledgments}

We thank the excellent technical assistance of Ieda Regina dos Santos Schivo, Sérgio Roberto Rosa, Eleni Luiza Tamburus Gomes and Elizabete Rosa. This work was supported by grants from FAPESP, CAPES, Pronex and CNPq (Brazil).

\section{References}


Abbott DW, Wilkins A, Asara JM, Cantley LC, 2004. The Crohn's disease protein, NOD2, requires RIP2 in order to induce ubiquitinylation of a novel site on NEMO. Curr Biol14, 2217-27.

Akira S, 2009. Pathogen recognition by innate immunity and its signaling. Proc Jpn Acad Ser B Phys Biol Sci85, 143-56.

Asea A, Rehli M, Kabingu E, et al., 2002. Novel signal transduction pathway utilized by extracellular HSP70: role of toll-like receptor (TLR) 2 and TLR4. J Biol Chem277, 15028-34.

Austin PJ, Moalem-Taylor G, 2010. The neuro-immune balance in neuropathic pain: involvement of inflammatory immune cells, immune-like glial cells and cytokines. $J$ Neuroimmunol229, 26-50.

Barnich N, Aguirre JE, Reinecker HC, Xavier R, Podolsky DK, 2005. Membrane recruitment of NOD2 in intestinal epithelial cells is essential for nuclear factor\{kappa\}B activation in muramyl dipeptide recognition. J Cell Biol170, 21-6.

Baron R, Binder A, 2004. [How neuropathic is sciatica? The mixed pain concept]. Orthopade33, 568-75.

Basbaum AI, Bautista DM, Scherrer G, Julius D, 2009. Cellular and molecular mechanisms of pain. Cell139, 267-84.

Beggs S, Salter MW, 2007. Stereological and somatotopic analysis of the spinal microglial response to peripheral nerve injury. Brain Behav Immun21, 624-33.

Benveniste EN, Tang LP, Law RM, 1995. Differential regulation of astrocyte TNFalpha expression by the cytokines TGF-beta, IL-6 and IL-10. Int J Dev Neurosci13, 341-9.

Bianchi ME, 2007. DAMPs, PAMPs and alarmins: all we need to know about danger. J Leukoc Biol81, 1-5.

Burnstock G, 2006. Pathophysiology and therapeutic potential of purinergic signaling. Pharmacol Rev58, 58-86.

Calvo M, Bennett DL, 2012. The mechanisms of microgliosis and pain following peripheral nerve injury. Exp Neurol234, 271-82.

Cao L, Tanga FY, Deleo JA, 2009. The contributing role of CD14 in toll-like receptor 4 dependent neuropathic pain. Neuroscience 158, 896-903.

Carneiro LA, Magalhaes JG, Tattoli I, Philpott DJ, Travassos LH, 2008. Nod-like proteins in inflammation and disease. J Pathol214, 136-48.

Carpentier PA, Duncan DS, Miller SD, 2008. Glial toll-like receptor signaling in central nervous system infection and autoimmunity. Brain Behav Immun22, 140-7. 
Caruso R, Warner N, Inohara N, Nunez G, 2014. NOD1 and NOD2: signaling, host defense, and inflammatory disease. Immunity41, 898-908.

Chamaillard M, Hashimoto M, Horie Y, et al., 2003. An essential role for NOD1 in host recognition of bacterial peptidoglycan containing diaminopimelic acid. Nat Immunol4, 702-7.

Chauhan VS, Sterka DG, Jr., Furr SR, Young AB, Marriott I, 2009. NOD2 plays an important role in the inflammatory responses of microglia and astrocytes to bacterial CNS pathogens. Glia57, 414-23.

Chen G, Shaw MH, Kim YG, Nunez G, 2009. NOD-like receptors: role in innate immunity and inflammatory disease. Annu Rev Pathol4, 365-98.

Chisholm ST, Coaker G, Day B, Staskawicz BJ, 2006. Host-microbe interactions: shaping the evolution of the plant immune response. Cell124, 803-14.

Clark AK, Gentry C, Bradbury EJ, Mcmahon SB, Malcangio M, 2007. Role of spinal microglia in rat models of peripheral nerve injury and inflammation. Eur J Pain11, 223-30.

Clark AK, Yip PK, Malcangio M, 2009. The liberation of fractalkine in the dorsal horn requires microglial cathepsin S. J Neurosci29, 6945-54.

Colburn RW, Deleo JA, Rickman AJ, Yeager MP, Kwon P, Hickey WF, 1997. Dissociation of microglial activation and neuropathic pain behaviors following peripheral nerve injury in the rat. J Neuroimmunol79, 163-75.

Colburn RW, Rickman AJ, Deleo JA, 1999. The effect of site and type of nerve injury on spinal glial activation and neuropathic pain behavior. Exp Neurol157, 289-304.

Costigan M, Mannion RJ, Kendall G, et al., 1998. Heat shock protein 27: developmental regulation and expression after peripheral nerve injury. J Neurosci18, 5891-900.

Costigan M, Moss A, Latremoliere A, et al., 2009. T-cell infiltration and signaling in the adult dorsal spinal cord is a major contributor to neuropathic pain-like hypersensitivity. J Neurosci29, 14415-22.

Coull JA, Beggs S, Boudreau D, et al., 2005. BDNF from microglia causes the shift in neuronal anion gradient underlying neuropathic pain. Nature438, 1017-21.

Coutaux A, Adam F, Willer JC, Le Bars D, 2005. Hyperalgesia and allodynia: peripheral mechanisms. Joint Bone Spine72, 359-71.

Coyle DE, 1998. Partial peripheral nerve injury leads to activation of astroglia and microglia which parallels the development of allodynic behavior. Glia 23, 75-83. 
Cunha TM, Verri WA, Jr., Silva JS, Poole S, Cunha FQ, Ferreira SH, 2005. A cascade of cytokines mediates mechanical inflammatory hypernociception in mice. Proc Natl Acad Sci U S A102, 1755-60.

Cunha TM, Verri WA, Jr., Vivancos GG, et al., 2004. An electronic pressure-meter nociception paw test for mice. Braz J Med Biol Res37, 401-7.

Davis BK, Wen H, Ting JP, 2011. The inflammasome NLRs in immunity, inflammation, and associated diseases. Annu Rev Immunol29, 707-35.

Decosterd I, Woolf CJ, 2000. Spared nerve injury: an animal model of persistent peripheral neuropathic pain. Pain87, 149-58.

Deleo JA, Colburn RW, Nichols M, Malhotra A, 1996. Interleukin-6-mediated hyperalgesia/allodynia and increased spinal IL-6 expression in a rat mononeuropathy model. J Interferon Cytokine Res16, 695-700.

Deleo JA, Yezierski RP, 2001. The role of neuroinflammation and neuroimmune activation in persistent pain. Pain90, 1-6.

Dworkin RH, O'connor AB, Audette J, et al., 2010. Recommendations for the pharmacological management of neuropathic pain: an overview and literature update. Mayo Clin Proc85, S3-14.

Eriksson NP, Persson JK, Svensson M, Arvidsson J, Molander C, Aldskogius H, 1993. A quantitative analysis of the microglial cell reaction in central primary sensory projection territories following peripheral nerve injury in the adult rat. Exp Brain Res96, 19-27.

Girardin SE, Boneca IG, Carneiro LA, et al., 2003a. Nod1 detects a unique muropeptide from gram-negative bacterial peptidoglycan. Science300, 1584-7.

Girardin SE, Boneca IG, Viala J, et al., 2003b. Nod2 is a general sensor of peptidoglycan through muramyl dipeptide (MDP) detection. J Biol Chem278, 886972 .

Gosselin RD, Suter MR, Ji RR, Decosterd I, 2010. Glial cells and chronic pain. Neuroscientist16, 519-31.

Grace PM, Hutchinson MR, Maier SF, Watkins LR, 2014. Pathological pain and the neuroimmune interface. Nat Rev Immunol14, 217-31.

Guo LH, Guo KT, Wendel HP, Schluesener HJ, 2006. Combinations of TLR and NOD2 ligands stimulate rat microglial P2X4R expression. Biochem Biophys Res Commun349, 1156-62.

Hasegawa M, Yang K, Hashimoto M, et al., 2006. Differential release and distribution of Nod1 and Nod2 immunostimulatory molecules among bacterial species and environments. J Biol Chem281, 29054-63. 
Hisamatsu T, Suzuki M, Reinecker HC, Nadeau WJ, Mccormick BA, Podolsky DK, 2003. CARD15/NOD2 functions as an antibacterial factor in human intestinal epithelial cells. Gastroenterology124, 993-1000.

Hugot JP, Chamaillard M, Zouali H, et al., 2001. Association of NOD2 leucine-rich repeat variants with susceptibility to Crohn's disease. Nature411, 599-603.

Hunskaar S, Hole K, 1987. The formalin test in mice: dissociation between inflammatory and non-inflammatory pain. Pain30, 103-14.

Hutchinson MR, Ramos KM, Loram LC, et al., 2009. Evidence for a role of heat shock protein-90 in toll like receptor 4 mediated pain enhancement in rats. Neuroscience 164, 1821-32.

Inohara, Chamaillard, Mcdonald C, Nunez G, 2005. NOD-LRR proteins: role in hostmicrobial interactions and inflammatory disease. Annu Rev Biochem74, 355-83.

Inohara N, Koseki T, Del Peso L, et al., 1999. Nod1, an Apaf-1-like activator of caspase-9 and nuclear factor-kappaB. J Biol Chem274, 14560-7.

Inohara N, Koseki T, Lin J, et al., 2000. An induced proximity model for NF-kappa B activation in the Nod1/RICK and RIP signaling pathways. J Biol Chem275, 27823-31.

Inohara N, Ogura Y, Fontalba A, et al., 2003. Host recognition of bacterial muramyl dipeptide mediated through NOD2. Implications for Crohn's disease. J Biol Chem 278, 5509-12.

Inoue K, 2002. Microglial activation by purines and pyrimidines. Glia40, 156-63.

Inoue K, Tsuda M, 2006. [The role of microglia and ATP receptors in a mechanism of neuropathic pain]. Nihon Yakurigaku Zasshi127, 14-7.

Inoue K, Tsuda M, 2012. Purinergic systems, neuropathic pain and the role of microglia. Exp Neurol234, 293-301.

Isami K, Haraguchi K, So K, et al., 2013. Involvement of TRPM2 in peripheral nerve injury-induced infiltration of peripheral immune cells into the spinal cord in mouse neuropathic pain model. PLoS One8, e66410.

Ji RR, Xu ZZ, Gao YJ, 2014. Emerging targets in neuroinflammation-driven chronic pain. Nat Rev Drug Discov13, 533-48.

Jin SX, Zhuang ZY, Woolf CJ, Ji RR, 2003. p38 mitogen-activated protein kinase is activated after a spinal nerve ligation in spinal cord microglia and dorsal root ganglion neurons and contributes to the generation of neuropathic pain. J Neurosci23, 4017-22.

Johannes CB, Le TK, Zhou X, Johnston JA, Dworkin RH, 2010. The prevalence of chronic pain in United States adults: results of an Internet-based survey. J Pain11, 1230-9. 
Julius D, Basbaum AI, 2001. Molecular mechanisms of nociception. Nature413, 20310 .

Kalso E, Edwards JE, Moore RA, Mcquay HJ, 2004. Opioids in chronic non-cancer pain: systematic review of efficacy and safety. Pain112, 372-80.

Kandel ER, Schwartz JH, Jessel TM, 2000. The perception of pain. In: Principles of neural science, $4^{\mathrm{a}}$ ed. EUA : MacGraw-Hill, cap. 24, 472-91.

Kawai T, Akira S, 2010. The role of pattern-recognition receptors in innate immunity: update on Toll-like receptors. Nat Immunol11, 373-84.

Kawasaki Y, Xu ZZ, Wang X, et al., 2008. Distinct roles of matrix metalloproteases in the early- and late-phase development of neuropathic pain. Nat Med14, 331-6.

Kim D, Kim MA, Cho IH, et al., 2007. A critical role of toll-like receptor 2 in nerve injury-induced spinal cord glial cell activation and pain hypersensitivity. $J$ Biol Chem282, 14975-83.

Kim DS, Figueroa KW, Li KW, Boroujerdi A, Yolo T, Luo ZD, 2009. Profiling of dynamically changed gene expression in dorsal root ganglia post peripheral nerve injury and a critical role of injury-induced glial fibrillary acidic protein in maintenance of pain behaviors [corrected]. Pain143, 114-22.

Kinsner A, Boveri M, Hareng L, et al., 2006. Highly purified lipoteichoic acid induced pro-inflammatory signalling in primary culture of rat microglia through Tolllike receptor 2: selective potentiation of nitric oxide production by muramyl dipeptide. J Neurochem99, 596-607.

Kobayashi K, Inohara N, Hernandez LD, et al., 2002. RICK/Rip2/CARDIAK mediates signalling for receptors of the innate and adaptive immune systems. Nature416, 194-9.

Kuang X, Huang Y, Gu HF, et al., 2012. Effects of intrathecal epigallocatechin gallate, an inhibitor of Toll-like receptor 4, on chronic neuropathic pain in rats. Eur $J$ Pharmacol676, 51-6.

Kufer TA, Kremmer E, Adam AC, Philpott DJ, Sansonetti PJ, 2008. The patternrecognition molecule Nod1 is localized at the plasma membrane at sites of bacterial interaction. Cell Microbiol10, 477-86.

Kumar H, Kawai T, Akira S, 2011. Pathogen recognition by the innate immune system. Int Rev Immunol30, 16-34.

Kuraishi Y, Harada Y, Aratani S, Satoh M, Takagi H, 1983. Separate involvement of the spinal noradrenergic and serotonergic systems in morphine analgesia: the differences in mechanical and thermal algesic tests. Brain Res273, 245-52. 
Land WG, 2015. The Role of Damage-Associated Molecular Patterns in Human Diseases: Part I - Promoting inflammation and immunity. Sultan Qaboos Univ Med J15, e9-e21.

Lao L, Zhang RX, Zhang G, Wang X, Berman BM, Ren K, 2004. A parametric study of electroacupuncture on persistent hyperalgesia and Fos protein expression in rats. Brain Res1020, 18-29.

Ledeboer A, Gamanos M, Lai W, et al., 2005. Involvement of spinal cord nuclear factor kappaB activation in rat models of proinflammatory cytokine-mediated pain facilitation. Eur J Neurosci22, 1977-86.

Liu X, Chauhan VS, Marriott I, 2010a. NOD2 contributes to the inflammatory responses of primary murine microglia and astrocytes to Staphylococcus aureus. Neurosci Lett474, 93-8.

Liu X, Chauhan VS, Young AB, Marriott I, 2010b. NOD2 mediates inflammatory responses of primary murine glia to Streptococcus pneumoniae. Glia58, 839-47.

Loeser JD, Melzack R, 1999. Pain: an overview. Lancet353, 1607-9.

Manjavachi MN, Costa R, Quintao NL, Calixto JB, 2014. The role of keratinocytederived chemokine (KC) on hyperalgesia caused by peripheral nerve injury in mice. Neuropharmacology79, 17-27.

Marchand F, Tsantoulas C, Singh D, et al., 2009. Effects of Etanercept and Minocycline in a rat model of spinal cord injury. Eur J Pain13, 673-81.

Marriott I, Rati DM, Mccall SH, Tranguch SL, 2005. Induction of Nod1 and Nod2 intracellular pattern recognition receptors in murine osteoblasts following bacterial challenge. Infect Immun73, 2967-73.

Meller ST, Dykstra C, Grzybycki D, Murphy S, Gebhart GF, 1994. The possible role of glia in nociceptive processing and hyperalgesia in the spinal cord of the rat. Neuropharmacology33, 1471-8.

Meylan E, Tschopp J, Karin M, 2006. Intracellular pattern recognition receptors in the host response. Nature442, 39-44.

Miceli-Richard C, Lesage S, Rybojad M, et al., 2001. CARD15 mutations in Blau syndrome. Nat Genet29, 19-20.

Mika J, Zychowska M, Popiolek-Barczyk K, Rojewska E, Przewlocka B, 2013. Importance of glial activation in neuropathic pain. Eur J Pharmacol716, 106-19.

Millan MJ, Czlonkowski A, Morris B, et al., 1988. Inflammation of the hind limb as a model of unilateral, localized pain: influence on multiple opioid systems in the spinal cord of the rat. Pain35, 299-312. 
Milligan ED, O'connor KA, Nguyen KT, et al., 2001. Intrathecal HIV-1 envelope glycoprotein gp120 induces enhanced pain states mediated by spinal cord proinflammatory cytokines. J Neurosci21, 2808-19.

Milligan ED, Watkins LR, 2009. Pathological and protective roles of glia in chronic pain. Nat Rev Neurosci10, 23-36.

Milligan ED, Zapata V, Chacur M, et al., 2004. Evidence that exogenous and endogenous fractalkine can induce spinal nociceptive facilitation in rats. Eur $J$ Neurosci20, 2294-302.

Moreira LO, Zamboni DS, 2012. NOD1 and NOD2 Signaling in Infection and Inflammation. Front Immunol3, 328.

Natsuka M, Uehara A, Yang S, Echigo S, Takada H, 2008. A polymer-type watersoluble peptidoglycan exhibited both Toll-like receptor 2- and NOD2-agonistic activities, resulting in synergistic activation of human monocytic cells. Innate Immun 14, 298-308.

Nguyen MD, Julien JP, Rivest S, 2002. Innate immunity: the missing link in neuroprotection and neurodegeneration? Nat Rev Neurosci3, 216-27.

Nicotra L, Loram LC, Watkins LR, Hutchinson MR, 2012. Toll-like receptors in chronic pain. Exp Neurol234, 316-29.

Ogura Y, Bonen DK, Inohara N, et al., 2001a. A frameshift mutation in NOD2 associated with susceptibility to Crohn's disease. Nature411, 603-6.

Ogura Y, Inohara N, Benito A, Chen FF, Yamaoka S, Nunez G, 2001b. Nod2, a Nod1/Apaf-1 family member that is restricted to monocytes and activates NF-kappaB. J Biol Chem276, 4812-8.

Ohashi K, Burkart V, Flohe S, Kolb H, 2000. Cutting edge: heat shock protein 60 is a putative endogenous ligand of the toll-like receptor-4 complex. J Immunol164, 55861.

Olson JK, Miller SD, 2004. Microglia initiate central nervous system innate and adaptive immune responses through multiple TLRs. J Immunol173, 3916-24.

Ozaktay AC, Kallakuri S, Takebayashi T, et al., 2006. Effects of interleukin-1 beta, interleukin-6, and tumor necrosis factor on sensitivity of dorsal root ganglion and peripheral receptive fields in rats. Eur Spine J15, 1529-37.

Parada CA, Tambeli CH, Cunha FQ, Ferreira SH, 2001. The major role of peripheral release of histamine and 5-hydroxytryptamine in formalin-induced nociception. Neuroscience102, 937-44.

Piehl F, Lidman O, 2001. Neuroinflammation in the rat--CNS cells and their role in the regulation of immune reactions. Immunol Rev184, 212-25. 
Prinz M, Priller J, 2014. Microglia and brain macrophages in the molecular age: from origin to neuropsychiatric disease. Nat Rev Neurosci15, 300-12.

Raghavendra V, Tanga F, Deleo JA, 2003. Inhibition of microglial activation attenuates the development but not existing hypersensitivity in a rat model of neuropathy. J Pharmacol Exp Ther306, 624-30.

Raghavendra V, Tanga FY, Deleo JA, 2004. Complete Freunds adjuvant-induced peripheral inflammation evokes glial activation and proinflammatory cytokine expression in the CNS. Eur J Neurosci20, 467-73.

Reeve AJ, Patel S, Fox A, Walker K, Urban L, 2000. Intrathecally administered endotoxin or cytokines produce allodynia, hyperalgesia and changes in spinal cord neuronal responses to nociceptive stimuli in the rat. Eur J Pain4, 247-57.

Ren K, 2010. Emerging role of astroglia in pain hypersensitivity. Jpn Dent Sci Rev46, 86.

Ren PC, Zhang Y, Zhang XD, et al., 2012. High-mobility group box 1 contributes to mechanical allodynia and spinal astrocytic activation in a mouse model of type 2 diabetes. Brain Res Bull88, 332-7.

Ribes S, Adam N, Schutze S, et al., 2012. The nucleotide-binding oligomerization domain-containing-2 ligand muramyl dipeptide enhances phagocytosis and intracellular killing of Escherichia coli K1 by Toll-like receptor agonists in microglial cells. J Neuroimmunol252, 16-23.

Richner M, Bjerrum OJ, Nykjaer A, Vaegter CB, 2011. The spared nerve injury (SNI) model of induced mechanical allodynia in mice. $J$ Vis Exp.

Romero-Sandoval A, Chai N, Nutile-Mcmenemy N, Deleo JA, 2008. A comparison of spinal Iba1 and GFAP expression in rodent models of acute and chronic pain. Brain Res1219, 116-26.

Saijo K, Crotti A, Glass CK, 2013. Regulation of microglia activation and deactivation by nuclear receptors. Glia61, 104-11.

Sandkuhler J, 2009. Models and mechanisms of hyperalgesia and allodynia. Physiol $\operatorname{Rev89,} 707-58$.

Sato T, Shikama Y, Shimauchi H, Endo Y, Takada H, 2011. Analgesic effects of chemically synthesized NOD1 and NOD2 agonists in mice. Innate Immun17, 54-9.

Sawada A, Niiyama Y, Ataka K, Nagaishi K, Yamakage M, Fujimiya M, 2014. Suppression of bone marrow-derived microglia in the amygdala improves anxiety-like behavior induced by chronic partial sciatic nerve ligation in mice. Pain155, 1762-72.

Seltzer Z, Dubner R, Shir Y, 1990. A novel behavioral model of neuropathic pain disorders produced in rats by partial sciatic nerve injury. Pain43, 205-18. 
Shields SD, Eckert WA, 3rd, Basbaum AI, 2003. Spared nerve injury model of neuropathic pain in the mouse: a behavioral and anatomic analysis. J Pain4, 465-70.

Sterka D, Jr., Marriott I, 2006. Characterization of nucleotide-binding oligomerization domain (NOD) protein expression in primary murine microglia. J Neuroimmunol179, $65-75$.

Sterka D, Jr., Rati DM, Marriott I, 2006. Functional expression of NOD2, a novel pattern recognition receptor for bacterial motifs, in primary murine astrocytes. Glia53, 322-30.

Strober W, Murray PJ, Kitani A, Watanabe T, 2006. Signalling pathways and molecular interactions of NOD1 and NOD2. Nat Rev Immunol6, 9-20.

Sweitzer SM, Colburn RW, Rutkowski M, Deleo JA, 1999. Acute peripheral inflammation induces moderate glial activation and spinal IL-1beta expression that correlates with pain behavior in the rat. Brain Res829, 209-21.

Sweitzer SM, Hickey WF, Rutkowski MD, Pahl JL, Deleo JA, 2002. Focal peripheral nerve injury induces leukocyte trafficking into the central nervous system: potential relationship to neuropathic pain. Pain100, 163-70.

Takeda K, Akira S, 2005. Toll-like receptors in innate immunity. Int Immunol17, 114.

Takeuchi O, Akira S, 2010. Pattern recognition receptors and inflammation. Cell140, 805-20.

Taktak YS, Selkirk S, Bristow AF, et al., 1991. Assay of pyrogens by interleukin-6 release from monocytic cell lines. J Pharm Pharmacol43, 578-82.

Tanga FY, Nutile-Mcmenemy N, Deleo JA, 2005. The CNS role of Toll-like receptor 4 in innate neuroimmunity and painful neuropathy. Proc Natl Acad Sci U S A102, 5856-61.

Tanga FY, Raghavendra V, Deleo JA, 2004. Quantitative real-time RT-PCR assessment of spinal microglial and astrocytic activation markers in a rat model of neuropathic pain. Neurochem Int45, 397-407.

Tawfik VL, Nutile-Mcmenemy N, Lacroix-Fralish ML, Deleo JA, 2007. Efficacy of propentofylline, a glial modulating agent, on existing mechanical allodynia following peripheral nerve injury. Brain Behav Immun21, 238-46.

Tjolsen A, Berge OG, Hunskaar S, Rosland JH, Hole K, 1992. The formalin test: an evaluation of the method. Pain51, 5-17.

Tong W, Wang W, Huang J, Ren N, Wu SX, Li YQ, 2010. Spinal high-mobility group box 1 contributes to mechanical allodynia in a rat model of bone cancer pain. Biochem Biophys Res Commun395, 572-6. 
Trang T, Beggs S, Salter MW, 2006. Purinoceptors in microglia and neuropathic pain. Pflugers Arch 452, 645-52.

Tsuda M, Inoue K, Salter MW, 2005. Neuropathic pain and spinal microglia: a big problem from molecules in "small" glia. Trends Neurosci28, 101-7.

Tsuda M, Shigemoto-Mogami Y, Koizumi S, et al., 2003. P2X4 receptors induced in spinal microglia gate tactile allodynia after nerve injury. Nature424, 778-83.

Uehara A, Fujimoto Y, Fukase K, Takada H, 2007. Various human epithelial cells express functional Toll-like receptors, NOD1 and NOD2 to produce anti-microbial peptides, but not proinflammatory cytokines. Mol Immunol44, 3100-11.

Uehara A, Sugawara Y, Kurata S, et al., 2005. Chemically synthesized pathogenassociated molecular patterns increase the expression of peptidoglycan recognition proteins via toll-like receptors, NOD1 and NOD2 in human oral epithelial cells. Cell Microbiol7, 675-86.

Uematsu S, Akira S, 2007. Toll-like receptors and Type I interferons. J Biol Chem282, 15319-23.

Vabulas RM, Ahmad-Nejad P, Ghose S, Kirschning CJ, Issels RD, Wagner H, 2002. HSP70 as endogenous stimulus of the Toll/interleukin-1 receptor signal pathway. $J$ Biol Chem277, 15107-12.

Van Heel DA, Ghosh S, Butler M, et al., 2005. Synergistic enhancement of Toll-like receptor responses by NOD1 activation. Eur J Immunol35, 2471-6.

Vieira SM, Cunha TM, Franca RF, et al., 2012. Joint NOD2/RIPK2 signaling regulates IL-17 axis and contributes to the development of experimental arthritis. $J$ Immunol188, 5116-22.

Vilhardt F, 2005. Microglia: phagocyte and glia cell. Int J Biochem Cell Biol37, 1721.

Voss E, Wehkamp J, Wehkamp K, Stange EF, Schroder JM, Harder J, 2006. NOD2/CARD15 mediates induction of the antimicrobial peptide human betadefensin-2. J Biol Chem281, 2005-11.

Walker K, Perkins M, Dray A, 1995. Kinins and kinin receptors in the nervous system. Neurochem Int 26, 1-16; discussion 7-26.

Wall PD, Gutnick M, 1974. Properties of afferent nerve impulses originating from a neuroma. Nature248, 740-3.

Wang X, Kuivaniemi H, Bonavita G, et al., 2002. CARD15 mutations in familial granulomatosis syndromes: a study of the original Blau syndrome kindred and other families with large-vessel arteritis and cranial neuropathy. Arthritis Rheum46, 3041-5. 
Watkins LR, Hutchinson MR, Johnston IN, Maier SF, 2005. Glia: novel counterregulators of opioid analgesia. Trends Neurosci28, 661-9.

Watkins LR, Hutchinson MR, Ledeboer A, Wieseler-Frank J, Milligan ED, Maier SF, 2007. Norman Cousins Lecture. Glia as the "bad guys": implications for improving clinical pain control and the clinical utility of opioids. Brain Behav Immun21, 131-46.

Watkins LR, Maier SF, 2003. Glia: a novel drug discovery target for clinical pain. Nat Rev Drug Discov2, 973-85.

Watkins LR, Milligan ED, Maier SF, 2001. Glial activation: a driving force for pathological pain. Trends Neurosci24, 450-5.

Watkins LR, Milligan ED, Maier SF, 2003. Glial proinflammatory cytokines mediate exaggerated pain states: implications for clinical pain. Adv Exp Med Biol521, 1-21.

Wieseler-Frank J, Maier SF, Watkins LR, 2004. Glial activation and pathological pain. Neurochem Int45, 389-95.

Wolfert MA, Murray TF, Boons GJ, Moore JN, 2002. The origin of the synergistic effect of muramyl dipeptide with endotoxin and peptidoglycan. J Biol Chem277, 39179-86.

Woolf CJ, 2011. Central sensitization: implications for the diagnosis and treatment of pain. Pain152, S2-15.

Woolf CJ, Mannion RJ, 1999. Neuropathic pain: aetiology, symptoms, mechanisms, and management. Lancet353, 1959-64.

Yaksh TL, Rudy TA, 1976. Analgesia mediated by a direct spinal action of narcotics. Science 192, 1357-8.

Yaksh TL, Rudy TA, 1977. Studies on the direct spinal action of narcotics in the production of analgesia in the rat. J Pharmacol Exp Ther202, 411-28.

Yeung JC, Yaksh TL, Rudy TA, 1977. Concurrent mapping of brain sites for sensitivity to the direct application of morphine and focal electrical stimulation in the production of antinociception in the rat. Pain4, 23-40.

Zhang J, Shi XQ, Echeverry S, Mogil JS, De Koninck Y, Rivest S, 2007. Expression of CCR2 in both resident and bone marrow-derived microglia plays a critical role in neuropathic pain. J Neurosci27, 12396-406.

Zheng W, Zheng X, Liu S, et al., 2012. TNFalpha and IL-1beta are mediated by both TLR4 and Nod1 pathways in the cultured HAPI cells stimulated by LPS. Biochem Biophys Res Commun420, 762-7.

Zimmermann M, 1983. Ethical guidelines for investigations of experimental pain in conscious animals. Pain16, 109-10. 
Zou W, Zhan X, Li M, et al., 2012. Identification of differentially expressed proteins in the spinal cord of neuropathic pain models with PKCgamma silence by proteomic analysis. Brain Res1440, 34-46.

\section{Legends}

Figure 1. NOD1 and NOD2 expression in spinal cord. Analysis of the NOD1 and NOD2 receptors in spinal cords of wildtype (WT) mice after SNI surgery and sham control group (Sham). On days 1, 3, 7, 10, 14 and 21 after the peripheral neuropathy, the samples were extracted. Western blotting analysis of NOD1 receptor (95kDa) (A) and NOD2 receptor $(115 \mathrm{kDa})(\mathrm{B}), \beta$-actin $(42 \mathrm{kDa})$. Data are shown as the mean \pm S.E.M. ( ${ }^{*} \mathrm{p}<0.05 ; * * \mathrm{p}<0.01$ compared to sham control group).

Figure 2. NOD1 is expressed in the spinal cord neurons after peripheral nerve injury. $\mathrm{NOD}^{-/-}$and WT mice were underwent SNI surgery or sham operated (Sham). On the 10th post-surgery, spinal cords were collected for double labeling immunofluorescence analysis. The images show immunoreactivity for neuron, through the anti-NeuN (green, left column), for NOD1 through the anti-NOD1 (red, middle column) and colocalization of the two markers (right column). The lower panel (B) shows an enlargement of a region of the dorsal horn of the spinal cord of the top panel (A). The arrow indicates double staining (yellow). The analysis was performed by confocal microscopy (Leica SP5).

Figure 3. NOD1 and NOD2, via RIPK2, contribute to the induction of mechanical allodynia after peripheral nerve injury. The susceptibility of the $\mathrm{NOD}^{-{ }^{--}}(\mathrm{A}), \mathrm{NOD}^{-{ }^{-}}$(B) and RIPK2${ }^{-/-}$(C) male mice to nerve injury-induced pain hypersensitivity was evaluated. Mechanical allodynia was assessed by measuring foot withdrawal thresholds in response to mechanical stimuli to the hind paw. The withdrawal threshold was determined using the up-down methods with a set of von Frey filaments. Data are shown as the mean \pm S.E.M. $\left(\stackrel{*}{\mathrm{p}}<0,05 ;{ }^{* *} \mathrm{p}<0,01 ; * * * \mathrm{p}\right.$ $<0,001$ when compared to WT group).

Figure 4. NOD1 and NOD2, via RIPK2, are not involved in the induction of inflammatory pain. The susceptibility of the $\mathrm{NOD}^{-/-}(\mathrm{A}), \mathrm{NOD}^{-/-}$(B) and RIPK2 $2^{-/-}$ 
(C) male mice to CFA-induced pain hypersensitivity was evaluated. Mechanical allodynia was assessed by measuring foot withdrawal thresholds in response to mechanical stimuli to the hind paw. The withdrawal threshold was determined using the up-down methods with a set of von Frey filaments. Data are shown as the mean \pm S.E.M.

Figure 5. Evaluation of thermal nociception in $\mathrm{NOD1}^{-/}$, NOD2 ${ }^{-/-}$and RIPK2 ${ }^{-/}$. (A-C) Mice were placed on the heated surface at different temperatures $\left(52^{\circ} \mathrm{C}\right.$ and $56^{\circ} \mathrm{C}$ ). The latency to a discomfort reaction (licking of the paws or jumping) in seconds was recorded. Data are shown as mean \pm S.E.M.

Figure 6. Evaluation of chemical nociception in NOD1 ${ }^{-/-}$, NOD2 $2^{-/-}$and RIPK2 ${ }^{-/-}$. (A-C) A formalin solution was injected into the hind paw plantar surface. The licking time was then clocked every 5 minutes for a total period of 50 minutes. The results are expressed as licking time(s) (left) and area under the curve (AUC) for the $1^{\text {st }}$ phase $(0-10 \mathrm{~min})$ and $2^{\text {nd }}$ phase $(10-50 \mathrm{~min})($ right $)$. Data are shown as mean \pm S.E.M.

Figure 7. NOD1 and NOD2, via RIPK2, are required for the nerve injuryinduced microglial activation. Microglia activation in the spinal cord was tested in ipsilateral dorsal horns at $3^{\text {rd }}, 7^{\text {th }}, 10^{\text {th }}$ and $14^{\text {th }}$ days after peripheral nerve injury by RT-qPCR. The mRNA of IBA-1 was normalized to the mouse GAPDH gene. Data are shown as mean \pm S.E.M. (\# $\mathrm{p}<0.05$, \#\#\# $\mathrm{p}<0.001$ as compared with sham and $* \mathrm{p}$ $<0.05 ; * * \mathrm{p}<0.01$ and $* * * \mathrm{p}<0.001$ compared to WT group).

Figure 8. NOD1 and NOD2 via RIPK2, are required for microglial activation in the spinal cord after peripheral nerve injury. WT, NOD $1^{-/-}, \mathrm{NOD} 2^{-/-}$and $\mathrm{RIPK} 2^{-/-}$ underwent SNI induction or sham operated mice (Sham). On day 10 post-surgery, spinal cords were collected for immunostaining with anti-IBA-1 antibody (green marker) (A). The lower panel (B) shows an enlargement of spinal cord dorsal horn region of the top panel (A). The analysis was performed by confocal microscopy (Leica SP5).

Figure 9. NOD1 and NOD2, via RIPK2, are required for the nerve injuryinduced astrocyte activation. Astrocyte activation in the spinal cord was tested in 
ipsilateral dorsal horns at $7^{\text {th }}$ day after peripheral nerve injury by RT-qPCR. The mRNA of GFAP was normalized to the mouse GAPDH gene. Data are shown as mean \pm S.E.M. (\#\#\# p $<0.001$ as compared with sham and $* \mathrm{p}<0.05 ; * * \mathrm{p}<0.01$ and $* * * \mathrm{p}<0.001$ compared to WT group).

Figure 10. NOD1 and NOD2, via RIPK2, are required for the nerve injuryinduced pro-inflammatory cytokines expression. The levels of IL- $1 \beta$ and TNF- $\alpha$ in the spinal cord was tested at $7^{\text {th }}$ day after peripheral nerve injury by ELISA. Data are shown as mean \pm S.E.M. (\#p $<0.05$ as compared with sham and $* \mathrm{p}<0.05$; ** $\mathrm{p}$ $<0.01$ and $* * * \mathrm{p}<0.001$ compared to WT group).

Figure 11. Expression profile of proinflammatory cytokines in microglial cell cultures stimulated with iE-DAP + LPS. (A-C) Primary microglia cells cultures were stimulated with iE-DAP $(100 \mathrm{ng} / \mathrm{mL})+$ LPS $(0,1 \mathrm{ng} / \mathrm{mL})$. After 48 hours of the stimulation, supernatants were collected for ELISA analysis by TNF- $\alpha$, IL- 6 and KC, respectively. Data are expressed as mean \pm S.E.M. $(* \mathrm{p}<0.05$ and $* * * \mathrm{P}<0.001$ when compared to the unstimulated medium).

Figure 12. Expression profile of proinflammatory cytokines in microglial cell cultures stimulated with MDP + LPS. (A-C) Primary microglia cells cultures were stimulated with MDP $(3 \mu \mathrm{g} / \mathrm{mL})+$ LPS $(0,1 \mathrm{ng} / \mathrm{mL})$. After 48 hours of the stimulation, supernatants were collected for ELISA analysis by TNF- $\alpha$, IL-6 and KC, respectively. Data are expressed as mean \pm S.E.M. ( $* \mathrm{p}<0.05$ and $* * * \mathrm{P}<0.001$ when compared to the unstimulated medium).

Figure 13. NOD1 and NOD2, via RIPK2, contribute to the P2X4 expression after induction of peripheral nerve injury. P2X4 expression in the spinal cord was tested in ipsilateral dorsal horns at $7^{\text {th }}, 10^{\text {th }}$ and $14^{\text {th }}$ days after peripheral nerve injury by RTqPCR. The mRNA of P2X4 was normalized to the mouse GAPDH gene. Data are shown as mean \pm S.E.M. (\#\#\# $\mathrm{p}<0.001$ as compared with sham and $* \mathrm{p}<0.05$; $* * \mathrm{p}$ $<0.01$ and $* * * \mathrm{p}<0.001$ compared to WT group).

Supplementary 1. NOD1 and NOD2 expression in spinal cord. Analysis of the NOD1 and NOD2 receptors in spinal cords of wildtype (WT) mice after SNI surgery 
and sham control group (Sham). On days 1, 3, 7, 10, 14 and 21 after the peripheral neuropathy, the samples were extracted. RT-PCR analysis of NOD1 mRNA expression (A) and NOD2 mRNA expression (B) relative to GAPDH expression. Data are shown as the mean \pm S.E.M. ( $*$ p $<0.05$ compared to sham control group).

\section{Supplementary 2. NOD1 and NOD2, via RIPK2, contribute to the induction of} mechanical allodynia after peripheral nerve injury. The susceptibility of the $\mathrm{NOD}^{-{ }^{-}}(\mathrm{A}), \mathrm{NOD}^{-{ }^{-}}$(B) and RIPK2${ }^{-{ }_{-}}$(C) female mice to nerve injury-induced pain hypersensitivity was evaluated. Mechanical allodynia was assessed by measuring foot withdrawal thresholds in response to mechanical stimuli to the hind paw. The withdrawal threshold was determined using the up-down methods with a set of von Frey filaments. Data are shown as the mean \pm S.E.M. $\left({ }^{*} \mathrm{p}<0,05 ;{ }^{* *} \mathrm{p}<0,01 ; * * * \mathrm{p}\right.$ $<0,001$ when compared to WT group).

Table 1. The sequences of the primers used for real-time RT-PCR

Figures

A
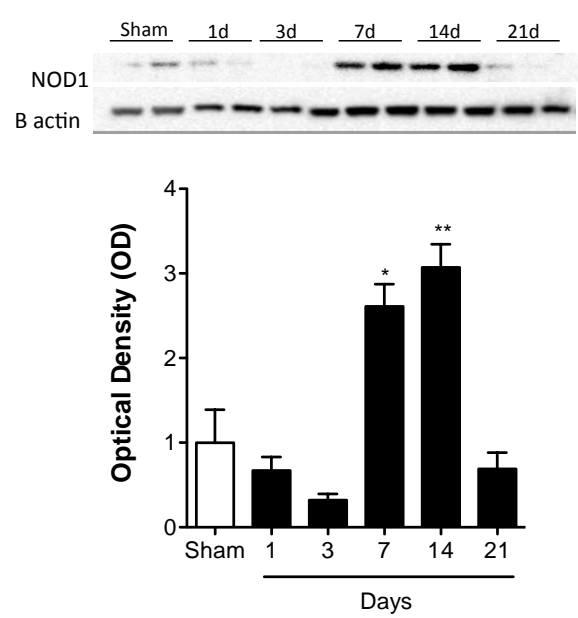

B
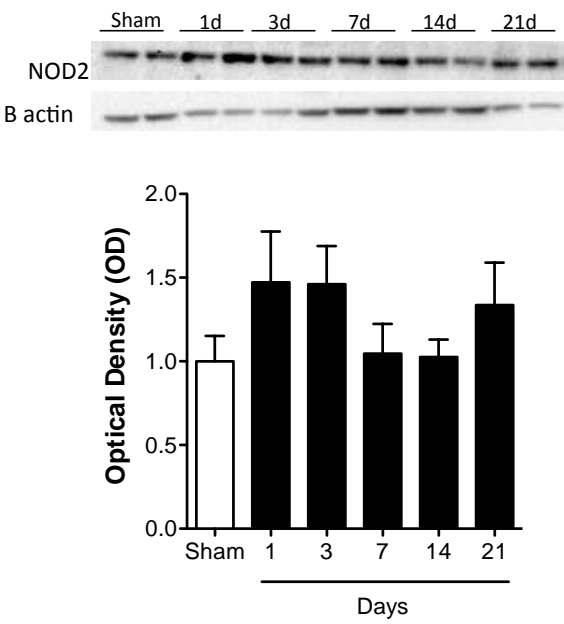

Figure 1 
A

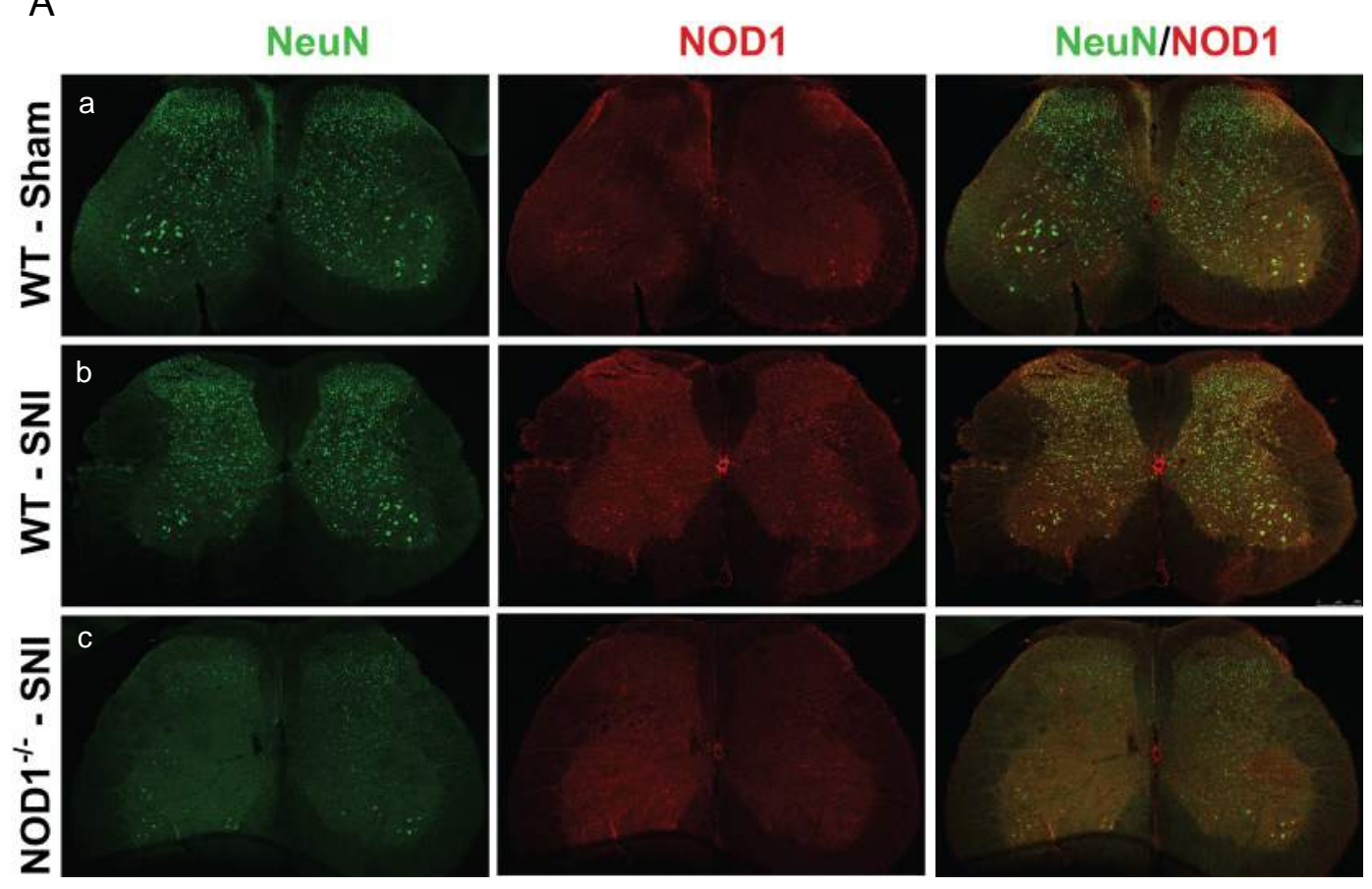

B

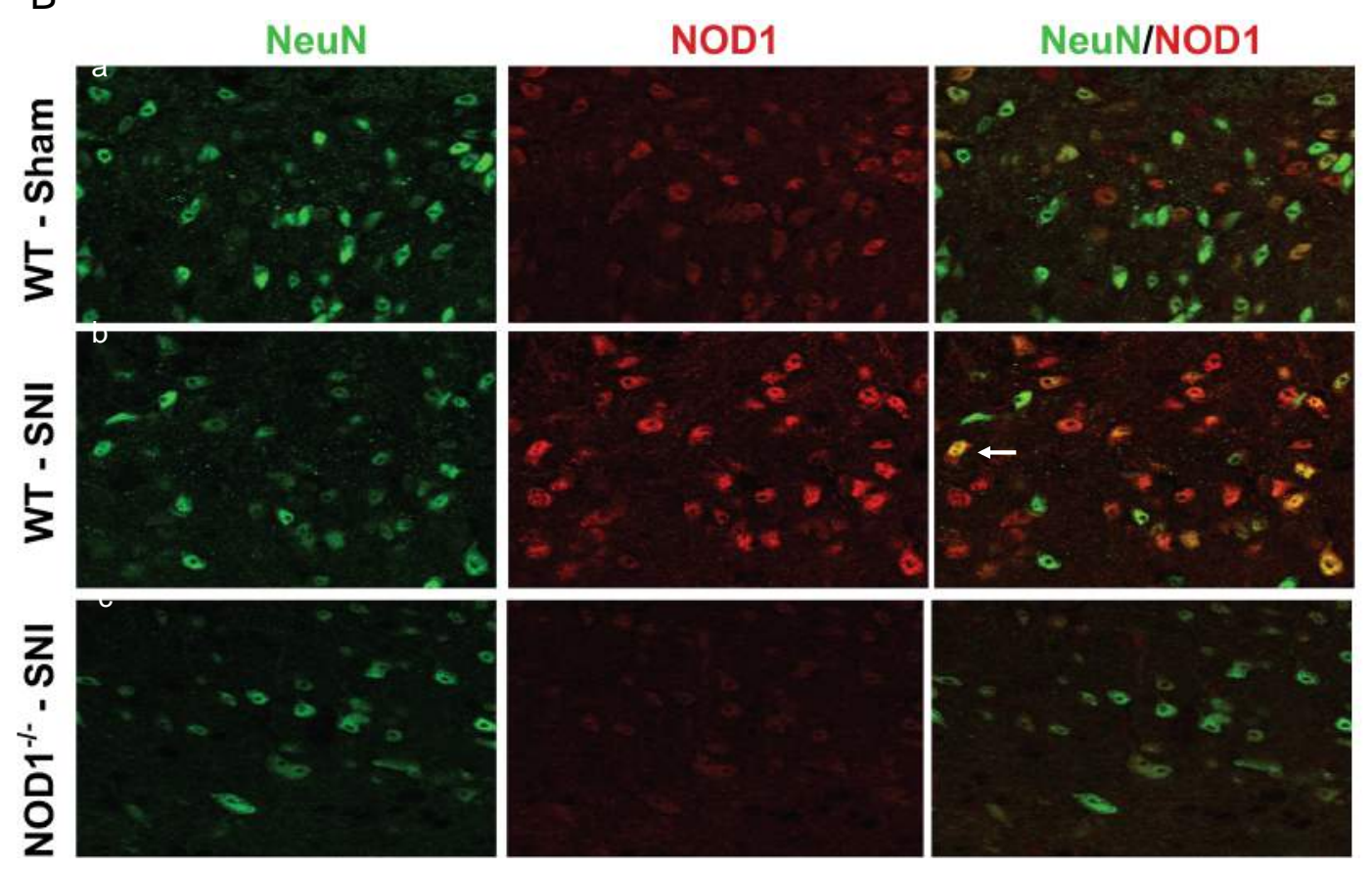

Figure 2 
A

WT
- $\mathrm{WT}-\mathrm{SHAM}$

ㅁ. NOD $1 \%$

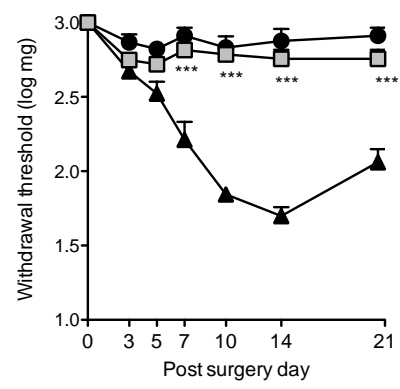

Post surgery day
B

$₫$ WT

- WT-SHAM

마 NOD2 $\%$

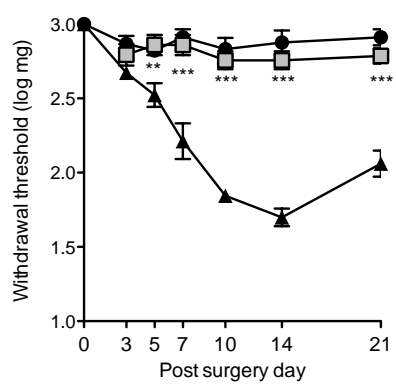

B $\prec W T-C F A$

-O- WT - Vehicle

-n NOD2 ${ }^{-1-}$ - CFA

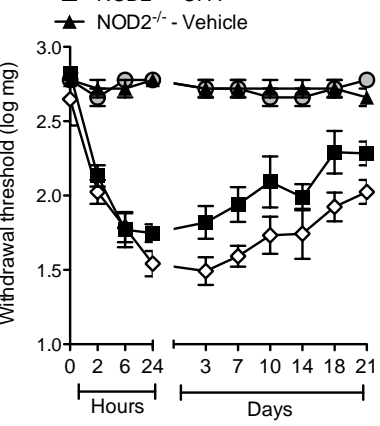

A $\prec$ WT-CFA

-O- WT - Vehicle

- NOD $1 \%$ - CFA

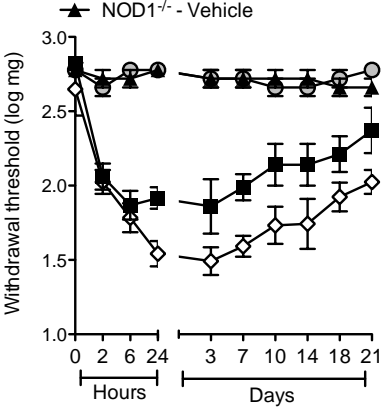

A

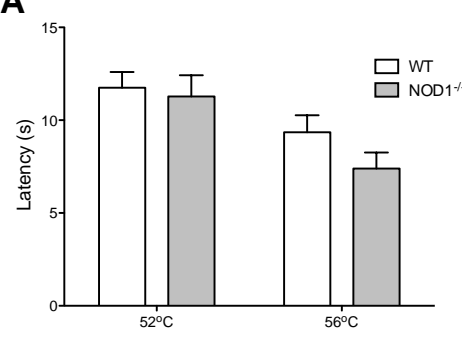

B

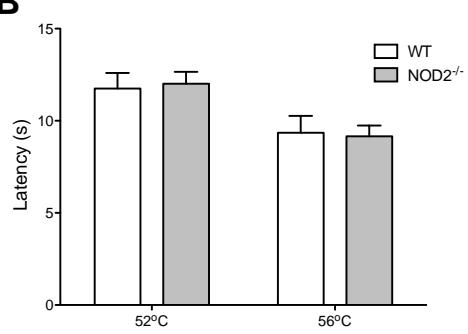

C

$\star W T$

- WT-SHAM

$\rightarrow$ RIPK2 $^{-1-}$

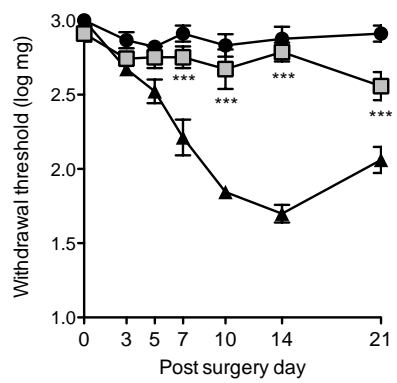

Figure 3
Figure 4

C $\diamond W T-C F A$

-O- WT - Veículo

- $\mathrm{RIPK}^{-/}$- CFA

(2)

C

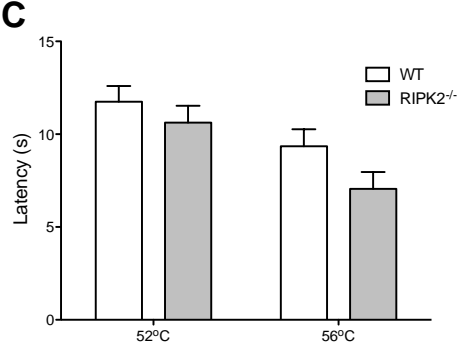

Figure 5 
A

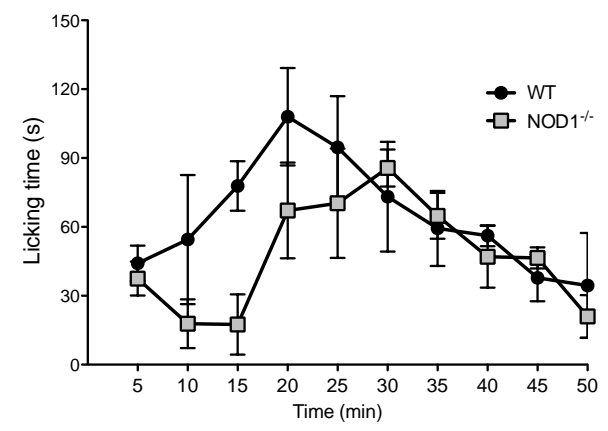

B

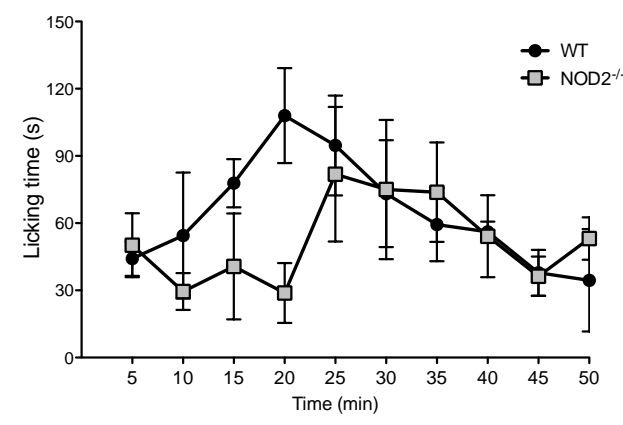

C

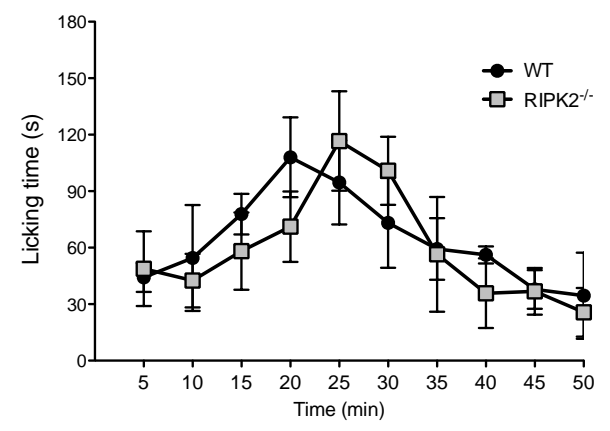

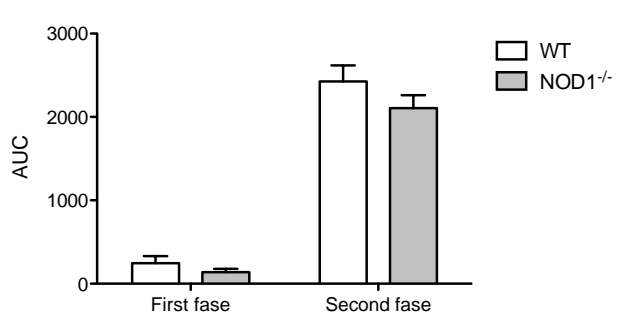
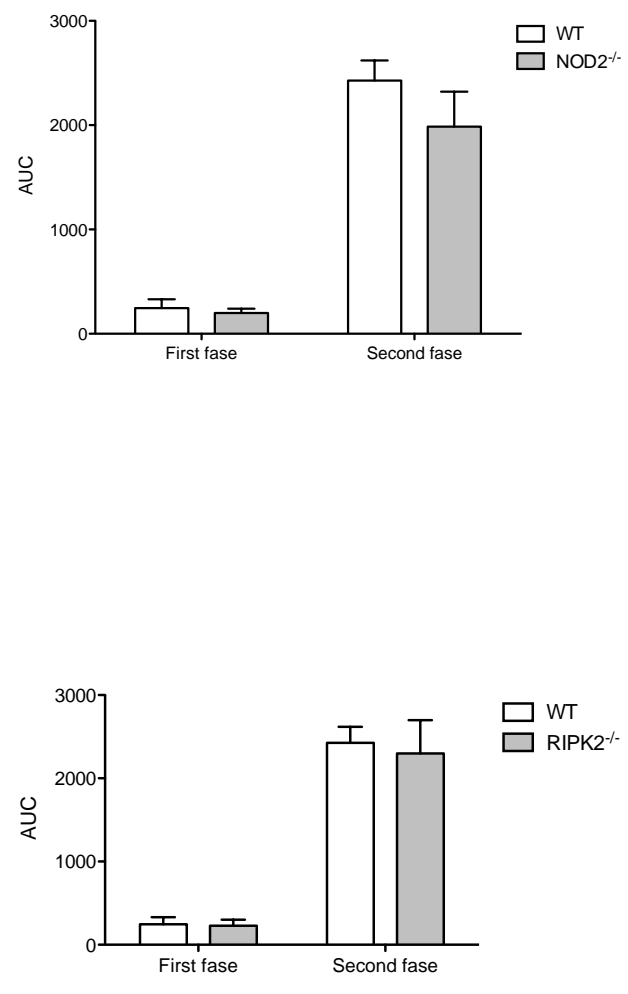

Figure 6 

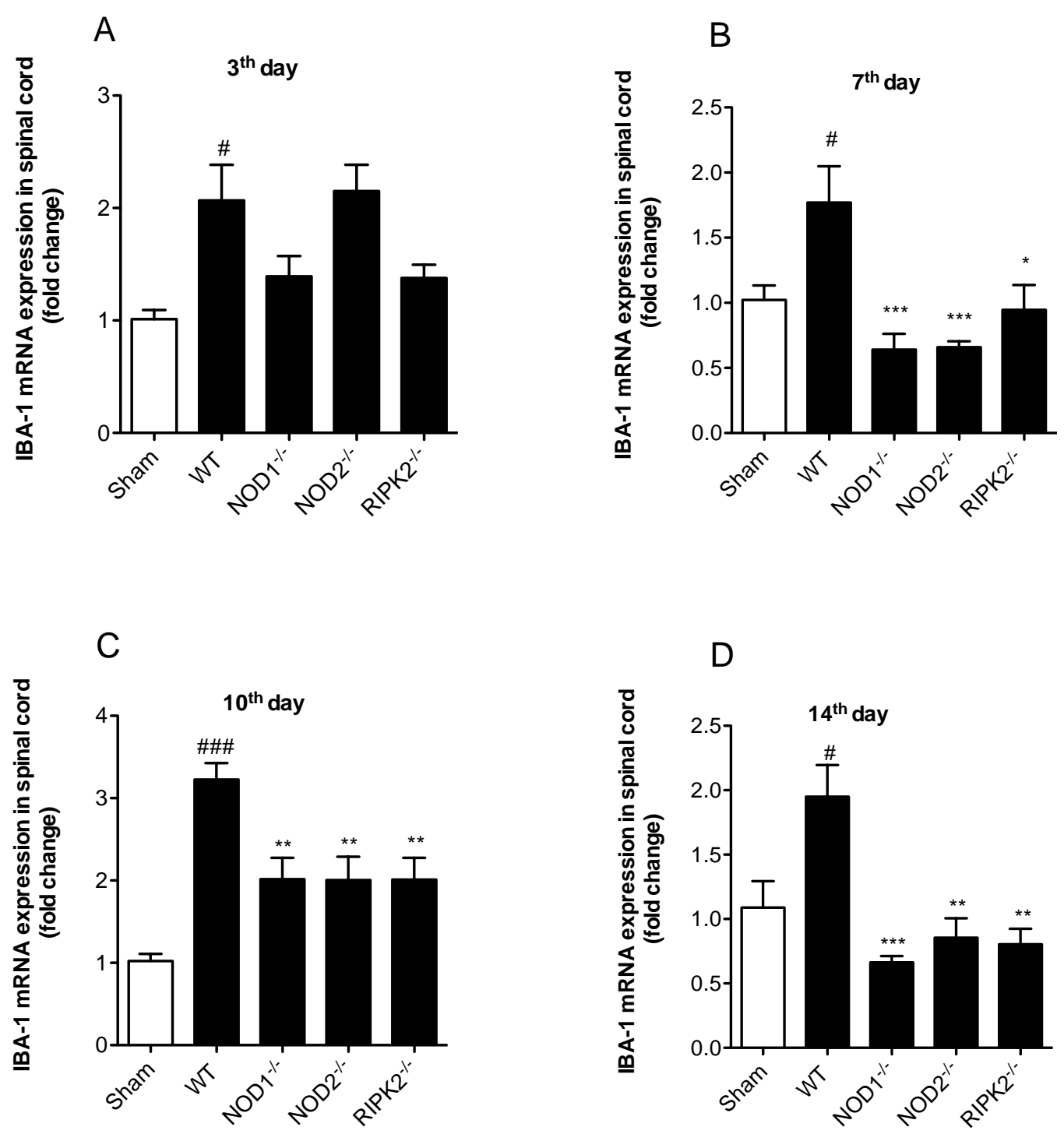

Figure 7 
A
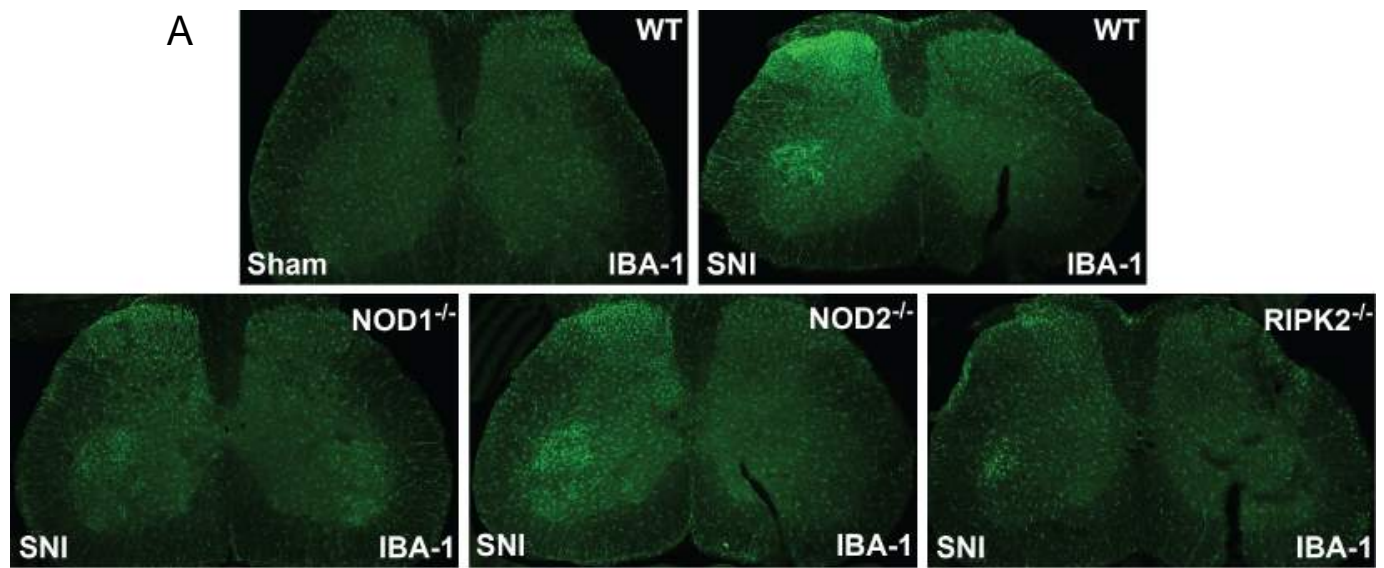

B
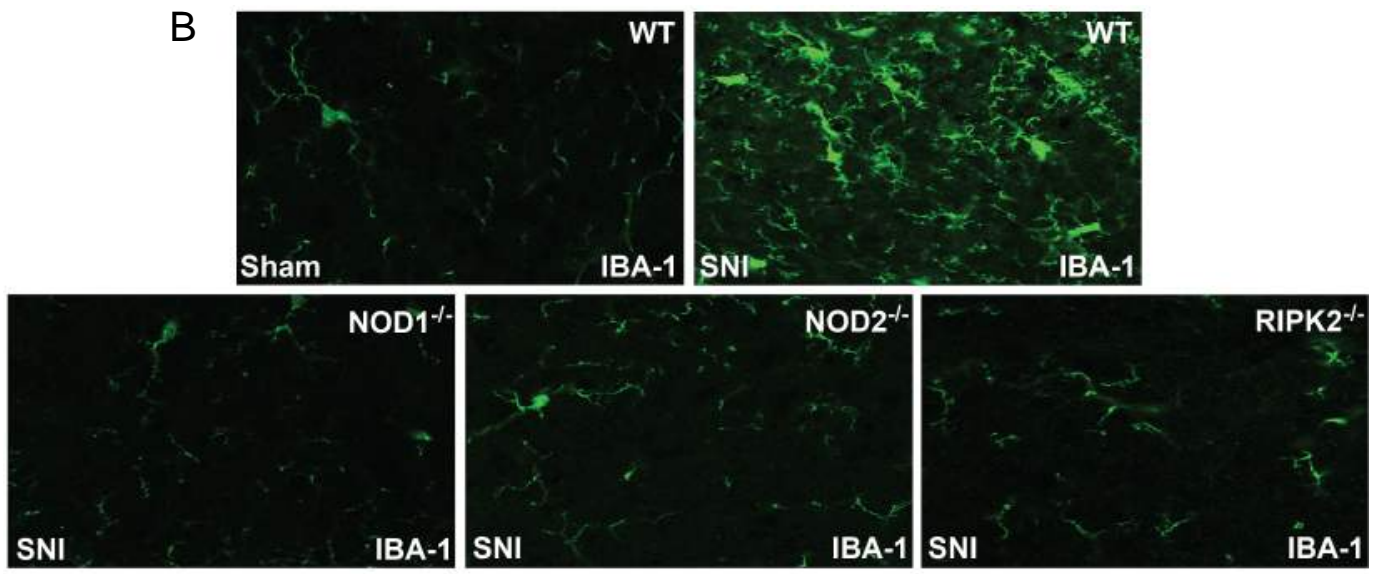

Figure 8 


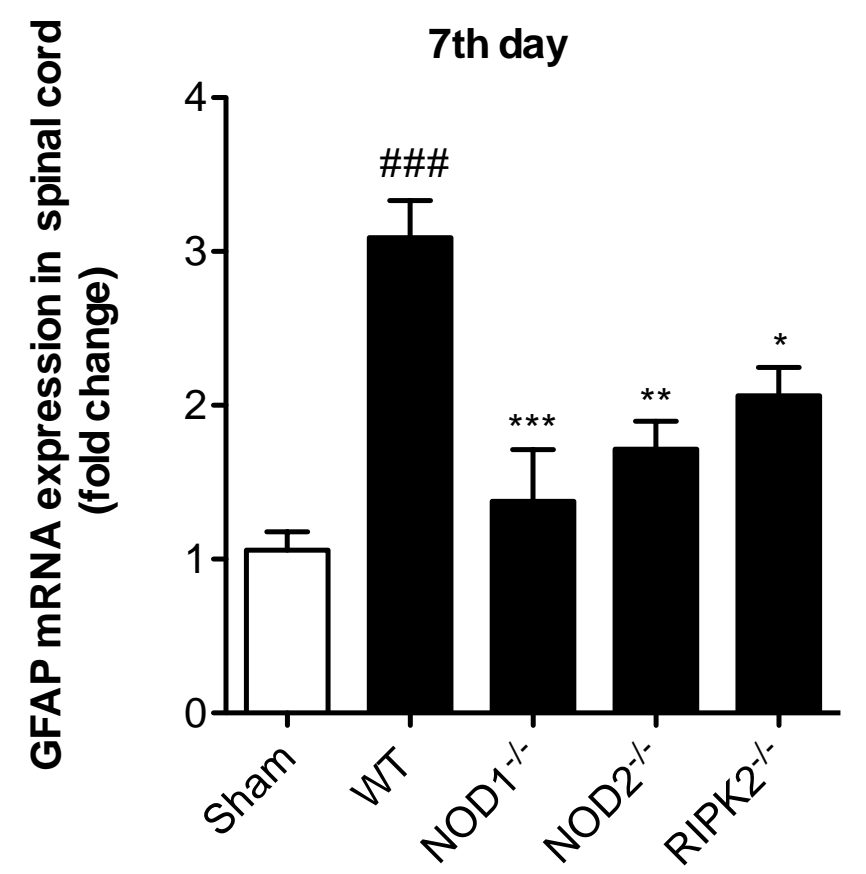

Figure 9
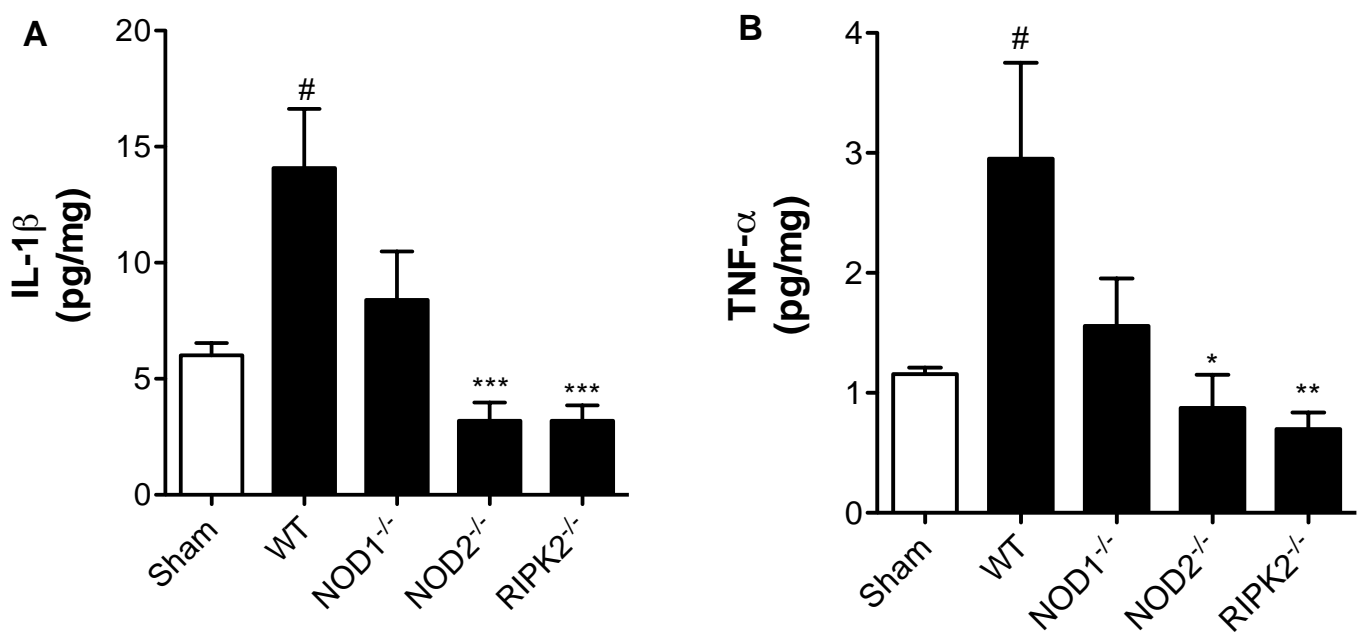

Figure 10 

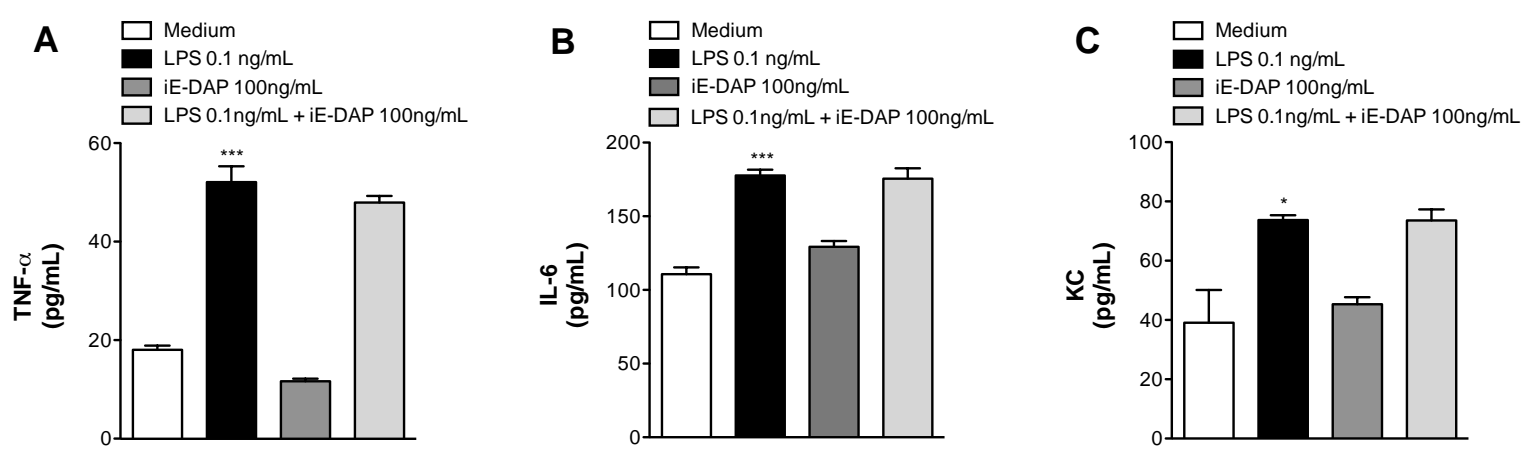

Figure 11
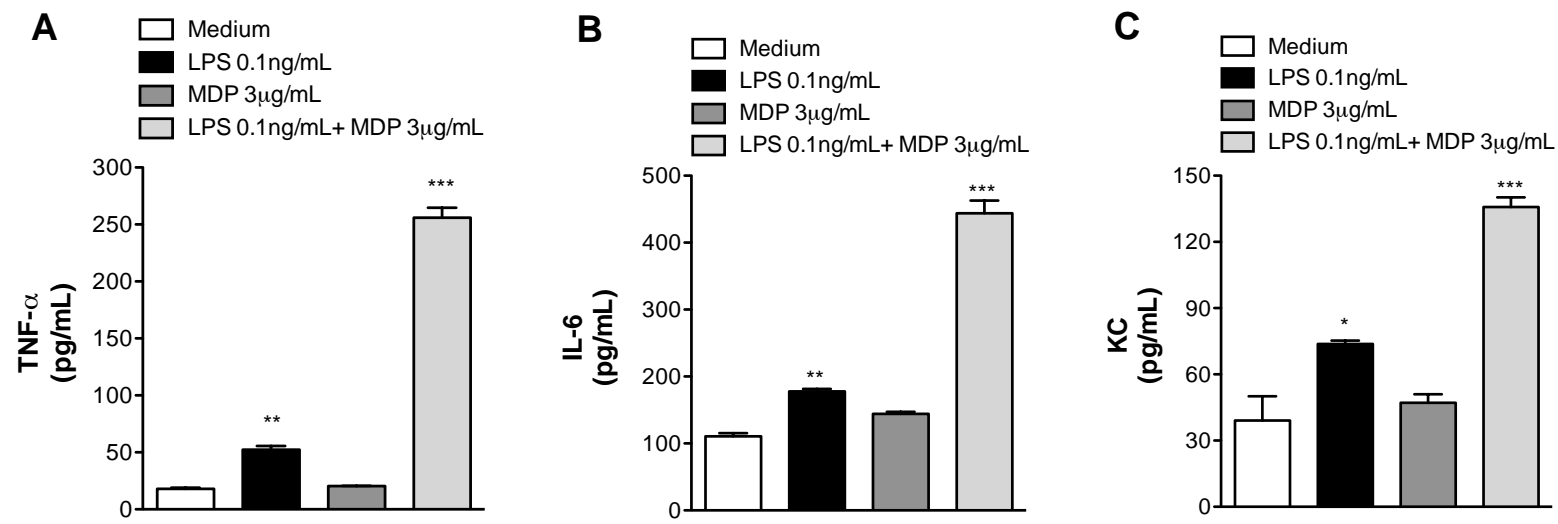

Figure 12
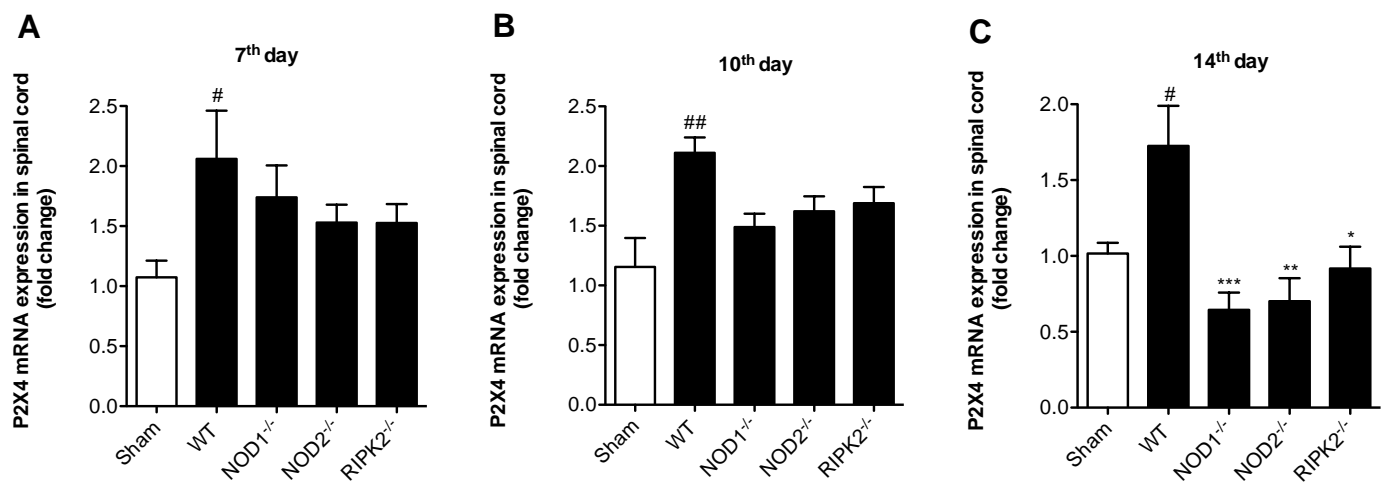

Figure 13 
A

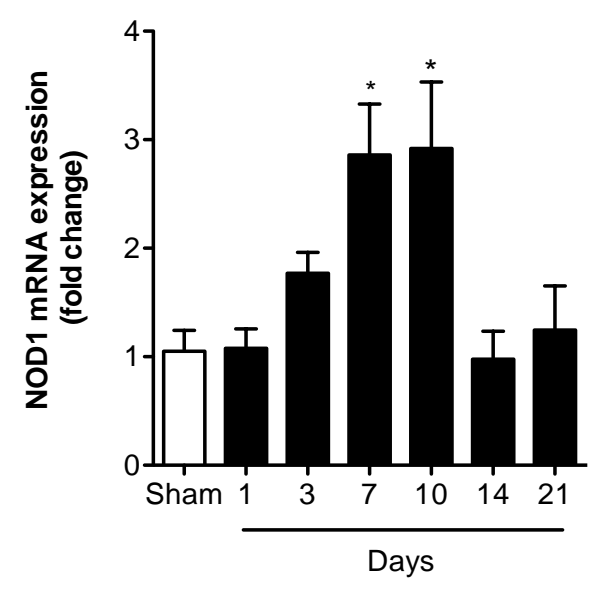

B

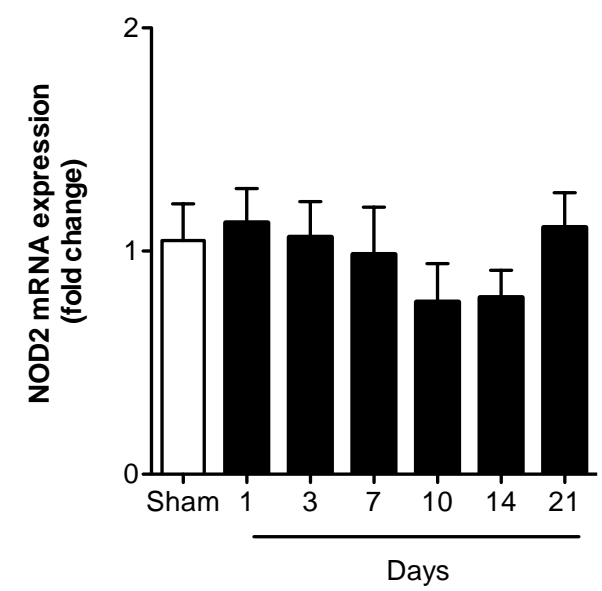

Supplementary 1
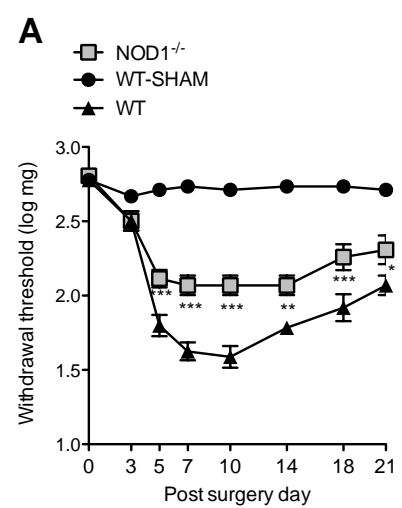

B

$\pm w T$

- WT-SHAM

마 NOD2 $\%$

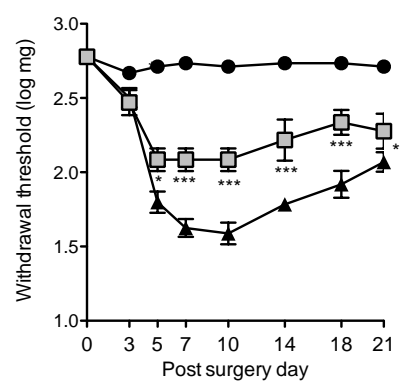

C $\pm w T$

$\rightarrow$ WT-SHAM

$\rightarrow-7$ RIPK2 $^{-/}$

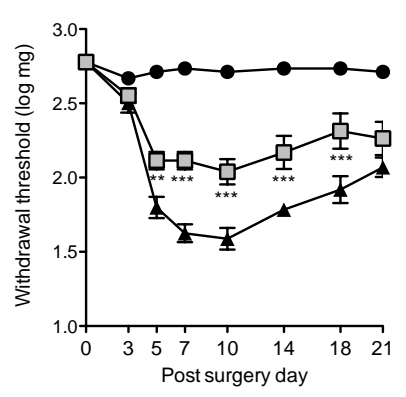

Supplementary 2

\begin{tabular}{ccc}
\hline Genes & Forward primers & Reverse primers \\
\hline GADPH & CATCTTCTTGTGCAGTGCCA & CGGCCAAATCCGTTCAC \\
P2X4 & GCGTCTGTGAAGACCTGTGA & GATTTGGCCAAGACGGAATA \\
IBA-1 & TGAGGAGCCATGAGCCAAAG & GCTTCAAGTTTGGACGGCAG \\
NOD1 & CATGATCCAGCAAAGCAATA & CCATACCCTTCTTCTCATCCAACT \\
NOD2 & AACTGTCCAACAATGGCATCAC & TTCCCTCGAAGCCAAACCT \\
GFAP & AGGGCGAAGAAAACCGCATCACC & TCTAAGGGAGAGCTGGCAGGGCT \\
\hline
\end{tabular}

Table 1 